
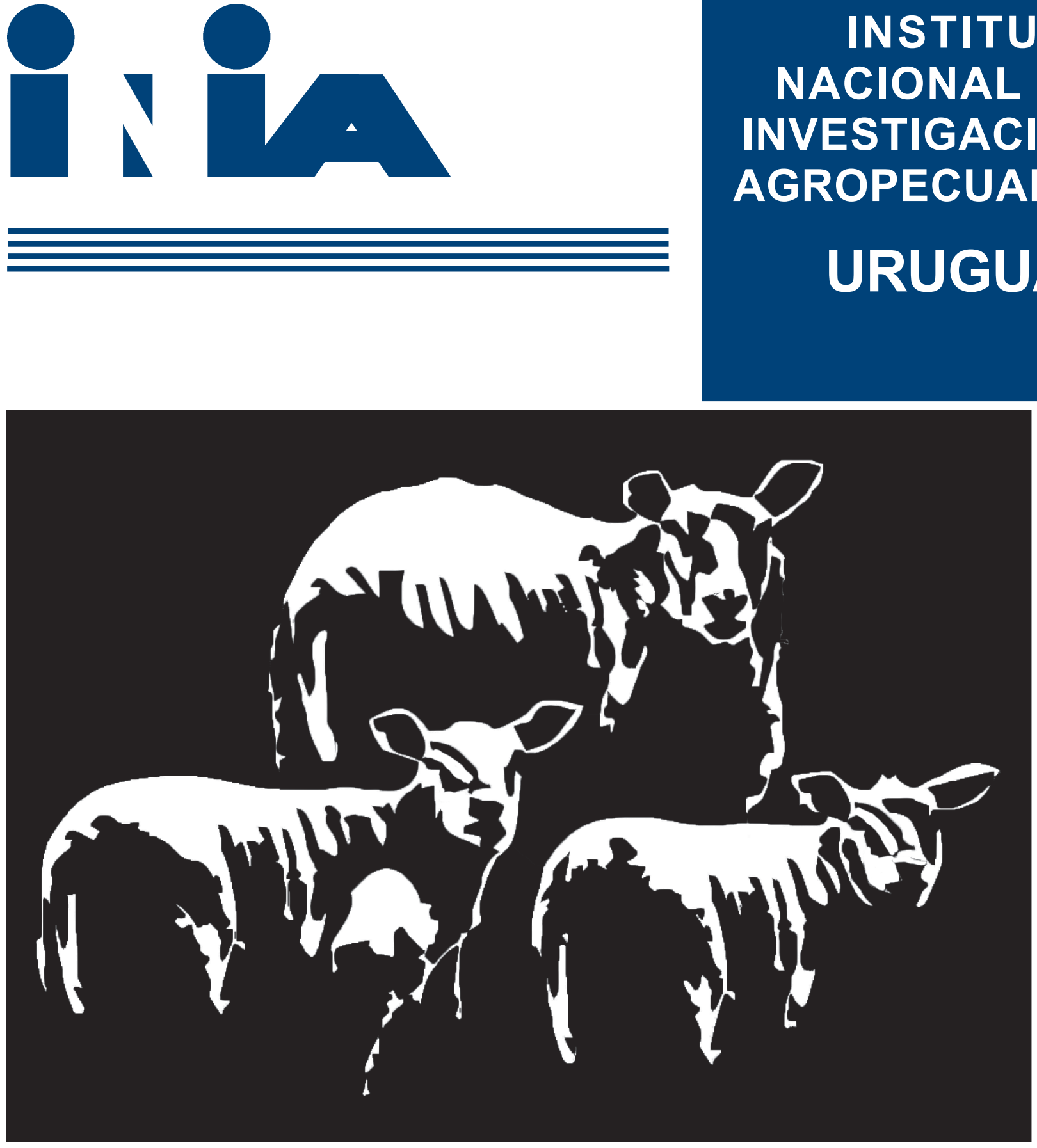

Seminario de

Actualización

Técnica: Producción de

Carne Ovina de Calidad
INSTITUTO NACIONAL DE INVESTIGACIÓN AGROPECUARIA

\section{URUGUAY}




\title{
SEMINARIO DE ACTUALIZACIÓN TÉCNICA: PRODUCCIÓN DE CARNE OVINA DE CALIDAD
}

\author{
Editores: Horacio Saravia* \\ Walter Ayala* \\ Ethel Barrios ${ }^{* * *}$
}

* Ing. Agr. M.Sc., Unidad de Comunicación y Transferencia de Tecnología. INIA Treinta y Tres.

* Ing. Agr. PhD., Director Regional INIA Treinta y Tres.

Técnica en Sistemas Intensivos de Producción Animal; Programa Nacional de Pasturas y Forrajes. INIA Treinta y Tres. 
Título: SEMINARIO DE ACTUALIZACIÓN TÉCNICA: PRODUCCIÓN DE CARNE OVINA DE CALIDAD

Autores: Horacio Saravia

Walter Ayala

Ethel Barrios

Serie Técnica $N^{\circ} 221$

(C) 2014, INIA

Editado por la Unidad de Comunicación y Transferencia de Tecnología del INIA Andes 1365, Piso 12. Montevideo - Uruguay

http://www.inia.uy

Quedan reservados todos los derechos de la presente edición. Esta publicación no se podrá reproducir total o parcialmente sin expreso consentimiento del INIA. 


\section{I nstituto Nacional de I nvestigación Agropecuaria}

\section{Integración de la Junta Directiva}

Ing. Agr., MSc., PhD. Álvaro Roel - Presidente

D.M.T.V., PhD. J osé Luis Repetto - Vicepresidente
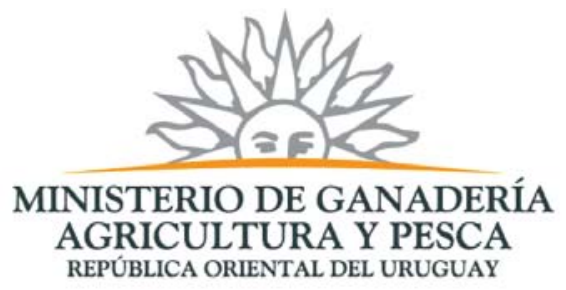

D.M.V. Álvaro Bentancur

D.M.V., MSc. Pablo Zerbino
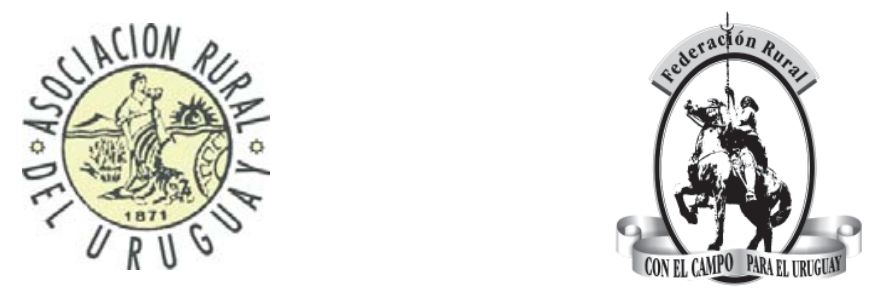

Ing. Agr. J oaquín Mangado

Ing. Agr. Pablo Gorriti
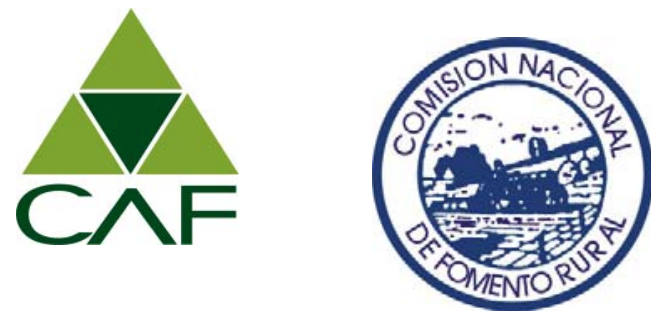



\section{CONTENIDO}

Página

PRODUCCIÓN SOSTENIBLE DE CARNE OVINA Y LAS TENDENCIAS

EN LAS PREFERENCIAS DE LOS CONSUMIDORES: COMPATIBILIDADES,

CONTRADICCIONES Y DILEMAS SIN RESOLVER 1

Fabio Mont Font-i-Furnols, Marcia del Campo, Roberto San Julián,

Gustavo Brito, Carlos Sañudo

SUPLEMENTACIÓN DE LA RECRÍA Y ENGORDE DE OVINOS SOBRE

CAMPO NATURAL 45

Lucía Piaggio

MANEJO SANITARIO DURANTE LA CRÍA Y RECRÍA DE CORDEROS 55

América Mederos Silveira

UTILIZACIÓN DE Plantago lanceolata EN LAALIMENTACIÓN DE CORDEROS

EN EL PERÍODO ESTIVAL

Ethel Barrios, Walter Ayala

UTILIZACIÓN DE VERDEOS DE VERANO EN LA ALIMENTACIÓN DE CORDEROS .... 71 Walter Ayala, Ethel Barrios, Juan Magallanes, Mauricio Paiva

ALTERNATIVAS FORRAJERAS ESTIVALES PARA LA PRODUCCIÓN DE CORDEROS: LEGUMINOSAS 79

Ethel Barrios, Walter. Ayala, Raúl Bermúdez, Juan Magallanes, Mauricio Paiva

ALTERNATIVAS FORRAJERAS ESTIVALES PARA EL ENGORDE DE

CORDEROS: BRASSICAS FORRAJERAS

Walter Ayala, Ethel Barrios

ALGUNOS FACTORES QUE INCIDEN EN LA PERFORMANCE Y

COMPORTAMIENTO DE CORDEROS DURANTE EL VERANO 105

Walter Ayala, Juan Magallanes, Mauricio Paiva

CONFINAMIENTO DE CORDEROS 113

Gianni Bianchi

USO DEL RIEGO EN PASTURAS CON DESTINO AL ENGORDE DE CORDEROS 127

Daniel Formoso, Horacio Norbis

ALTERNATIVAS GENÉTICAS PARA MEJORAR LA PRODUCCIÓN Y CALIDAD DEL

PRODUCTO CARNE OVINA

Gabriel Ciappesoni

IMPACTO PRODUCTIVO Y ECONÓMICO DEL USO DE BIOTIPOS

MATERNALES EN LAPRODUCCIÓN DE CORDEROS

Andrés Ganzábal

ESTRATEGIAS PRODUCTIVAS Y SU IMPACTO ECONÓMICO EN SISTEMAS DE PRODUCCIÓN DE CARNE OVINA DE INTENSIFICACIÓN VARIABLE

Juan Ignacio Buffa, Javier Mondelli 



\section{PROLOGO}

Esta publicación reúne información generada por la investigación nacional sobre temas relevantes respecto a la «Producción de Carne Ovina de Calidad» en el Uruguay, e involucra aportes temáticos de diferentes disciplinas que hacen a la competitividad de toda la Cadena Cárnica Ovina del Uruguay, donde se destaca la complementación y coordinación realizada por las diferentes organizaciones de investigación, educación, transferencia de tecnología y extensión ligadas al rubro ovino. Es así que resulta gratificante presentar esta publicación, que es un buen ejemplo del trabajo mancomunado entre los productores y sus gremiales, la investigación, la extensión, la academia, la industria, y las políticas públicas asociadas al rubro, por sólo mencionar algunos. Vaya pues un reconocimiento a todos los que de una manera u otra han hecho posible esta publicación y este seminario en beneficio de la competitividad del sector y su entorno.

La misma aborda aspectos que van desde la producción y el manejo, la sanidad, la alimentación, la genética, la calidad del producto, así como las contribuciones realizadas por diversas experiencias positivas en el agronegocio ovino, incluyendo aspectos de mercado y las tendencias a futuro en los consumidores de carnes desde diferentes ópticas, permitiendo reunir un importante cúmulo de información tecnológica generada a nivel del Uruguay con proyección regional, lo cual es un gran esfuerzo de síntesis y sistematización de la misma para su uso final por parte de un grupo amplio de destinatarios (productores, estudiantes, asesores, entre otros).

De este análisis resulta que existe un menú de alternativas tecnológicas amplio y aplicable a la medida de diferentes situaciones productivas y de mercado, aspecto que posiciona a los actores productivos en inmejorables condiciones para aprovechar las oportunidades que le brinda la carne ovina de calidad a toda la Cadena Cárnica Ovina del Uruguay. Las señales del mercado en muchos aspectos resultan promisorias, y a pesar que nos encontramos con un stock ovino reducido para abastecer la demanda creciente de productos de calidad y valor agregado, la información que aquí se presenta nos demuestra claramente las posibilidades que tenemos de utilizar la innovación tecnológica como una herramienta para incrementar la productividad y eficiencia con los ovinos que dispone el país. En este contexto, con menos ovinos, podemos producir más y mejor que en el pasado, donde existen oportunidades a la medida para productores a diferentes escalas productivas.

Un capítulo particular merece la consideración de estas opciones tecnológicas para la producción pecuaria familiar, donde sin duda además de destacar algunas de las ventajas mencionadas del rubro ovino para este tipo de producto de alta prioridad socioeconómica, contribuyen a la valorización del uso de mano de obra familiar y promueven la «cultura ovina» que muchos de los productores de nuestro país mantienen viva.

Los indicadores productivos y económicos que se presentan en esta publicación a partir de los sistemas de producción intensivos de carne ovina de calidad son más que estimulantes, en un marco que sin duda tiene aspectos de mejora en cuanto a la apertura de nuevos mercados, a la posibilidad de reducir la zafralidad de la oferta, aumentar en general los volúmenes y/o precio de exportación, por mencionar algunas áreas de mejora. Asimismo, se desprende que parte de los saltos cuantitativos y cualitativos a dar estarán asociados a niveles de productividad y especialización crecientes, contemplando las demandas de mercados cada vez más exigentes en cuanto a la calidad intrínseca y extrínseca de productos y procesos. 
Por último, vaya un reconocimiento en general al equipo investigadores y personal de apoyo del INIA que realizó el esfuerzo y tuvo la iniciativa de reunir los aportes generados por todos los actores para documentar la información tecnológica y de mercados que es presenta en esta publicación, y en particular a los funcionarios del INIA Treinta y Tres, que de manera silenciosa han hecho el esfuerzo para alcanzar este objetivo como anfitriones.

Ing. Agr. PhD. Walter Ayala

Director Regional, INIA Treinta y Tres

Ing. Agr. PhD. Fabio Montossi

Director Programa Nacional Carne y Lana 


\section{PRODUCCIÓN SOSTENIBLE DE CARNE OVINA Y LAS TENDENCIAS EN LAS PREFERENCIAS DE LOS CONSUMIDORES: COMPATIBILIDADES, CONTRADICCIONES Y DILEMAS SIN RESOLVER} F. Montossi ${ }^{1}$, M. Font-i-Furnols ${ }^{3}$ M. del Campo², R, San Julián² G. Brito², C. Sañudo ${ }^{4}$

\section{RESUMEN}

Existen crecientes preocupaciones por parte de la sociedad por el consumo de productos animales que hayan sido producidos y transformados en una forma sostenible. Esta tendencia influye en el consumidor al tomar la decisión de compra, particularmente en los países desarrollados. Por otro lado, en los próximos años, la presión por aumentar el volumen y la eficiencia de la producción de carne será mucho mayor para hacer frente a la demanda insatisfecha prevista. Al menos en parte, las tecnologías actuales y futuras podrían contribuir a resolver este desafío. Sin embargo, el uso de algunas de estas tecnologías podría tener un efecto negativo sobre las preferencias de los consumidores. En nuestra sociedad aún no hay consenso sobre este dilema. El objetivo de este trabajo es examinar la evidencia científica relacionada con estos temas, analizando y discutiendo el efecto de algunos de los factores extrínsecos e intrínsecos relacionados con la producción de carne ovina y en particular aquellos que podría afectar la aceptabilidad de la carne de cordero por parte de los consumidores.

Palabras clave: sostenibilidad, carne ovina, percepciones de los consumidores

\section{INTRODUCCIÓN}

Para el año 2050, el sector agrícola tiene el desafío de aumentar la producción en más del $60 \%$ para alimentar al mundo (FAO, 2012). En este escenario, es esperable que el consumo de carne, como una fuente estratégica de proteína en la dieta humana, crezca sustancialmente. La demanda proyectada demuestra que la posición de liderazgo será tomada por la carne de pollo y cerdo, seguida por la carne de bovinos y ovinos, respectivamente. Las exportaciones mundiales de carne crecerán en 19\% para el año 2021, impulsadas principalmente por carne de pollo, donde la oferta y demanda provienen principalmente de América del Norte/Sur y países exportadores de petróleo de Asia/América Latina, respectivamente. En particular, el crecimiento esperado en la producción y consumo de carne ovina ( $22 \%$ en volumen; $4 \%$ en el precio en términos reales) entre

\footnotetext{
${ }_{1}^{1}$ Director del Programa Nacional de Carne y Lana, INIA Tacuarembó, Ruta 5, km 386, Tacuarembó, Uruguay. ${ }^{2}$ Programa Nacional de Carne y Lana, INIA Tacuarembó, Ruta 5, km 386, Tacuarembó, Uruguay.

${ }^{3}$ Tecnología de los alimentos-IRTA, Granja campos Armet, 17121 Monells (Girona), España.

${ }^{4}$ Departamento de animales de producción y ciencia de los alimentos, Universidad de Zaragoza, C/Miguel Servet, 177, 50013 Zaragoza, España.
} 
2009-11 y 2021, será impulsado, en su mayoría, por los países en desarrollo.

Después de la reducción en el suministro global de carne ovina, en todo el mundo durante las últimas décadas, Rowe (2010) destaca que esa cuota de mercado de carne ovina será recuperada, asociada a incentivos de precios en comparación con otras carnes. Se ampliarán los mercados importadores tradicionales (por por ejemplo, Unión Europea y Estados Unidos) y por el aumento de la demanda de los países en desarrollo por un crecimiento en los ingresos de sus habitantes, tales como China, Arabia Saudita, Jordania, Emiratos Árabes Unidos, India, Turquía y Qatar (FAO, 2012).

La FAO (2012) menciona que en algunos países, dicha ampliación de la demanda podría promover aumentos en la productividad mediante el uso de la mejora genética y terminación de corderos con alimentación en base a granos. Nueva Zelanda y Australia son dos posibles candidatos para que aprovechen esta oportunidad de mercado. Sin embargo, en ambos países, la orientación de la producción está dominada por los sistemas de producción de tipo pastoril (Bray y GonzálezMacuer, 2010; Cottle, 2010), y el uso del feedlot está restringido a Australia (sólo el $14 \%$ del total de corderos sacrificados proviene de corrales de engorde) para abastecer principalmente el nicho del mercado de cordero de Estados Unidos. Rowe (2010) plantea que la carne ovina no puede competir con las carnes de pollo o de cerdo en volumen o en precio, por lo tanto, la alternativa es concentrarse más en la diferenciación del producto, basado en su calidad y consistencia.

Para los próximos 50 años, no existen dudas que la investigación e innovación jugarán un rol clave en el aumento de la productividad alimentaria. De modo que, básicamente, parecería que la producción ovina tendrá que afrontar dos desafíos principales al mismo tiempo: a) aumentar la producción y eficiencia, contemplando la diferenciación de producto, agregando valor y consistencia y b) aumentar la velocidad de los logros de la tecnología y la adopción para poder competir con éxito en el mercado con las otras carnes alternativas. Esta no es una competencia fácil dado el tamaño y tipo de negocio y de inversión de capital de las industrias de carnes de pollo, vacuna y cerdo. Por otra parte, esto tendrá que hacerse sin disminuir la calidad sensorial de la carne ovina.

Desde el punto de vista del consumidor, hay una creciente preocupación sobre la sostenibilidad de la intensificación de las cadenas de producción y sus posibles daños sobre el medio ambiente, salud humana y bienestar animal. En algunos segmentos de consumidores, los factores extrínsecos (por por ejemplo: origen del producto, las prácticas de producción general, bienestar animal, los valores sociales y religiosos, cambio climático, la contaminación del agua y el aire y la salud humana) parecen ser factores claves en las decisiones de compra del consumidor (Font i Furnols et al., 2006, 2009; Garnier, Claude y Plastow, 2003; Grunert, 2006; Saunders et al., 2010; Tilman et al., 2002; Troy y Kerry, 2010).

La necesidad de una agricultura más global y sostenible estuvo fuertemente dirigida en el pasado, pero debería ser aplicado específicamente a los valores y limitaciones locales en las diferentes regiones del mundo (Tilman et al., 2002).

El debate sobre la sostenibilidad de la intensificación de los sistemas de producción animal y las percepciones de los consumidores relacionadas con este tema, está abierto. En este artículo se discuten las posibles compatibilidades, contradicciones y problemas sin resolver relacionados con este dilema, y particularmente aplicados a la carne ovina.

\section{SISTEMAS DE PRODUCCIÓN DE CARNE OVINA: INTENSIFICACIÓN, TECNOLOGÍAS DE INVESTIGACIÓN, INNOVACIONES Y TENDENCIAS}

\section{Automatización}

Desde 1990, en la mayoría de los países líderes en producción y exportación ovina como Nueva Zelanda, Australia y Uruguay, es posible observar varios cambios estruc- 
turales en la cadena cárnica ovina, tales como: a) reducciones del número total de ovinos, b) reducción o conversión de establecimientos ovejeros, particularmente los más pequeños, c) más especialización en la producción de lana y/o carne, d) intensificación y aumento de la productividad, e) sistemas de producción ovina concentrados en los suelos más marginales, f) envejecimiento de los productores y g) menor disponibilidad de mano de obra (con menor calificación) para trabajar en la ganadería ovina (Montossi et al., 2011; Morris et al., 2012).

Bajo estas limitaciones sociales, económicas y ambientales, la ovinocultura tiene que ser adaptada para ser más eficiente con menos recursos, particularmente aquellos relacionados con el medio ambiente y la disponibilidad de fuerza laboral. El uso de nuevas tecnologías más precisas y exactas, para aumentar la productividad y eficiencia con menos mano de obra/cabezas ovinas y menor uso del tiempo, están llamados a jugar un lugar importante en la futura cría ovina. El avance de la automatización y el uso de herramientas tecnológicas más precisas en la ganadería ovina es una respuesta interesante y positiva en esta dirección.

La aplicación del concepto de ganadería de precisión es un concepto relativamente nuevo aplicado a sistemas de producción de carne de vacuno y ovino. La ganadería de precisión ha sido definida y aplicada para diferentes situaciones y condiciones (Berckmans, 2004; Laca, 2009a, b; Pomar, López y Pomar, 2011; Rowe, 2006). En este sentido, dirigidas a diversas áreas de la ciencia, la producción pecuaria e industrial, algunas definiciones son citadas en la literatura de la siguiente manera:

a) «Ganadería de precisión es un enfoque de sistema de producción innovador que se basa en el uso intensivo e integrado de los avances en ciencias animal y en las nuevas tecnologías de la información y la comunicación» (Pomar et al., 2011).

b) «Ganadería de precisión es uso combinado de los conceptos de agricultura de precisión para incluir todos los componentes de los agroecosistemas particularmente los animales y las interacciones planta-animal «(Laca, 2009b).

c) «Manejo ovino de precisión (MOP) describe un sistema por el que los animales son manejados como individuos o grupos pequeños en lugar de un rebaño entero» (Morris et al., 2012).

Estos enfoques de manejo de precisión del ganado tienen diferentes grados de aplicación en situaciones comerciales, donde la propuesta del MOP de los Centros de Investigación Corporativos de la Cadena Cárnica Ovina Australiana (Australian Sheep Industry Cooperative Research Centres, CRC) es muy avanzada y actualmente aplicada a situaciones de la ovinocultura australiana (CRC, 2013a, b).

Rowe y Atkins (2006) afirman que aproximadamente el $20 \%$ del total del rebaño contribuye muy poco a la productividad y rentabilidad del productor ovejero, por lo tanto, la medición, monitoreo, y procesamiento de la performance animal para seleccionar al animal más productivo es clave para mantener la competitividad de la empresa.

Morris et al. (2012) revisaron y analizaron la aplicación de MOP para las condiciones de Australia. Este sistema de gestión se basa en el uso combinatorio de (i) tecnología de identificación por radiofrecuencia (ej.: en caravanas), (ii) equipos de monitoreo remoto y automático de medición (por ejemplo el uso de una balanza «de pesada al pasar encima de la misma» y alimentada por paneles solares, Pedigree Matchmaker, sistemas de clasificación remota, aplicados para las tecnologías de suplementación selectiva, y (iii) softwares especialmente diseñados para procesar y analizar la información de performance registrada en general o para empresas ovejeras especializadas (ej. en las cabañas). Una lista de los diferentes dispositivos, equipos y software que son utilizados actualmente por los productores aparecen listados por el Sheep CRC (2013a, b). Además, la cooperativa de agricultores españoles «Los Pastores» está usando un sistema integral de información en su clasificación de corderos y centros de engorde. Estos centros reúnen, procesan y analizan la información para mejorar la productividad y consistencia de los productos ofrecidos al 
mercado. Estos procesos han sido evaluados también en relación con el estrés generado por la logística implementada así como los efectos sobre la calidad de la carne (Miranda de la Lama et al., 2009).

Los beneficios productivos y económicos de la aplicación MOP (basado en registros individuales) fueron demostrados en:

a) el ahorro de costos y uso más eficiente del tiempo de trabajo del productor (CRC, 2013a);

b) la mejora del progreso genético ovino (Atkins, 2010),

c) la aplicación de la tecnología de clasificación remota para determinar el rendimiento individual de los ovinos a través de la suplementación en condiciones de pastoreo (Bowen et al.,2009), y

d) la mejora del rendimiento individual puede impulsar positivamente la productividad y rentabilidad de la empresa (Haig, 2010).

Además, Haigh (2010) menciona que estas tecnologías también pueden reducir el estrés animal reduciendo al mínimo el movimiento de animales y confinamiento; por lo tanto pueden mejoran el bienestar de los animales. Este efecto es particularmente importante en el contexto de las alegaciones formuladas por organizaciones de bienestar animal (por por ejemplo, People for the Ethical Treatment of Animals, PETA) sobre la obligación ética y moral de los productores de proporcionar continuo monitoreo de los animales y aplicar prácticas de ganadería adecuadas para garantizar el bienestar y la salud animal.

Morris et al. (2012) concluyen que las tecnologías MOP contribuyen a mejorar la productividad, rentabilidad y reducen preocupaciones por el bienestar de los animales de la cadena cárnica ovina australiana asociados con la reducida frecuencia de monitoreo y registros llevados a cabo por el personal de campo. Los mismos autores también mencionan que los principales factores limitantes para incrementar la adopción del MOP son: a) la inversión inicial necesaria para los productores de pequeña escala (ver rangos de costos para diferentes opciones en el Sheep CRC, 2013b) y b) las restricciones en la edad y habilidades de informática de los produc- tores para estar motivados y animarse a usar estas nuevas y más sofisticadas tecnologías.

\section{Genética}

Los productores ovejeros en el mundo generalmente se caracterizan por desarrollar su producción en sistemas extensivos, haciendo uso principalmente de pastizales naturales, a menudo localizados en áreas marginales, para producir carne, lana y leche. A medida que aumenta la población mundial, la producción de alimentos y fibras sobre tierras marginales será cada vez más importante. Por lo tanto, es probable que la cadena cárnica ovina tenga una oportunidad a este aumento de la demanda (Macfarlane y Simm, 2007; Mueller, 2008). Por ejemplo, en 2006, según FAOSTAT (2007), había alrededor de 1,1 billones de ovinos en el mundo produciendo aproximadamente 13 millones de toneladas de carne ovina.

Durante el último medio siglo, los países menos industrializados experimentaron rápidos incrementos en la producción animal a través de sistemas más intensivos, incluyendo el confinamiento a gran escala. Actualmente, estos países producen la mayor parte de la carne del mundo (Fraser, 2008).

El aumento de la productividad y la eficiencia de producción de carne de cordero es un factor clave para aumentar la competitividad de la cadena cárnica ovina. La tasa de reproducción, crecimiento de cordero y calidad de la canal tienen una gran influencia sobre el retorno económico al productor. Todas éstas características de interés económico pueden ser mejoradas a través de diferentes prácticas nutricionales y de manejo. Los cambios potenciales que podrían obtenerse por manejo y nutrición son afectados por las condiciones ambientales, particularmente bajo condiciones extensivas. Por el contrario, la mejora genética de las características que contribuyen a la producción de carne de cordero es permanente y acumulativa, rentable y sustentable (Mueller, 2003).

En general, los beneficios de explotar las complementariedades de diferentes razas y heterosis son dependientes del mérito genético de las razas puras disponibles. La 
selección dentro de las razas es más compleja que la selección entre razas (García et al., 2006). Incluso donde hay buena evidencia de la superioridad de una raza sobre otra, en promedio, hay generalmente considerable variación en las características de crecimiento y de canal dentro de las razas (Macfarlane y Simm, 2007). Entonces, hay una clara oportunidad para el mejoramiento genético de éstas características.

En las últimas décadas, se realizaron experimentos de selección para varias características de la canal en un número sustancial de países, pero especialmente en Nueva Zelanda, Australia y el Reino Unido. La mayoría de las líneas de selección de Nueva Zelanda fueron seleccionadas en forma divergente por la profundidad (vía medición por ultrasonografía) del espesor de grasa dorsal y el área del ojo del bife, ajustados por el peso vivo (Macfarlane y Simm, 2007). En la mayoría de estos experimentos, las tasas de cambio genético fueron superiores al $2 \%$ anual en el espesor de grasa dorsal (Simm, 1992, 1994). Simm y Dingwall (1989), en una investigación utilizando una majada experimental Suffolk, donde los animales fueron seleccionados durante un período de 9 años basado en un índice de selección que combina información de peso vivo (PV), espesor de grasa por ultrasonido (EGU) y profundidad del músculo por ultrasonido (PMU), demostraron claramente el valor positivo de mejoramiento genético en ovinos para carne. El objetivo de cría de este índice estaba compuesto por el peso de la canal (magra) y el peso de la canal a una edad constante. Sobre esta base, se compararon dos líneas divergentes (control y seleccionado). Las ganancias genéticas entre ambas líneas fueron superiores en el PV (+ 10\%), reducción en el EGU (-13\%), mayor para la PMU $\quad(+13 \%)$ y superior en la puntuación del índice (+18\%) a favor de la línea seleccionada (Simm et al., 2002). Respuestas similares fueron observadas por Lewis et al. (1996). También se han demostrado beneficios del uso de reproductores de índice superiores en una amplio rango de pesos de faena y ambientes nutricionales (Lewis et al., 2006).
Banks (2003) discute la evolución de la cadena cárnica del cordero australiano tipo Prime durante el período 1980-2003. La cadena cárnica ovina fue afectada negativamente durante los años ' 80 y principios de los '90 por los bajos precios de lana recibido por los productores, donde posteriormente comenzó una lenta recuperación a finales de los '90. Sin embargo, desde el año 2000, la cadena cárnica ovina ha experimentado un crecimiento excepcional, donde varios programas de desarrollo ayudaron en esta recuperación (por ejemplo, Lamb Campaign, Fresh Australian Range Lamb, y Lambplan). Después de este período, el mismo autor demostró que el mejoramiento genético en la productividad y la calidad del producto aumentó en un 4\% anual desde fines de los '90, generando un producto muy competitivo (canales de cordero pesados y magros; 18$22 \mathrm{~kg}$ ). Este éxito genético se asoció con una combinación positiva por agregado de mejoras a lo largo de la cadena cárnica ovina, incluyendo un mejor manejo a nivel del establecimiento, genética, promoción y una industria orientada al consumidor. Es posible lograr una mejora continua de las cualidades de la canal mediante la reducción del engrasamiento y una mayor musculatura (Banks y Ross, 2003), que a su vez resultará en sistemas de producción más eficientes y mayor rendimiento de carne para procesadores y minoristas. Gardner et al. (2006) afirmaron que la cadena cárnica del cordero puede implementar nuevas mejoras a través del uso estratégico e intensivo de estas herramientas genéticas.

En un programa de cría, es importante monitorear el progreso genético obtenido como una forma de comprobar si se logran los objetivos de cría o es necesario realizar ajustes. Una forma de analizar las ganancias genéticas obtenidas es visualizando la media de los valores de cría de las diferentes características evaluadas por generación, así como mediante el estudio de la dirección y velocidad del cambio en cada característica (Ciappesoni et al., 2011). En general, se considera que un progreso genético anual alrededor del 2\% sería el máximo a lograr dentro de una población cerrada que 
se concentra en la selección de una sola característica (Ciappesoni et al., 2011).

En Uruguay, el programa genético de Texel (raza terminal), está usando selección cuantitativa y genómica. De este programa, algunas estimaciones preliminares para características de la calidad de canal (canal caliente, frenched rack, pesos de pierna y delanteros, grasa intramuscular e indicador de engrasamiento de la canal) resultaron en moderadas a altas heredabilidades $\left(\mathrm{h}^{2}\right.$; osciló entre 0,3 y 0,5) (Ciappesoni et al., 2012).

En las últimas décadas, los trabajos de investigación se han centrado en formas de incorporar información molecular (marcadores en el ADN) para acelerar el progreso de los programas de mejoramiento genético. Sin embargo, muy poco de esta información ha sido incluida en los actuales programas de mejoramiento genético ovino en todo el mundo. El punto de inflexión ya ocurrió, hace un par de años, en las evaluaciones de ganado lechero en los Estados Unidos cuando se comenzó a incluir la información de un nuevo tipo de marcadores, el SNP (Single Nucleotide Polymorphisms, en español Polimorfismos de Nucleótido Simple). En el caso ovino, se encuentra disponible comercialmente un panel de marcadores («chip») que permite la evaluación de más de 54.000 SNPs en cada animal. En los últimos años, intensos trabajos de investigación genética se han dedicado a estudiar la información que puede proporcionar estos marcadores y la forma de cómo incorporarla en los programas de mejoramiento genético. En Uruguay, actualmente hay dos proyectos incluyendo esta información a los programas de mejoramiento molecular. Uno de ellos centrado en la resistencia genética a parásitos gastrointestinales en las razas Corriedale y Merino (Ciappesoni et al., 2011). Hay suficiente evidencia para demostrar que existe variación genética para resistencia a diferentes enfermedades entre razas y entre animales dentro de una misma raza. Está claro que la genética será mucho más importante en el futuro para explicar las diferencias entre los animales y sobre todo en el efecto que tienen los animales resistentes sobre la epidemiología de los parásitos (Karlsson y Greef, 2012).
Beh y Maddox (1996) concluyen que la disponibilidad de marcadores de la resistencia a los nemátodos gastrointestinales en ovinos permitirá el uso de selección asistida por marcadores para aumentar la precisión de la selección en los programas de mejora genética en forma práctica en los próximos 20 años. En paralelo, deben desarrollarse protocolos de registros, captura electrónica de datos y bases de datos para proporcionar los datos fenotípicos necesarios para favorecer el uso de las tecnologías genómicas en animales (Bishop y Morris, 2007).

\section{Sistemas de producción y carne de cordero más saludable}

La carne es una importante fuente de nutrientes en la dieta para los consumidores del mundo entero, en especialmente en los países desarrollados (Delgado, 2003) y su patrón de consumo puede ser explicado por diferentes variables (Speedy, 2003). El consumo mundial de cordero es alrededor de $2 \mathrm{~kg}$ per cápita/año (FAOSTAT, www.fao.org) con grandes variaciones entre las regiones geográficas (ej. $17 \mathrm{~kg}$ en Australasia vs $0,7 \mathrm{~kg}$ en América del Norte), entre países e incluso entre regiones dentro de un mismo país. En los países desarrollados, el consumo de carne roja ha sido motivo de estudios en enfermedades no transmisibles (ej.: cáncer y enfermedades del corazón) (McNeill y Van Elswyk, 2012). Para los consumidores de los países en desarrollo, la carne roja es un recurso alimenticio estratégico para reducir la desnutrición. En estos países, las enfermedades se relacionan con las deficiencias de nutrientes esenciales coexistiendo con otras enfermedades crónicas (Schönfeldt y Gibson, 2008). Numerosos estudios epidemiológicos asocian al consumo de carnes rojas con una imagen negativa para la salud debido a su contenido de grasa (cantidad y composición). Algunos trabajos han mostrado una correlación positiva entre la ingesta de grasas y la incidencia en cáncer de colon y de próstata (World Cancer Research Fund/American Institute for Cancer Research, 2010), sin embargo, otros (Howe et al., 1997; Hunter et al., 1996) no encontraron ninguna asociación significativa. 
La carnes de cordero y vacuno también son una fuente rica de proteínas, proporcionando $20 \mathrm{~g} / 100 \mathrm{~g}$ de carne consumida y micronutrientes necesarios (hierro, zinc, selenio y vitaminas) para la vida humana, que no están presentes en los vegetales o que tienen una baja biodisponibilidad (Biesalki, 2005). Esta condición, asociada al bajo contenido de carbohidratos de carne magra roja podría ser también beneficiosa para reducir y/o prevenir el sobrepeso, cáncer o diabetes. Se supone que el desbalance en la biodisponibilidad de micronutrientes es un problema en el segmento de mayor edad de la población mundial (Viteri y González, 2002). Williams et al. (2002) reportan, para cortes de cordero australiano, un contenido de hierro promedio de $2,2 \mathrm{mg} / 100 \mathrm{~g}$ y Campo et al., (2008) para cordero español (ternasco), niveles de hierro de 0,9 a $2,0 \mathrm{mg} / 100 \mathrm{~g}$. De esta manera, el cordero es una buena fuente de hierro considerando que $135 \mathrm{~g}$ de carne cordero magra proporciona el $25 \%$ de la ingesta diaria recomendada (Food Standards Australia y Nueva Zelanda, 2004). Sin embargo, reducir la ingesta diaria a $71 \mathrm{~g} / \mathrm{d}$ de carne roja, podría afectar cubrir los requerimientos de hierro recomendado. Por esta razón, Pethick et al. (2006) sugirieron que la cadena cárnica del cordero podría implementar programas de selección genética para aumentar el contenido de hierro en la carne. También demostraron que el contenido de hierro se correlacionó positivamente con selenio pero negativamente con el contenido de $\alpha$-tocoferol. El aporte de zinc por carne de cordero es $3,3 \mathrm{mg} / 100 \mathrm{~g}$, proporcionando un nivel adecuado de este micronutriente para una salud óptima. El consumo regular de carne roja también puede ayudar a disminuir el riesgo de consumo de insuficiente vitamina $B_{12}$, que se asocia a enfermedades cardiovasculares y apoplejía. En este sentido, Campo et al. (2008) demostraron que el cordero ternasco es una buena fuente de vitamina $B$ (niacina y riboflavina principalmente).

En los últimos años, ha aumentado la preocupación por la salud humana en relación con el consumo de grasas en carnes rojas, resultando en recomendaciones hacia un mayor consumo de ácidos grasos poli-insa- turados (AGPI), especialmente los de n-3 y al mismo tiempo se ha promovido la reducción del consumo de ácidos grasos n6 con valores óptimos de AGPI/AGS (ácidos grasos saturados) y n-6/n-3 coeficientes superiores a 0,4 e inferior a 4, respectivamente (Departamento de Salud, 1994). En la literatura se destacan algunas controversias sobre la utilidad de la relación n-6/n-3 con preocupación que los ácidos grasos poli-insaturados son esenciales para la salud humana (Givens y Gibbs, 2008), principalmente en el desarrollo infantil (Harbige, 2003). Stanley et al. (2007) sugirieron el uso de valores absolutos del n-3 y n-6 en vez de su relación. Wood et al. (2003) mencionan que algunas carnes tienen naturalmente una relación AGPI/AGS de alrededor de 0,1 y algunas carnes también tienen coeficientes $n-6 /$ n-3 superiores a 4, demostrando la necesidad de mejorar estas relaciones para producir carnes más sanas. En general, un 50\% de la grasa intramuscular de carne vacuna y de cordero está compuesto por ácidos grasos monoinsaturados (MUFA), principalmente el ácido oleico (C18: 1 c-9) y ácidos grasos poli-insaturados, predominantemente el ácido linoleico (C18: $2 \mathrm{n}$-6) y ácido $\alpha-$ linolénico (C18: 3 n-3) (McAfee et al., 2010). La relación de AGPI/AGS para corderos de distintos países y sistemas de producción variaron entre 0,19 y 0,38 , siendo el contenido para los de cadena larga (CL) n-3 PUFA (C20:5, C22:5 y C22:6) entre 0,21 y 0,60 mg/ $g$ (Díaz et al., 2005). Hay una variación en la composición de ácidos grasos asociado con la raza, sexo, edad, dieta y entre los cortes (Wood y Enser, 1997). La mayoría de los esfuerzos de investigación se han centrado en el cambio de la composición de ácidos grasos de la carne roja, desde que el aumento en la relación dietética de AGPI/AGS podría reducir el nivel de colesterol en plasma y el riesgo de enfermedades cardiovasculares.

La alimentación animal tiene una gran importancia en el cambio de composición de ácidos grasos de la carne, que influyen en la salud humana y las percepciones del consumidor sobre los patrones de alimentación (Alvarez et al., 2007; Enser et al., 1998; Font i Furnols et al., 2009; McAfee et al., 2011; 
Montossi y Sañudo, 2007a, b; Sañudo et al., 2000). En general, la ingesta de forraje fresco o conservado en rumiantes genera una deposición de grasa inferior en comparación con aquellos alimentados con granos. Esto está relacionado principalmente con la más baja concentración de energía encontrada en forrajes en comparación con concentrados, así como los mayores costos de mantenimiento de animales en pastoreo en comparación con los animales confinados en corrales de engorde. El perfil de ácidos grasos en la carne de animales de pastoreo es rico en ácidos grasos poli-insaturados, principalmente el ácido linolénico y sus derivados de cadena larga, mientras que el perfil en carne de animales alimentados con concentrados es rico en ácido linoleico y su derivado, el ácido araquidónico. Blas y Morand-Fehr (2000) han revisado las estrategias de manipulación dietética para promover mejores perfiles de ácidos grasos en depósitos de grasa de cordero, demostrando que la dieta basada en pastizales aumentó los ácidos grasos C18: 0 y C18: 3 en los tejidos de cordero. También pueden ser detectadas altas concentraciones de CL PUFA n-3 en carnes de animales alimentados a pasto en comparación con los alimentados con concentrados (Enser et al., 1998) en plasma y plaquetas de consumidores sanos que consumen esta carne (McAffee et al., 2011). Angood et al. (2008), comparando el perfil de ácidos grasos de la carne de cordero producido orgánicamente o convencionalmente en el Reino Unido y vendidos en supermercados del Reino Unido, encontraron altos niveles de ácido linolénico (C18: 3) y total PUFA n-3 y más bajo ácido linoleico (C18: 2) en carne de cordero orgánico comparado con convencional, aunque ambos sistemas de producción tuvieron un cociente n-6:n-3 favorable. Aunque estas cantidades de n-3 CL en la carne son inferiores en pescados y mariscos, contribuyen casi por igual en países como Australia, donde el consumo de carne es mayor que el pescado (Howe et al., 2006). En cualquier caso, para los seres humanos, la composición de la carne y su aporte a la dieta deben considerarse dentro del concepto de una dieta equilibrada.
El ácido linoleico conjugado (ALC) fue estudiado en carnes de rumiantes por sus propiedades anticancerígenas en trabajos de laboratorio; sin embargo, son todavía desconocidos los efectos biológicos en los seres humanos. Díaz et al. (2005) en su estudio reportaron concentraciones de ALC entre 0,40 y $1,05 \%$ en cordero de diferentes orígenes y los sistemas de producción. Debe tenerse en cuenta que la composición de ácidos grasos puede ser modificada por los procedimientos de faena y especialmente el sistema de cocción (Campo et al., 2009).

El interés por utilizar más concentrados en la dieta de cordero ha aumentado por varias razones, en muchas partes del mundo. En Europa del Norte, las estaciones de producción más cortas, alentaron la terminación de corderos para el mercado en sistemas de encierre durante todo el año. El uso de más concentrados en la dieta, aumenta la performance del cordero y la eficiencia de alimentación (Jacques et al., 2011). En este sentido, los intentos de manipular la composición de ácidos grasos de cordero con diferentes recursos locales de proteína (por ejemplo, las legumbres y tortas oleaginosas) tenían menor impacto potencialmente beneficioso para la salud humana (Turner et al., 2012). Sin embargo, el aceite de pescado en las dietas de cordero tiene un efecto importante en su composición de ácidos grasos, donde se aumentaron los ácidos grasos n-3 (ver revisión de Raes et al., 2004), aunque los niveles demasiado altos de aceite de pescado pueden causar cambios de color y sabor adversos (Wood et al., 2003).

En Australia, el uso del feedlot se limita principalmente para abastecer el nicho del mercado de cordero de Estados Unidos. Por ejemplo, en algunos Estados, como Western Australia, los feedlots de cordero han aumentado, y la mayoría de la investigación se ha concentrado en mejorar la productividad, reducir los costos de alimentación y aumentar la conversión alimenticia (Bowen et al., 2006). En Australia, se ha realizado una profunda investigación caracterizando el perfil de ácidos grasos de cordero bajo condiciones de pastoreo y manipulándolas para producir un cordero más sano (Pethick et al., 2006). 
En Uruguay, la suplementación restringida con granos para engorde de corderos en pastoreo, es una de las opciones tecnológicas disponibles para aumentar la producción y la rentabilidad de los sistemas productivos, en particular con altas dotaciones o en condiciones de cantidad y calidad de forraje restringidas (Montossi et al., 2003). Bajo condiciones restringidas de pasturas, la suplementación también mejora la calidad de canal y carne de cordero (Montossi et al., 2003,2007 ) y contribuye a aumentar la competitividad de los negocios de producción de cordero (Montossi et al., 2008). En este contexto y buscando oportunidades para mejorar la rentabilidad del cordero uruguayo y aceptabilidad de la carne de cordero en el mercado europeo, se estudiaron diferentes combinaciones de regímenes de alimentación de pasto:concentrado, sobre la composición de ácidos grasos, atributos sensoriales, aceptación y percepciones del consumidor, que han sido resumidos por Montossi y Sañudo (2007b). Estos estudios han demostrado que la inclusión de ciertas cantidades de concentrados en la dieta de corderos en pastoreo sobre pasturas mejoradas, podría mejorar la performance animal, la calidad de canal y de la carne, los atributos sensoriales y la aceptación del consumidor sin cambiar la composición de ácidos grasos en comparación con los animales alimentados con pasto. Posteriormente, estos resultados fueron confirmados por Montossi et al. (2009). Por lo tanto, es posible utilizar suplementos en base a granos de forma restringida, para promover simultáneamente la productividad del cordero, la eficiencia y la producción de carne saludable bajo condiciones de pastoreo.

Finalmente, además de la importancia de una carne más saludable para el consumidor, es también importante incluir otro concepto donde «carne roja» contribuye a la inocuidad alimentaria. Esto está relacionado con la disponibilidad de cantidades suficientes de alimentos, acceso a los recursos adecuados, estabilidad del suministro de alimentos y utilización de los alimentos en una dieta adecuada, agua potable y atención médica para alcanzar el estatus de bienestar nutricional. La producción ganadera añade a la oferta de alimentos, más allá de lo que pueden proporcionar los cultivos (FAO, 2011).

\section{Sistemas de producción y bienestar animal}

Como fue mencionado anteriormente en este artículo, los sistemas de producción ovina en el mundo varían desde muy extensivos a sistemas muy intensivos. Existen algunas restricciones de bienestar en todos ellos, pero muchos otros tienen diferente importancia dependiendo del nivel de intensificación alcanzado. Ventajas y desventajas sobre el bienestar ovino se han reportado tanto en sistemas extensivos como intensivos (Fitzpatrick et al., 2006; Sevi et al., 2009).

Bajo sistemas de producción extensiva, los animales tienen libertad para moverse dentro de un hábitat que les permite realizar mejor sus funciones fisiológicas y de comportamiento. Sin embargo, el pastoreo también puede afectar adversamente el bienestar animal, debido a las fluctuaciones estacionales de la cantidad y calidad de forraje; en consecuencia, los animales en pastoreo generalmente son sometidos a un estrés nutricional temporal (Nardone et al., 2004; Sevi et al., 2009). Por lo tanto, los animales en pastoreo en sistemas de cría extensiva pueden enfrentar un desequilibrio nutricional durante este período del año, con la alteración de la fermentación ruminal y síntesis proteica, que compromete su bienestar e influye negativamente en la productividad. Si el estrés nutricional ocurre durante la época de encarnerada, también puede reducir la fertilidad ovina (Rassu et al., 2004). Ovejas lecheras de alto rendimiento bajo condiciones semi-intensivas, también pueden experimentar desequilibrios nutricionales (Sevi et al., 2009) o en sistemas de producción intensiva donde las prácticas nutricionales y de manejo no se aplican adecuadamente. En particular, la altura de la pastura y la biomasa de hojas verdes, han sido reconocidas como los factores que juegan un papel importante en la conducta ingestiva, en el consumo de forraje y en la performance de producción de ovinos y 
caprinos (Penning et al., 1991). Ensayos de campo sugieren que una altura cerca de 60 $\mathrm{mm}$ y una masa de hojas verdes de 1500 a $2000 \mathrm{~kg} \mathrm{MS} / \mathrm{ha}$ puede mejorar la ingesta, bienestar y rendimiento ovino (Orr et al., 1990) bajo condiciones templadas de pastoreo en pasturas mejoradas.

La utilización de pasturas mejoradas y su manejo apropiado, así como la suplementación restringida con granos, no sólo aumentan la producción, calidad de la canal y carne de cordero como se mencionó anteriormente en este artículo, sino que también mejoran el bienestar de los animales. Estas, entre otras tecnologías, sirven para mitigar el estrés nutricional, y están disponibles para sistemas extensivos (automatización, mejoramiento genético, etc.).

La mortalidad de corderos tiene implicancias en la producción ovina a nivel económico y en el bienestar animal, especialmente en sistemas extensivos donde representa aproximadamente $20-25 \%$. Durante un largo tiempo se han evaluado diferentes estrategias para mejorar la sobrevivencia de corderos, incluyendo el manejo nutricional de la oveja al parto, selección de ovejas por habilidad materna mejorada y manejo a la esquila. Se pueden evitar muchas muertes mediante un cuidadoso manejo de la oveja desde la concepción al parto, y cuidado perinatal del cordero recién nacido.

Sobre la base de una serie de tecnologías mejoradas, el conocimiento y la mejora en el manejo ha llevado a la capacidad de aumentar tanto el número de corderos nacidos como el número de corderos sobrevivientes dentro de los sistemas de producción extensivos. Mejorar la nutrición durante la encarnerada (Gunn, 1983), incrementa el número potencial de corderos, donde mejorar la nutrición cerca del momento del parto aumenta la producción de calostro y la lactancia (Treacher, 1983) y permiten una mayor atención por parte del productor. Estos dos factores tendrán impactos positivos sobre las posibilidades de sobrevivencia en el período neonatal. Los efectos de la suplementación durante la preñez media y tardía han sido ampliamente estudiados en situaciones tanto intensivas como extensivas. Los vínculos entre la nutrición de la oveja y peso del cordero al nacer, y entre sucesivos pesos al nacer y sobrevivencia de corderos se han demostrado muy claramente por su efecto favorable también (Mellor, 1983). Esto además es mediado por efectos en la fisiología del cordero recién nacido que a su vez afecta la capacidad para soportar los ambientes más severos (Rowan, 1992). La calidad y cantidad del calostro, la producción de leche, afectadas por la nutrición durante la preñez (Robinson et al., 1978; Banchero et al., 2007; Banchero et al., 2009) influyen notoriamente en la sobrevivencia inmediata y posterior performance. Diferentes técnicas de esquila también han sido estudiadas con el fin de mejorar la sobrevivencia de corderos (Banchero et al., 2010; Sphor et al., 2011).

Existen buenos ejemplos donde el número de preñeces múltiples se ha aumentado. Los mellizos tienen una mayor tasa de mortalidad que los corderos únicos (Purser y Young, 1959). Es concebible que los aumentos en la tasa mellicera podrían conducir a un aumento de la mortalidad total a menos que el manejo se cambie. Una mejor nutrición, ajustada a las necesidades de la oveja mellicera, junto con el manejo al parto, deberían conducir a importantes mejoras en la sobrevivencia de corderos y probablemente también en la sobrevivencia de ovejas.

La calidad del cuidado maternal recibido por los corderos puede ser influenciado por una serie de factores. Varios factores pueden influir en las relaciones madre-hijo en ovinos (Lindsay et al., 1990). Se ha demostrado, en condiciones de cría tanto extensivas (Alexander et al., 1983) como intensivas (Poindron et al., 1984) que la conducta materna después del parto varía según la raza. Las diferencias en la forma de reaccionar entre razas también han sido observadas y relacionadas con el comportamiento maternal (Gede-Putu, 1990), incluyendo la capacidad de la madre para afrontar el estrés del parto y aislamiento de la majada (Blache y Ferguson, 2005). El uso de razas ovinas prolíficas ha sido ampliamente propulsado para aumentar la producción de corderos, y en sistemas de cría intensiva ha sido exitosa, trayendo consigo una ganancia económica. Es necesario, tener un mayor énfasis en la capacidad de los animales para adaptarse a 
un ambiente y en sus respuestas de comportamiento. Será particularmente importante, lograr el establecimiento armonioso de relaciones madre-hijo. Los animales también tendrán que estar acostumbrados a la presencia de seres humanos, incluso si los períodos de contacto sólo son cortos, porque las respuestas adversas pueden conducir al estrés. Además, la intervención humana puede influir en el comportamiento maternal y causar que las ovejas abandonen a sus crías y así dar lugar a altas tasas de mortalidad (Le Neindre et al., 1996). Se sugiere que hay conocimiento y la tecnología disponible para asegurar que la mortalidad de corderos, como un indicador del bienestar ligado a la producción y rentabilidad (Waterhouse, 1996).

La depredación es una amenaza para el bienestar de las ovejas y de la rentabilidad de la cría ovina. Las ovejas tienen muy poca habilidad para defenderse, incluso en comparación con otras especies presa como el ganado bovino. Aunque las ovejas no sean mordidas directamente o sobreviven a un ataque de depredadores, pueden morir de pánico o por las lesiones sufridas (Simmons y Ekarius, 2001). Sin embargo, el impacto de la depredación varía enormemente con la región. En Africa, Australia, las Américas y partes de Europa y Asia, los depredadores pueden ser un problema muy grave. Deberían implementarse estrategias adecuadas de prevención y control, dependiendo de cada contexto, teniendo en cuenta el bienestar de los animales y las preocupaciones del público en general y los consumidores en particular.

Muchos estudios se han centrado en la relación humano-animal, que a menudo ha sido ignorada en las prácticas de crianza común, pero tiene un impacto relevante sobre el bienestar y performance de la producción ovina. La investigación ha demostrado que las interacciones humano-animales pueden imponer algunas limitaciones sustanciales sobre el bienestar animal en las cadenas ganaderas y hay una razón fuerte para la capacitación de productores y colaboradores que no sólo apunten al conocimiento técnico, sino también apunten a las actitudes y el comportamiento personal (Hemsworth y Coleman, 1998). Cambios en los sistemas de crianza, modifican considerablemente estas relaciones. Un nivel aceptable de mansedumbre puede lograrse mediante ajustes al sistema de manejo, en particular mediante una serie programada de períodos cortos de contacto con humanos. En condiciones de cría extensiva, períodos cortos de contacto de bovinos-humanos mejoran las relaciones, particularmente si el manejo ocurre pocas semanas después del nacimiento y después del destete (Le Neindre et al., 1996). Markowitz et al. (1998) informaron que la alimentación por humanos y el manejo de corderos en los primeros 10 días de sus vidas produjo mayor afinidad hacia los seres humanos más adelante en su vida. Las ovejas también son capaces de diferenciar entre su pastor y un desconocido, hasta el punto que la presencia de su pastor tiene un efecto calmante en condiciones estresantes (Boivin et al., 1997). La educación humana y la capacitación son la inversión más valiosa para mejorar el bienestar de los animales (Hemsworth y Coleman, 1998).

La castración y el descole son procedimientos utilizados en varias especies y son de particular importancia en los estudios del bienestar. Aunque se necesita investigación adicional sobre la evaluación del dolor asociado con ambos procedimientos, existe suficiente evidencia del dolor y el malestar asociado con los diferentes métodos de castración (anillo de goma, pinza de burdizzo y a cuchillo) y también por el descole (anillo de goma, a cuchillo y hierro caliente). Por lo tanto, la legislación y recomendaciones varían según los países, pero la comunidad científica está de acuerdo que independientemente de la técnica aplicada, se debe realizar sólo cuando son necesarios, temprano en la vida animal y con el uso de analgésicos. Johnson et al. (2009) demostraron que los corderos muy jóvenes tienen una respuesta a la castración cerebro-cortical reducida en comparación con sus compañeros mayores y se ha asumido que perciben menos dolor. La práctica más común en condiciones extensivas es llevar a cabo ambos procedimientos en el mismo día (castración y descole), pero teniendo en cuenta que el estrés es aditivo, es recomendable separar estos procedimientos dolorosos. 
El método de castración con anillo de goma mantiene popularidad a pesar del hecho que es uno de los métodos más dolorosos, dependiendo de la edad del cordero. Se han realizado varios estudios para determinar las formas de reducir el dolor que acompaña a este procedimiento. El uso de anestesia epidural fue ineficaz en la reducción del dolor inducido por la castración con anillo de goma (Scott et al., 1996). Sin embargo, el uso de un anestésico local junto con el método del anillo de goma fue eficaz en la reducción del dolor (Kent et al., 1998). Estos autores también encontraron que la combinación de métodos del anillo de goma y castrador sin sangrado (burdizzo) resultó en una disminución del dolor en comparación con el método del anillo sólo. Esto fue confirmado por Thornton y Waterman-Pearson (1999) que compararon el anillo de goma y métodos combinados con la castración a cuchillo. En cuanto a la respuesta de cortisol y dolor general, el método combinado de anillo de goma y burdizzo fue el menos dañino cuando no se usó anestesia. Un anestésico local fue completamente eficaz en la eliminación de las reacciones al anillo y castración combinado, pero no para el método a cuchillo. Un anestésico general fue eficaz para el método a chuchillo. La conclusión que se desprende de estos estudios es que el uso de un método combinado es el menos estresante de los estudiados, y que puede ser mejorado con el uso de un anestésico local. Otros dos estudios examinaron los factores de manejo asociados con el anillo de goma o métodos de castración sin sangrado. En uno, Kent et al. (1999) concluyeron que el anillo de goma debe utilizarse para corderos pequeños. Cuando se utiliza con corderos de 28 a 42 días de edad, se presentaron lesiones más severas y más grandes que cuando se utiliza en corderos de dos días de edad. Una encuesta sobre problemas con el uso del castrador sin sangrado indicó que la hemorragia e infección eran comunes (Hosie et al., 1996). Se recomendó que sólo debería aplicarse castradores diseñados para usarse en corderos, donde el instrumento debe ser mantenido y almacenado adecuadamente, y que el personal que lo utiliza debería estar capacitado.
Aunque el uso de una plancha cauterizante caliente produce los menores cambios en los niveles de comportamiento y de cortisol (Graham et al., 1997), pero no es el método preferido de descole debido a la incidencia con infecciones crónicas. Así, como con la castración, otros estudios han analizado las formas de reducir el dolor asociado con la aplicación del método del anillo de goma. Combinando el anillo y burdizzo se reduce el dolor en comparación con el método del anillo de goma solo. Una inyección de un anestésico local en el sitio de anillo también es eficaz (Graham et al., 1997). Tras un estudio adicional, estos mismos investigadores concluyeron que el uso de un anestésico local, inyectado con o sin aguja, fue más efectivo en la reducción del dolor que la aplicación de la pinza de burdizzo sola seguida por el uso del anillo de goma. Los operadores deben ser capacitados y competentes.

La miasis cutánea (bichera) es una enfermedad importante del bienestar y la producción para las ovinos Merino Australiano, iniciada por la oviposición de la mosca Lucillia satira (Diptera: Calliphoridae) en los tejidos del animal (Taylor, 2012; Pared, 2012). Para muchos productores ovejeros, particularmente los de zonas pastoriles no aptas para agricultura, donde dominan los ovinos de lana Merino fino, una estrategia importante para gestionar el riesgo de miasis (en uso desde hace 80 años) ha sido la operación «mulesing» (Beveridge, 1984). El procedimiento implica la modificación quirúrgica para eliminar el exceso de piel perineal y 'arrugas' en hembras jóvenes, reduciendo la acumulación de humedad y proporcionando una continua disminución en el riesgo de miasis. La práctica del «mulesing» usualmente es acompaña por la señalada del cordero, rutina realizada para mejorar el manejo sanitario a la edad de 6 a 10 semanas (Windsor y Lomax, 2012). La presión por activistas del bienestar animal sobre los compradores internacionales de lana, con boicots y amenazas, resultó en una propuesta de la Australian Wool Innovations para cesar la práctica del «mulesing» antes de 2010 (Sneddon y Rollin, 2010). Esta propuesta resultó inalcanzable, aunque se han logrado 
avances significativos de la investigación en el manejo de la cuestión. Esto ha demostrado inalcanzable, aunque investigaciones importantes sobre alternativas a «mulesing» han ocurrido, como recientemente ha sido reportado por Fisher (2011). Un enfoque de manejo integrado de plagas para control de miasis implica descole (esquila de lana en zonas perineal antes de períodos de acumulación de humedad, tales como el parto), planificación de la esquila (antes de la actividad de aumento de la población de moscas), protección química (por aspersión o inmersión con acaricidas) y selección genética contra los factores de riesgos «arrugas» y «cascarrias». En caso necesario y por un corto a mediano plazo, hasta que las arrugas y las «cascarrias» pueden minimizarse genéticamente, muchos productores recomiendan el uso de la alteración quirúrgica para reducir la propensión a la acumulación de humedad en exceso de piel de la cola y el perineo. En la actualidad, el «mulesing» se continúa como una parte necesaria de un programa de manejo integrado para miasis en muchas majadas productoras de lana en Australia. Sin embargo, importantes modificaciones de la forma en que se haya realizado la operación, se han producido, incluyendo acreditación de contratistas para «mulesing», y lo más importante, la introducción del alivio del dolor durante este procedimiento (Windsor y Lomax, 2012).

Existen muchas alternativas para intensificar la producción ovina. Estos incluyen patios de alimentación, corrales de engorde y confinamiento. Los sistemas intensivos requieren habilidades adicionales de manejo y cuidado de animales. El ambiente, incluido el tipo de superficie y piso, altas dotaciones y el suministro de alimentos concentrados pueden crear problemas a la sanidad y bienestar animal, que pueden comprometer los animales o ampliar el efecto de cualquier problema existente. Las condiciones de manejo semi-intensivas e intensivas pueden asegurar que algunas de las necesidades de los animales son más fácilmente o más eficientemente satisfechas (ej.: los ovinos generalmente son protegidos de hambre y sed y podrían ser protegidos de condiciones climáticas extremas), y los animales viven en un ambiente muy predecible y menos motivador. El aumento de la dotación se puede asociar con restricciones en los patrones de comportamiento normal de los animales, con un aumento del riesgo en las interacciones agresivas entre los animales y un aumento del riesgo de transmisión de enfermedades infecciosas. Por lo tanto, se requiere supervisión frecuente y personal con habilidad para el manejo de los animales. En situaciones de cría semi-intensiva debe prestarse mucha atención a control del microambiente, y a la elección de las estructuras, materiales y diseño apropiados para el confinamiento, con el fin de evitar amontonamiento de animales, comportamientos anormales y agresivos, aumento de la contaminación ambiental y pobre sanidad de la ubre (Sevi et al., 2009).

El sistema de confinamiento generalmente se caracteriza por una alta densidad de carga y una prolongada acumulación de heces en galpones de ovinos y caprinos. Por lo tanto, la asignación de un espacio adecuado, manejo cuidadoso de los desechos y monitoreo escrupuloso de los factores micro-climáticos (en términos de temperatura, humedad relativa y calidad del aire) son aspectos cruciales en sistemas de confinamiento de ovinos y caprinos. En cualquier caso, es fundamental entender que el mantenimiento de las condiciones de higiene, asociado con el correcto dimensionamiento de parámetros estructurales y adopción de prácticas de manejo adecuado, lo cual es importante en cualquier tipo de sistema. Se han realizado diversos trabajos de investigación sobre estos temas. Para asignación de espacio y calidad del aire, se recomienda consultar Chiumenti (1987), Dickson y Stephenson (1979) y Loynes (1983). Para la concentración de stock, ver Sevi et al. (1999). Para espacio aéreo, consultar los trabajos de Hartung (1989), Sevi et al. (2001 y 2003a), Wathes et al. (1983). Para ventilación, consultar los estudios de Albenzio et al. (2004 y 2005), Sevi (2005) y Sevi, et al. (2002, 2003b y 2003c).

El sistema de confinamiento también puede afectar el estado nutricional de los animales. De hecho, los productores tienen que ajustar las raciones de alimentación tenien- 
do en cuenta el nivel de actividad relacionada con los diferentes sistemas de confinamiento para prevenir condiciones transitorias de estrés nutricional. Los sistemas intensivos deben trabajar con énfasis en demostrar sus ventajas en bienestar animal y en la liberación de las limitaciones más importantes asociadas a sus sistemas de producción, siempre teniendo en cuenta los resultados científicos y preocupaciones del consumidor.

Cuando se evalúa la sostenibilidad de un sistema de producción animal deben considerarse el bienestar animal y las actitudes del público hacia éste (Broom, 2010). La mejora del bienestar de los animales en producción puede lograrse a través de mejoras en uno de los tres aspectos clave de desarrollo de un establecimiento: procedimientos de manejo del ambiente animal, las actitudes del personal/ganadero o a la adaptabilidad de los animales a los ambientes de producción. Muchos diferentes tipos de mediciones sobre el bienestar animal, incluyendo la sanidad, el comportamiento, la fisiología y producción animal necesitan realizarse en forma integrada con el fin de evaluar el estado de bienestar y responder todas las preguntas relacionadas con definiciones precisas de problemas particulares y desafíos que los animales enfrentan en diferentes situaciones y sistemas de producción (del Campo, 2010). La simple extrapolación de información científica y de metodologías desarrolladas para sistemas intensivos a condiciones extensivas es incorrecta y probablemente sesgada, y debería ser considerada con especial atención por la comunidad científica.

Es importante destacar que, a lo largo de la cadena de ovina, se pueden encontrar diferencias de percepción sobre la importancia de las diferentes prácticas de manejo relacionadas con el bienestar de los animales. Por lo tanto, en un balance de temas de bienestar de corto plazo (relacionado al dolor) y largo plazo de mayor impacto económico, la comunicación entre los diferentes actores involucrados en el consumo de carne, inclu- yendo a científicos, constituye un verdadero desafío (Phillips et al., 2009).

\section{PRODUCCIÓN DE CARNE OVINA Y SU CONSUMO: SOSTENIBILIDAD, INTENSIFICACIÓN Y PREFERENCIAS DE LOS CONSUMIDORES, Y SUS CREENCIAS Y VALORES}

\section{La influencia de la religión sobre la aceptación de la carne ovina para el consumo}

La religión es un aspecto que está relacionado con la elección de los alimentos por los consumidores así como el estilo de vida, la cultura, y la dieta y su influencia en la salud humana (Nakyinsige et al., 2012). Esta elección de alimentos está también relacionada con restricciones en la oferta de alimentos o prohibiciones. El cristianismo sólo establece algunas restricciones en el consumo de alimentos durante algunos períodos de tiempo, como la Cuaresma y Pascua. Otras religiones, como el hinduismo o el budismo no permiten el consumo de carne vacuna y de cerdo, mientras que el judaísmo y el islamismo no permiten el consumo de carne de cerdo, en todos los casos, porque no es considerada una carne limpia. Además, toda la carne consumida por seguidores de la religión del judaísmo debe ser Kosher, mientras que para la religión del islamismo deben ser Halal (Dindyal y Dindyal, 2003).

La carne Halal o carne «permitida» es un atributo del producto relacionado con su naturaleza, origen y método de procesamiento y es similar a la carne orgánica o carne producida debiéndose tener en cuenta el bienestar de los animales o cuestiones de sustentabilidad (Bonne y Verbeke, 2008a) e implica que la carne debe ser permisible, legal y limpia (Agriculture y Agri-Food Canada [AAFC], 2011). 
La importancia de la religión islámica en el consumo de carne cordero puede verse, por ejemplo, durante la peregrinación (Hajj) a La Meca, donde se requiere que los participantes sacrifiquen un cordero o borrego, y esto supone un consumo anual de alrededor de 2 millones corderos o borregos (Faris, 2003), lo cual no supone necesariamente un problema de salud (Ahmed et al., 2006). Este consumo anual también aumenta porque los otros musulmanes que no pueden ir a la peregrinación deberían hacer un sacrificio en el mismo período de tiempo en cada año. Además, en algunas celebraciones, como la fiesta del sacrificio (Eidul-Adha) y el nacimiento de un nuevo bebé, se recomienda a los musulmanes sacrificar un cordero, cabra o borrego (Faris, 2003).

Los musulmanes consumen carne de cordero por motivos religiosos, pero también está presente en su dieta actual. En consecuencia, el consumo cordero es muy importante dentro de la población musulmana, que en el 2010 representó el $23,4 \%$ de la población mundial y se espera que aumente hasta un $26,4 \%$ en el 2030. Se encuentran principalmente en Asia y el Pacífico (62\%), Oriente Medio- África del Norte (16\%) y África subsahariana (15\%). También existe un 2,7\% de los musulmanes en Europa y 0,3\% en Estados Unidos (Pew Research Center Forum on Religion y Public Life, 2011).

Es importante saber la cantidad de inmigrantes musulmanes que, lejos de su país de origen, siguen las directrices religiosas en cuanto a carne Halal. Se ha divulgado que son el $75 \%$ en Estados Unidos (Hussaini, 1993) y $84 \%$ en Francia (Bergeaud-Blackler y Bonne, 2007).

En 2011, en Estados Unidos, los consumidores Halal gastaron $\$ 15$ billones en alimentos Halal y servicios conexos (Islamic Food and Nutrition Council of America IFANCA, 2012) y Francia, con la mayor población de musulmanes de Europa (Lever y Miele, 2012), tiene una mercado Halal que vale $\$ 7,6$ billones por año (AAFC, 2011). En el Reino Unido, los musulmanes constituyen sólo un $5 \%$ de la población y se estima que consumen un $20 \%$ de la carne de cordero y adulta producida (The Muslims Council of
Britain, 2013). En la Unión Europea, donde la población musulmana fue estimada en más de 44 millones de personas en 2010, el mercado potencial para los alimentos Halal está creciendo rápidamente (Lever y Miele, 2012) y, de acuerdo a esto, en Europa hay compañías con importante producción y exportación de alimentos Halal (AAFC, 2011).

Por lo tanto, el cordero producido bajo los lineamientos de Halal tiene un importante potencial en el mercado europeo y americano y por eso el mercado de alimentos Halal ha crecido rápidamente durante la última década y ahora se estima que tiene un valor anual de U\$S 632 billones en una escala global (AAFC, 2011). Además, esto sería aún más importante si se cumplen estudios que confirman que hipótesis que los jóvenes generaciones de musulmanes están más interesados en el Halal que sus padres (Bergeaud-Blackler y Evans, 2010).

Los consumidores musulmanes están preocupados por la seguridad alimentaria, la calidad, así como el cumplimiento del certificado Halal de la carne que consumen (AAFC, 2011; Bonne y Verbeke, 2008b). En Europa, existe la percepción que los productos Halal son más seguros y más éticos (AAFC, 2011) y en general, los musulmanes consumen carne Halal porque la relacionan con carne sana (Bonne et al., 2009). Sin embargo, los mismos autores distinguen entre diferentes actitudes hacia la inocuidad de la carne Halal dependiendo del grado de identidad musulmana y nivel cultural.

Es importante estudiar formas de asegurar la autenticidad Halal de la carne y de los productos cárnicos etiquetados como Halal (ver informe de Nakyinsike et al., 2012) así como por qué hay diferentes organizaciones responsables del control y certificación de productos alimenticios que siguen diferentes estándares de certificación para Halal (Lever y Miele, 2012; van der Spiegel et al., 2012). Este control, junto con la implementación de un sistema Punto de Control Crítico para Análisis de Riesgo (HACCP) para puntos de control Halal puede asegurar la calidad de dicha carne (Bonne y Verbeke, 2008a) y contribuye a reducir incertidumbre de la calidad Halal entre los consumidores (Bonne y 
Verbeke, 2008b). Sin embargo, los consumidores pueden segmentarse según sus percepciones de seguridad e inocuidad de la carne Halal, su confianza en el estado de carne Halal y control y dependiendo de su opinión de quién debe realizarlo (Bonne y Verbeke, 2008b). En general, estudios de grupos de consumidores realizados en Burdeos, Cardiff, Renaix y Estambul, mostraron que los consumidores Halal preferían comprar carne Halal en carnicerías islámicas, que son percibidas como más seguras y confiables con respecto al cumplimiento del Halal y para apoyar a la comunidad musulmana, pero en Amsterdam preferían carne Halal de supermercados porque pueden encontrar comidas preparadas (Bergeaud-Blackler y Evans, 2010). Esto puede utilizarse en estrategias de marketing para abrir el mercado de carne de cordero Halal.

\section{Animales genéticamente modificados (GM) y las actitudes del consumidor}

El nacimiento de la oveja Dolly (5 de julio de 1996) fue uno de los eventos disruptivos más notables en la historia de la ciencia. Era el primer mamífero en ser clonado de una célula somática adulta, mediante el proceso de transferencia nuclear (Wilmut et al., 1997; McLaren, 2000). Desde este evento, donde Dolly fue creada sin necesidad de células masculinas para fertilizar el óvulo y madurarlo, el mundo no ha sido el mismo y el debate del uso de GM para la producción ganadera moderna y la vida moderna sigue en marcha.

Se espera que pronto un salmón GM sea comercializado al público en general en Estados Unidos. Este será, tal vez, el primer animal GM que entre en la cadena alimentaria en todo el mundo. El mencionado evento probablemente abrirá un fuerte debate por el uso de GM para alimentar a la humanidad (Fahrenkrug et al., 2010; Váquez-Salat, et al., 2012).

El uso y la evolución de la tecnología transgénica en la producción pecuaria serán profundamente impactadas por dos novedades: 1) la capacidad de aislar y mantener células somáticas embrionarias directamente desde embriones, fetos y adultos in vivo y 2) la capacidad de utilizar estos embriones y células somáticas como donantes de núcleos para las estrategias de clonación. Estos tienen muchas ventajas que no se pueden aplicar mediante el uso de las inyecciones pro-nucleares actuales de ADN (Wheeler et al., 2003). Además, por avance de esta tecnología, se han reducido los costos de producción transgénica.

Váquez-Salat et al. (2012) destacaron que las aplicaciones más comunes de GM en animales son:

a) investigación básica para generar nuevas terapias con numerosas aplicaciones en el mercado y restringido para los trabajos de laboratorio y utilizando principalmente con roedores, conejos y cerdos,

b) xenotrasplante de célula, tejido u órganos de una especie a otra. Por ejemplo, esto será uso de cerdos GM (cercanos al genoma humano) para facilitar el trasplante de órganos en los seres humanos, con un horizonte de casi 5 años para alcanzar el mercado,

c) biorreactores para generar animales GM para producir proteínas recombinantes farmacéuticas en leche (cabras, conejos, vacas y cerdos), con dos productos comerciales ya disponibles en el mercado,

d) la productividad animal, donde la mayoría de animales $\mathrm{GM}$, se han modificado para aumentar la productividad, resistencia a enfermedades, calidad, etc. (principalmente en carne, fibra y leche), donde se está muy cercano a la generación del primer animal transgénico (salmón) que esté disponible en el mercado, y finalmente

e) industria de las mascotas, donde varios animales GM tienen desarrollo para fines de recreación humana, con un producto (pescado con gen fluorescente que briIlan en la oscuridad bajo luz ultra violeta) que se comercializa en el mercado.

Sobre la base de la revisión de aplicaciones animales GM disponibles para ser lanzados en los sectores farmacéutico y alimentario (Váquez-Salatet et al., 2012), se puede observar que sólo 1 de cada 15 rasgos 
transgénicos podrían tener aplicación directa en la cadena cárnica ovina (resistencia a enfermedades priónicas). Fahrenkrug et al. (2010) también visualizan las aplicaciones ganado GM a la producción agropecuaria, donde otra vez solo 2 en 32 aplicaciones (virus de resistencia Visna maedi y la tasa ovulatoria) podría tener uso específico para la cadena cárnica ovina. Sin embargo, otras aplicaciones GM probadas en otras especies pueden utilizarse también para los ovinos en el futuro (por ejemplo, aumentar la tasa de crecimiento, y modificar algunos aspectos de la calidad de la carne).

En todo el mundo, la modificación genética de animales y plantas transgénicas sigue siendo una cuestión controvertida. Sin embargo, varios especialistas en este campo mencionan que la resistencia pública al uso de GM será mayor en los animales que en plantas. Algunas cuestiones relacionadas con los aspectos éticos y morales de nuestra sociedad moderna han sido puestos a la consideración pública por gobiernos, grupos de protección animal y medios de comunicación contra el uso de animales GM, particularmente en la cadena alimentaria (Knight, 2009; Váquez-Salat et al., 2012).

La percepción negativa del consumidor contra el organismo genéticamente modificado (OGM) se observó principalmente en la combinación de las cuestiones ambientales, económicas, de seguridad y éticas (Knight, 2009). La mayoría de las percepciones negativas se asocian (por ejemplo: Frewer et al., 1997; Pascalev, 2003; Blasco, 2008; Tsourgiannis et al., 2011) con: a) la salud humana, b) riesgos ambientales (particularmente en el largo plazo), c) ética (por ejemplo: bienestar animal), d) salud humana (por ejemplo: alergias), e) valores culturales, $f$ ) cuestiones antinaturales e inmorales y g) razones religiosas (por ejemplo: genes de cerdo en los alimentos utilizados por la comunidad musulmana).

Entre los factores beneficiosos discutidos por los partidarios del uso de animales GM, se pueden destacar: a) soluciones tecnológicas para escasez de agua y alimentos, b) mejoras en la salud humana y animal, c) reducción del costo para producir e industrializar bienes, d) mantener o mejorar la sustentabilidad del medio ambiente, e) aumentar la productividad y la eficiencia a lo largo de la cadena alimentaria y f) promover el bienestar de los animales (por ejemplo: evitar la castración) (Nelson, 2001; Knight, 2009; Fahrenkrug et al., 2010).

Sin embargo, Blasco (2008), en una revisión de la literatura sobre la posibilidad de utilizar los animales transgénicos en la agricultura, afirmó que «se ha dicho que se trata de un campo en el que hay más opiniones sobre el posible uso y futuro de la transgénesis, que publicaciones actuales con información real de su aplicación».

Christoph et al. (2008) demostraron que los consumidores alemanes no tienen las mismas percepciones acerca de los potenciales efectos relacionadas con la utilización de animales GM en su sociedad. Por ejemplo, son más coincidentes a la utilización de animales GM para la medicina humana (por ejemplo, insulina GM para el tratamiento de la diabetes) y la producción de alimentos para mejorar la nutrición (por ejemplo, vitaminas) en los países en desarrollo. Sin embargo, en términos generales, este estudio también demostró la percepción negativa de los consumidores alemanes acerca de la aceptabilidad de la modificación genética (en animales y plantas) para la producción de alimentos. Además, incluso con la aparición de nuevos estudios que no pudieron demostrar ningún riesgo al ser humano por el uso de estos productos, algunos de los consumidores no consumirían alimentos genéticamente modificados, dado su fuerte actitud negativa contra los productos transgénicos. Esto podría reflejar la falta de confianza hacia las autoridades y sus procedimientos de control. Mucci y Hough (2003) también demostraron percepciones negativas hacia el consumo de alimentos genéticamente modificados en los consumidores argentinos, en particular asociados a potenciales riesgos humanos y ambientales, sin confianza sobre el control de estos por los organismos gubernamentales y el sector privado.

En cualquier caso, la humanidad ha consumido carne, leche, productos avícolas y así sucesivamente, incluso durante siglos, que 
incluyen millones y millones de genes (con sus respectivas mutaciones) de bovinos y no se han originado preocupaciones específicas.

Tsourgiannis et al. (2011) demostraron las percepciones negativas al consumo de alimentos GM en un grupo de consumidores de Grecia. Basándose en estos resultados, los autores sugirieron y promovieron el uso del etiquetado y certificación de alimentos libres de GM para distinguir y aumentar la competitividad de los productos locales y para ser más competitivos en este nicho de mercado contra los productos importados (convencionales). Esto es particularmente importante en la Unión Europea, donde no hay ninguna obligación de etiquetar los productos animales libres de OGM como es el caso de los vegetales. Sin embargo, Schilter y Cosntable (2002) argumentaban que la trazabilidad y etiquetado son herramientas importantes en el ámbito de regulación de alimentos GM en el mercado europeo. Sin embargo, estos autores dijeron también que, el etiquetado podría ser contraproducente, aumentando la confusión entre los consumidores sobre la seguridad de los OGM, promoviendo el aumento de aversiones sin fundamento contra ellos.

En relación con la cuestión de GM, los Estados Unidos y la Unión Europea han tenido un enfoque muy diferente en este tema en casi todos los segmentos de la cadena alimentaria (academia, gobierno, sector privado, los medios de comunicación, grupos de bienestar animal y medio ambiente y los consumidores) (Rowland, 2002; Knight, 2009; Váquez-Salat et al., 2012). Hay un largo y antagónico debate entre EEUU y UE relacionados al desarrollo, control y uso de animales modificados genéticamente por la sociedad. Esta oposición se espera que se prolongue en el tiempo. Un factor importante a considerar es el papel clave que China podría desempeñar en este dilema, particularmente teniendo en consideración el avance de esta tecnología en este país y la amplia aceptación de los alimentos genéticamente modificados entre los consumidores chinos (Zhang et al., 2010).

El destino de lo que suceda con la producción de alimentos GM, importación, ex- portación, consumo podría ser un factor importante a considerar por la cadena cárnica ovina alrededor del mundo. En este sentido, China tiene la población de ovinos más grande del mundo, mientras que EEUU y la UE están entre los cinco importadores más relevantes de los mercados de la carne ovina. La futura competitividad de la cadena cárnica ovina seguramente será modelada por este problema. El equilibrio entre los factores positivos y negativos que afectan la producción y la aceptación mundial de animales GM en la cadena cárnica ovina todavía está por verse. En cualquier caso, es necesario que se realicen trabajos científicos e imparciales, para analizar las implicancias de la modificación genética en el medio ambiente y la cadena alimentaria.

\section{Inocuidad alimentaria y preferencias de los consumidores}

Las percepciones del consumidor son dinámicas, y a menudo hay diferencias entre lo que perciben los consumidores y su comportamiento. Las últimas dos décadas han traído importantes cambios en el comportamiento de los consumidores. Entre las industrias de alimentos del mundo, la cadena cárnica es la que está enfrentando una mayor negatividad pública, especialmente debido a la asociación del consumo de carne con ciertos riesgos para la salud humana (enfermedades del corazón) y en segundo lugar por temores de inocuidad. Los principales riesgos relacionados con el consumo de carne percibida por los consumidores son los residuos químicos de las hormonas de crecimiento y antibióticos presentes en la carne, alto contenido de grasa y los riesgos conexos de colesterol creciente, las infecciones microbianas (por ejemplo: Salmonella, Escherichia coli, dioxinas), el uso de modificación genética en la producción de alimentos para animales, así como la Encelopatía Espongiforme Bovina (EEB).

Como un ejemplo de este riesgo y relacionados con la prevalencia de patógenos específicos en los alimentos, Desmarchelier et al. (2007) informaron que el grupo de pa- 
tógenos humanos más estudiado son la Escherichia coli enterohemorrágica. En una investigación de cortes de cordero australiano de presencia de la toxina shiga de Escherichia coli (STEC), Barlow et al. (2006) detectaron STEC en $40 \%$ de las muestras de cordero.

La mayor conciencia sobre la inocuidad alimentaria, así como los cambios en los patrones dietéticos y de consumo han despertado interés en estudiar las preferencias de consumo de carne fresca (Bernabeu y Tendero, 2005; Grunert, 2005). Diversos estudios se han centrado en conductas de consumo relacionados con la carne de cordero. Estudios anteriores han encontrado que atributos como la calidad y las percepciones de inocuidad alimentaria (McEachern y Willock, 2004; Rimal, 2005) han influenciado en las opciones del consumidor. En condiciones normales, los consumidores no son conscientes de la seguridad de los productos, pero los temores están presentes en un estado latente, y la percepción de inocuidad es crítica. Richardson et al. (1994) encontraron que la eliminación de microorganismos de la carne era una salvaguardia para la cual la mayoría de los consumidores paga un premio. Un segundo factor importante es el temor por los residuos, especialmente los antibióticos y las hormonas. En el $80 \%$ de los ciudadanos franceses entrevistados, la seguridad percibida (libre de microorganismos) se clasificó segunda sobre una base de cinco criterios de calidad de la carne, y casi el $24 \%$ de los ciudadanos británicos entrevistados declararon que la reducción en el consumo de carne fue debido al temor a los residuos (Richardson et al., 1994). En otro estudio, Corcoran et al. (2001), describiendo los factores que influyen en el consumo en un estudio de percepción del consumidor, mencionaron que los participantes estaban preocupados por cuestiones de seguridad en el consumo de carne. Por ejemplo, los británicos estaban más preocupados por la EEB y E. Coli y los franceses por contenido de hormonas y antibióticos.

En el informe especial Eurobarómetro 354 (2010), en la evaluación de la percepción pública de los alimentos y los riesgos relacionados con los alimentos, se mostró que la inocuidad alimentaria (37\%) fue menos asociada con los alimentos y calidad. También en este estudio, que agrupa los riesgos en tres categorías según las respuestas «muy preocupadas», se reporta que la segunda cuestión de mayor preocupación para los ciudadanos de la UE (70\%) es la presencia de residuos (como los antibióticos o las hormonas) en carnes.

Esta toma de conciencia de las cuestiones de seguridad relacionadas con los alimentos entre los consumidores de alimentos de hoy, está impulsando la demanda para obtener más información sobre la cadena alimentaria vertical y específicamente el origen y manejo de los alimentos generados y consumidos en todo el mundo (Smith et al., 2005). Los consumidores están comenzando la búsqueda de marcas y certificaciones que garantizan seguridad.

Para reducir la carga microbiana en la carne y la transmisión de enfermedades y residuos químicos es importante desarrollar sistemas de gestión de seguridad alimentaria basados en análisis de riesgo. EI HACCP proporciona la base para el sistema de gestión de seguridad alimentaria. Los siete pasos esenciales para el HACCP son indicados por la Comisión del Codex Alimentarius (Codex, 1991) y abarca todas las fases de la cadena alimentaria (desde la producción hasta la venta al por menor) (Troy y Kerry, 2010). Los procesadores de carne están obligados a poner en práctica sistemas de gestión de procesos aprobado por el HACCP y para la exportación también deben cumplir con los requisitos del país importador. Sin embargo, el enfoque global de la cadena de carne debería incorporar la identificación y trazabilidad siendo significativo para los consumidores en términos de sus beneficios como la inocuidad y calidad. En el área de la carne, hay una necesidad de disponer de sistemas rápidos y confiables para permitir la trazabilidad a lo largo de la cadena de suministro para proporcionar alimentos seguros y de alta calidad para el consumidor.

La trazabilidad se define como la capacidad de mantener un seguimiento creíble de identificación para los animales a través de varios pasos dentro de la cadena alimentaria, 
desde la unidad productiva hasta el comercio. La trazabilidad de un producto alimenticio consiste en desarrollar un rastreo de información (Smith et al., 2005). Garantiza la retirada de alimentos si se exige. En el sector cárnico, la trazabilidad ofrece la capacidad de identificar un animal, rastrear su movimiento a lo largo de su vida y trazar los productos de carne generados por ese animal hasta el consumidor final (Verbeke, 2003). Las agencias reguladoras establecieron la implementación y aplicación de sistemas de trazabilidad de productos cárnicos desde la producción hasta los consumidores. El Uruguay es un buen ejemplo de la implementación y aplicación de uno de estos sistemas (Instituto Interamericano de Cooperación para la Agricultura -IICA, 2009).

Coff et al. (2008) definieron los objetivos de la trazabilidad en los alimentos para: a) el manejo del riesgo e inocuidad alimentaria, b) el control y verificación, c) la cadena de suministro y la eficiencia, d) la certificación de calidad de los productos y e) la información y comunicación para el consumidor.

Du Plessis y Du Rand (2012) reportaron que el precio es conocido como el factor más determinante en la decisión de compra del consumidor. Un precio más alto a veces puede simbolizar una mejor calidad y la inocuidad del producto para los consumidores. La seguridad es el atributo más importante después de precio y se encontró que el $23,1 \%$ efectivamente tienen en cuenta este factor en la decisión de compra. Estos autores utilizando valores de utilidad para la seguridad demostraron que los consumidores preferían seguridad de carne de cordero a través de la certificación, seguido por la innocuidad a través del lugar de compra y luego a través de etiquetas y marcas.

Los requisitos de acceso a mercados continúan siendo un desafío para los países de exportación de carne. Galyean et al. (2011) observaron que el énfasis en la eficiencia económica en los sistemas de producción de carne, asociados con los esfuerzos para reducir las emisiones y mantener los más altos estándares de bienestar animal e inocuidad de alimentos, garantizará el futuro, a largo plazo, de la cadena cárnica norteamericana. Además, la preocupación del público por la inocuidad, ha inducido hacia una mayor preocupación por la trazabilidad animal (Galyean et al., 2011). Inocuidad, trazabilidad y calidad del producto son también los principales impulsores de la cadena cárnica en Brasil (Millen et al., 2011). En Argentina, la inocuidad y trazabilidad se consideran motores importantes para sostener la producción animal (Arelovich et al., 2011). Para otros países como Australia, Nueva Zelanda y Uruguay, las prioridades de investigación en carne se centran en la seguridad e inocuidad, y donde los sistemas de producción tienen que ser éticos desde el punto de vista del bienestar animal y ambiental; todos ellos son esenciales para mantener una posición competitiva en el mercado (Desmarchelier et al., 2007; Montossi y Brito, 2012).

\section{Efecto de los sistemas de producción sobre la aceptabilidad de la carne de cordero por el consumidor}

Los sistemas de producción ovina son muy variables entre y dentro de los países porque se relacionan con diferentes condiciones ambientales y prácticas agrícolas (Sañudo et al., 2007). Las preferencias de carne cordero por los consumidores son afectadas por los sistemas de producción, dado que estos están vinculados con las características sensoriales de la carne de cordero y además asociados a aspectos culturales 0 los hábitos de consumo, a las actitudes del consumidor, creencias, sentimientos y consideraciones morales. Uno de los factores más importantes relacionados con los sistemas de producción animal es la alimentación animal. Sepúlveda et al. (2011) encontraron que ambos, consumidores y productores, consideran la alimentación animal como el aspecto más importante de producción relacionado con la calidad de carne cordero.

El tipo de alimentación afecta la composición de la cordero carne y, en consecuencia sus características sensoriales (ver comentarios de Duckett y Kuber, 2001; Melton, 
1990; Priolo et al., 2001; Schreurs et al., 2008). Se han reportado diferencias entre diferentes regímenes de alimentación con pasto (ÅdnØy Haug et al., 2006; Dervishi et al., 2011; Fraser et al., 2004; Lourenço et al., 2007; Park et al., 1972) así como de diferentes regímenes de alimentación en base a concentrados (Ponnampalam et al., 2002; Ray et al., 1975), o por otras características intrínsecas o extrínsecas. Además, se encuentran diferencias importantes en el sabor, olor y textura de la carne en corderos alimentados a pasto en comparación con los alimentados con concentrado, lo que a su vez afecta la aceptabilidad del consumidor por carne de cordero.

En general, se ha reportado que la carne de cordero alimentado con pasto tiene un mayor contenido de sabores desagradables (Resconi et al., 2009; Young et al., 2002), mayor olor y sabor intenso de «borrego» (Sañudo et al., 1998; Madera y Fisher, 1990) y más sabor rancio, ácido o a hígado (Priolo et al, 2002; Resconi et al., 2009) que la de corderos alimentados con concentrado. Por otro lado, se ha divulgado que la carne de corderos alimentados con concentrado tiene mayor terneza y un aroma más favorable y sabor de cordero (Priolo et al., 2002; Resconi et al., 2009; San Julián et al., 2007). Estas diferencias sensoriales son debidas a diferentes componentes de la carne de cordero presentes en la carne fresca o son generados durante la cocción. La cantidad y calidad de grasa de cordero tiene un papel importante en las características organolépticas de la carne. En este sentido, corderos alimentados con concentrados tienen un mayor contenido de grasa intramuscular (Díaz et al., 2002; Priolo et al., 2002, San Julián et al., 2007; Schönfeldt et al., 1993; Smith et al., 1976) que la carne de los corderos alimentados con pasturas. El perfil de ácidos grasos también es diferente dependiendo de los sistemas de producción. En general, los corderos alimentados con pasto tienen mayor contenido de ácido linoleico conjugado (ALC) y ácido $\alpha$-linolénico (Aurousseau et al., 2004; Cañeque et al., 2007; Enser et al., 1998; Kemp et al., 1981). La oxidación de $\alpha$-linolénico ha sido relacionada con el sabor pastoril (Young y Baumeister,
1999). Además, la carne de corderos alimentados con pasturas tiene un menor PUFA total (Kemp et al., 1981), más ácidos grasos Poliinsaturados n-3 y una menor relación de ácidos grasos poli-insaturados n-6/n-3 (Enser et al., 1998; Resconi et al., 2009), que ha demostrado ser favorable para la salud humana (McAffee et al., 2011). Estas diferencias en la composición de la grasa de cordero debido a los diferentes regímenes de alimentación, afectan la aceptabilidad sensorial de los consumidores (Dransfield et al., 2000; Font i Furnols et al., 2006, 2009; Joy et al., 2012; Sañudo et al., 2007).

Por otra parte, la cultura o los hábitos de consumo también juegan un papel importante en esta aceptabilidad (Alfonso et al., 2000; Font i Furnols et al., 2006, 2009; Sañudo et al., 1998, 2007; Fisher et al., 2000), explicando diferentes actitudes del consumidor hacia la carne de cordero, que pueden afectar sus decisiones de compra (Sañudo et al., 2007; Verbeke y Vackier, 2004). Esto puede verse claramente en los resultados de un estudio realizado a gran escala en la Unión Europea (FAIR3-CT-1768 - proyecto OVAX) para evaluar el efecto del tipo de cordero sobre las diferentes aceptabilidades del consumidor a través de evaluaciones realizadas en sus propios hogares. Además de las diferencias encontradas en las puntuaciones de los consumidores entre países, probablemente influenciados por su grado de consumo de cordero o consideración sobre la carne de cordero, la mayoría de la variabilidad total $(86,2 \%)$ en las puntuaciones de cordero fue explicada por el sistema de producción involucrado en cada tipo de cordero producido. En este sentido, los corderos criados con concentrado o leche, con un sabor menos intenso, eran claramente asociados con los países mediterráneos, mientras que los corderos alimentados con pasturas, con un sabor más intenso, se asociaron con los países del norte de la UE (Alfonso et al., 2000; Sañudo et al., 2007). Esto puede explicar por qué algunos consumidores no están acostumbrados al sabor de la carne ovina que presentan los corderos alimentados a pasto y prefieren carne de cordero alimentados con concentrado y viceversa (Font i Furnols et al., 2006). Este proyecto también 
demostró que corderos de un año de edad (manejados bajo el sistema de trashumancia) fueron claramente detectados por los consumidores, ya que es un tipo local de cordero que la mayoría de los consumidores no estaban acostumbrados a consumir. Los resultados sugieren un vínculo entre las evaluaciones de un tipo determinado de cordero y los antecedentes culinarios de los consumidores, las experiencias pasadas y hábito sensorial, demostrado previamente por los paneles sensoriales (Fisher et al., 2000; Sañudo et al., 1998). También dentro de un país, cuando se compararon diferentes productos nacionales dentro de una región específica, los más conocidos localmente demostraron tener las más altas puntuaciones de aceptabilidad (Martínez-Cerezo et al., 2005). Para los consumidores, el uso de sistemas criados intensivamente con la inclusión de concentrados en las dietas, incluso bajo condiciones de pastoreo, parece ser la mejor opción para asegurar la aceptabilidad (Font i Furnols et al., 2009).

Con respecto a las creencias de los consumidores, las preferencias son mayores para el cordero proveniente de los sistemas de producción basados en pasturas en comparación con el cordero alimentado con concentrados (Font i Furnols et al., 2011). Esto probablemente se asocia con las creencias y expectativas por parte del consumidor, quien en última instancia, relaciona que los sistemas de producción pastoril producen una carne más saludable, más natural y más sabrosa y son también más amigables con el medio ambiente en comparación con los sistemas más intensivos de alimentación (Font i Furnols et al., 2011). Estas preferencias fueron demostradas hacia la carne vacuna producida en base a pasturas (Verbeke et al., 2010) y para los sistemas de producción orgánica de cerdo (Grunert et al., 2004). Por otra parte, los consumidores preferían carne de cordero de pasturas de la montaña que aquellos de los pastizales de tierras bajas (Hersleth et al. 2012; Imami et al., 2011). La carne de cordero proveniente de pasturas de la montaña se asoció a sistemas de producción que producen carne de cordero de mejor sabor, más natural, más sana y con mayor cuidado del ambiente y bienestar animal, así como a la especificidad genética de plantas y animales que pueden producir una especificidad sensorial muy prometedora (Hersleth et al., 2012). Adicionalmente, también se ha demostrado que las expectativas de los consumidores hacia carnes de cordero originadas en diferentes sistemas de producción necesariamente no se confirman cuando los consumidores prueban (experimentan) la carne en condiciones sin saber su origen (Font i Furnols et al., 2011).

Es así, que las creencias de los consumidores son muy importantes y afectan la intención de compra de los mismos. Más aún, estas creencias con respecto a la carne de cordero son diferentes según el segmento de consumidores considerado, lo cual determina dichas creencias o intenciones de compra (Font i Furnols et al., 2011; Sepúlveda et al., 2011).

El etiquetado sobre la información sobre sistemas de producción donde se genera la carne (principalmente alimentación animal y las prácticas de producción amigable con el medio ambiente) son relevantes para un importante segmento de consumidores que están muy preocupados por la inocuidad de la carne de cordero, nutrición, salud y satisfacción sensorial obtenidas (Bernués et al., 2003a,b). No obstante, los consumidores no suelen tener información acerca de estas señales extrínsecas y, en consecuencia, no pueden usar esta información en su evaluación de la calidad (Bernués et al., 2003b) para confirmar o descartar sus expectativas. Sin embargo, algunos trabajos han demostrado que el hecho de proporcionar información a los consumidores sobre la alimentación o las prácticas de bienestar animal en términos de condiciones de crianza previo al consumo de cordero, influenció la aceptabilidad por parte del consumidor, moviéndola hacia la satisfacción de sus expectativas (definido como «efecto de asimilación») (D'Alessandro et al., 2012; Napolitano et al., 2007a; Piasentier et al., 2007). Este efecto es muy importante porque demuestra la influencia de la información sobre la aceptabilidad de carne de 
cordero por los consumidores, así como la importancia que los consumidores otorgan a la carne producida de forma sustentable y «naturalmente» en regímenes de alimentación en base a pasturas, lo que podría ser utilizado en las estrategias de marketing.

\section{Las percepciones del consumidor y el bienestar animal}

Los consumidores cada vez más critican la globalización de la producción agrícola y cuestionan las consecuencias económicas, ambientales y sociales del comercio mundial (Raynolds, 2000; Abbott, 2003; Jones et al., 2003). El consumismo ético está ganando importancia en las decisiones de compra de alimentos (Shaw y Shiu, 2001; Vermeir y Verbeke, 2006; Newholm y Shaw, 2007; Miele y Evans, 2010) y buenos ejemplos de esta tendencia en el mercado de alimentos son «Fairtrade» (en español: «comercio justo») y los productos orgánicos (en parte), son los que han exhibido tasas de crecimiento muy importantes en los últimos años (Zander et al., 2013).

Durante los últimos 20 años, la literatura ha estado indicando que los consumidores están adquiriendo un creciente interés por las prácticas agrícolas y relacionadas con los estándares de bienestar animal para definir las compras de alimentos de origen animal (Verbeke y Viane, 1999; McInerney, 2004). En 2001, Harper y Henson (2001) determinaron que los consumidores en los países occidentales están más influenciados por los aspectos éticos de la producción de alimentos que por su costo, y existe un creciente interés en los estándares de bienestar animal asociado con las prácticas de producción. En 2003, Blokhuis et al., informaron que el bienestar de los animales es reconocido como un componente importante de la certificación de calidad de productos de origen animal para los consumidores. Sin embargo, los resultados de varias investigaciones han sido concluyentes con respecto a la importancia del bienestar animal al elegir carne. Según el Eurobarómetro Especial (2005), casi la mitad de todos los ciudadanos de la UE cree que el bienestar de los animales y su protección dentro de la UE son mejores que en otras partes del mundo, pero una ligera mayoría de ciudadanos de la UE (52\%) parecen no tener en cuenta la cuestión del bienestar animal cuando compran alimentos. En Escocia, Schröder y McEachern (2004) también concluyeron que los consumidores evitan comprar productos cárnicos producidos en sistemas intensivos si el manejo de animales afecta la calidad de la carne, pero encontraron una baja proporción de consumidores dispuestos a pagar más por dichas carnes. McCarthy et al. (2003) informaron que el bienestar animal no afectó significativamente la actitud hacia la carne y su consumo en Irlanda. Algunos estudios destacan que el bienestar de los animales es relativamente menos importante que otros atributos, tales como la alimentación, el origen de los animales (Bernués et al., 2003a), el precio y la apariencia del alimentos (Davidson et al., 2003). Napolitano et al. (2007b) concluyeron que si la carne es aceptable en términos de sus propiedades sensoriales, la información sobre el bienestar de los animales y características nutricionales permite a los consumidores obtener una percepción más positiva del producto y aumentar la aceptabilidad de la carne en Italia. Estudios recientes de la Unión Europea indicaron que los consumidores están dispuestos a 'consumir alimentos provenientes de «sistemas de producción amigables» porque los asocian con una más alta calidad y sanidad (Eurobarómetro especial, 2007; Napolitano et al., 2007b).

Del mismo modo, se ha reportado que la sensibilidad con respecto al bienestar de los animales difiere según el género, el nivel de educación, ocupación (María, 2006), edad (Bernués et al., 2003a; María, 2006), país de residencia (Bernués et al., 2003a; María, 2006) y lugar de residencia de los consumidores (Bernués et al., 2003a). Grunert y VaIli (2001) identificaron un segmento de consumidores muy particular, caracterizado por ser gente joven con altos ingresos y niveles educativos, para quienes es muy importante que los animales reciban un tratamiento animal apropiado. En España, Sepúlveda et al. (2011) también informaron que aún cuando la producción sea ecológica y las prácticas 
de producción respeten el bienestar de los animales, éstos están entre los aspectos que son menos valorados en el momento de la compra y existe un segmento de consumidores jóvenes, para quienes estos aspectos merecen una calificación más alta. También hay evidencia que sugieren que las personas que ya han visitado un establecimiento que cría de animales son más propensos a tener en cuenta el bienestar de los animales que serán fuente de productos cárnicos (Eurobarómetro Especial, 2005). Por lo tanto, estudiando los hábitos de consumo y actitudes hacia ciertos atributos de la carne se debe tomar en cuenta la segmentación del consumidor. En ese sentido, también debería ser muy importante a tener en cuenta las diferencias significativas dentro del país o entre países, para desarrollar estrategias de marketing (demanda orientada) en Europa (Font i Furnols et al., 2011) y en el mundo, por parte de los productores y exportadores de carne de cordero.

El tema del bienestar de los animales también está ganando importancia en las Américas (Schnettler et al., 2009). Los tradicionales países exportadores de carne (Argentina, Brasil, Canadá, Estados Unidos, Paraguay y Uruguay) y los emergentes (Chile y México) han incorporado diferentes aspectos del bienestar de los animales en sus reglamentos y prácticas, asociadas principalmente a las exportaciones de carne vacuna (Rojas et al., 2004). Sin embargo, la actitud de los consumidores latinoamericanos hacia el bienestar de los animales todavía no es bien conocido (Schnettler et al., 2009).

Señales de información sobre los factores del medio ambiente, bienestar animal y alimentación de los animales son relevantes para muchos consumidores (Bernués et al., 2003b). Por otra parte, estudios previos acerca de los productos orgánicos, muestran que este tipo de información puede aumentar notablemente la voluntad del consumidor de pagar (Napolitano et al., 2010). A pesar de este creciente interés en la información, los valores éticos raramente se comunican a los consumidores (Zander y Hamm, 2010).

Ha sido destacado, que la investigación informó que los consumidores tienen una imagen favorable sobre los sistemas de ga- nadería extensiva y los asocian con atributos positivos acerca de la carne de cordero, mientras que los sistemas más intensivos crean expectativas negativas y pueden influir y penalizar la evaluación cualitativa de la carne. Incluso cambian previos puntajes de satisfacción, de ternura, sabor o jugosidad de pruebas a «ciegas» anteriores mostrando un efecto de asimilación (D'Alessandro et al., 2012). Por lo tanto, la información sobre el bienestar animal, expresado en términos de condiciones de crianza, puede ser un determinante mayor de la aceptabilidad de alimentos de origen animal, proporcionando así una herramienta potencial para la diferenciación de carne en los establecimientos tradicionales donde la cría se basa en sistemas extensivos de cría y altos estándares de bienestar animal.

Independientemente de la especie animal, la carne fresca generalmente se comercializa como un producto indiferenciado (Napolitano et al., 2007b) especialmente el cordero (Grunert y Valli, 2001; Grunert, 2006). Los productores ovinos y la cadena cárnica ovina deben tener en cuenta que el sistema de alimentación es considerado por algunos consumidores como un atributo clave de calidad extrínseca de la carne (Bernués et al., 2003a; Sepúlveda et al., 2011) y que los consumidores prefieren sistemas de alimentación de pasturas y forrajes en lugar de los sistemas a base de cereales (Font i Furnols et al., 2011). Esto sumado a las ventajas para la salud humana del consumo de carne de cordero alimentados con pasto (Cañeque et al., 2008) implica que los países exportadores con sistemas de producción pastoril predominante, como son los casos de Australia, Nueva Zelanda y Uruguay, tiene un importante efecto divulgar información sobre el bienestar de los animales asociado con las condiciones y la aceptabilidad del producto, lo que podría dar algunas indicaciones sobre la posible manera de distinguir productos de carne de ovina con mayor aceptabilidad (McInerney, 2004). Dicha información, divulgada a los consumidores debería basarse en información científica sólido que cubra los aspectos de los sistemas de producción (del Campo, 2008; 2011; del Campo y Montossi, 2007) donde se aborden las 
preocupaciones éticas del consumidor sobre el bienestar animal (Napolitano et al., 2007b). El doble desafío debería ser la generación de información objetiva sobre las ventajas comparativas de los sistemas extensivos con relación al bienestar animal, pero no menos importante, para mejorar las prácticas de manejo asociadas en estos sistemas que pudieran comprometer el bienestar de los animales (del Campo, 2012), incluso en el caso de que las amenazas no sean directamente percibidas por los consumidores.

\section{Efecto de origen sobre la aceptabilidad de carne de cordero}

Los sistemas de producción ovina varían considerablemente en todo el mundo y reflejan las diferentes condiciones ambientales locales, que determinan, en gran parte, factores tales como: razas, instalaciones, nivel de intensificación, prácticas de manejo, cuestiones ambientales y sistemas de alimentación de los animales. Los componentes de los sistemas de producción se consideran los más importantes para determinar la calidad en la producción animal (Sepúlveda et al., 2011). Por esta razón, la carne de cordero tiene características sensoriales diferentes dependiendo de su origen, al ser un producto fuertemente dependiente de país. Por lo tanto, la evaluación sensorial de carne de cordero por los consumidores de diferentes orígenes puede producir diferencias en su aceptabilidad. Sin embargo, aparte de estas diferencias sensoriales, existen otros aspectos inherentes a los consumidores que afectan sus evaluaciones y preferencias por la carne dependiendo de su origen. Al final de la cadena de suministro, los requerimientos del mercado y cualidades también desempeñan una influencia relevante en la calidad que se necesita.

El origen es una importante señal extrínseca que afecta las preferencias de los consumidores en las decisiones de compra de alimentos, siendo, en general, los productos locales o nacionales los más preferidos por los consumidores, dado que son considerados los más frescos, sabrosos y de mayor calidad (Chambers et al., 2007). El efecto del origen incluye aspectos relacionados con el consumo, las creencias, sentimientos o emociones y consideraciones morales (Obermiller y Spangenberg, 1989) así como la interacción entre ellos (Verlegh y Steenkamp, 1999). Además, en este sentido, las expectativas creadas por los consumidores debido al origen de cordero pueden influir en su preferencia o aceptabilidad, ya sea positiva o negativamente (Pauselli et al., 2009). Sin embargo, esta preferencia de origen depende de varios factores como el tipo de producto, las características del país de origen en términos de desarrollo económico, las características de producción, y similitudes en cultura y también, las características socio-demográficas de los consumidores (Alfnes, 2004; Cowan, 1998; Juric y Worsley, 1998; Kaynak et al., 2000; Schnettler et al., 2008). El etnocentrismo del consumidor es un aspecto normativo relacionado con el país de origen y sucede cuando los consumidores creen que la adquisición de productos importados es negativa para la economía doméstica, por moralidad y patriotismo (Shimp y Sharma, 1987) y, en consecuencia, los consumidores sobreestiman los productos locales, los prefieren y están moralmente obligados a su compra (Sharma et al., 1995).

Históricamente, se ha demostrado que en las zonas con bajo consumo de carne ovina (por ejemplo Asia Central y del Sureste y Estados Unidos), ello se debe generalmente a su fuerte sabor y olor. Sin embargo, en áreas donde se consume frecuente y abundantemente carne ovina (por ejemplo, Medio Oriente y Nueva Zelanda), los consumidores aparentan disfrutar de su sabor distintivo (Jamora y Rhee, 1998; Rubino et al., 1999). Además, diferentes estudios demuestran que la carne de cordero es la más preferida a nivel local, regional o nacional (Bernués et al., $2003 \mathrm{ab}$; Hersleth et al., 2012; Pauselli et al., 2009), incluso para los segmentos de consumidores que dan una menor importancia al origen de la carne (Font i Furnols et al., 2011) o independientemente de la frecuencia de consumo de carne de cordero (Bernabeu y Tendero, 2005).

Además, estudios realizados con panelistas entrenados y otros con consumi- 
dores de carne de cordero (Griffin et al., 1992; Sañudo et al., 1998), investigaron la dependencia entre los antecedentes culinarios y la aceptabilidad de la carne, y encontraron algunas claras relaciones entre el conocimiento del producto y su aceptación. Además, Font i Furnols et al. (2006) encontraron que los consumidores europeos aprecian más la carne de cordero autóctono que la carne de ovinos que habían sido criados en sistemas de producción pastoril de América del Sur. Por otro lado, los canadienses (Jeremías, 1988) no detectaron grandes diferencias en el sabor y la textura de la carne de corderos de diferentes orígenes como Australia, Nueva Zelanda y Canadá, probablemente debido a que dichos ovinos venían de similares sistemas de cría y pesos de canal. Esta tendencia también se demuestra incluso cuando la carne no ha sido probada, así, en un estudio sobre la aceptabilidad de la carne ovina, comparando 4 países europeos (España, Reino Unido, Alemania y Francia) con diferentes etiquetas, demostraron que el cordero con la etiqueta suiza era el segundo preferido luego de la carne de cordero local, siendo menos preferida la carne de cordero de Argentina o Uruguay. Los autores suponen que esta preferencia diferencial fue debido al hecho de que Suiza tiene un nivel de desarrollo y de sistemas sociales similar al resto de los países europeos involucrados en el estudio y también dada por la cercanía de esos países, donde la carne puede ser percibida como más fresca y saludable (Font i Furnols et al., 2011). Este resultado indica la importancia de las características del país de origen de la carne de cordero en las preferencias de los consumidores. En otro trabajo realizado en Inglaterra, Francia, Italia, Escocia y España, el origen de la carne también era importante en todos los países. Cuando se establecieron los segmentos de consumidores, más preocupados por el origen de la carne fueron principalmente los consumidores de las ciudades de tamaño mediano y grandes (Bernués et al., 2003b), indicando la influencia de las características socio-demográficas de los consumidores en sus preferencias.
En otros estudios de investigación, el origen de la carne ha sido asociado con carne inocua y saludable, especialmente en la carne vacuna pero también pasó en pollo y cerdo (Cowan, 1998). Esta relación, también ha sido señalada para corderos por los consumidores italianos (Hersleth et al., 2012), aunque no fue confirmado en un estudio español (Bernués et al., 2003a).

Información sobre señales extrínsecas como el origen y los sistemas de producción no está generalmente disponible para los consumidores. Una de las maneras de proporcionar esta información es el uso de una marca o un Esquema de Denominación de Origen, teniendo en cuenta que la marca es una herramienta para colaborar con los consumidores para asociar el producto con diferentes atributos del proceso de producción (Acebrün y Dopico, 2000; Bernués et al., 2003a). Las etiquetas en carne de cordero, incluyendo las orgánicas (Angood et al., 2008), pueden crear expectativas positivas para el consumidor. También es importante que los consumidores lo confirmen mediante una experiencia sensorial favorable durante la evaluación de la carne, para evitar una futura disconformidad y riesgo de fracaso (Piasentier et al., 2007). En este sentido, la trazabilidad y certificación son importantes (Du Plessis y Du Rand, 2012), las cuales son herramientas fundamentales para asegurar este proceso. En Europa, existen diferentes indicaciones geográficas y especialidades tradicionales para garantizar el origen de algunos productos en términos de su producción, procesamiento o preparación. Este es un enfoque a profundizar en el futuro.

\section{IMPLICANCIAS}

Las cadenas cárnicas ovinas del mundo son muy diferentes entre sí, debido a las enormes variaciones existentes entre países en términos de los recursos naturales disponibles, características socioeconómicas, problemas geopolíticos, diferencias tecnológicas y culturales, entre otras. Por lo tanto, los autores del presente artículo son muy conscientes que muchas de las propuestas 
tecnológicas realizadas así como el enfoque establecido en este artículo, tienen sus ventajas y desventajas tecnológicas y productivas dependiendo de cada caso que se considere, y están condicionadas por una serie de otras limitantes y oportunidades como los accesos a los mercados, las políticas de Estado, restricciones sanitarias, grado de coordinaciones entre los diferentes actores de la cadena, entre otras. También es importante destacar la influencia decisiva que tiene la cultura, creencias, valores y elementos que hacen a la educación integral de los integrantes de la cadena cárnica ovina y de los consumidores (internos y externos) que definitivamente generan las oportunidades que tiene cada país en generar cambios cuantitativos y cualitativos en beneficio de la competitividad de su cadena de carne ovina.

Este trabajo se ha centrado en las evaluaciones de las interrelaciones que existen entre los factores asociados a la producción y las preferencias del consumidor. Reconocemos la existencia de otros factores y sus efectos relevantes en la competitividad de la cadena cárnica ovina como lo son: el transporte de animales, procesamiento y empaquetado, cocción, comercialización de la carne y posición de los medios de comunicación, lo cual tendrá una respuesta influyente particularmente en la preferencia de los consumidores, pero están fuera del alcance de este artículo.

Basado en la información presentada en este artículo, los autores concluyen que indudablemente «nosotros» (las cadenas cárnicas ovinas y las sociedades del mundo) no tienen una sola respuesta para establecer estrategias y soluciones globales para resolver muchas de las contradicciones y los conflictos generados entre la intensificación de los sistemas de producciones, las cuestiones de la sostenibilidad (con sus tres dimensiones, económicas, sociales y ambientales), las preferencias del consumidor, y sus creencias y valores. Además, los sistemas de producción extensivos también tienen sus propias limitaciones reales y potenciales para generar una respuesta y acción proactiva y efectiva frente a algunas de las dificultades impuestas por los cambios que se observan en las tendencias de opinión de los consumidores, a nivel global y particular.

En muchos casos, la intensificación y la automatización de los sistemas de producción ovina parecen ser una respuesta positiva para aumentar la productividad y rentabilidad e incluso promover la generación de impactos positivos a nivel ambiental (ej.: la reducción de las emisiones de gases efecto invernadero). Sin embargo, no todos los productores se beneficiarán de este enfoque de la misma manera, dada la necesidad adicional de capital e inversión, nivel educativo, edad, apoyo institucional necesario, y la motivación personal y familiar necesaria para seguir adelante con este enfoque establecido, particularmente en aquellos productores de pequeña escala. El número de productores ovejeros es muy importante a nivel mundial, por lo tanto, las regulaciones de los gobiernos y los acuerdos entre gobiernos o bloques de países, deben tomarlos en cuenta desde el punto de vista económico, social y ambiental, para mantener a ellos y sus familias en el sector rural, particularmente en áreas extensivas, marginales y remotas.

Existe una clara evidencia científica generada por los estudios de percepción del consumidor, especialmente los realizados en mercados importantes (por ejemplo: EU) dominados por un consumidor con estilo de vida occidental, y de ingresos medio a alto, que ha demostrado una opinión negativa acerca de la intensificación productiva, porque estas prácticas se alejan de las formas «naturales» de producción. Además, la carne de cordero producido a pasto es más saludable para los seres humanos que la producida en sistemas basados mayoritariamente en la alimentación con concentrados. El hecho de promover el consumo de carne ovina producida a pasto, debe entenderse e interpretarse de una forma más holística, buscando potencializar sus ventajas sinérgicas, ya que: a) contribuye a una dieta más equilibrada y saludable y $b$ ) es percibida por el consumidor como carne producida bajo una forma más amigable con el medio ambiente. Esta es una oportunidad clave para usar estos atributos de los sistemas de producción pastoriles para desarrollar estrategias de marketing que 
favorezcan el consumo de carne de cordero frente a otras carnes alternativas.

Las percepciones, creencias, y los valores de los consumidores son muy importantes en la determinación de la aceptabilidad de la carne. La mayoría de los consumidores prefieren carne producida en un contexto más «sostenible». Sin embargo, después de consumir la carne, las preferencias originales de los consumidores por estas pueden cambiar sustancialmente (por ejemplo preferir carne producida en base a granos), a menos que se proporcione información complementaria sobre el origen y el sistema de producción utilizado para generar esa carne. Ello establece claramente la importancia de comprender las expectativas de los consumidores, que son influenciados por emociones, sentimientos y creencias, y fortalecen la estrategia de tener estos elementos en consideración en campañas de marketing. Dentro de algunos segmentos de consumidores en mercados de alto poder adquisitivo, el precio de la carne también afecta a las decisiones de compra.

No hay ninguna duda sobre la importancia actual y futura que tiene el mejoramiento genético en la mejora de la competitividad de la cadena cárnica ovina. Existen muy buenos ejemplos del progreso genético obtenido (favorable) para diferentes características de alta importancia económica en la producción de carne ovina, sobre todo en el crecimiento y calidad de canal, y en menor magnitud sobre la calidad de la carne. En el mundo, el uso de la selección genómica, es de más reciente aplicación a nivel de la cadena cárnica ovina en comparación con otras industrias animales y ello se trasforma en una limitante importante de cara al futuro. Son pocos los productos generados por la selección genómica que estén disponibles a nivel comercial para los productores, y menos para características cualitativas de la canal y carne. Sin embargo, el potencial futuro de esta tecnología es enorme y abre una nueva era para el mejoramiento genético animal y su mayor impacto relativo en las cadenas de valor. Además, el siguiente paso a dar en la ciencia y el propio agronegocio, es la aplicación de la ingeniería genética en la selección animal, que podrían revolucionar la producción animal mundial, especialmente cuando el agua y los recursos de la tierra sean aún más escasos y donde la producción de carne tiene y tendrá que competir aún más con otras alternativas muy rentables como es el caso de la agricultura. Sin embargo, en un futuro próximo, la probabilidad de tener productos comerciales GM en el mercado es baja para los productores ovinos, y también se enfrentará con una clara percepción negativa de parte del consumidor.

Los consumidores, principalmente en los países industrializados (liderados por la UE) están prestando más atención a la calidad de vida del animal en los sistemas de producción. Esta tendencia va acompañada por reclamos éticos y presión de grupos de bienestar animal así como por un incremento en la reglamentación oficial o privada, que exigen la implementación de mejores prácticas de manejo para promover el bienestar de los animales en los sistemas productivos. Un sistema de producción sostenible, holísticamente, incluye el componente de bienestar animal, donde los productores son responsables por el bienestar de los animales frente a la sociedad. Esto es sin duda, también, un tema de comercio internacional, que también está ganando seguidores a nivel de muchos países del mundo.

Con un enfoque sistémico, este artículo ha abordado varias ventajas y desventajas de los sistemas de producción ovina extensiva e intensiva, donde existen oportunidades de mejora en el mercado de carnes. También se destaca que las propuestas de la instrumentación de prácticas de bienestar animal para los sistemas de producciones intensivas no se pueden aplicar directamente en los sistemas de producción extensiva. Los manuales de buenas prácticas animales tienen que contemplar las importantes diferencias que existen entre los sistemas de producción con diferente grado de intensificación. El avance de la ciencia, la educación y la formación de individuos a lo largo de la cadena cárnica ovina son claves para mejorar el bienestar de los animales. Este proceso tiene que ir acompañado de una comunicación adecuada y eficaz al resto de la sociedad. Por último, la mejora del bienestar animal en el mundo es parte de una 
nueva realidad, y debe ser comprendido con un enfoque holístico (ético, cultural, medio ambiental, social y económico) y se sustenta sobre el apoyo y el progreso de la ciencia, respetando la diversidad y realidad entre los países desarrollados y subdesarrollados, basado todo ello en la cooperación mutua entre los diferentes actores de la cadena cárnica ovina y la sociedad.

El consumo de carne se asocia con ciertos riesgos y mitos sobre la salud humana y seguridad alimentaria. Para reducir este potencial riesgo, entre otros, deberían desarrollarse sistemas de información que incluyan especialmente el origen y el manejo de productos cárnicos, con el fin de garantizar la higiene del producto y la salud humana. La aplicación del HACCP proporciona la base fundamental para la gestión de la inocuidad alimentaria, que debe ser acompañado por la información que genera la trazabilidad a lo largo de la cadena cárnica. En algunos casos, la innocuidad del producto es un factor determinante de las decisiones de compra del consumidor.

Se debe destacar las oportunidades de mercado que ofrece la carne Halal, la cual representa un gran potencial de la producción de cordero y por lo tanto, y merecería prestar más atención a la producción de cordero de una manera más sostenible que puede utilizarse también para este tipo de mercado.

A nivel mundial, las inversiones públicas y privadas en investigación e innovación en producción de carne de cerdo, de pollo y vacuna son sustancialmente más altas que en la carne ovina, y no vemos ningún cambio sustancial en esta realidad para el futuro cercano. Esto refleja el tamaño y el tipo de negocio entre las diferentes carnes a nivel mundial. En el largo plazo, esta realidad probablemente afecte negativamente el progreso genético, la productividad y la eficiencia de los productores de carne ovina en comparación con las otras carnes alternativas. Habida cuenta de la posibilidad que este posible escenario se alcance, la manera de mantener o incluso aumentar la participación de carne ovina en el consumo total de carne dependerá probablemente de las posibilida- des y logros que se obtengan en su diferenciación y valor agregado, ofreciendo un producto seguro, único, sano, sabroso y diferenciado, particularmente para ofrecer a aquellos consumidores que desean y son capaces de pagar por esta carne diferenciada.

También está demostrado que se puede realizar una producción sostenible con diferentes niveles de intensificación, con un mayor o menor efecto sobre la calidad de la carne ovina, los costos de producción, bienestar animal o medio ambiente, entre otros. Por lo tanto, es importante encontrar un equilibrio entre la sostenibilidad a nivel productivo, la calidad de la carne producida y contemplar las preferencias de los consumidores.

Apoyamos la estrategia de vincular y conectar los sistemas de producción con las preferencias de los consumidores, eso conlleva que las prácticas y tecnologías que se aplican en estos sistemas contemplen las preferencias de diferentes segmentos de consumidores y de esa manera ganar su confianza y lealtad en los diferentes nichos del mercado que ofrece la carne de ovina. Este enfoque tiene que ir acompañado por las verificaciones y certificaciones pertinentes a nivel productivo y de procesamiento, y un aseguramiento de la calidad e inocuidad del producto, incluyendo el etiquetado. Entre otros, las etiquetas y/o marcas deben incluir la identificación del país de origen y el valor nutritivo de la carne. Esto no es nuevo en el mercado de la carne ovina, pero probablemente, en el mediano y largo plazo, este enfoque podría generalizarse. En este escenario, la inclusión de sistemas de trazabilidad completa «del animal al plato» podría ser una plataforma estratégica para promover una cadena cárnica ovina más competitiva en comparación con otras alternativas de consumo de proteína animal.

\section{BIBLIOGRAFÍA}

ABвотT, P. 2003. Towards more socially responsible cocoa trade. International Agricultural Trade Research Consortium, working paper 03-3. Available from: http,//www.iatrcweb.org. 
ACEBRÜN, L.D.; DOPICO, D.C. 2000. The importance of intrinsic and extrinsic cues to expected and experienced quality: an empirical application for beef. Food Quality and Preference, 11, 220-238.

ÅDNøY, T.; HAUG, A.; SøRHEIM, O.; THOMASSEN, M.S.; VARSZEGI, Z.; EIK, L.O. 2006. Grazing on mountain pastures - does it affect meat quality in lambs? Livestock Production Science, 94, 25-31.

AGRICULTURE AND AGRI-FOOD CANADA. 2011. Global Halal Food Market: May 2011. Available from: http://www.atssea.agr.gc.ca/inter/pdf/4352-eng.pdf.

ALBENZIO, M.; MARINO, R.; CAROPRESE, M.; SANTILLO, A.; ANNICCHIARICO, G.; SEVI, A. 2004. Quality of milk and of Canestrato pugliese cheese from ewes exposed to different ventilation regimens. Journal of Dairy Research, 71,434-443.

ALBENZIO, M.; SANTILLO, A.; CAROPRESE, M.; MARINO, R.; CENTODUCATI, P.; SEVI, A. 2005. Effect of different ventilation regimens on ewes' milk and Canestrato Pugliese cheese quality in summer. Journal of Dairy Research, 72, 447-455.

ALEXANDER, G.; STEVENS, D.; KILGOUR, R.; DE LANGEN, H.; MOTTERSHEAD, B.E.; LYNCH, J.J. 1983. Separation of ewes from twin lambs: incidence in several sheep breeds. Applied Animal Ethology, 10, 301-317.

ALFNES, F. 2004. Stated preferences for imported and hormone-treated beef: application of a mixed logit model. European Review of Agricultural Economics, 31, 19-37.

ALFONSO, M.; SAÑUDO, C.; PARDOS, J.J.; FISHER, A.; SIERRA, I. (2000). Aceptabilidad de la carne de diferentes tipos ovinos europeos valorada por consumidores españoles. Pequeños Rumiantes, 1(1), 18-24.

ÁlVAREZ, I.; DE LA FUENTE, J.; DÍAZ, M.T.; CAÑEQUE, V. 2007. Composición en ácidos grasos y vitamina $\mathrm{E}$ de la carne de cordero alimentados con niveles diferentes de concentrado. Montossi y Sañudo (eds.).Cooperación Hispano Uruguaya. Diferenciación y valorización de la carne Bovina y Ovina del Uruguay en Europa - influencia de sistemas de producción sobre bienestar animal, atributos sensoriales, aceptabilidad, percepción de consumidores y salud humana. INIA Serie Técnica $N^{\circ} 168,61-65$.

AHMED, Q.A.; ARABI, Y.M.; MEMISH, Z.A. 2006. Health risks at the Hajj. Review. www.thelancet.com, 367, 1008-1015.

ANGOOD, K.M.; WOOD, J.D.; NUTE, G. R.; WHITTINGTON, F.M.; HUGHES, S.I.; SHEARD, P.R. 2008. A comparison of organic and conventionally-produced lamb purchased from three major UK supermarkets: Price, eating quality and fatty acid composition. Meat Science, 78, 176-184.

ARELOVICH, H.M.; BRAVO, R.D.; MARTÍNEZ, M.F. 2011. Development, characteristics, and trends for beef cattle production in Argentina. Animal Frontiers, 1, 37-45.

ATKINS, K.D. 2010. Precision sheep management-exploiting the differences between sheep. Maxwell, D. (Ed.) «2010 sheep focus» (Sheep CRC). Available from http://www.sheepcrc.org.au/files/ pages/information/publications/2010sheep-focus-magazine.

AUROUSSEAU, B.; BAUCHART, D.; CALICHON, E.; MICOL, D.; PRIOLO, A. 2004. Effect of grass or concentrate feeding systems and rate of growth on triglyceride and phospholipids and their fatty acids in the $M$. Longissimus thoracis of Lambs. Meat Science, 66, 531-541.

BANCHERO, G.; QUINTANS, G.; LINDSAY, D.R.; MILTON, J.T.B. 2009. A pre-partum lift in ewe nutrition from a high-energy lick or maize or by grazing Lotus uliginosus pasture, increases colostrum production and lamb survival. Animal, 3, 1183-1188.

BANCHERO, G.; QUINTANS, G.; VÁZQUEZ, A.; GIGENA, F.; LA MANNA, A.; LINDSAY, D.R.; MILTON, J.T.B. 2007. Effect of supplementation of ewes with barley or maize during the last week of pregnancy on colostrum production. Animal, 1, 625 -630.

BANCHERO, G.; VÁZQUEZ, A.; MONTOSSI, F.; DE BARBIERI I.; QUINTANS, G. 2010. Prepartum shearing of ewes under pastoral conditions improves the early vigour of 
both single and twin lambs. Animal Production Science, 50, 309-314.

BANKS, R.G. 2003. The Australian prime lamb industry development program 19852003 - coordinated investment in research, development, implementation and marketing, bringing an industry to life. Occasional paper for Meat and Livestock Australia, North Sydney, New South Wales, Australia.

BANKS, R.G., Y ROSS, I.S. 2003. Information flow in lamb supply chains - implications for terminal sire breeding. Proceedings of the $15^{\text {th }}$ conference of the Association for the Advancement of Animal Breeding and Genetics, 334-337.

BARLOW, R.S.; GOBIUS, K.S.; DESMARCHELIER, P. 2006. Shiga toxin producing Escherichia coli in ground beef and lamb cuts: results of a one-year study. International Journal of food Microbiology, 111,1-5.

BEH, K.J.; MADDOX, J.F. 1996. Prospects for development of genetic markers for resistance to gastrointestinal parasite infection in sheep. International Journal for Parasitology. Vol.26, Issues 8-9, August-September 1996, 879-897.

BERCKMANS, D. 2004. Automatic on-line monitoring of animals by precision livestock farming. Proceedings of the ISAH Conference on Animal Production in Europe: The Way Forward in a Changing World, 1, 27-31.

BERGEAUD-BLACKLER, F.; BONNE, K. 2007. D'une consommation occasionnelle à un régime Halal: quelles conséquences sur la santé. Migrations Santé, 124.

BERGEAUD-BLACKLER, F.; EVANS, A. 2010. Final report consumer and consumption issues. Halal and Kosher consumers focus groups results. Dialrel Project. Available from: http://www.dialrel.eu/ images/report-consumption.pdf.

BERNABÉU, R.; TENDERO, A. (2005). Preference structure for lamb meat consumers. A Spanish case study. Meat Science, 71, 464-470.

BERNUÉS, A.; OLAIZOLA, A.; CORCORAN, K. 2003a. Extrinsic attributes of red meat as indicators of quality in Europe: an application for market segmentation. Food Quality and Preference, 14, 265-276.
BERNUÉS, A.; OLAIZOLA, A.; CORCORAN, K. 2003b. Labelling information demanded by European consumers and relationships with purchasing motives, quality and safety of meat. Meat Science, 65, 1095-1106.

BEVERIDGE, W.I.B. 1984. The origin and early history of the mules operation. Australian Veterinary Journal, 61, 161-163.

BIESALSKI, H.K. 2005. Meat as component of a healthy diet - are there any risks or benefits if meat is avoided in the diet? Meat Science, 70, 509-524.

BISHOP, S.C.; MORRIS, C.A. 2007. Genetics of disease resistance in sheep and goats. Small Ruminant Research, 70, 48-59.

BLACHE, D.; FERGUSON, D. 2005. Boost lamb survival-select for calm ewes. 2005. Agribusiness Sheep Updates. Australia.

BLAS, P.; MORAND-FEHR, P. 2000. Effects of nutritional factors on fatty acid composition of lamb deposits. Livestock Production Science, 64, 61-79.

BLASCO, A. 2008. The role of genetic engineering in livestock production. Livestock Science, 113, 191-201.

BLOKHUIS, H.J.; JONES, R.B.; GEERS, R.; MIELE, M.; VEISSIER, I. 2003. Measuring and monitoring animal welfare, Transparency in the food product quality chain. Animal Welfare, 12(4), 445-455.

BOIVIN, X.; NOWAK, R.; LE NEINDRE, P.; TOURNADRE, H. 1997. Discrimination between shepherds by lambs reared under artificial conditions. Journal of Animal Science, 75, 2892-2898.

BONNE, K.; VERBEKE, W. 2008a. Religious values informing Halal meat production and the control and delivery of Halal credence quality. Agriculture and Human Values, 25, 35-47.

BONNE, K.; VERBEKE, W. 2008b. Muslim consumer trust in Halal meat status and control in Belgium. Meat Science, 79, 113-123.

BONNE, K.; VERMEIR, I.; VERBEKE, W. 2009. Impact of Religion on Halal Meat Consumption Decision Making in Belgium. Journal of International Food y Agribusiness Marketing, 21, 5-26. 
BOWEN, M.K.; PEPPER, P.M.; MCPHIE, R.C.; WINTER, M.R. 2009. Evaluation of a remote drafting system for regulating sheep access to supplement. Animal Production Science, 49, 248-252.

BOWEN, M.K.; RYAN, M.P.; JORDAN, D.J.; BERETTA, V.; KIRBY, R.M.; STOCKMAN, C.; MCINTYRE, B.L.; ROWE, J.B. 2006. Opportunities for the Australian sheep industry. In Cronjé, y Maxwell, D.K. (Eds.), Proceedings of the 2006 Australian Sheep Industry CRC Conference, Wool meets Meat-Tools for a Modern Sheep Enterprise-, 134-150.

BRAY, A.R.; GONZALEZ-MACUER, E. 2010. New Zealand sheep and wool industries. In Cottle, D.J. (Ed), International Sheep and Wool Handbook (pp. 73-84). Nottimgham University Press.

BROOM, D.M. 2010. Animal Welfare: An Aspect of Care, Sustainability, and Food Quality Required by the Public. Animal Welfare in Education and Research. Journal of Veterinary Medical Education, 37, 83-88.

CAMPO, M.M.; RESCONI, V.; MUELA, E.; OLIVÁN, A.; SAÑUDO, C. 2009. Influence of cooking method on the fatty acid composition of edible lamb. $55^{\text {th }}$ ICOMST Congress, Copenhagen, Demark.

CAMPO, M.M.; SANTALIESTRA A.M.; P. DE LARA, FLETA J.; C. SAÑUDO Y MORENO, LOS ÁNGELES 2008.El cordero en la dieta española. Alimentación, Nutrición y Salud 15(2), 54-59.

CAÑEQUE, V.; DÍAZ, M.T.; ÁLVAREZ, I.; SAÑUDO, C.; OLIVER, M.A.; MONTOSSI, F.; DE LA FUENTE, J. 2008. Fatty acid composition and vitamin $E$ content of lamb fed with different levels of concentrate on a pasture feeding system. $54^{\text {th }}$ International Congress of Meat Science y Technology, South Africa.

CHAMBERS, S.; LOBB, A.; BUTLER, L.; HARVEY, K.,B.; TRAIL, W. 2007. Local, national and imported foods: A qualitative study. Appetite, 49, 208-213.

CHRISTOPH, I.B.; BRUHN, M.; ROSSEN, J. (2008). Knowledge, attitudes towards and acceptability of genetic modification in Germany. Appetite, 51, 58-68.

CHIUMENTI, R. 1987. Costruzioni rurali. Edagricole, Bologna, Italy.
CIAPPESONI, G.; GIMENO, F. D.; CORONEL, 2011. Evaluaciones genéticas en ovinos: situación actual y desafíos futuros. $X V$ Congreso Latinoamericano de Buiatría. XXXIX Jornadas Uruguayas de Buiatría. 8-10 Junio 2011 Paysandú, Uruguay. ISSN 1688-6.674.197-201.

CIAPPESONI, G.; NAVAJAS, E.A.; SAN JULIÁN, R.; BRITO, G.; GIMENO, D.; GOLDBERG, V. 2012. Variabilidad genética de la calidad de la canal y carne de la raza Texel bajo condiciones de pastoreo. Proceedings of $4^{\text {th }}$ International Conference on genética cuantitativa. Edimburgo del 17 al 22 de junio de 2012, 323. Disponible en: http:// www.icqg2012.org.uk/ .

CODEX ALIMENTARIUS COMMISSION, COMMITTEE ON FOOD HYGIENE. 1991. Draft principles and application of the Hazard analysis Critical Control Points (HACCP) system. Alinorm 93/13. Appendix VI Food and Agriculture Organisation/World Health Organisation.

COFF, C.; KORTHALS, M.; BARLING, D. 2008. Ethical traceability and informed food choice». Coff, C., Barling, D., Korthals, M., y Nielsen, T. (Eds.). Ethical Traceability and Communicating Food: The International Library of Environmental, Agricultural and Food Ethics, 15, 1-22.

CORCORAN, K.; BERNUÉS A.; MANRIQUE E.; PACCHIOLIT.; BAINES R.; BOUTONNET J.P. 2001. Current consumer attitudes towards lamb and beef in Europe. Available from: http://ressources.ciheam.org/om/pdf/a46/ 01600115.pdf

COTTLE, D.J. 2010. Australian sheep and wool industries. Cottle, D.J. (Ed), International Sheep and Wool Handbook (pp. 49-72). Nottimgham University Press.

COWAN, C. 1998. Irish and European consumers views on food safety. Journal of Food Safety, 18, 275-295.

COOPERATIVE RESEARCH CENTRE-CRC 2013a. Precision pays. Australian Sheep Industry Cooperative Research Centre (CRC). Available from: http:// www.sheepcrc.org.au/.

COOPERATIVE RESEARCH CENTRE-CRC (2013b). Precision Sheep Management. Glovebox Guide. Australian Sheep Industry Cooperative Research Centre 
(CRC). Available from: http:// www.sheepcrc.org.au/.

D'ALESSANDRO, A.G.; MAIORANO, G.; KOWALISZYN, B.; LOIUDICE, P.; MARTEMUCCI, G. 2012. How the nutritional value and consumer acceptability of suckling lambs meat is affected by the maternal feeding system. Small Ruminant Research, 106, 83-91.

DAVIDSON, A.; SCHRÖDER, M.J.A.; BOWER, J.A. 2003. The importance of origin as a quality attribute for beef, Results from a Scottish consumer survey. International Journal of Consumer Studies, 27, 91-98.

DEL CAMPO, M. 2008.Bienestar animal y calidad de la carne de novillos uruguayos con diferentes sistemas de terminación y condiciones pre faena.Tesis Doctoral. DPCA Universidad Politécnica de Valencia.Valencia, España. 197 p.

DEL CAMPO, M. 2010. Bienestar Animal y calidad de carne: avances de la Investigación en Uruguay. Seminario de procedimientos de Calidad de Carne. INIA Uruguay, Setiembre de 2010.

DEL CAMPO, M. 2011. La competitividad del sector ganadero uruguayo. ¿Qué rol cumple el estudio del comportamiento animal. Proceedings de JUCA 3, Terceras Jornadas Uruguayas de Comportamiento Animal. Montevideo, Uruguay.

DEL CAMPO, M. 2012. La Investigación en Bienestar Animal en Uruguay: avances del conocimiento científico en bovinos y ovinos. Actas del Seminario Internacional de Bienestar Animal y 2do Encuentro Regional de Investigadores en Bienestar Animal. Montevideo, Uruguay.

DEL CAMPO, M.; MONTOSSI, F. 2007. Oportunidades y Desafíos del Bienestar Animal en Uruguay. Bienestar Animal: el caso de Uruguay. Actas del I Congreso Internacional sobre Bienestar Animal: «Nuevos desafíos para el siglo XXI. Montevideo, Uruguay.

DELGADO, C.L. 2003. Rising consumption of meat and milk in developing countries has created a new food revolution. Journal of Nutrition, 133(1), 3907S3910 S.

DERVISHI, E.; JOY, M.; ALVAREZ-RODRIGUEZ, J.; SERRANO, M.; CALVO, J.H. 2011. The forage type (grazing versus hay pasture) fed to ewes and the lamb sex affect fatty acid profile and lipogenic gene expression in the longissimus muscle of suckling lambs. Journal of Animal Science, 90, 54-66.

DEPARTMENT OF HEALTH. 1994. Report on health and social subjects. No 46. Nutritional aspects of cardiovascular disease. London:HMSO.

DESMARCHELIER, P.; FEGAN, N.; SMALE, N.; SMALL, A. 2007. Managing safety and quality through the red meat chain. Meat Science, 77, 28-35.

DÍAZ, M.T.; ALVAREZ, I.; DE LA FUENTE, J.; SAÑUDO, C.; CAMPO, M.M.; OLIVER, M.A.; FONT I FURNOLS, M.; MONTOSSI, F.; SAN JULIÁN, R.; NUTE, G.R.; CAÑEQUE, V. 2005. Fatty acid composition of meat from typical lamb production systems of Spain, United Kingdom, Germany and Uruguay. Meat Science, 7, 256-263.

DÍAZ, M.T.; VELASCO, S.; CAÑEQUE, V.; LAUZURICA, S.; RUIZ DE HUIDOBRO, F.; PÉREZ, C.; GONZÁLEZ, J.; MANZANARES, C. 2002. Use of concentrate or pasture for fattening lambs and its effect on carcass and meat quality. Small Ruminant Research 43(3), 257-268.

DICKSON, I.A.; STEPHENSON, D.E. 1979. The housing of ewes. West of Scotland Agricultural College, Auchincruive, Scotland, Technical Note $N^{\circ} 63$.

DINDYAL, S.; DINDYAL, S. 2003. How personal factors, including cultural and ethnicity, affect the choices and selection of food we make. The Internet Journal of Third World Medicine, 1. DOI: 10.5580/2231

DRANSFIELD, E.; MARTIN, J.F.; FISHER, A.; NUTE, G.R.; ZYGYIANNIS, D.; STAMATARIS, C.; THORKELSSON, G; VALDIMARSDÓTTIR, T.; PIASENTIER, E.; MILLS, C.; SAÑUDO, C.; ALFONSO, M. 2000. Home placement testing of lamb conducted in six countries. Journal of Sensory Studies, 15, 421-436.

DUCKETT, S.K.; KUBER, P.D. 2001. Genetic and nutritional effects on lamb flavor. Journal of Animal Science E, 79 (Suppl), E249E259.

DU PLESSIS, H.J.; DU RAND, G.E. 2012. The significance of traceability in consumer decision making towards 
Karoo lamb. Food Research International, 47, 210-217.

ENSER, M.; HALLETT, K.G.; HEWETT, B.; FURSEY, G.A.J.; WOOD, J.D.; HARRINGTON, G. 1998. Fatty acid content and composition of UK beef and lamb muscle in relation to production system and implications for human nutrition. Meat Science, 49, 329-341.

FAHRENKRUG, S.C.; BLAKE, A.; CARLSON, D.F.; DORAN, T.; VAN EENENNAAM, A.; FABER, D.; GALLI, C.; GAO, Q.; HACKETT, P.B.; LI, N.; MAGA, E.A.; MUIR, W.M.; MURRAY, J.D.; SHI, D.; STOTISH, R.; SULLIVAN, E.; TAYLOR, J.F.; WALTON, M.; WHEELER, M.; WHITELAW, B.; GLENN, B.P. 2010. Precision genetics for complex objectives in animal agriculture. Journal of Animal Science, 88, 2530-2539.

FAOSTAT. 2007. Available from: http:// faostat.fao.org/site/377/default.aspx.

FARIS, W.F. 2003. Religion and Lamb Consumption. Available from: http:// www.apsc.vt.edu/extension/sheep/ programs/shepherds-Symposium/ 2003/04_religion_lamb_consumption. pdf.

FISHER, A. (2011). Addressing pain caused by mulesing in sheep. Applied Animal Behavioral Science, 135, 232-240.

FISHER, A.V.; ENSER, M.; RICHARDSON, R.I.; WOOD, J.D.; NUTE, G.R.; KURT, E.; SINCLAIR, L.A.; WILKINSON, R.G. 2000. Fatty acid composition and eating quality of lamb types derived from four diverse breed x production systems. Meat Science, 55, 141-147.

FITZPATRICK, J.; SCOTT, M.; NOLAN, A. 2006. Assessment of pain and welfare in sheep. Small Ruminant Research, 62(1-2), 55-61.

FONT I FURNOLS, M.; REALINI, C.E.; GUERRERO, L.; OLIVER, M.A.; SAÑUDO, C.; CAMPO, M.M.; NUTE, G.R.; CAÑEQUE, V.; ÁLVAREZ, I.; SAN JULIÁN, R.; LUZARDO, S.; BRITO, G.; MONTOSSI, F. 2009. Acceptability of lamb fed on pasture, concentrate or combinations of both systems by European consumers. Meat Science, 81, 196-202.

FONT I FURNOLS, M.; REALINI, C.; MONTOSSI, F.; SAÑUDO, C.; CAMPO, M.M.; OLIVER, M.A.; NUTE, G.R.; GUERRERO, L. 2011.
Consumer's purchasing intention for lamb meat affected by country of origin, feeding system and meat price: A conjoint study in Spain, France and United Kingdom. Food Quality and Preference, 22, 443-451.

FONT I FURNOLS, M.; SAN JULIÁN, R.; GUERRERO, L.; SAÑUDO, C.; CAMPO, M.M.; OLLETA, J.L.; OLIVER, M.A.; CAÑEQUE, V.; ÁLVAREZ, I.; DÍAZ, M.T.; BRANSCHEID, W., WICKE, M., NUTE, G.R.; MONTOSSI, F. 2006. Acceptability of lamb meat from different producing systems and aging time to German, Spanish and British consumers. Meat Science, 72, 545-554.

FOOD AND AGRICULTURE ORGANIZATION OF THE UNITED NATIONS (FAO). 2011. World Livestock 2011 - Livestock in food security. Rome: FAO.

FOODANDAGRICULTUREORGANIZATIONOFTHE UNITED NATIONS (FAO). 2012. OECD-FAO Agricultural Outlook 2012-2021.

FOOD STANDARDS AUSTRALIA AND NEW ZEALAND 2004. Initial Assessment Report of Proposal 293 Nutrition, Health and Related Claims, Canberra, Australia.

FRASER, D. 2008. Toward a global perspective on farm animal welfare. Applied Animal Behaviour Science, 113, 330-339.

FRASER, M.D.; SPEIJERS, M.H.M.; THEOBALD, V.J.; FYCHAN, R.; JONES, R. 2004. Production performance and meat quality of grazing lamb finished on red clover, lucerne or perennial ryegrass swards. Grass and Forage Sciences, 59, 345-356.

FREWER, L.J.; HOWARD, C.; SHEPHERD, R. 1997. Public Concerns in the United Kingdom about General and Specific Applications of Genetic Engineering: Risk, Benefit, and Ethics. Science, Technology, and Human Values, 22(1), 98-124.

GALYEAN, M.L.; PONCE, C.; SCHUTZ, J. 2011. The future of beef production in North America. Animal Frontiers, 1, 29-36.

GARDNER, G.E.; PETHICK, D.W.; HOPKINS, D L.; HEGARTY, R.S.; CAKE, M.A.; BOYCE, M.D.; ALLINGHAM, P.G. 2006. The impact of carcase estimated breeding values on yield and quality of sheep meat. Cronjé, 
P.B., y Maxwell, D. (Eds.). Wool meets meat-Tools for a modern sheep enterprise. Proceedings of the 2006 Australian Sheep Industry CRC conference, Orange, Australia, 49-56.

GARNIER, J.P.; KLONT, R.; PLATOW, G. 2003. The potential impact of current animal research on the meat industry and consumer attitudes towards meat. Meat Science, 63, 79-88.

GEDE PUTU, I. 1990. Maternal behaviour in Merino ewes during the first two days after parturition and survival of lambs. Ph.D. Thesis, the University of Western Australia.

GIVENS, D.J.; GIBBS, R.A. 2008. Current intake of EPA and DHA in European populations and the potential of animal-derived foods to increase them. Proceedings of the Nutrition Society, 67, 273-280.

GRAHAM, M.J.; KENT, J.E.; MOLONY, V. 1997. Effects of four analgesic treatments on the behavioural and cortisol responses of 3-week-old lambs to tail docking. The Veterinary Journal, 153, 87-97.

GRIFFIN C.L.; ORCUTT M.W.; RILEY R.R.; SMITH G.C.; SAVELL J.W.; SHELTON M. 1992. Evaluation of palatability of lamb, mutton and chevron by sensory panels of various cultural backgrounds. Small Ruminant Research, 8, 67-74.

GRUNERT, K.G. 2005. Food quality and safety: consumer perception and demand. European Review of Agricultural Economics, 32(3), 369-391.

GRUNERT, K.G. 2006. Future trends and consumer lifestyles with regard to meat consumption. Meat Science, 74(1), 149-160.

GRUNERT, K.G.; BREDAHL, L.; BRUNS $\emptyset$, K. 2004. Consumer perception of meat quality and implications for product development in the meat sector - a review. Meat Science, 66, 259-272.

GRUNERT, K.G.; VALLI, C. 2001. Designer-made meat and dairy products, Consumer-led product development. Livestock Production Science, 72(1-2), 83-98.

GUNN, R.G. 1983. The influence of nutrition on the reproductive performance of ewes. W. Haresign (Ed.), Sheep Production. Butterworths, London, pp. 99-I IO.
HAIGH, R. 2010. A producer's experience with precision sheep management. In Waters, C, y Garden, D. (Eds.) «Adapting mixed farms to future environments»$25^{\text {th }}$ Annual Conference of The Grassland Society of NSW, 57-60.

HARBIGE, L.S. 2003. Fatty acids, the immune response and autoimmunity: $A$ question of $n-6$ essentiality and the balance between n-6 and n-3. Lipids, 38(4), 323-341.

HARPER, G.C.; HENSON, S.J. 2001. The level of consumer concern about animal welfare. The comparative report. The University of Reading, UK. EU Fair CT98-3678.

HARTUNG, J. 1989. Practical aspects of aerosol sampling in animal houses. C.M. Wathes and R.M. Randall (Eds.) Aerosol sampling in Animal Houses. European Community Commission Publications, Luxembourg, 14-23.

HEMSWORTH, P.H.; COLEMAN, G.J. 1998. Human-Livestock Interactions: The stockperson and the Productivity and Welfare of Intensively-farmed Animals. $C A B$ International, Oxon, UK.

HERSLETH, M.; N/ES, T.; RØDBOTTEN, M.; LIND, V.; MONTELEONE, E. 2012. Lamb meatImportance or origin and grazing system for Italian and Norwegian consumers. Meat Science, 90, 899-907.

HOSIE, B.D.; CARRUTHERS, J.; SHEPPARD, B.W. 1996. Bloodless castration of lambs: results of a questionnaire. British Veterinary Journal, 152, 47-55.

HOWE, G.R.; ARONSON, K.J.; BENITO, E. 1997. The relationship between dietary fat intake and risk of colorectal cancer: evidence from the combined analysis of 13 case control studies. Cancer causes control, 8, 215-228.

HOWE, P.; MEYER, B.; RECORD, S.; BAGHURST, K. 2006. Dietary intake of long-chain w3 polyunsaturated fatty acids: contribution of meat sources. Nutrition 22, 47-53.

HUNTER, D.J.; SPIEGELMAN, D.; ADAMI, H.O. 1996. Cohort studies of fat intake and the risk of breast cancer: a pooled analysis. The New England Journal of Medicine, 334, 356-361. 
HUSSAINI, M.M. 1993. Halal Haram lists. Why they do not work? Available from: http:// www.soundvision.com/info/Halalhealthy/ Halal.list.asp.

ISLAMIC FOOD AND NUTRITION COUNCIL OF AMERICA . IFANCA. 2012. White Paper: Halal Boosts US Economy y Exports. Available from: http://www.ifanca.org/ cms/wpages/detail/502136ab-9fdc4233-9b85-23b83239ea6a.

IMAMI, D.; CHAN-HALBRENDT, C.; ZHANG, Q.; ZHLLIMA, E. 2011. Conjoint analysis of consumer preferences for lamb meat in central and southwest urban Albania. International Food and Agribusiness Management Review, 14, 111-126.

INSTITUTO INTERAMERICANO DE COOPERACIÓN PARA LA AGRICULTURA. IICA (2009). La Experiencia de Uruguay en Trazabilidad Bovina. MGAP, INAC, IICA. ISBN 13: 978-929248-137-7. Diciembre, 2009. Montevideo. Uruguay.

JACQUES, J.; BERTHIAUME, R.; CINQ-MARS, D. 2011. Growth performance and carcass characteristics of Dorset lambs fed different concentrates: Forage ratios or fresh grass. Small Ruminant Research, 95(2-3), 113-119.

JAMORA, J.J.; RHEE, K.S. 1998. The uniqueness of lamb: nutritional and sensory properties. Sheep and Goat Research Journal, 14, 53-64.

JEREMIAH, L.E. 1988. A comparison of flavour and texture profiles for lamb roasts from three different geographical sources. Canadian Institute of Food Science and Technology Journal, 21, 471-476.

JOHNSON C.B.; SYLVESTER, S.P.; STAFFORD, K.J. 2009. Effects of age on the electroencephalographic response to castration in lambs anaesthetised using halothane in oxygen from birth to six weeks old. Veterinary Anaesthesia and Analgesia, 36, 273-279.

JONES, P.; COMFORT, D.; HILLER, D. 2003. Retailing fair trade food products in the UK. British Food Journal, 105, 800-810.

JOY, M.; SANZ, A.; RIPOLL, G.; PANEA, B.; RIPOLL-BOSCH, R.; BLASCO, J.; ALVAREZ-RODRIGUEZ, J. 2012. Does forage (grazing vs. hay) fed to ewes before and after lambing affect suckling lambs performance, meat quality and consumer purchase intention? Small Ruminant Research, 104, 1-9.

JURIC, B.; WORSLEY, A. 1998. Consumers' attitudes towards imported food products. Food Quality and Preference, 9 (6), 431-441.

KARLSSON, L.J.E.; GREEF, J.C. 2012. Genetic aspects of sheep parasitic diseases. Veterinary Parasitology, 189, 104-112.

KAYNAK, E.; KUCUKEMIROGLU, O.; HYDER, A.S. 2000. Consuemrs' country-of-origin (COO) perceptions of imported products in a homogenous less-developed country. European Journal of Marketing, 34 (9/10), 1221-1241.

KEMP, J.D.; MAHYUDDIN, M.; ELY, D.G.; FOX, J.D.; MOODY, W.G. 1981. Effect of feeding system, slaughter weight and sex on organoleptic properties, and fatty acid composition of lamb. Journal of Animal Science, 51, 321-330.

KENT, J.E.; MOLONY, V.; GRAHAM, M.J. 1998. Comparison of methods for the reduction of acute pain produced by rubber ring castration or tail docking of week-old lambs. The Veterinary Journal, 155, 39-51.

KENT, J.E.; MOLONY, V.; JACKSON, R.E.; HOSIE, B.D. 1999. Chronic inflammatory responses of lambs to rubber ring castration: are there any effects of age or size of lamb at treatment? p. 160-162. Russel, A.J.F., Morgan, C.A., Savory, C.J., Appleby, M.C., Lawrence, T.L.J. (Eds.). Farm animal welfare-who writes the rules? British Society of Animal Science. 23 Edition.

KNIGHT, A.J. 2009. Perceptions, knowledge and ethical concerns with GM foods and the GM process. Public Understanding Science, 18, 177-188.

LACA, E. 2009a. New Approaches and Tools for Grazing Management. Rangeland Ecology and Management, 62, 407-417.

LACA, E. 2009b. Precision Livestock Production: tools and concepts. Revista Brasileira de Zootecnia, 38, 123-132.

LE NEINDRE, P.; BOIVIN, X.; BOISSY, A. 1996. Handling of extensively kept animals. Applied Animal Behaviour Science, 49, 73-81. 
LEVER, J.; MIELE, M. 2012. The growth of Halal meat markets in Europe: An exploration of the supply side theory of religion. Journal of Rural Studies, 28, 528-537.

LEWIS, R.M.; SIMM, G.; DINGWALL, W.S.; MURPHY, S.V. 1996. Selection for lean growth in terminal sire sheep to produce leaner crossbred progeny. Animal Science, 63, 133-142.

LEWIS, R M.; VAN HEELSUM, A.M.; HARESIGN, W.; DAVIES, M.H.; ROEHE, R.; BUNGER, L.; SIMM, G. 2006. Role of sire referencing schemes in terminal sire sheep to improve carcass quality in crossbred lambs. Journal of Animal Science, 84 (Suppl. 1), 618.

LEYMASTER, K.A.; SHACKELFORD, S.D.; WHEELER, T.L.; KOOHMARAIE, M. 2006. Breed effects on growth, carcass and meat quality traits of sheep. Proceedings of the British Society of Animal Science, New developments in Sheepmeat Quality, 43-47.

LINDSAY, D.R.; NOWAK, R.; GEDE PUTU, I.; MCNEILL, D. 1990. Behavioural interactions between the ewe and her young at parturition: a vital step for the lamb. Oldham, C.M., Martin, G.B. y Purvis, I.W. (Eds.), Reproductive Physiology of Merino Sheep. Concepts and Consequences, 191-206.

LOURENÇO, M.; VAN RANST, G.; DE SMET, S.; RAES, K.; FIEVEZ, V. 2007. Effect of grazing pastures with different botanical composition by lambs on rumen fatty acid metabolism and fatty acid pattern of longissimus muscle and subcutaneous fat. Animal, 1, 537-545.

LOYNES, I.J. 1983. Sheep house design. Housing Sheep. Farm Buildings Information Centre. Kenilworth, Stoneleigh, UK.

MACFARLANE, J. M.; SIMM, G. 2007. The contribution of genetic improvement for lamb meat production. Paper presented at 3rd International Symposium about Goat and Sheep Meat Type-3rd SINCORTE. João Pessoa, Paraiba, Brazil.

MARÍA, G.A. 2006. Public perception of farm animal welfare in Spain. Livestock Science, 103, 250-256.

MARKOWITZ, T.M.; DALLY, M.R.; GURSKY, K.; PRICE, E.O. 1998. Early handling increases lamb affinity for humans. Animal Behaviour, 55, 573-587.

MARTINEZ CEREZO S.; SAÑUDO C.; PANEA B.; OLLETA J.L. 2005. Breed, slaughter weight and ageing time effects on consumer appraisal of thee muscles of lamb. Meat Science, 69, 797-805.

MCAFFEE, A.J.; MCSORLEY, E,M.; CUSKELLY, G.J.; FEARON, A.M.; MOSS, B.W.; BEATTIE, J.A. M.; WALLACE, J.M.W.; BONHAM M.P.; STRAIN, J.J. 2011. Red meat from animals offered a grass diet increases plasma and platelet n-3 PUFA in healthy consumers. British Journal of Nutrition, 105, 80-89.

MCAFEE, A.J.; MCSORLEY, E.M.; CUSKELLY, G.J.; MOSS, B.W.; WALLACE, J.M.W.; BONHAM, M.P.; FEARON, A.M. 2010. Red meat consumption: An overview of the risks and benefits. Meat Science, 84, 1-13.

MCEACHERN, D.S.; WILLOCK, J. 2004. Producers and consumers of organic meat: A focus on attitudes and motivations. British Food Journal, 106, 534-552.

MCCARTHY, M.; DE BOER, M.; O'REILLY, S.; COTTER, L. 2003. Factors influencing intention to purchase beef in the Irish market. Meat Science, 65, 1071-1083

MCINERNEY, J. 2004. Animal welfare, economics and policy. Report prepared for DEFRA. Available from: http,// statistics.defra.gov.uk/esg/reports/ animalwelfare.pdf.

MCLAREN, A. 2000. Cloning: pathways to a pluripotent future. Science, 288 (5472), 1775-1780.

MCNEILL, S.; VAN ELSWYK, M.E. 2012. Red meat in global nutrition. Meat Science, 92, 166-173.

MELLOR, D.J. 1983. Nutritional and placental determinants of foetal growth rate in sheep and consequences for the new born lamb. The British Veterinary Journal, 139, 307-324.

MELTON, S.L.1990. Effects of feeds on flavour of red meat: a review. Journal of Animal Science, 68, 4421-4435.

MIELE, M.; EVANS, A. 2010. When food become animals. Ruminations on ethics and responsibility in care-full practices of 
consumption. Ethics, Place $y$ Environment, 13, 171-190.

MILLEN, D.D.; PACHECO, R.D.L.; MEYER, P.M.; MAZZA-RODRIGUES, P.H.; DE BENIARRIGONI, M. 2011. Current outlook and future perspectives of beef production in Brazil. Animal Frontiers, 1, 46-52.

MIRANDA DE LA LAMA, G.; VILLLARROEL, M.; OLLETA, J.L.; ALIERTA, S.; SAÑUDO, C.; MARIA, G. 2009. Effect of the preslaughter logistic chain on meat quality of lambs. Meat Science, 83, 604-609.

MONTOSSI, F.; AYALA, W.; DÍAZ, R. 2008. The challenges of cropping and forestry intensification on grasslands livestock production systems: the Uruguayan case. In: Multifunctional grassland in a changing world. In: XXI International Grassland Congress. Huhhot, China. Vol. II, 5-13.

MONTOSSI, F.; BRITO, G. 2012. Changes in animal production systems in South America: Current and future consequences on carcass and meat quality attributes. Session: Producing niche market fresh meat products. Oral presentation. 58 th 1 COMST. Montreal, Canada, August 12-17, 2012.

MONTOSSI, F.; LUZARDO, S.; SAN JULIÁN, R.; DE BARBIERI, I.; CIAPPESONI, G; BRITO, G. 2007. Evaluación de distintas estrategias de alimentación sobre la performance y la calidad de la canal estimada a través de las mediciones in vivo por ultrasonografía en corderos pesados Corriedale del Uruguay. Montossi y Sañudo (Eds.). Cooperación Hispano Uruguaya. Diferenciación y valorización de la carne Bovina y Ovina del Uruguay en Europa influencia de sistemas de producción sobre bienestar animal, atributos sensoriales, aceptabilidad, percepción de consumidores y salud humana. INIA Serie Técnica N 168 79-90.

MONTOSSI, F.; SAN JULIÁN, R.; BRITO, G.; DE LOS CAMPOS, G.; GANZÁBAL, A.; DIGHIERO, A.; DE BARBIERI, I.; CASTRO, L.; ROBAINA, R.; PIGURINA, G.; DE MATTOS, D.; NOLLA, M. 2003. Producción de carne ovina de calidad con la raza Corriedale: recientes avances y desafíos de la innovación tecnológica en el contexto de la Cadena Cárnica Ovina del Uruguay. Resúmenes del $12^{\circ}$ Congreso Mundial de Corriedale. Montevideo, Uruguay, 74-90.

MONTOSSI, F.; SAÑUDO, c. 2007 a. Antecedentes, justificación y objetivos del Proyecto. Montossi y Sañudo (Eds.). Cooperación Hispano Uruguaya. Diferenciación y valorización de la carne Bovina y Ovina del Uruguay en Europa influencia de sistemas de producción sobre bienestar animal, atributos sensoriales, aceptabilidad, percepción de consumidores y salud humana. INIA Serie Técnica $N^{\circ} 168,9-14$.

MONTOSSI, F.; SAÑUDO, C. 2007b. Conclusiones e implicancias estratégicas del Proyecto. Montossi y Sañudo (Eds.). Cooperación Hispano Uruguaya. Diferenciación y valorización de la carne Bovina y Ovina del Uruguay en Europa - influencia de sistemas de producción sobre bienestar animal, atributos sensoriales, aceptabilidad, percepción de consumidores y salud humana. INIA Serie Técnica $N^{\circ} 168$, 113-116.

MONTOSSI, F.; SILVEIRA, C.; CUADRO, R.; SAN JULIÁN, R.; LUZARDO, S.; BRITO, G.; DEL CAMPO, M. 2009. Can restricted grain supplementation practice under grazing conditions change fatty acid composition in lamb meat? 55th International Congress of Meat Science and Technology (ICOMST). Copenhague, Dinamarca.

MONTOSSI, F.; DE BARBIERI, I.; CIAPPESONI, G.; GANZABAL, A.; BANCHERO, G.; SOARES DE LIMA, J.M.; BRITO, G.; LUZARDO, S.; SAN JULIÁN, R.; SILVEIRA, C.; VÁZQUEZ, A. 2011. ¿Es posible con menos ovejas producir más y con mayor valor agregado?: Análisis y aportes del INIA para una ovinocultura uruguaya más innovadora y competitiva. En: Suplemento El País Agropecuario. Diciembre 2011. pp 30-24.

MORRIS, J.E.; CRONIN, G.M.; BUSH, R.D. 2012. Improving sheep production and welfare in extensive systems trough precision sheep management. Animal Production Science, 52, 665-670. http://dx.doi.org/ 10.1071/AN11097.

MUCCI, A.; HOUGH, G. 2003. Perceptions of genetically modified foods by consumers in Argentina. Food Quality and Preference, 15, 43-51. 
MUELLER, J. 2003. Curso de Capacitación en Mejoramiento Genético de Ovinos. Available from: http://www.biblioteca.org. ar/libros/210338.pdf

MUELLER, J. 2008. Programas de Mejoramiento Genético de Pequeños Rumiantes. CD: III Seminario Sobre Mejoramiento Genético Ovino: Desafíos, Oportunidades y Perspectivas. June 2325, Uruguay.

NAPOLITANO, F., BRAGHIERI, A., CAROPRESE, M., MARINO, R., GIROLAMI, A., Y SEVI, A. 2007a. Effect of information about animal welfare, expressed in terms of rearing conditions, on lamb acceptability. Meat Science, 77(3), 431-436.

NAPOLITANO, F.; BRAGHIERI, A.; PIASENTIER, E.; FAVOTTO, S.; NASPETTI, S.; ZANOLI, R. 2010. Effect of information about organic production on beef liking and consumer willingness to pay. Food Quality and Preference, 21, 207-212.

NAPOLITANO, F.; CAPORALE, G.; CARLUCCI, A.; MONTELEONE, E. 2007b. Effect of information about animal welfare and product nutritional properties on acceptability of meat from Podolian cattle. Food Quality and Preference, 18, 305-312.

NAKYINSIGE, K.; MAN, Y.B.C.; SAZILI, A. Q. 2012. Halal authenticity issues in meat and meat products. Meat Science, 91, 207-214.

NARDONE, A.; ZERVAS, G.; RONCHI, B. 2004. Sustainability of small ruminant organic systems of production. Livestock Production Science, 90, 27-39.

NELSON, C.H. 2001. Risk Perception, Behavior, and Consumer Response to Genetically Modified Organisms: Toward Understanding American and European Public Reaction. American Behavioral Scientist, 44(8), 1371-1388.

NEWHOLM, T.; SHAW, D. 2007. Studying the ethical consumer. A review of research. Journal of Consumer Behaviour, 6 , 253-270.

OBERMILLER, C.; SPANGENBERG, E. 1989. Exploring the effects of country of origin labels: and information processing framework. Advances in Consumer Research, 16, 454-459.
ORR, R.J.; PARSONS, A.J.; PENNING, P.D.; TREACHER, T.T. 1990. Sward composition, animal performance and the potential production of grass/white clover swards continuously stocked with sheep. Grass Forage Science, 45, 325-336.

PARK, R.J.; CORBETT, J.L.; FURNIVAL, E.P. 1972. Flavour differences in meat from lambs grazed in lucerne (Medicagosativa) or phalaris (Phalaristuberosa) pastures. The Journal of Agricultural Sciences, 78, 47-52.

PASCALEV, A. 2003. You Are What You Eat: Genetically Modified Foods, Integrity, and Society. Journal of Agricultural and Environmental Ethics, 16, 583-594.

PAUSELLI, M.; MORBIDINI, L.; LASAGNA, E.; LANDI, V.; GIANGRANDE, R. 2009. Consumer acceptacne of Italian or New Zealander lamb meat: and Italian case study. Italian Journal of Animal Science, 8, 528-530.

PENNING, P.D.; PARSONS, A.J.; ORR, R.J.; TREACHER, T.T. 1991. Intake and behavior response by sheep to changes in sward characteristics under continuous stocking. Grass Forage Science, 46, 15-28.

PETHICK, D.W.; BANKS, R.G.; HALES J.; ROSS, I.R. 2006. Australian prime lamb - a vision for 2020. (Eds.) Cronjé, P.B., y Maxwell, D., Wool meet Meat - Tools for a Modern Sheep EnterpriseProceedings of the 2006 Australian Sheep Industry CRC Conference, Orange, 194-201.

PEW RESEARCH CENTER FORUM ON RELIGION Y PUBLIC LIFE. 2011 .The Future of the Global Muslim Population.Projections for 2010-2013. Available from: http:// www. pewforum.org/the-future-of-theglobal-muslim-population.aspx.

PHILLIPS, C.J.C.; WOJCIECHOWSKA, J.; MENG, J.; CROSS, N. 2009. Perceptions of the importance of different welfare issues in livestock production. Animal, 3(8), 1152-1166.

PIASENTIER, E.; MORGANTE, M.; SACCÀ, E.; VALUSSO, R.; PARENTE, J. 2007. Effect of animal feeding system information on consumer expectation and acceptability of lamb meat. Options Méditerranéennes, Series A, 74, 197-202. 
POINDRON, P.; RAKSYANI, I.; ORGEUR, P.; LE NEINDRE, P. 1984. Comparaison du comportement matemel en bergerie à la parturition chez des brebis primipares ou multipares de race Romanov, Préalpes du Sud et île de France. Genetics Selection Evolution, 16, 503-522.

POMAR, J.; LÓPEZ, V.; POMAR, C. 2011. Agentbased simulation framework for virtual prototyping of advanced livestock precision feeding systems. Computers and Electronics in Agriculture, 78, 88-97.

PONNAMPALAM, E.N.; SINCLAIR, A.J.; EGAN, A.R.; FERRIER, G.R.; LEURY, B.J. 2002. Dietary manipulation of muscle longchain omega- 3 and omega- 6 fatty acids and sensory properties of lamb meat. Meat Science, 60, 125-132.

PRIOLO, A.; MICOL, D.; AGABRIEL, J. 2001. Effects of grass feeding systems on ruminant meat colour and flavour. A review. Animal Research, 50, 185-200.

PRIOLO, A.; MICOL, D.; AGABRIEL, J.; PRACHE, S.; DRANSFIELD, E. 2002. Effect of grass or concentrate feeding systems on lamb carcass and meat quality. Meat Science, $62,179-185$.

PURSER, A.F.; YOUNG, G.B. 1959. Lamb survival in two hill flocks. Animal Production, 1, 85-91.

RAES, K.; DE SMET, S.; DEMEYER, D. 2004. Effects of dietary fatty acids on incorporation of long chain polyunsaturated fatty acids and conjugated linoleic acid in lamb, beef and pork meat: a review. Animal Food Science and Technology, 113, 199-221.

RASSU, S.P.G.; ENNE, G.; LIGIOS, S.; MOLLE, G. 2004. Nutrition and Reproduction. Pulina, G. (Ed.), Dairy Sheep Nutrition. $C A B I$ Publishing. Wallingford, UK, 109-128.

RAY, E.E.; KROMANN, R.P.; COSMA, E.J. 1975. Relationship between fatty acid composition of lamb fat and dietary ingredients. Journal of Animal Science, 41, 1767-1774.

RAYNOLDS, L.T. 2000. Re-embedding global agriculture. The international organic and fair trade movements. Agriculture and Human Values, 17, 297-309.

RESCONI, V.C.; CAMPO, M.M.; FONT I FURNOLS, M.; MONTOSSI, F.; SAÑUDO, C. 2009.
Sensory evaluation of castrated lambs finished on different proportions of pasture and concentrate feeding systems. Meat Science, 83, 31-37.

RICHARDSON, N.J.; MACFIE, H.J.H.; SHEPHERD, R. 1994. Consumer attitudes to meat eating. Meat Science, 36, 57-65.

RIMAL. A. 2005. Meat labels: Consumer attitude and meat consumption pattern. International Journal of Consumer Studies, 29, 47-54.

ROBINSON, J.J.; MCDONALD, L.; MCHATTIE, I.; PENNIE, K. 1978. Studies on reproduction in prolific ewes. 4 sequential changes in maternal body during pregnancy. Journal of Agriculture Science, 91, 291-304.

ROJAS, H.; STUARDO, L.; BENAVIDES, D. (2004). Políticas y prácticas de bienestar animal em los países de América, Estudio preliminar. Revue Scientifique et Technique-Office International des Epizooties, 24(2), 549-565.

ROWAN, T.G. 1992. Thermoregulation in neonatal ruminants. Varley, M.A., Williams, P.E.V., y Lawrence, T.L.J. (Eds.), Neonatal Survival and Growth. Occas. Publ. No.15, British Society of Animal Production, 13-24.

ROWE, J.B. 2006. Opportunities for the Australian sheep industry. Cronjé, $y$ Maxwell, D.K. (Eds), Proceedings of the 2006 Australian Sheep Industry CRC Conference, Wool meets Meat-Tools for a Modern Sheep Enterprise-, 212-220.

ROWE, J.B. 2010. The Australian sheep industry - undergoing transformation. Animal Production Science, 50, 991-997.

ROWE, J.B.; ATKINS, K. D. 2006. Precision sheep production - pipedream or reality? Australian Society of Animal Production $26^{\text {th }}$ Biennial Conference 2006. Short Communication Number 33.

ROWLAND, I.R. 2002. Genetically modified foods, consumers, and the media. Proceedings of the Nutrition Society, 62, 25-29.

RUBINO R.; MORAND-FEHR P.; RENIERI C.; PERAZA C.; SARTI, F.M. 1999. Typical products of the small ruminant sector and the factors affecting their quality. Small Ruminant Research, 34, 289-302. 
SAN JULIÁN, R.; LUZARDO, S.; BRITO, G.; MONTOSSI, F. 2007. Efecto de diversas dietas en las características de la canal y de la calidad de la carne en corderos Corriedale de Uruguay. INIA Uruguay. Serie Técnica, 168, 91-96.

SAÑUDO, C.; ALFONSO, M.; SAN JULIÁN, R.; THORKELSSON,G; VALDIMARSDOTTIR, T.; ZYGOYIANNINS, D.; STAMATARIS, C.; PIASENTIER, E.; MILLS, C.; BERGE, P.; DRANSFIELD, E.; NUTE, G.R.; ENSER, M.; FISHER, A.V. 2007. Regional variation in the hedonic evaluation of lamb meat from diverse production systems by consumers in six European countries. Meat Science, 75, 610-621.

SAÑUDO, C.; ENSER, M.E.; CAMPO, M.M.; NUTE, G.R.; MARIA, G.; SIERRA, I.; WOOD, J.D., 2000. Fatty acid composition and sensory characteristics of lamb carcasses from Britain and Spain. Meat Science, 54, 339-346.

SAÑUDO, C.; NUTE, G.R.; CAMPO, M.M.; MARÍA, G.; BAKER, A.; SIERRA, I.; ENSER, M.E.; WOOD, J.D. 1998. Assessment of commercial lamb meat quality by British and Spanish taste panels. Meat Science, 48(1-2), 91-100.

SAUNDERS, C.; GUENTHER, M.; DRIVER, T. 2010. Sustainability trends in key overseas markets: market drivers and implications to increase value for New Zealand exports. Research Report $\mathrm{N}^{\circ}$ 319. Lincoln University, New Zealand.

SCHILTER, B.; COSNTABLE, A. 2002. Regulatory control of genetically modified (GM) foods: likely developments. Toxicology Letters, 127, 341-349.

SCHNETTLER, B.; RUIZ, D.; SEPÚLVEDA, O.; SEPÚLVEDA, N. 2008. Importance of the country of origin in food consumption in a developing country. Food Quality and Preference, 19, 372-382.

SCHNETTLER B.; VIDAL, R.; SILVA, R.; VALLEJOS, L.; SEPÚLVEDA, N. 2009. Consumer willingness to pay for beef meat in a developing country. The effect of information regarding country of origin, price and animal handling prior to slaughter. Food Quality and Preference, 20, 156-165.

SCHRÖEDER, M.J.A.; MCEACHERN, M.G. 2004. Consumer value conflicts surrounding ethical food purchase decisions, A focus on animal welfare. International Journal of Consumer Studies, 28(2), 168-177.
SCHÖNFELDT, H.C.; GIBSON, N. 2008. Changes in the nutrient quality of meat in an obesity context. Meat Science, 80, 20-27.

SCHÖNFELDT, H.C.; NAUDÉ, R T.; BOK, W.; VAN HEERDEN, S.M.; SOWDEN, L. 1993. Cooking- and juiciness-related quality characteristics of goat and sheep meat. Meat Science, 34, 381-394.

SCHREURS, N.M.; LANE, G.A.; TAVENDALE, M.H.; BARRY, T.N.; MCNABB, W.C. 2008. Pastoral flavour in meat products from ruminants fed fresh forages and its amelioration by forage condensed tannins. Animal Feed Science and Technology, 146, 193-221.

SCOTT, P.R.; DUN, K.; PENNY, C.D.; STRACHAN, W.D.; KEELING, N. 1996. Field assessment of lamb behavior after xylazine hydrochloride epidural injection for castration using rubber rings. AgriPractice, 17, 19.

SEPÚLVEDA, W.S.; MAZA, M.T.; PARDOS, L. 2011. Aspects of quality related to the consumption and production of lamb meat. Consumers versus producers. Meat Science, 87, 366-372.

SEVI, A. 2005. Influence of sunlight, temperature and environment on the fatty acid composition and coagulatine properties of sheep milk. Gabina, D., Le Jaouen, J.C., Pirisi, A., Ayerbe, A., y Soustre, Y. (Eds.). The Future of the Sheep and Goat Dairy Sectors. Special Issue No. 200501/2005. International Dairy Federation, 305-311.

SEVI, A.; ALBENZIO, M.; ANNICCHIARICO, G.; CAROPRESE, M.; MARINO, R.; TAIBI, L. 2002. Effects of ventilation regimen on the welfare and performance of lactating ewes in summer. Journal of Animal Science, 80, 2349-2361.

SEVI, A.; ALBENZIO, M.; MUSCIO, A.; CASAMASSIMA, D.; CENTODUCATI, P. 2003a. Effects of litter management on airborne particulate in sheep houses and on the yield and quality of ewe milk. Livestock Production Science, 81, 1-9.

SEVI, A.; CASAMASSIMA, D.; PULINA, G.; PAZZONA, A. 2009. Factors of welfare reduction in dairy sheep and goats. Review article. Italian Journal of Animal Science, 8 (Suppl. 1), 81-101.

SEVI, A.; MASSA, S.; ANNICCHIARICO, G.; DELL'AQUILA, S.; MUSCIO, A. 1999. Effect of stocking density on ewes milk yield and 
incidence of subclinical mastitis. Journal of Dairy Reserach, 66, 489-499.

SEVI, A.; TAIBI, L.; ALBENZIO, M.; ANNICCHIARICO, G.; MARINO, R.; CAROPRESE, M. 2003b. Influence of ventilation regimen on microenvironment and on ewe welfare and milk yield in summer. Italian Journal of Animal Science, 3, 197-212.

SEVI, A.; TAIBI, L.; ALBENZIO, M.; CAROPRESE, M.; MARINO, R.; MUSCIO, A. 2003C. Ventilation effects on air quality and on the yield and quality of ewe milk in winter. Journal of Dairy Science, 86, 3881-3890.

SEVI, A.; TAIBI, L.; MUSCIO, A.; ALBENZIO, M.; DANTONE, D.; DELL'AQUILA, S. 2001. Quality of ewe milk as affected by stocking density and litter treatment with bentonite. Ital. Journal of Food Science, 13,77-86.

SHARMA, S.; SHIMP, T.A.; SHIN, J. 1995. Consumer ethnocentrism: a test of antecedents and moderators. Journal of the Academy of Marketing Science, 23, 26-37.

SHAW, D.; SHIU, E. 2001. Ethics in consumer choice. A multivariate modelling approach. European Journal of Marketing, 37, 1485-1498.

SHIMP, T.A.; SHARMA, S. 1987. Consumer ethnocentrism: construction and validation of the CETSCALE. Journal of Marketing Research, XXIV, 280-289.

SIMM, G. 1992. Selection for lean meat production in sheep. Speedy, AW., (Ed.), Recent Advances in Sheep and Goat Research, CAB International, 193-215.

SIMM, G. 1994. Developments in improvement of meat sheep. World Congress of Genetics Applied to Livestock Production. Proceedings, Vol. 18, 3-10.

SIMM, G.; DINGWALL, W.S. 1989. Selection indices for lean meat production in sheep. Livestock Production Science, 21, 223-233.

SIMM, G.; LEWIS, R.M.; GRUNDY, B.; DINGWALL, W.S. 2002. Responses to selection for lean growth in sheep. Animal Science, $74,39-50$.

SIMMONS, P.; EKARIUS, C. 2001. Storey's Guide to Raising Sheep. North Adams, MA:
Storey Publishing LLC. ISBN 978-158017-262-2.

SMITH, G.C.; DUTSON, T.R.; HOSTETLER, R.L.; CARPENTER, Z.L. 1976. Fatness, rate of chilling and tenderness of lamb. Journal of Food Science, 41, 748-756.

SMITH, G.C.; TATUM, J.D.; BELK, K.E.; SCANGA, J.A.; GRANDIN, T.; SOFOS, J.N. 2005. Traceability from a US perspective. Meat Science, 71, 174-193.

SNEDDON, J.; ROLLIN, B. 2010. Mulesing and animal ethics. Journal of Agricultural and Environmental Ethics, 23, 371-386.

SPECIAL EUROBAROMETER, EUROPEAN COMMISSION 2005. Attitudes of consumers towards the welfare of farmed animals (p. 138).

SPECIAL EUROBAROMETER, EUROPEAN COMMISSION 2007. Attitudes of EU citizens toward animal welfare (p. 82).

SPECIAL EUROBAROMETER 354 FOR FOODRELATED RISKS. 2010. Report conducted by TNS Opinion y Social at the request of the European Food Safety Authority (EFSA) ISBN: 978-92-9199261-4.

SPEEDY, A.W. 2003. Global production and consumption of animal source foods. Journal of Nutrition, 133, 4048S-4053S.

SPHOR, L.; BANCHERO, G.; CORREA, M.T.M.; OSORIO, G.; QUINTANS, G. 2011. Early prepartum shearing increases milk production of wool sheep and the weight of the lambs at birth and weaning. Small Ruminant Research, 99, 44-47.

STANLEY, J.C.; ELSOM, R.L.; CALDER, P.C.; GRIFFIN, B.A.; HARRIS, S.W.; JEBB, S.A. 2007. UK Food Standards Agency Workshop Report: The effects of dietary n-6:n-3 fatty acid ratio on cardiovascular health. British Journal of Nutrition, 98(6), 1305-1310.

TAYLOR, M.A. 2012. Emerging parasitic diseases of sheep. Vet. Parasitol. 189, 2-7. The Muslims Council of Britain (2013). Available from: http:// www.mcb.org.uk/links/leftmenu1.php.

THORNTON, P.D.; WATERMAN-PEARSON, A.E. 1999. Quantification of the pain and distress responses to castration in young lambs. Research in Veterinary Science, 66(2), 107-18. 
TILMAN, D., CASSMAN, K.G., MATSON, P.A., NAYLOR, R., Y POLASKY, S. 2002. Agricultural sustainability and intensive production practices. Nature, 418, 671-677.

TREACHER, T.T. 1983. Nutrient requirements for lactation in the ewe. Haresign, W. (Ed.), Sheep Production. Butterworths, London, 133-153.

TROY, D.J.; KERRY, J.P. 2010. Consumer perceptions and the role of science in the meat industry. Meat Science, 86, 214-226.

TSOURGIANNIS, L.; KARASAVVOGLOU, A.; FLOROU, G. 2011. Consumers' attitudes towards GM Free products in a European Region. The case of the Prefecture of Drama-Kavala-Xanthi in Greece. Appetite, 57, 448-458.

TURNER, T.D.; KARLSSON, L.; MAPIYE, C.; ROLLAND, D.C.; MARTINSSON, K.; DUGAN, M.E.R. 2012. Dietary influence on the $m$. longissimus dorsi fatty acid composition of lambs in relation to protein source. Meat Science, 91, 472-477.

VÁQUEZ-SALAT, N.; SALTER, B.; SMETS, G.; HOUDEBINE, L.M. 2012. The current state of GMO Governance: Are we ready for GM animals? Biotechnology Advances, 30, 1336-1343.

VAN DER SPIEGEL, M.; VAN DER FELS-KLERX, H.J.; STERRENBURG, P.; VAN RUTH, S.M.; SCHOLTENS-TOMA, I.M.J.; KOK, E.J. 2012. Halal assurance in food supply chains: verification of halal certificates using audits and laboratory analysis. Trends in Food Science and Technology, 27, 109-119.

VERBEKE, W.J. 2003. Consumer perception of food safety: Role and influencing factors, at new approaches to food safety economics. Available from: http:// library.wur.nl/ojs/index.php/frontis/ article/viewFile/989/560.

VERBEKE, W.; PÉREZ-CUETO, F.J.A.; DE BARCELLOS, M.D.; KRYSTALLIS, A.; GRUNERT, K.G. 2010. European citizen and consumer attitudes and preferentes regarding beef and pork. Meat Science, 84(2), 284-292.

VERBEKE, W.; VACKIER, I. 2004. Profile and effects of consumer involvement in freshmeat. Meat Science, 67, 159-168.
VERBEKE, W.; VIANE, J. 1999. Beliefs, attitude and behaviour towards fresh meat consumption in Belgium, Empirical evidence from a consumer survey. Food Quality and Preference, 10(6), 437-445.

VERLEGH, P.W.J.; STEENKAMP, B.E.M. 1999. A review and meta-analysis of country-oforigin research. Journal of Economics Psychology, 20, 521-546.

VERMEIR, I.; VERBEKE, W. 2006. Sustainable food consumption. Exploring the consumer "attitude-behavioral intention" gap. Journal of Agricultural and Environmental Ethics, 19, 169-194.

VITERI, F.E.; GONZALEZ, H. 2002. Adverse outcomes of poor micronutrient status in childhood and adolescence. Nutrition Reviews, 60, 77-83.

WALL, R. 2012. Ovine cutaneous myiasis: effects on production and control. Veterinary Parasitology, 189, 44-51.

WATERHOUSE, A. 1996. Animal welfare and sustainability of production under extensive conditions - A European perspective. Applied Animal Behaviour Science, 49, 29-40.

WATHES, C.M.; JONES, C.D.R.; WEBSTER, A.J.F. 1983. Ventilation, air hygiene and animal health. Veterinary Record, 113, 554-559.

WHEELER, M.B.; WALTERS, E.M.; CLARK, S.G. 2003. Transgenic animals in biomedicine and agriculture: outlook for the future. Animal Reproduction Science, 79, 265-289.

WILMUT, I.; SCHNIEKE, A.E.; MCWHIR, J.; KIND, A.J.; CAMPBELL, K.H.S. 1997. Viable offspring derived from fetal and adult mammalian cells. Nature, 385, 810-813.

WINDSOR, P.A.; LOMAX, S. 2012. Addressing welfare concerns in control of ovine cutaneous myiosis in sheep in Australia. Small Ruminant Research, 110(2-3), 165-169.

WILliamS, P.; DROULEZ, V.; LEVY, G., STOBAUS, T., Y SINCLAIR, A. 2002. Composition of Australian red meat. Final Report prepared for MLA. North Sydney, New South Wales, Australia.

WOOD, J.D.; ENSER, M. 1997. Factors influencing fatty acids in meat and the role of anti-oxidants in improving meat 
quality. British Journal of Nutrition, 78, S49-S60.

WOOD, J.D.; FISHER, A.V. 1990. Improving the quality of lamb meat-taste, fatness and consumer appeal. Slade C.F.R., y Lawrence, T.L.J. (Eds.), New developments in sheep production, Occasional Publication, 14, 88-108. London: British Society of Animal Production.

WOOD, J.D.; RICHARDSON, R.I.; NUTE, G.R.; FISHER, A.V.; CAMPO, M.M.; KASAPIDOU, E.; SHEARD, P.R.; ENSER, M. 2003. Effects of fatty acids on meat quality: a review. Meat Science, 66, 21-32.

WORLD CANCER RESEARCH FUND (WCRF)! AMERICAN INSTITUTE FOR CANCER RESEARCH. 2010. Systematic literature review continuous update project report, the associations between food, nutrition, and physical activity and the risk of colorectal cancer. Available from: http:// www.dietaandcancerreport.org/ cancer_resource_center/downloads/cu/ Colorectal\%20cancer\%20CUP\%20report $\% 200 c t \% 202010$.
YOUNG, O.A.; LANE, G.A.; PRIOLO, A.; FRASER, K. 2002. Pastoral and species flavour in lambs raised on pasture, lucerne or maize. Journal of the Science of Food and Agriculture, 83, 93-104.

YOUNG O.A.; BAUMEISTER, B.M.B. 1999.The effect of diet on the flavour of cooked beef and the odour compounds in beef fat, New Zealand Journal of Agricultural Research, 42, 297-304.

ZANDER, K.; HAMM, U. 2010. Consumer preferences for additional ethical attributes of organic food. Food Quality and Preference, 21, 495-503.

ZANDER, K.; STOLZ, H.; HAMM, U. 2013. Promising ethical arguments for product differentiation in the organic food sector. A mixed methods research approach. Appetite, 62, 133-142.

ZHANG, X.Y.; HUANG, J.K.; QIU, H.G.; HUANG, Z.R. 2010. A consumer segmentation study with regards to genetically modified food in urban China. Food Policy, 35, 456-462. 


\title{
SUPLEMENTACIÓN DE LA RECRÍA Y ENGORDE DE OVINOS SOBRE CAMPO NATURAL
}

L. Piaggio ${ }^{1}$

\section{RESUMEN}

\begin{abstract}
La producción ovina en nuestro país tiene como principal base el campo natural. En la última década diversos factores han llevado a que el rubro enfrente un fuerte desafío intensificación, de mejorar la productividad, y fundamentalmente hacerlo sobre campo natural o en zonas agroecológicas más pobres. En este nuevo paradigma productivo es que se comenzó a trabajar en alternativas de suplementación sobre campo natural, focalizando los dos períodos más críticos en la producción de pasturas naturales que son el invierno y el verano. En el presente trabajo se presentan diferentes alternativas de suplementación con concentrados o con pasturas o cultivos de alto aporte proteico para mejorar la recría estival. Para el invierno se presenta la curva de respuesta en el desempeño de corderos a niveles crecientes de suplementación proteica. Adicionalmente se presenta una síntesis de un primer trabajo que se focaliza en el efecto de la alimentación durante la gestación, lactación y recría estival en el desempeño reproductivo de corderas en el primer otoño de vida. Finalmente se presenta una síntesis de diversos trabajos en el engorde de corderos sobre campo natural con concentrados durante el invierno y se discute diversos aspectos a tener en cuenta en la suplementación sobre campo natural para lograr altas eficiencias de conversión.
\end{abstract}

Palabras clave: suplementos, ovinos, recría, engorde, campo natural

\section{INTRODUCCIÓN}

La producción ovina en nuestro país tiene como principal base el campo natural. En la última década diversos factores que incluyen la competencia por área con otros rubros como agricultura, forestación y ganadería vacuna, y dentro de los sistemas ganaderos la competencia por pasturas de calidad con los vacunos, sumado a otros factores como los asociados al cambio climático, que aumentan los riesgos en la base pastoril, exigencias de mitigación de emisiones de gases de efecto invernadero, así como otros factores sociales y factores asociados a precios de los productos derivados del rubro, han llevado a que el rubro enfrente un fuerte desafío intensificación, de mejorar la productividad, y fundamentalmente hacerlo sobre campo natural o en zonas agroecológicas más pobres. En este nuevo paradigma productivo la carne ha pasado a ser un compo- nente importante de los ingresos, pesando en las decisiones productivas dentro del rubro y por lo tanto la mejora en la eficiciencia globlal del sistema pasa por la mejora de los indicadores de eficiencia de cada uno de los procesos fisiológicos, tanto reproducción, como crecimiento, como el engorde.

Es en este marco que desde comienzos de la década pasada, en el SUL se inició la generación de alternativas de suplementación sobre campo natural, focalizando los dos períodos más críticos en la producción de pasturas naturales que son el invierno y el verano. Como se puede apreciar en el Cuadro 1, la producción de materia seca del campo natural sobre cristalino tiene una fuerte variación estacional y dentro de estaciones. La producción de forraje está concentrada en la primavera, iniciando el descenso hacia el verano, con mínimos valores en el invierno. Es importante resaltar la alta variación de las tasas de crecimiento de pasturas na- 
Cuadro 1. Campo Natural de Cristalino: producción diaria de Materia Seca (kg MS/ha/día); Energía Metabolizable Estimada (Mcal EME/kg MS) y contenido de Proteína Cruda (\% BS). Valores promedio por estación (Adaptado de Formoso, 2001).

\begin{tabular}{|l|c|c|c|c|}
\hline & Verano & Otoño & Invierno & Primavera \\
\hline Tasa de Crecimiento (kg/ha/día MS) & & & & \\
Promedio & 13,0 & 9,3 & 6,7 & 17,3 \\
Máximo-Mínimo & $24-3$ & $17-5$ & $13-2$ & $24-6$ \\
Energía Metabolizable (Mcal EME/kg MS) & 2,1 & 2,2 & $2, .0$ & 2,4 \\
Proteína Cruda \% PC (BS) & 9,3 & 9,7 & 8 & 10,3 \\
\hline
\end{tabular}

turales dentro de cada estación, presentando el invierno y el verano las mayores variaciones y la mayor probabilidad de ocurrencia de los menores registros.

Considerando la calidad de las pasturas, en el mismo cuadro se puede observar indicadores de calidad como el contenido de energía metabolizable estimado y el contenido de proteína cruda. Estos valores también son variables y dependen en gran medida del manejo de la pastura, pero puede observarse que excepto en la primavera en el resto del año son valores medios a bajos los que se pueden esperar en este tipo de pasturas los cuales son adecuados para determinados procesos fisiológicos pero no para procesos exigentes como para invernada de corderos, y en muchas oportunidades no son suficientes para las ganancias de peso moderadas requeridas para una correcta recría. Aún considerando la alta selectividad de los ovinos, en asignaciones de pastura que permiten la expresión de la selectividad, Montossi et al. (2000) en verano registraron valores de 2 unidades porcentuales por encima del valor de proteína del disponible, mientras que en términos de energía la selectividad permitió obtener dietas 0,3 Mcal de energía metabolizables superiores a la pastura ofrecida. Si tomamos de referencia la guía de requerimientos nutricionales del NRC (2007) o CSIRO (2007) se puede inferir que las necesidades para una correcta recría y principalmente para crecimiento+engorde, son superiores a la calidad que en la mayoría de las situaciones pueden obtener en pastoreo de campo natural, como se ilustra en la Figura 1.

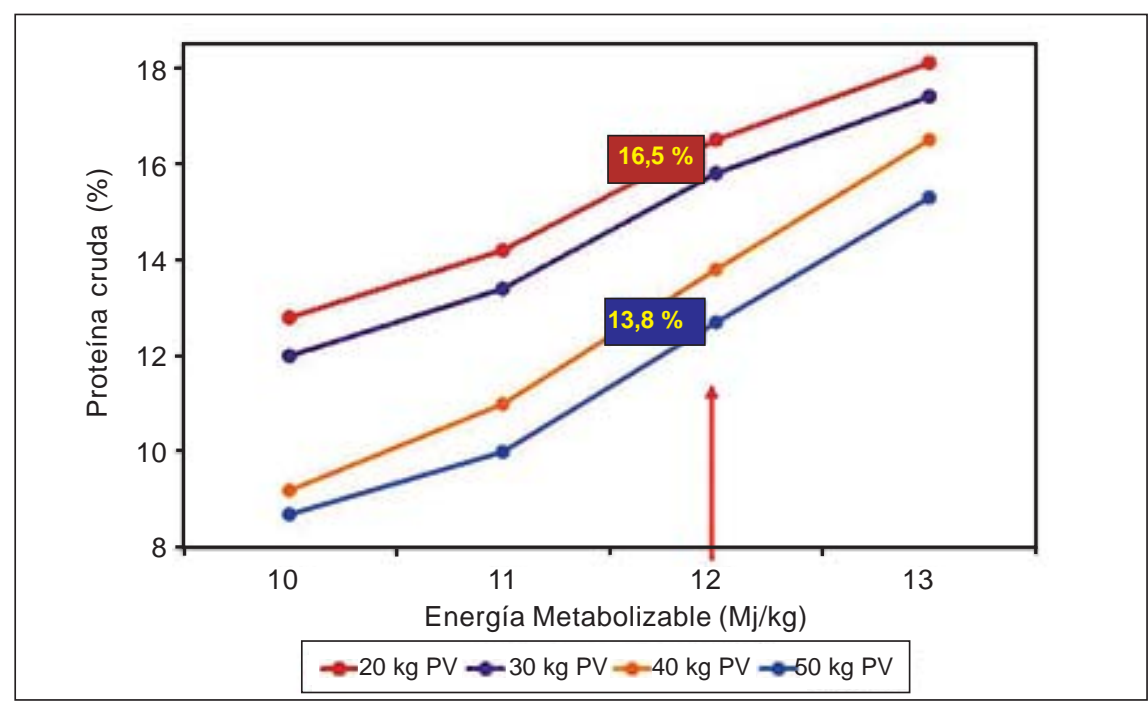

Figura 1. Guía de necesidades de energía y proteína, expresadas en concentración diaria, para diferentes fases de crecimiento y engorde de corderos (G. Duddy, 2007). 
Es en este marco que el objetivo del presente trabajo es resumir los coeficientes técnicos generados para diversas alternativas de alimentación en la recría estival de corderos y los obtenidos para el engorde de corderos con alimentos concentrados sobre campo natural.

\section{ALTERNATIVAS ALIMENTICIAS PARA MEJORAR LA RECRÍA ESTIVAL}

En la mayoría de los sistemas de producción ovina, la recría de corderos se realiza sobre campo natural y los niveles nutricionales medios a bajos que se les asigna a partir del destete se reflejan en ganancias diarias de peso vivo menores a las que debería presentar esta categoría para un buen desarrollo.

El verano es un período que presenta limitantes para aquellos corderos nacidos en primavera y destetados a los tres meses de edad. En términos generales, las pasturas naturales, por estar la mayoría de las especies que integran la comunidad nativa en etapa reproductiva, presentan baja calidad tanto en su valor energético como proteico. Ocurre lo mismo con las pasturas de especies sembradas tradicionales, habiendo pocas alternativas con alta tasa de crecimiento y alta calidad en verano (alfalfas, lotus maku, lotus san gabriel, lotus tenuis, trébol rojo). En ambos tipos de pastura la capacidad de carga estival para buen comportamiento productivo es baja, de manera que la productividad predicha es baja. Con esta oferta forrajera debemos enfrentar la primera etapa de crecimiento post-destete en que se encuentran los corderos, caracterizada por alta demanda de nutrientes (proteína y energía) y alto riesgo sanitario, acentuados por el estrés que significa el destete.

Existen diversas alternativas alimenticias para levantar estas restricciones:

$>$ Suplementación con concentrados proteicos

$>$ Suplementación con concentrados balanceados
Pastoreo controlado por tiempo de acceso diario o frecuencia de acceso en días por semana a pasturas de alta calidad y alto valor proteico (tipo banco de proteína)

$>$ Pastoreo sobre praderas tradicionales yl o con especies de creciente uso en las pasturas y alto aporte estival como llantén y achicoria

Utilización de cultivos estivales anuales como soja, moha, sorgos BMR o nabos forrajeros.

Con relación a las dos primeras alternativas, uso de alimentos concentrados, en el Cuadro 2 se presenta un resumen de las respuestas productivas de corderas destetados sobre campo natural y suplementados con diferentes concentrados. Es importante resaltar la importancia de las características que debe reunir el potrero de campo natural elegido para destetar los corderos, manejo desde la primavera para disponer de «pasturas seguras», disponibilidad de agua y sombra, etc., aspectos fundamentales pero que escapan los objetivos del presente trabajo.

Lo primero a resaltar es la enorme variación del comportamiento productivo del testigo a campo natural, con años de ganancias de peso que duplican las de los otros. En segundo lugar la diferencia del tipo de bloque proteico de los primeros experimentos, en los cuales la fuente de proteína era fundamentalmente nitrógeno no proteico (Piaggio et al., 2011a) y los bloques del último experimento, reflejo de una tecnología de producción de bloques nutricionales que ha mejorado sustancialmente (Piaggio et al., 2013c). En tercer lugar, en los años en que se experimentó con harina de soja peleteada, alimento proteico de alta calidad y alta energía, se registró respuesta importante, siendo una opción a considerar en caso de no disponer de pasturas de calidad(Piaggio et al., 2012a, Marichal et al., 2013, Piaggio et al., 2013c). Para la utilización de harina de girasol como suplemento es importante tener presente la diferencia de respuesta frente a la harina de soja, obteniéndos desem- 
Cuadro 2. Respuesta en desempeño animal a la suplementación estival con alimentos concentrados. Ganancia Diaria Media expresada en $\mathrm{g} / \mathrm{cord} / \mathrm{d}$ y relativa al campo natural del año correspondiente en porcentaje.

\begin{tabular}{|c|c|c|c|c|c|}
\hline Alternativa Alimenticia & 2004 & 2005 & 2006 & 2007 & 2012 \\
\hline Campo Natural ${ }^{1}$ (Testigo) & $\begin{array}{c}33 \\
(100)\end{array}$ & $\begin{array}{c}46 \\
(100)\end{array}$ & $\begin{array}{c}62 \\
(100)\end{array}$ & $\begin{array}{c}55 \\
(100)\end{array}$ & $\begin{array}{c}57 \\
(100)\end{array}$ \\
\hline Pradera $^{2}$ & 93 & 61 & 70 & & \\
\hline Campo Natural + Ración 16 (300 g/c/d) & 95 & 116 & 72 & & \\
\hline Campo Natural + Bloque Proteico (NNP) ${ }^{3}$ & $\begin{array}{c}34 \\
(103)\end{array}$ & $\begin{array}{c}51 \\
(111)\end{array}$ & & & \\
\hline Campo Natural + Bloque Proteico (Proteína Verdadera) & & & & & $\begin{array}{c}83 \\
(146)\end{array}$ \\
\hline Campo Natural + H. Soja $100 \mathrm{~g} / \mathrm{c} / \mathrm{d}^{4}$ & & $\begin{array}{c}71 \\
(153)\end{array}$ & $\begin{array}{c}89 \\
(144)\end{array}$ & & $\begin{array}{c}86 \\
(151)\end{array}$ \\
\hline Campo natural + H. Girasol 270 g/c/d5 & & & $\begin{array}{c}83 \\
(-134) \\
\end{array}$ & & \\
\hline Campo Natural + H. Soja $150 \mathrm{~g} / \mathrm{c} / \mathrm{d}^{4}$ & & & & $\begin{array}{c}78 \\
(142)\end{array}$ & \\
\hline
\end{tabular}

${ }^{1}$ Carga de $10 \mathrm{c} / \mathrm{ha}$, disponibilidades y crecimientos diferentes en los distintos años.

${ }^{2}$ Carga de entre $14-15 \mathrm{c} / \mathrm{ha}$, disponibilidades y crecimientos diferentes en los distintos años.

${ }^{3}$ Bloques Proteicos en 2004 alta proporción de urea, en 2005 BP 30 \% de proteína verdadera pero oferta restringida a $150 \mathrm{~g} / \mathrm{c} / \mathrm{d}$.

${ }^{4}$ Harina de Soja Peleteada (entre 42 y $46 \%$ de proteína).

${ }^{5}$ Harina de Girasol Peleteada (32\% de proteína).

peños de entre $80-90 \mathrm{~g}$ de ganancia de peso por cordero por día suplementando con 100 $\mathrm{g}$ de harina de soja o $270 \mathrm{~g}$ de harina de girasol (Piaggio et al., 2012a). Esta diferencia es debida no sólo a la diferente cantidad y calidad de proteína de ambos concentrados sino a una diferencia importante en concentración energética de ambos concentrados.

Un aspecto a señalar es que los suplementos proteicos tienen la ventaja de que se pueden suministrar una o dos veces por semana o en autoconsumo sin mayores riesgos de problemas digestivos y con menores riesgos de sustitución de forraje que los alimentos energéticos.

En la Figura 2 se presenta la respuesta a niveles crecientes de suplementación con harina de soja peleteada en dos experimentos, en dos años diferentes y evaluando diferentes niveles (Piaggio et al., 2012a, Marichal et al., 2013a). Claramente se observa que a mayores niveles de suplementación mejor es el desempeño de los corderos. Si bien es necesario mayor profundización en el análisis de estas respuestas, el gran salto en respuesta se da en el primer nivel de suplementación, de 100 o 150 g de harina de soja por cordero por día.

1 Carga de $10 \mathrm{c} / \mathrm{ha}$, disponibilidades y crecimientos diferentes en los distintos años.

2 Carga de entre 14-15 c/ha, disponibilidades y crecimientos diferentes en los distintos años.

3 Bloques Proteicos en 2004 alta proporción de urea, en 2005 BP 30 \% de proteína verdadera pero oferta restringida a $150 \mathrm{~g} / \mathrm{c} / \mathrm{d}$.

4 Harina de Soja Peleteada (entre 42 y $46 \%$ de proteína).

5 Harina de Girasol Peleteada (32\% de proteína).

La eficiencia de conversión de los suplementos concentrados proteicos evaluados en los diferentes experimentos varió entre 3,5 a $7,0 \mathrm{~kg}$ de concentrado por $\mathrm{kg}$ de ganancia de peso vivo adicional al testigo sin suplemento, siendo la harina de soja la que presentó mejores valores de eficiencia.

Con relación a otras alternativas pastoriles, su discusión escapa los objetivos del 


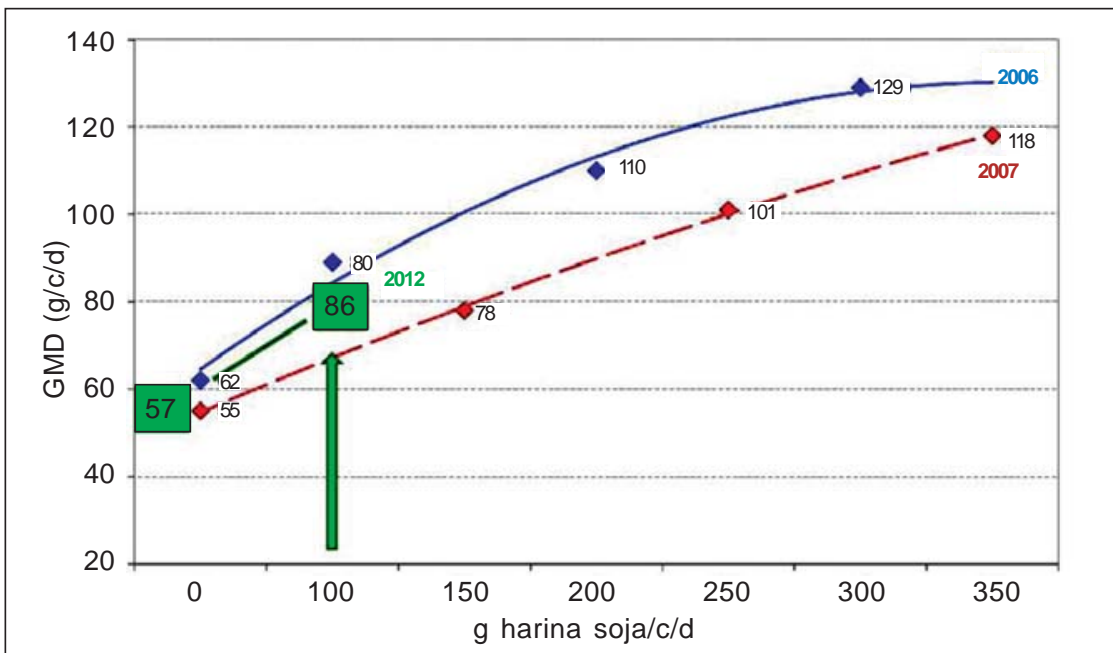

Figura 2. Respuesta a niveles crecientes de suplementación con harina de soja sobre campo natural en la recría de verano. Evaluaciones CIEDAG 2006, 2007 y valor testigo y suplementado con harina de soja $(100 \mathrm{~g} / \mathrm{c} / \mathrm{d})$ en verano 2012.

presente trabajo. De todos modos es interesante señalar la posibilidad de uso de pasturas altas en proteína, como Lotus Makú o cultivo de soja como suplemento de proteico del campo natural, utilizándolos en pastoreo controlado por tiempo o frecuencia de acceso (Piaggio y Saavedra, 2008).

En el Cuadro 3 se presenta resultados de experimentos evaluando el uso de pasturas o cultivos de alta concentración en proteína utilizados como suplementación proteica o banco de proteína y el desempeño productivo de corderos en cultivos de soja (Alonso et al., 2006) o de sorgo BMR fotosensitivo manejado a baja altura con alta carga de corderos, como alternativas alimenticias a considerar en la planificación de la recría estival (Stella et al., 2012).

Si extrapolamos valores de los vacunos, para lograr una correcta recría, deberíamos lograr una ganancia diaria de peso vivo de entre 0,2 a $0,4 \%$ del peso vivo. Esto sería equivalente a fijarnos como rangos de ganancia de peso vivo en la recría de entre 50$100 \mathrm{~g} / \mathrm{cord} / \mathrm{d}$. Para lograr estas ganancias el pastoreo controlado sobre lotus makú (Piaggio et al., 2013a), ya sea controlando el acceso en horas por día o en días por semana es una alternativa que ha dado excelentes resultados, como se observa en el Cuadro 3, prácticamente duplicando las ga- nancias de peso de los corderos testigo a campo natural.

El cultivo de soja es otra alternativa pastoril que puede utilizarse tanto como único alimento o como suplemento de proteína, con acceso de tiempo controlado en horas por día. La hoja del cultivo de soja tiene un contenido de proteína de entre $24-28 \%$, y el cordero come selectivamente la hoja, por lo cual es una alternativa que puede considerarse como suplemento proteico del campo natural, con acceso de 3 hs/día.

El cultivo de sorgo forrajero no había mostrado buenos resultados hasta estos últimos años. Pero esta especie ha sido objeto de una fuerte selección en calidad, por lo que en los últimos experimentos, de pastoreo de sorgos BMR, fotosensitivos, con corderos de destete ha mostrado ser una alternativa a considerar para manejo de altas cargas, manteniendo el sorgo a menos de $60 \mathrm{~cm}$ de altura, y presenta alta respuesta a la suplementación proteica (Cuadro 3).

El otro período que presenta importantes limitantes para la recría en cantidad y calidad de pasturas es el período invernal. Como alternativas para superar estas limitantes pueden ser consideradas la suplementación con concentrados balanceados, la suplementación con concentrados proteicos de forma similar a lo detallado para el verano, o tam- 
Cuadro 3. Respuestas a la suplementación estival mediante pastoreo controlado en especies de alto contenido de proteína y desempeño en cultivos anuales estivales (Ganancia diaria media en $\mathrm{g} / \mathrm{cord} / \mathrm{d}$ y relativa al campo natural del año correspondiente en porcentaje entre paréntesis).

\begin{tabular}{|c|c|c|c|c|c|c|}
\hline Alternativa Alimenticia & 2004 & 2005 & 2006 & 2007 & 2012 & 2013 \\
\hline Campo Natural $^{1}$ (Testigo) & $33(100)$ & $46(100)$ & & 12 & 57 & \\
\hline Campo Natural + L. Makú 1 día cada 7 días $^{2}$ & $61(185)$ & & & & & \\
\hline Campo Natural + L. Makú 1 día cada 3 días² $^{2}$ & $78(236)$ & & & & & \\
\hline Campo Natural + L. Makú 1 día cada 3 días ${ }^{2}$ & & $62(135)$ & & & & \\
\hline Campo Natural + L. Makú 3 h(s)/día ${ }^{2}$ & & 87 (189) & & & & \\
\hline $\begin{array}{l}\text { Cultivo de Soja } 6 \text { h(s)/d (40 cord/h) + Encierro c/agua } \\
\text { y sombra }\end{array}$ & & & 103 & & & \\
\hline $\begin{array}{l}\text { Cultivo de Soja pastoreo permanente ( } 25 \text { cord/ha) } \\
\text { c/agua y sombra }\end{array}$ & & & 172 & & & \\
\hline $\begin{array}{l}\text { Cultivo de Soja pastoreo permanente ( } 30 \text { cord/ha) c/agua } \\
\text { y sombra }\end{array}$ & & & & 125 & & \\
\hline $\begin{array}{l}\text { Cultivo de Soja } 3 \mathrm{~h}(\mathrm{~s}) / \mathrm{d}(70 \text { cord/ha) + Campo Natural } \\
\text { c/agua y sombra }\end{array}$ & & & & 87 & & \\
\hline $\begin{array}{l}\text { Cultivo de Sorgo BMR fotosensitivo (50 cord/ha) c/agua } \\
\text { en parcela }\end{array}$ & & & & & 73 & 56 \\
\hline $\begin{array}{l}\text { Cultivo de Sorgo BMR fotosensitivo (50 cord/ha) c/agua } \\
\text { en parcela }+200 \mathrm{~g} \text { harina de soja }\end{array}$ & & & & & 149 & \\
\hline $\begin{array}{l}\text { Cultivo de Sorgo BMR fotosensitivo (50 cord/ha) c/agua } \\
\text { en parcela }+115 \mathrm{~g} \text { harina de soja }\end{array}$ & & & & & & 104 \\
\hline $\begin{array}{l}\text { Cultivo de Sorgo BMR fotosensitivo ( } 50 \mathrm{cord} / \mathrm{ha} \text { ) c/agua } \\
\text { en parcela }+ \text { bloques proteicos } 330 \mathrm{~g} / \mathrm{c} / \mathrm{d}\end{array}$ & & & & & 133 & \\
\hline
\end{tabular}

${ }^{1}$ Carga en el Campo Natural $10 \mathrm{c} / \mathrm{ha}$.

${ }^{2}$ Carga en Lotus Makú 23 corderos/ha.

bién puede ser utilizado el pastoreo controlado por tiempo de acceso con frecuencia de horas por día o días por semana según la pastura. En esta publicación nos referiremos sólo a la suplementación proteica. En la Figura 3 se presenta la respuesta en el des-

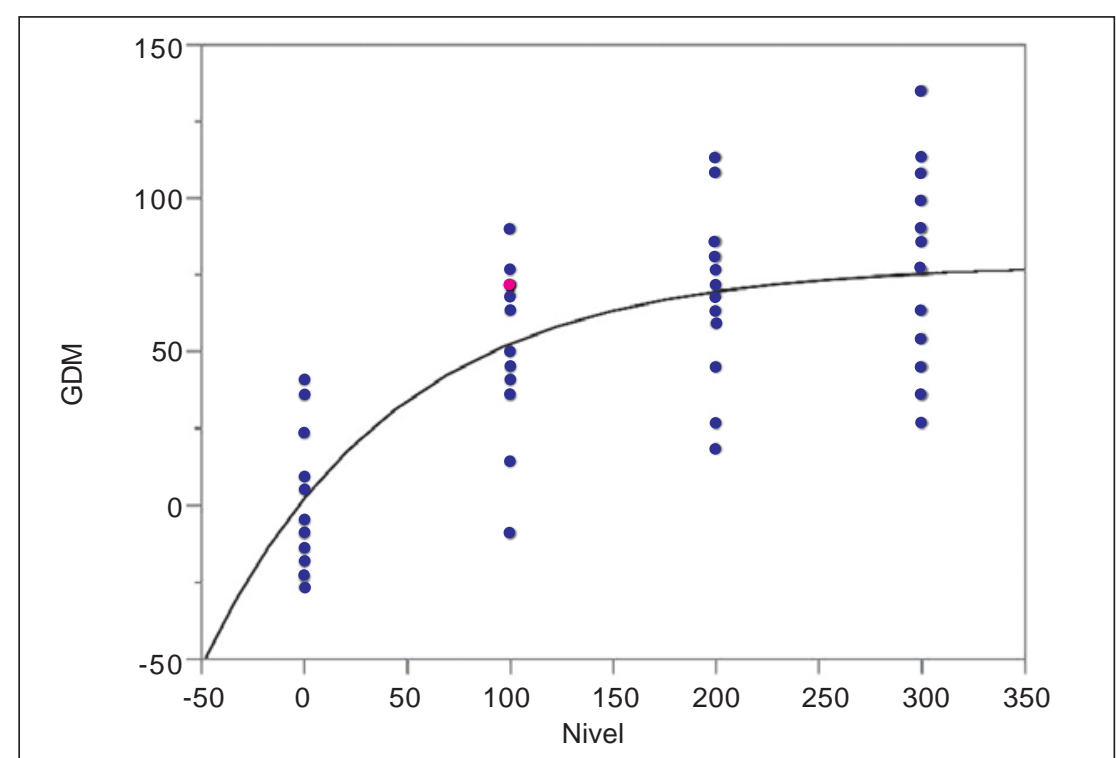

Figura 3. Desempeño de corderas suplementadas con niveles crecientes de harina de soja sobre campo natural de cristalino en invierno. (Marichal et al., 2013b). 
empeño de corderos sobre campo natural en invierno suplementados con niveles crecientes de harina de soja. Claramente el campo natural sólo apenas permite el mantenimiento del peso vivo, y la suplementación con harina de soja peleteada en una dosis de $100 \mathrm{~g} / \mathrm{c} / \mathrm{d}$ permite una ganancia de peso de casi $50 \mathrm{~g} / \mathrm{c} / \mathrm{d}$, mínimo aceptable para un animal en crecimiento, con una eficiencia de conversión de 2:1. El modelo ajustado es de cinética de primer orden, en que la respuesta es decreciente a medida que aumentamos la dosis de harina de soja, correspondiendo el valor asintótico de ganancia de peso próximo a los $80 \mathrm{~g} / \mathrm{c} / \mathrm{d}$.

En el trabajo realizado evaluando diferentes niveles de alimentación en tres fases comprendidas entre el fin de la vida fetal (último mes de gestación) y primer otoño de vida sobre el peso vivo (Piaggio et al., 2013b), claramente se visualiza el efecto que tiene un correcto nivel de nutrición en las diferen- tes fases sobre el peso vivo en el primer otoño de vida, resultando en una diferencia mayor a los $5 \mathrm{~kg} /$ cordera (Figura 4). Analizando el efecto de la fase 1 que se presenta en el Cuadro 4, fase que corresponde a la alimentación en los últimos 30 días de gestación y primeros 24 de lactancia (después de la esquila pre-parto y hasta la señalada), no se detectó diferencia $(P=0,62)$ en el peso al nacer de los corderos nacidos de madres en el campo natural o en pradera, pero sí en el peso a la señalada $(P<0,01)$ y al destete $(P<0,01)$ lo que reflejaría un efecto en la lactancia.

Realizando similar análisis para la fase 2, correspondiente a la alimentación desde la señalada hasta el destete, en que el nivel bajo de alimentación fue campo natural y el alto fue alimentación diferencial al pie de la madre (creep feeding) con harina de soja (Cuadro 5), fue evidenciada una interacción entre ambas fases de alimentación, presen-

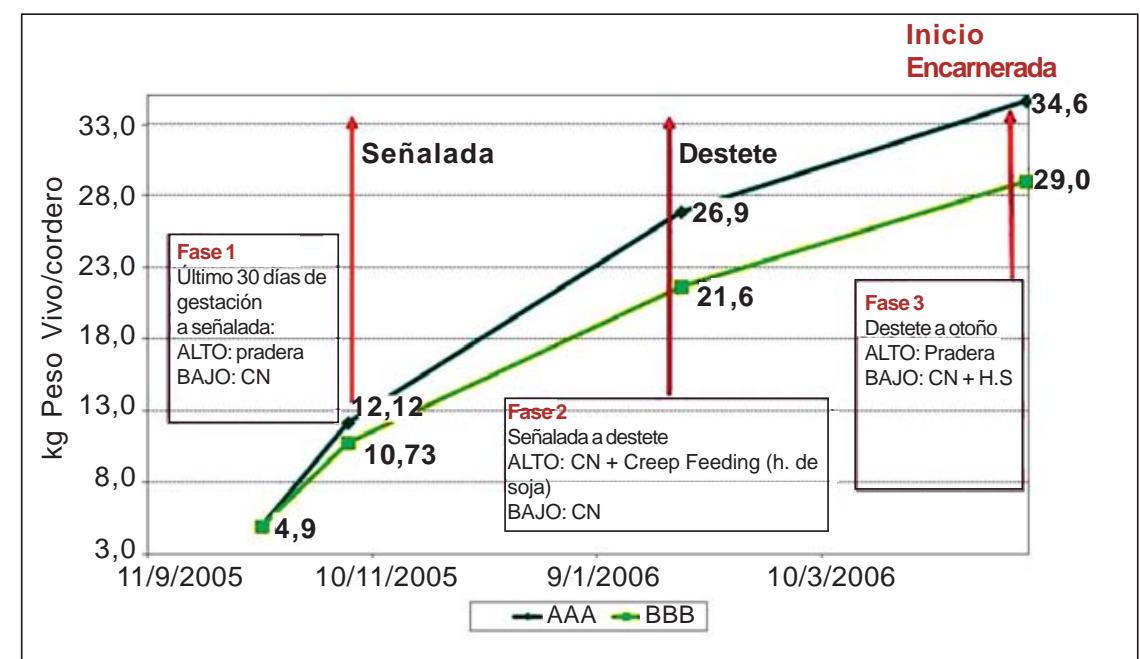

Figura 4. Efecto del nivel de alimentación en tres fases comprendidas entre el fin de la vida fetal y la encarnerada al $1^{\text {er }}$ otoño sobre el peso vivo al inicio de la encarnerada (Piaggio et al., 2013).

Cuadro 4. Efecto del nivel de alimentación desde la esquila pre-parto hasta la señalada: 54 días en total (30 días pre-parto + 24 días lactancia).

Fase 1: EFECTO EN PESO VIVO

\begin{tabular}{|c|r|r|c|}
\hline \multirow{2}{*}{ Nivel alimentación } & \multicolumn{3}{|c|}{ Peso vivo (kg/cordero) } \\
\cline { 2 - 4 } & Nacimiento & Señalada & Destete \\
\hline Bajo & 4,89 & $10,7 \mathrm{~b}$ & $23,5 \mathrm{~b}$ \\
Alto & 4,96 & $11,8 \mathrm{a}$ & $25,4 \mathrm{a}$ \\
Valor P & 0,62 & 0,003 & 0,0003 \\
\hline
\end{tabular}


Cuadro 4. Efecto de la alimentación diferencial al pie de la madre (Creep Feeding $\mathrm{CN} \mathrm{H}$. Soja) desde señalada a destete.

Fase 2: EFECTO EN GANANCIA DIARIA MEDIA DE PESO VIVO (g/c/d)

\begin{tabular}{|c|c|c|}
\hline & \multicolumn{2}{|c|}{$\begin{array}{c}\text { Fase } 1 . \\
\text { Interacción F1 F2 P=0,058 }\end{array}$} \\
\hline & Bajo & Alto \\
\hline Fase & & \\
\hline Bajo & 122 & 140 \\
\hline Alto & 160 & 160 \\
\hline
\end{tabular}

tando mayor respuesta en ganancia de peso vivo en esta fase las corderas nacidas de madres que recibieron bajo nivel de alimentación al fin de la gestación y principios de la lactancia.

En la fase 3, que va desde el destete hasta el primer otoño de vida, las corderas que pastorearon pradera llegaron con mayor peso que las que estuvieron a campo natural suplementadas $(P>0,01)$, siendo que el peso final de esta fase fue discriminativo en el suceso preñez, siendo el umbral de peso vivo para preñez en estas corderas Corriedale de casi 7 meses de edad de $35 \mathrm{~kg}$ (Piaggio et al., 2013b), registrando $47 \%$ de preñez las corderas de nivel alto de alimentación en las tres fases.

Como conclusión, existen diversas alternativas de alimentación para mejorar la recría de los corderos y corderas, necesario tanto para la recría de hembras en su primer verano para encarnerada de cordera diente de leche o para su primer y eventualmente segundo verano para garantizar la encarnerada de borrega. En el caso de los corderos, estas alternativas de recría permiten un buen desarrollo estival y por lo tanto comenzar la invernada con un tamaño relativo muy superior, un 20 a un $25 \%$ más de peso vivo inicial, permitiendo lograr las ganancias de peso diario consistente

\section{ENGORDE DE CORDEROS SOBRE CAMPO NATURAL CON ALIMENTOS CONCENTRADOS}

Una alternativa de alimentación que a partir del 2006 está siendo evaluada y validada con resultados promisorios es el engorde intensivo con concentrados sobre campo natural en invierno. Esta estrategia de alimentación surgió como alternativa para zonas de bajos índices de productividad agroecológicos, como una alternativa de menor competencia con los bovinos por los escasos recursos forrajeros de calidad y como herramienta que permitiera viabilizar una oferta contínua y planificada de carne ovina de calidad. Como ya se discutió, el campo natural en invierno presenta bajas a nulas tasas de crecimiento y baja calidad, de manera que el rol del alimento concentrado en esta alternativa es aporte de todos los nutrientes (energía, proteína, minerales), utilizando el pastoreo sobre campo natural como fuente de fibra. Desde 2006 a la fecha han sido realizados experimentos evaluando cantidades crecientes de concentrado, tipo de concentrado utilizando diferentes granos y diferentes concentrados proteicos, carga de corderos por unidad de superficie, uso de aditivos y biotipos de corderos (Piaggio, 2009, 2010). 
Con relación a las cantidades de concentrado diario a suministrar, a partir de $500 \mathrm{~g}$ de concentrado por cordero por día, los incrementos de ganancia diaria de peso vivo fueron francamente decrecientes, resultando entonces la cantidad recomendada a utilizar en torno a los $500 \mathrm{~g} / \mathrm{c} / \mathrm{d}$, equivalente al $1,5 \%$ del peso vivo (variando entre 1,3 a 2,0 \%) con índices de conversión del orden de 4 a 1 . El concentrado utilizado en las primeras experiencias fue en base a grano de maíz y harina de soja peleteada, siendo el valor de proteína del concentrado que resultó en mayores ganancias de peso vivo de próximo a 18,5 \% de PC base seca (Piaggio et al. 2009). En cuanto al alimento energético utilizado los resultados mostraron que el grano de maíz podía ser sustituido por grano sorgo, o grano de sorgo en mezcla con afrechillo de arroz, o el pelet de cáscara de soja, con similares resultados (Marichal et al., 2011). Los granos de cereales se usaron enteros, tanto el sorgo como el maíz, y en el caso del sorgo, el silo húmedo de grano fue utilizado en validaciones con la misma eficiencia que la prevista a partir del grano entero. Con relación al concentrado proteico no es tan clara la sustitución de la harina de soja, ya que este alimento aporta alta proteína de calidad y alta energía, lo cual no es fácil de sustituir. Sin embargo no fueron detectadas diferencias en la fuente de $\mathrm{N}$ utilizada pero sí en las cargas de corderos sobre el campo natural (Piaggio et al., 2012b). Con relación a los minerales, en todos los casos se corrigió el concentrado para aportar calcio y fósforo en relación próxima a 2 a1. Con relación al uso de aditivos que mejoren la eficiencia no ha sido clara la respuesta (Piaggio et al., 2011b). El cumplimiento de la rutina y el respeto de las recomendaciones de espacios por animal, piso firme, etc. han mostrado ser aspectos clave en el resultado obtenido. Con relación a la carga, los experimentos han sido conducidos con 10 a 15 corderos/ha, siendo que los mejores resultados se obtuvieron con cargas que permitan un $6 \%$ de oferta de pastura, lo que es más común obtenerlo con cargas de 10 corderos/ha y en algunos años de crisis forrajeras con cargas menores. Un aspecto importante a tener en cuenta en la implementación de esta alternativa de ali- mentación es la necesidad de suministro de agua de calidad y a voluntad, como en todas las situaciones en que se suministra alimentos concentrados.

En síntesis de los diversos trabajos realizados evaluando carga de corderos a utilizar, fuente energética, fuente proteica, cantidad de concentrado, nivel de proteína, los resultados indican que suministrando una cantidad de concentrado en torno al 1,5 a 2,0 \% del peso vivo, de alta energía metabolizable (>2,8 Mcal/ kg MS) y concentración de 16 a $18 \%$ de proteína verdadera, con una relación de calcio a fósforo de 2 a 1 , la ganancia de peso vivo obtenida es del orden de 0,4 a $0,5 \%$ del peso vivo promedio del período de engorde. Para una oferta de pastura en el rango de 4 a $6 \%$ de material verde seco y un suministro de concentrado de 0,5 a $2,0 \%$ del peso vivo la eficiencia de conversión esperada está en el rango de 3,5 a 4,0 $\mathrm{kg}$ de concentrado por $\mathrm{kg}$ de peso vivo ganado.

En conclusión, el engorde de corderos sobre campo natural suplementado con alimento concentrado balanceado ha mostrado ser una alternativa para producción de Cordero Pesado que viabiliza la producción de carne ovina de calidad en zonas agroecológicas más pobres, disminuyendo la competencia por pasturas de calidad con los bovinos y permitiendo una oferta planificada del producto.

\section{BIBLIOGRAFÍA}

ALONSO, O.; AQUINO,G.; PONTTI,G.; PIAGGIO, L.; NORBIS, H. 2006. Evaluación del cultivo de soja como forrajera estival para producción de cordero precoz pesado.Lananoticias144: 26-33.

CSIRO. 2007. Nutrient Requirements of Domesticated Ruminants. 270 p.

FORMOSO, D.; OFICIALDEGYI, R.; NORBIS, H. 2001. Producción y valor nutritivo del campo natural y mejoramientos extensivos. Secretariado Uruguayo de la Lana. Utilización y manejo de mejoramientos extensivos con ovinos. Montevideo. pp. 7-11.

MARICHAL, M DE J; PIAGGIO, L.; DEL PINO, M.L.; DESCHENAUX, H. 2011. Alternativas de suplementación de corderos pastoreando 
campo natural. XXII Reunión de la Asociación Latinoamericana de Producción Animal, Montevideo.

MARICHAL, M DE J.; DEL PINO, L.; DESCHENAUX, H.; PIAGGIO, L. 2013a. Post-weaning growth of lambs grazing natural pastures supplemented with protein concentrates. Book of Abstracts No.19 of the 64th meeting of the European Federation of Animal Science. Nantes, France, 26-30 August, 2013. 19, 374.

MARICHAL, M. DE J,.; PIAGGIO, L.; DEL PINO, L.; DESCHENAUX, H. 2013b. Levels of soybean meal supplementation of lambs grazing native pastures in the winter season. En prensa, enviado a International Symposium on the Nutrition of the Herbivorous (ISNH-ISRP 2014), en revisión.

MONTOSSI, F.; PIGURINA, G.; SANTAMARINA, I.; BERRETA, E. 2000. Selectividad animal y valor nutritivo de la dieta de ovinos y vacunos en sistemas ganaderos: teoría y práctica. Montevideo, INIA. 84 p. Serie Técnica no. 113.

NATIONAL RESEARCH COUNCIL. 2007. Nutrient requeriments of small ruminants. Sheep, goats, cervids, and new world camelids. Washington, D.C., National Academies Press. $362 \mathrm{p}$

PIAGGIO, L.; SAAVEDRA, R. 2008. Alternativas alimenticias para la producción de corderos pesados. Carne Ovina de calidad Cordero pesado. Secretariado Uruguayo de la Lana, Publicación Ocasional p.: 31-61,

PIAGGIO, L. 2009. Suplementación con concentrados para el engorde de corderos sobre campo natural. In: Anuario de la Sociedad de Criadores de Corriedale 2009, p. 72-77.

PIAGGIO, L.; OFICIALDEGUI, R.; GUELVENZU, L.; DEGES, M. 2009. Engorde de corderos sobre campo natural suplementados con concentrados. Memorias AALPA, Vol XVII, Sup. 1, 208-213.

PIAGGIO, L. 2010. Suplementación y Engorde a Corral. Resultados, Desafíos. Necesidades de Investigación. III Congreso de la Asociación Uruguaya de Producción Animal , Montevideo , 2010. Agrociencia. Número Especial, 77-81.

PIAGGIO, L.; PASTORÍN, A.; MARICHAL, M DE J. 2011a. Effect of protein supplementation of lambs grazing natural pastures. Advances in Animal Biosciences. Proceedings of the 8 th International Symposium on the Nutrition of the Herbivorous (ISNH8), 2, 282.

PIAGGIO, L.; DEL PINO, M.L.; MARICHAL, M DE J. 2011b. Effect of lasalocid supplementation on performance of lambs grazing natural pastures. Advances in Animal Biosciences. Proceedings of the 8th International Symposicum of the Nutrition of Herbivorous, 2, 481.

PIAGGIO, L.; DEL PINO, L.; DESCHENAUX, H.; MARICHAL, M DE J. 2012a Soybean meal supplementation of lambs grazing native pastures in the summer-fall season. Joint Annual Meeting ADSA AMPA ASAS CSAS, Tucson, Arizona, 2012.

PIAGGIO, L.; DEL PINO, L.; DESCHENAUX, H.; OFICIALDGUI, R.; MARICHAL, M DE J; BENTANCUR, O. 2012 b. Engorde de corderos sobre campo natural suplementados con concentrados: efecto de la carga animal y de la fuente de proteína del concentrado. IV Congreso Asociación Uruguaya de Producción Animal 29-30 de Octubre de 2012, Montevideo.

PIAGGIO, L.; MARICHAL, M DE J.; PASTORÍN, A. 2013a. A «protein bank» of Lotus uliginosus cv. Maku as an alternative to conventional protein supplements for weaned lambs grazing on natural pastures during summer and autumn. Animal Production Science, 2013. (Manuscrito AN13324.R1revisado y aceptado para publicación).

PIAGGIO, L.; DESCHENAUX, H.; REY, F.; FIERRO, S.; QUINTANS, G.; BANCHERO, G. 2013b. Effect of nutrition level between fetal life to onset of breeding period of Corriedale ewelambs: weight at service and reproductive outcomes. Animal Production Science. Manuscrito AN13260, en revisión.

PIAGGIO, L; BARBOSA, M.; MACHADO, D.; DESCHENAUX, H.; DEL PINO, L.; MARICHAL, M.J. 2013 c. Suplementación Proteica en la Recría Estival. Lananoticias $\mathrm{n}^{\circ}$ 164: 6-8 pp.

STELLA, L.; PIAGGIO, L.; DEL PINO, L.; DESCHENAUX, H. 2012. Sorgo forrajero BMR como forrajera estival para pastoreo de corderos. Lananoticias, v: 162 , p: 1215, 2012. 
MANEJO SANITARIO DURANTE LA CRÍA

Y RECRÍA DE CORDEROS

A. Mederos Silveira ${ }^{1}$

\section{RESUMEN}

A pesar de que en nuestro país existen varios problemas que afectan a la salud de los ovinos fundamentalmente en las categorías jóvenes, existen alternativas para la prevención y control de la mayoría de ellos.

En Uruguay, gracias a la acción combinada y complementaria de las instituciones públicas (Ministerio de Ganadería, Agricultura y Pesca, Universidad de la República) y privadas (Secretariado Uruguayo de la Lana, Plan Agropecuario e Instituto Nacional de Investigación Agropecuaria), gremiales y sociedad de productores, han podido generar, validar y transferir tecnologías con resultados sumamente auspiciosos.

Sin embargo, todavía existen desafíos y necesidades de investigación para resolver problemas complejos como es el caso de las miasis y resistencia a las drogas fundamentalmente por parte de parásitos gastrointestinales, entre otras. También es de fundamental importancia el rol de la extensión y transferencia de tecnología para promover el uso racional y responsable de las drogas para evitar no solo el desarrollo de resistencia de los agentes, sino también para prevenir daños en el ambiente y residuos en los alimentos.

Palabras clave: sanidad, ovinos, cría, recría

\section{INTRODUCCIÓN}

Los sistemas de producción ovina de nuestro país se encuentran libres de muchas de las enfermedades de la Lista de la Oficina Internacional de Epizootias en vigor en 2013 y no están presente en ovinos, importantes enfermedades, como son Scrapie y Maedi-Visna (OIE, 2013).

Esto en parte se debe a las acciones conjuntas realizadas tanto por instituciones públicas, privadas, con la plena participación de técnicos y productores agropecuarios

No obstante ello, existen problemas que afectan a la salud de los ovinos del Uruguay y estos pueden agruparse en forma general por su etiología en aquellos de origen infeccioso o parasitario.

Las enfermedades de origen infeccioso más comunes que se presentan durante las etapas de cría y recría son las clostridiosis, ectima contagioso, queratoconjuntivis y afecciones podales (principalmente el footrot ovino).

El objetivo del presente trabajo es presentar un resumen de los principales problemas sanitarios a tener en cuenta durante la cría y recría ovina y algunas de las acciones que se deben realizar para prevenir y/o controlar los efectos de las mismas.

\section{PROBLEMAS DE ORIGEN INFECCIOSO}

\section{Enfermedades clostridiales}

Las enfermedades clostridiales son producidas por bacterias del genero Clostridium las que normalmente son habitantes del suelo $y$ el tracto gastrointestinal de los animales y se encuentran en todas partes del mundo.

Las clostridiosis más comunes en el Uruguay, se pueden clasificar en: 
a) Mionecróticas sépticas: Mancha, ocasionada por el Clostridium chauvoei y Gangrenas gaseosas originadas por los Clostridium septicum, Clostridium oedematiens, Clostridium welchii y Clostridium histolyticum.

b) Infecciosas: Hepatitis necrótica infecciosa (Clostridium oedematiens tipo B) y Enterotoxemia (Clostridium welchii tipo D).

c) Intoxicaciones neurotrópicas: Tétano (Clostridium tetani).

La clostridiosis más común en nuestros sistemas de producción es la enterotoxemia (Clostridium welchii tipo D), también denominada enfermedad del riñón pulposo o de la abundancia. Dicha enfermedad se manifiesta en animales en muy buen estado fisiológico, con dietas abundantes y ricas en proteína y energía (Casas, 1974).

\section{Control y prevención}

La prevención de las clostridiosis se realiza en base al uso de vacunas polivalentes que contienen los diferentes clostridios presentes en el medio, inactivadas en formol y de administración por vía subcutánea. Lo recomendable es vacunar a las ovejas de cría antes del parto para que el cordero adquiera una buena inmunidad calostral. En caso de que esto no se haya realizado, lo recomendable es realizar la primera vacunación en el momento de la señalada. En animales primo vacunados se deben realizar dos aplicaciones, con intervalo de 30-45 días de acuerdo al fabricante, aprovechando el efecto Booster y generando así una buena inmunidad de base. La inmunidad se instala a partir de los 15 días post vacunación y se debe reforzar cada seis meses o al año, dependiendo del tipo de vacuna utilizada y de la situación epidemiológica de cada establecimiento. Como todo producto biológico, se debe de aplicar correctamente, en animales de buen estado general, no estresados y sin otras patologías, a fin de conferir una buena inmunidad (Bonino y col., 1987). Se debe tener presente que la protección no es del $100 \%$ de los animales.

También se debe incluir en este plan de vacunaciones, una vacuna contra Carbunco bacteridiano que es una importante zoonosis causada por el Bacillus anthrasis.

\section{Ectima contagioso}

El Ectima contagioso (dermatitis pustular contagiosa o boquera) es una enfermedad contagiosa de la piel causado por un virus del género Parapoxvirus. Esta enfermedad es más común en ovinos y en caprinos, aunque puede afectar en forma poco frecuente a otros rumiantes, animales salvajes y también al hombre, siendo considerada una zoonosis menor. Las lesiones primarias se desarrollan en la piel de los labios extendiéndose a la mucosa de la boca. En algunos casos se pueden encontrar lesiones en las patas en el espacio interdigital y en la zona de la corona (Bonino, 1988)

\section{Control y prevención}

Esta enfermedad se previene eficazmente mediante vacunación. Esta es una vacuna viva, altamente eficaz y se aplica mediante escarificación en la parte interna de la pierna y se realiza una sola vez en la vida del ovino.

\section{Queratoconjuntivitis}

La queratoconjuntivitis ovina es una enfermedad infecciosa de distribución mundial. El agente etiológico es Neisseria ovis aunque existen controversias dado que esta bacteria es habitante usual de la conjuntiva ocular y necesitaría de la invasión de otros agentes, como por ejemplo Mycoplasma conjunctivae, para multiplicarse y producir lesiones en la córnea. En nuestro país es una enfermedad de distribución esporádica $y$ frecuentemente aparece en primavera-verano coincidiendo con la temporada de moscas de la miasis.

\section{Control y prevención}

El tratamiento curativo se hace en forma local con colirios líquidos o en polvo (antibiótico y antisépticos), pudiéndose utilizarse en forma de aerosol, con la precaución de hacerlo a distancia $(15-25 \mathrm{~cm})$, para evitar lesiones en cornea. La enfermedad es 
muy contagiosa, en la presencia de un brote se aconseja separar animales enfermos de sanos, realizar los tratamientos antes mencionados y proteger de la luz solar.

El uso de vacunas en forma preventiva, no es de utilización muy frecuente por ser su acción poco eficaz (Bonino, 1980, Bonino y col., 1987).

\section{Afecciones podales}

En el Uruguay existen problemas podales de diferente etiología, los cuales son: Footrot (Pietín); Absceso de dedo; Absceso de pie; Dermatitis interdigital; Separación de muralla; Ectima contagioso; Manquera posbalneación y Strawberry Footrot.

Encuestas de opinión y posteriores relevamientos nacionales, demostraron que la principal afección podal es el Footrot o Pietín (enfermedad infecto-contagiosa), causada por una asociación bacteriana del Fusobacterium necrophorus y el Dichelobacter nodosus, siendo este último el responsable de la transmisión. Los factores predisponentes más comunes para la transmisión, son la humedad, calor y lesiones del pie (Egerton y Roberts, 1971).

Los últimos estudios de investigación realizados en el país han apuntado al conocimiento de la prevalencia a nivel del país y pérdidas productivas y económicas ocasionadas por esta enfermedad.

Un relevamiento nacional realizado en otoño de 1999 , mostró que el $69,7 \%$ de los predios con ovinos presentaron problemas de footrot y que el 6,7\% de los animales estaban afectados. La prevalencia de la enfermedad en carneros fue de 19,8\%; en ovejas de cría de 7,4\% y en borregos/as de 3,9\% (Bonino y col., 2000).

Las pérdidas productivas causadas por el footrot, evaluadas en experimentos realizados durante los años 1998-2000 en borregos Corriedale (sin considerar las complicaciones secundarias más comunes de miasis), fueron de un $4 \%$ en peso vivo. Dichas diferencias alcanzaron hasta un $9,7 \%$ en épocas de alta prevalencia de footrot. No hubo diferencias estadísticamente significativas en los parámetros de producción de lana, salvo en rendimiento al lavado y resistencia de la fibra (Mederos y col., 2001).

El período del año más favorable para la transmisión de la enfermedad en los dos años de estudio, fue el otoño. Basado en las estimaciones de pérdidas productivas y prevalencia, se cuantificó el efecto económico mediante un modelo valorando un rebaño de 2000 capones con tasas de prevalencia estimada de 30, 20, 10 y 6,7\%. Las estimaciones mostraron que el footrot puede producir descensos de hasta un $25 \%$ en el margen bruto con prevalencias de la enfermedad de un $10 \%$. Los beneficios que se pueden esperar al realizar un control adecuado de la enfermedad que considere todo el predio, son altamente favorables (Ferreira y col., 2002).

\section{Prevención y control de enfermedades podales}

Los programas de control/erradicación de pietín existentes en el país, están basados en la eliminación de portadores crónicos y tratamiento de los enfermos.

Los tratamientos de esta enfermedad son principalmente tópicos basados en el uso de pediluvios con diferentes antisépticos y parenterales mediante uso de antibióticos.

El programa consta de las siguientes etapas: diagnóstico, control, erradicación y vigilancia.

El diagnóstico consiste en examen clínico de las pezuñas de la totalidad de los ovinos por personal capacitado y basados en la escala descrita por Egerton y Roberts (1971) los animales se dividen en tres categorías: sanos, tratables y/o recuperables (grados de 1 a 3) y crónicos incurables (Figura 1). La época recomendada para esta actividad es cuando la transmisión de la enfermedad es baja (período seco), requiriéndose instalaciones adecuadas.

Los animales sanos pasan por un pediluvio preventivo y van a un potrero libre de ovinos durante 14 días.

El control de los animales enfermos, se realiza mediante correcto despezuñado y tratamientos en pediluvios de sulfato de zinc al 10\% (antiséptico de elección) durante 15 minutos, siendo fundamental que los anima- 

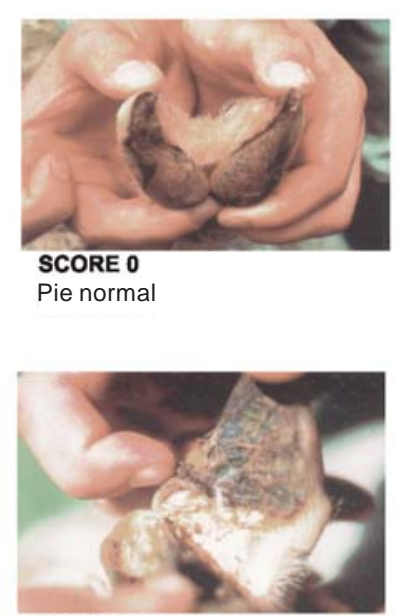

SCORE 3

Separación de las uniones de piel con la pezuña que se extiende a la parte interna de talones

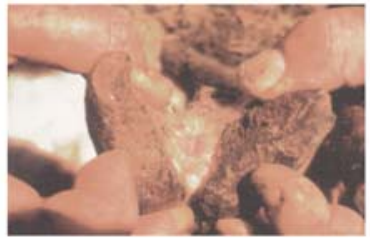

SCORE 1

Inflamación moderada de la piel del espacio interdigital

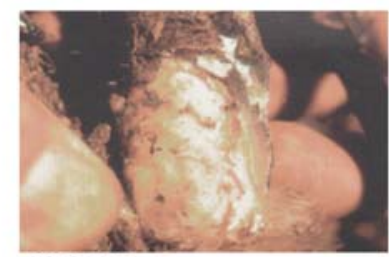

SCORE 4

Separación de los tejidos blandos y duros de la pezuña, que se extiende al borde interno de la misma

Figura 1. Footrot ovino, definición de los signos clínicos.

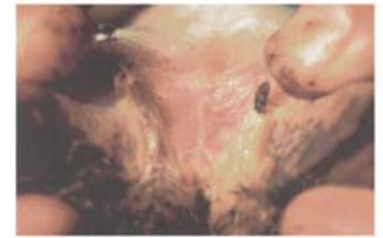

SCORE 2

Inflamación necrótica de la piel del espacio interdigital que se extiende a los tejidos blandos de la pezuña

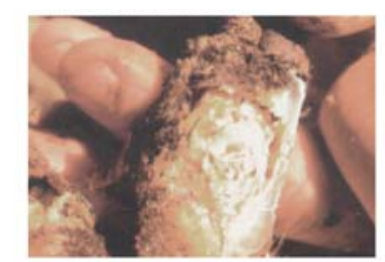

SCORE 5

Inflamación necrótica de las capas profundas de la epidermis, que se extiende a todos los tejidos duros de la misma

Fuente: SUL-INIA, escala basada en Egerton y col., 1971.

les permanezcan en un ambiente seco luego del tratamiento. Este tratamiento deberá ser realizado 3 veces con intervalos de 7 días. Luego de finalizado el mismo, se vuelve a realizar examen clínico de las pezuñas de todos los animales, incorporándose los recuperados al lote sano y los no curados al grupo de crónicos para su eliminación (Bonino, 2001).

En algunos casos (pocos animales a tratar o animales de valor) el tratamiento de pediluvios puede complementarse mediante la administración parenteral de antibióticos a base de Penicilina (70000Ul/kg de peso vivo) y estreptomicina $(70 \mathrm{mg} / \mathrm{kg}$ de peso vivo), u Oxitetraciclinas de Larga Acción (20 mg/kg de peso vivo) entre otros (Egerton y Roberts, 1971).

El grupo de animales crónicos incurables, debe ser eliminado del predio, siendo su destino la faena.

\section{PROBLEMAS DE ORIGEN PARASITARIO}

\section{Parasitosis internas}

Las parasitosis internas, fundamentalmente los parásitos gastrointestinales (PGI), son una de las principales causas de pérdi- das productivas y económicas en las categorías jóvenes de ovinos que son las más susceptibles. Por otro lado, esto se ha agravado en los últimos años debido a la aparición de resistencia a las drogas antihelmínticas.

Las principales especies de PGI de importancia económica que han sido identificadas en nuestro país son el Haemonchus contortus, Trichostrongylus axei, Ostertagia circumcinta en el abomaso y Trichostrongylus colubriformis, Nematodirus spp., Cooperia spp., Oesophagostomum spp., Trichuris spp. en intestinos.

\section{Control y prevención}

En Uruguay así como en el resto del mundo, el control de las parasitosis gastrointestinales se ha realizado fundamentalmente basado en el uso de drogas antihelmínticas, lo cual llevó al desarrollo de cepas parasitarias resistentes. Un relevamiento realizado en nuestro país por SUL-DILAVE (Nari et al., 1996), mostró que el 92,5\% de los predios con producción ovina tenían algún grado de resistencia antihelmíntica. Analizado por grupo químico, el $86 \%$ de los predios presentó resistencia a los Bencimidazoles, $71 \%$ a los levamisoles y 1,2\% a las ivermectinas. En esta oportunidad el principal nematodo involucrado en la resistencia fue el Trichostrongylus spp. 
El relevamiento de resistencia antihelmíntica de 1994 no ha sido actualizado, pero el análisis de información restrospectiva de laboratorios que se encuentran trabajando en este tema (SUL, INIA y Lorenzelli-Macchi), han revelado que en los últimos años se ha ido intensificando el número de predios con desarrollo de resistencia a las Ivermectinas, principalmente por parte de Haemonchus spp. (Castells y col., 2002, Mederos y col., 2005).

Debido al desarrollo de resistencia antihelmíntica descripto arriba, los métodos de control han tenido que ser revisados y en la actualidad los trabajos de investigación y difusión están dirigidos al estudio de métodos integrados de control parasitarios que combinen el uso de métodos químicos y no químicos.

El Control racional integrado de parásitos (CRIP) se define como la combinación y utilización adecuada de los métodos de control parasitarios disponibles, con la finalidad de mantener niveles aceptables de producción sin la eliminación del agente causal (Nari y Eddi, 2002).

En términos de resistencia a los antiparasitarios, el CRIP intenta retardar el aumento de aquellas poblaciones parasitarias con mayor proporción de individuos genéticamente resistentes a uno o más antiparasitarios. Dichos métodos se basan fundamentalmente en: uso de químicos en forma racional y aplicación de métodos alternativos como ser manejo del pastoreo, selección y uso de animales genéticamente resistentes, manejo de la nutrición, uso de forrajes bioactivos, controles biológicos y vacunas.

A pesar de la presencia de resistencia antihelmíntica, el uso de químicos continúa siendo una herramienta esencial. Existen tres grupos de antihelmínticos de amplio espectro: Bencimidazoles (Albendazol, Fenbendazol y otros); levamisoles (Levamisol y Morantel) y lactonas macrocíclicas (Ivermectina, Doramectina, Moxidectin); un grupo fosforado de espectro medio (Naftalophos) y dos grupos de espectro reducido, salicilanidas y fenoles sustituidos (Closantel, Rafoxanide y Nitroxinil) y fosforados de espectro reducido (Triclorfón). A partir del año 2010, contamos en Uruguay con una molécula nueva de amplio espectro, monepantel (Zolvix).

El uso de dichas moléculas químicas en Ios CRIP, se basa en primer lugar en el diagnóstico de la eficacia de la misma en cada predio, Test de Reducciòn del Conteo de Huevos (Lombritest) y el uso de las mismas en forma racional. En muchos casos, los niveles de resistencia antihelmíntica, obligan a la utilización de combinaciones de estos productos de forma de lograr alta eficacia y amplio espectro simultáneo.

Si bien la aplicación de dosificaciones tácticas y estratégicas se han ido modificando, estas últimas se mantienen y en el caso de la majada se realizan en la pre-encarnerada, preparto, señalada y destete. En el momento actual, cada establecimiento deberá elegir la droga a utilizar basándose en los resultados del Lombritest.

Por otro lado, nuevas estrategias que apuntan a una disminución en el uso de antihelmínticos en la totalidad de la majada, es la dosificación individual solo a los animales afectados. Este método es aplicado en algunos lugares como en Nueva Zelanda (Drench on Demand), Australia (Dosificaciones por cambio de peso) y en Sudáfrica (Famacha), con diferentes criterios de evaluación dependientes fundamentalmente del nematodo considerado (escore de diarrea para Trichostrongylus colubriformis y coloración de la mucosa ocular para Haemonchus contortus).

En Uruguay, existen numerosos trabajos de investigación sobre métodos alternativos para ser incluidos en programas CRIP (Nari y Eddi, 2002, Mederos y Banchero, 2013.)

\section{Parasitosis externas}

Las parasitosis externas que afectan a nuestras majadas son el piojo (Damalinia ovis y Linognathus pedalis) y la sarna ovina (Psoroptes ovis y Chorioptes ovis). Estas enfermedades son de denuncia obligatoria ante el Ministerio de Ganadería Agricultura y Pesca (MGAP), quién instrumenta en forma conjunta con el sector privado las campañas sanitarias para el control/erradicación de las mismas y la vigilancia epidemiológica co- 
rrespondiente. Otra parasitosis externa de gran consideración, es la miasis (bichera) producida por Cochliomyia hominivorax, mosca típica de estas latitudes.

\section{Control y prevención}

\section{Piojos}

Los tratamientos previstos son en base a organosfosforados, piretroides y mezclas, siendo muy rigorosos en su aplicación a fin de evitar problemas de resistencia y fundamentalmente agresiones a los operarios, medio ambiente o generar residuos a nivel de lana y carne.

Los métodos sugeridos son el baño de inmersión, que es el más eficiente, siempre y cuando se realice correctamente y nunca más allá de 180 días previos a la esquila, pera evitar problemas de residuos en la lana. El uso de pour on es otra herramienta eficaz, debiendo utilizarse inmediatamente después de la esquila y antes de que los animales tengan seis semanas post esquila, aplicándose desde la nuca hasta la cola en la línea media dorsal, con una dosis determinada por los animales de mayor peso.

Dichas acciones deben ser coordinadas con los predios vecinos, tratándose la totalidad de animales existentes.

Estas recomendaciones se basan en: a) la esquila elimina una gran cantidad de piojos con la lana, b) los rayos solares actúan como piojicidas, c) el tratamiento sin lana favorece el contacto y dispersión del producto por la piel y d) se precisa menor volumen del producto, lo que repercute en menores costos, menor posibilidad de generar resistencias, residuos, agresiones a operarios y medio ambiente (Bonino y col., 1987).

\section{Sarna}

Al igual que el piojo ovino, son de notificación obligatoria y su control-erradicación está bajo las mismas acciones sanitarias. En caso de aparición de un foco, el tratamiento se realiza en coordinación con los predios linderos, determinando el área focal y perifocal, donde se interdictan y tratan la totalidad de los animales. El método de elección para el tratamiento es el baño de inmersión con productos organofosforados, piretroides o amidinas dependiendo de la eficacia de cada uno de ellos en la zona.

Si la época del año y la cantidad de lana impiden la aplicación del baño de inmersión, otra medida es la aplicación sistémica de drogas endéctocidas como son las lactonas macrocíclicas. Una sola dosis de Doramectina (300 $\mu \mathrm{g} /$ por kg de peso vivo vía intramuscular) es efectiva, mientras que la Ivermectina inyectable $(200 \mu \mathrm{g} / \mathrm{kg}$ de peso vivo vía subcutánea) necesita dos aplicaciones con intervalos de 7 días y el Moxidectin $(200 \mu \mathrm{g} / \mathrm{kg}$ vía subcutánea) también dos tratamientos con intervalo de 10 días (Bates, 1999).

\section{Miasis}

La miasis en el Uruguay es causada por la Cochliomyia hominivorax y es un problema sanitario muy importante en nuestro medio. Las principales causas predisponentes son las afecciones podales, heridas (producidas por la esquila, castración, descole y otras), queratoconjuntivitis y ectima entre otras.

Las medidas de control de esta enfermedad se basan en acciones preventivas y curativas. La prevención está focalizada en evitar las causas predisponentes mencionadas, teniendo especial cuidado en la desinfección de cortes y en el tratamiento de las heridas.

Los tratamientos de las miasis se basan en la aplicación local de insecticidas combinados con antisépticos y cicatrizantes. La administración de Doramectina $(200 \mu \mathrm{g} / \mathrm{kg}$ de peso vivo intramuscular), a los 2 días evidenció un 100 \% de curación en trabajos experimentales, así como también ayudó a prevenir nuevas infestaciones durante períodos cortos (Castells y col., 1997 y 1999).

Aquellos países que lograron su erradicación, utilizaron métodos basados en que las hembras de esta mosca tienen la particularidad de copular una sola vez en su vida, por lo cual aplicaron medidas basados en el uso de machos esterilizados con rayos gama (Carballo, 1987). 


\section{BILIOGRAFÍA}

BATES, P. 1999. A Practical Guide to the Control of Sheep Scab. The Moredun Foundation. News Sheet Vol.3, N.3.pp 1-15.

BONINO, J. 1980. Queratoconjuntivitis ovina . Lana noticias 50 pp 11-12..

BONINO, J. DURÁN DEL CAMPO, A., MARI, J.J. 1987. Enfermedades de los Lanares. Tomos I, II y III. Ed. Hemisferio Sur. Montevideo.Uruguay $818 \mathrm{p}$.

BONINO, J. 1988. Ectima contagioso. Actualidades Agropecuarias.

BONINO, J., CASARETTO, A., MEDEROS, A., FERREIRA, G., GIL, A. 2000. Relevamiento epidemiológico de la prevalencia de footrot en ovinos del Uruguay. Producción Ovina (13) 9-25.

BONINO, J. 2001. Certificación de Planteles con programa de control de Pietin SUL. Anuario. Soc. Criadores de Corriedale, pp 92-93.

CARBALLO, M. 1987. Dípteros parásitos Enfermedades causadas por parásitos externos. Enfermedades de los lanares. Bonino Morlán J. et al. Editorial. Hemisferio Sur. Montevideo, Uruguay. Tomo I pp 242-247.

CASAS, R. 1974. Principales clostridiosis y brucelosis genital ovina. Universidad de la Republica. Fac. de Veterinaria. Bolsa del Libro. pp 37-46.

CASTELLS D.; BURLA, J.P.; BONINO, J.; MARI,J.J.; MOLTEDO, H.; ARANO, E. 1997. Efecto preventivo de la Doramectina contra Cochliomya hominivorax en ovinos. Producción ovina (10), pp19-27.

CASTELLS, D.; BURLA, J.P.; BONINO, J.; MARI J.J. 1999. Evaluación de la persistencia de la Doramectina contra larvas de Cochliomyia hominnivorax en ovinos. Producción ovina (12), pp 9-17.

CASTELLS, D. 2002. Resistencia genética del ovino a los nematodos gastrointestinales
(Revisión). Resistencia genética del ovino y su aplicación en sistemas de control integrado de parasitos. FAO, Technical publications. pp 79-86.

EGERTON, J.R.; ROBERTS D.S. 1971. J. Comp. Path. Pp 179-185.

FERREIRA, G.; MEDEROS, A.; BONINO, J.; CASARETTO, A. 2002. Estimación de costo/beneficio en el control de Footrot en Ovinos. Serie FPTA- INIA 07. pp 33-41.

MEDEROS, A.; CASARETTO, A.; FERREIRA, G.; BONINO, J.; SCREMINI, P. 2001. Evaluación de pérdidas productivas debidas a Footrot en ovinos. Serie FPTAINIA 07, pp 23-31.

MEDEROS, A.; GALLINAL, M.; GONZÁLEZ, H.; SILVA, L.; RODRIGUEZ, S. 2005. Diagnóstico de resistencia a los antihelmínticos en ovinos en Uruguay. Resumen del $12^{\circ}$ Simposio Internacional de la Asociación Mundial de Laboratorios de Diagnóstico Veterinario (WAVLD), Montevideo, Uruguay.

MEDEROS, A.; BANCHERO, G. 2013. Uso de forrajes bioactivos y taninos condensados para el control de nematodos gastrointestinales de ovinos en condiciones de pastoreo en Uruguay. En prensa.

NARI, A.; SALLES, J.; GIL, A.; WALLER, P.J.; HANSEN, J.W. 1996. The prevalence of anthelmintic resistance in nematode parasites of sheep in southern Latin America: Uruguay. Vet. Parasitol. 62, 213-222.

NARI, A.; EDDI, C. 2002. Control Integrado de los Parásitos. Resistencia genética del ovino y su aplicación en sistemas de control integrado de parásitos. FAO, Technical publications. pp 79-86.

ORGANIZACIÓN MUNDIAL DE SANIDAD ANIMAL. Enfermedades, infecciones e infestaciones de la lista de la OIE en vigor en 2013. Accesible desde http:// www.oie.int/es/sanidad-animal-en-elmundo/enfermedades-de-la-lista-de-laoie-2013/. Ultima visita 7 octubre 2013. 



\section{UTILIZACIÓN DE Plantago lanceolata EN LA ALIMENTACIÓN DE CORDEROS EN EL PERÍODO ESTIVAL}

E. Barrios ${ }^{1}$

W. Ayala $^{2}$

\section{RESUMEN}

Plantago lanceolata es una especie escasamente utilizada en Uruguay, que presenta adecuada adaptación en ambientes poco fértiles, siendo tolerante a condiciones de sequía. Su valor nutritivo le confiere algunas particularidades que permiten obtener performances animales destacadas. Es así que se reportan ganancias de peso de corderos entre 0,158 y 0,226 kg/an/día durante el verano. Esto es posible si se realizan manejos de defoliación apropiados que potencien su potencial productivo en el período. En tal sentido, puede ser considerada una pastura de tipo especializado para atender las demandas de categorías en crecimiento o terminación de corderos.

Palabras clave: Llantén, corderos, utilización

\section{INTRODUCCIÓN}

Plantago lanceolata (comúnmente conocido como llantén) es una hierba perenne, apreciada por su productividad en el período estival, su valor forrajero por la presencia de compuestos secundarios, alto contenido de minerales y posibles propiedades antihelmínticas (Stewart, 1996), a pesar de que en algunas situaciones de pasturas y/o semilleros pueda ser considerada una maleza.

Es por ello que a nivel de la región este de Uruguay, se presentan una serie de oportunidades además de las mencionadas, tales como adaptación a condiciones de baja fertilidad, tolerancia a sequías y su patrón de producción estival que han promovido su evaluación como alternativa en la alimentación de corderos.

\section{ORIGEN Y DISTRIBUCIÓN}

Originalmente proveniente de Europa, norte y centro de Asia, se encuentra ampliamente distribuido en regiones templadas. EI género Plantago comprende cerca de 270 especies y dentro del mismo Plantago lanceolata es el más relevante del punto de vista forrajero. Es altamente variable en función del hábitat que ocupa, encontrándose plantas con hojas desde pilosas a glabras, de forma alargada hasta ovoide y plantas desde postradas a erectas, en función del manejo a que se encuentre sometido (Protabase record, 2012).

\section{CARACTERÍSTICAS AGRONÓMICAS}

Se le considera como una especie de rápido establecimiento adaptándose a un amplio rango de suelos, con tolerancia a condiciones de sequía así como a diferentes plagas y enfermedades (Stewart, 1996), aún cuando el mismo puede verse limitado por la competencia de otras especies (Hildebrandt y Schultz, 1987; Sagar, 1962; Tiley y France, 1990).

Se adapta a un amplio rango de acidez $(\mathrm{pH} 4,2-7,8)$, suelos de variada textura y fertilidad (Troelstra y Brouwer, 1992), en particular en referencia a nutrientes como fósforo y potasio, aunque responde a aplicaciones de nitrógeno, promoviendo un aumento del

\footnotetext{
${ }^{1}$ Téc. en Sistemas Intensivos de Producción Animal, Programa Nacional Pasturas y Forrajes, INIA.

${ }^{2}$ Ing. Agr. PhD., Programa Nacional Pasturas y Forrajes, INIA. Director Regional INIA Treinta y Tres.
} 
número de hojas, el crecimiento general de la planta y la totalidad de biomasa, con un efecto más limitado sobre el crecimiento radicular (Lambers et al., 1981; Freijsen y Otten, 1987).

\section{PRODUCCIÓN DE FORRAJE}

Un buen número de estudios han comparado la productividad anual y estacional de Plantago con otras especies. Los resultados muestran que con determinadas condiciones, llantén puede llegar a producir 20 t/ha MS por año, alcanzando la producción de muchas otras forrajeras usadas comúnmente (Milton, 1933, citado por Fraser y Rowarth, 1996; Suckling, 1960). La evaluación de cultivares de INASE en Uruguay, no mostró diferencias en productividad entre los materiales evaluados (Tonic y Tonic plus), con producciones en el rango de 7,5 y 12,1 t/ha MS en un primer y segundo año respectivamente (INASE, 2004). Comparativamente, su producción estival supera la de Achicoria, condición que se revierte en otoño-invierno. Dentro de los cultivares disponibles, «Lancelot» presenta dormancia en el invierno, mientras que «Tonic» se mantiene activo.

\section{MANEJO DE DEFOLIACIÓN}

Las estrategias de manejo del pastoreo de llantén han sido escasamente reportadas, aún cuando se enfatiza su baja persistencia. Algunos trabajos realizados por Ayala y col. (2011), focalizaron sobre los efectos de la intensidad y frecuencia de defoliación así como el manejo invernal en la productividad y persistencia de esta especie. Existe una tendencia general hacia una reducción de la población a través del tiempo, y el pastoreo durante el invierno tiene un efecto crítico acelerando este proceso. Asimismo, la producción de forraje de llantén se incrementó 2,4 veces cuando la pastura no había sido pastoreada en invierno.

La producción de forraje de llantén no fue afectada mayormente por la intensidad ni por la frecuencia de defoliación en primavera, en cambio la defoliación frecuente (cada 21 días vs. cada 42 días) mejoró la contribución durante el verano. Características de la planta como el tamaño de la corona y el desarrollo de su sistema radicular sugieren la existencia de condiciones limitadas para las reservas de carbohidratos por parte de la planta restringiendo la productividad y persistencia bajo pastoreo intenso o condiciones limitantes de fertilidad y disponibilidad de agua, entre otros.

En base a los resultados de Kuiper y Boss (1992), llantén puede ser considerado una especie perenne de vida corta (2-3 años), siendo posible pensar en la resiembra natural como un mecanismo para mantener la población.

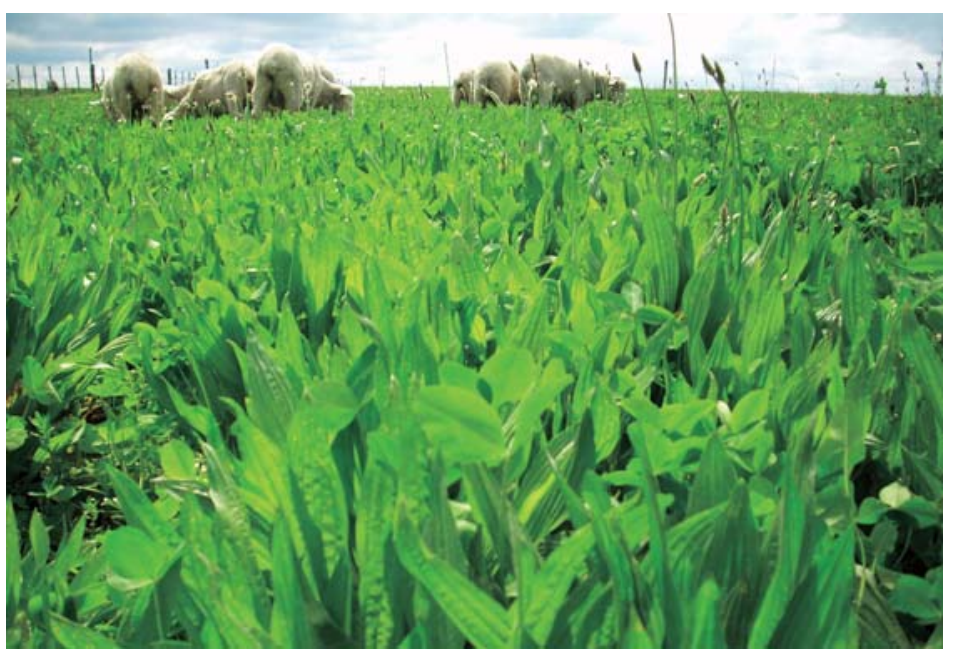

Figura 1. Pastura de llantén sembrada en forma pura en suelos de lomadas del este. 
Figura 2. La defoliación intensa afecta parámetros como el número de tallos/ planta o por unidad de superficie, el diámetro de las coronas o el tamaño de los tallos.

\section{PALATABILIDAD}

En mezclas, Plantago resulta altamente palatable para el ganado, tanto bovino como ovino, siendo más seleccionado que gramíneas y leguminosas (Milton, 1933, 1943, citado por Fraser y Rowarth, 1990; Ivins, 1952; citado por Moorhead et al., 2002; Sagar y Harper, 1964), Ilegando a resultar sobrepastoreado en comparación con otras especies (Derrick et al., 1993, citado por Sanderson et al., 2002). Rumball et al. (1997), determinaron que llantén resulta altamente apetitoso para el ganado. En ese trabajo se reporta que al inicio del período experimental se contaba con una disponibilidad inicial de 1,4 t/ha MS de trébol blanco y 1,34 t/ha MS de llantén, siendo al finalizar la evaluación de 0,15 y 0,36 t/ha MS, respectivamente; reflejando que la palatabilidad de Plantago resulta similar a la del trébol blanco. Los tallos y las plantas maduras, resultan mucho menos apetecibles que las hojas frescas (Ivins, 1952, citado por Moorhead et al., 2002). El incremento en la concentración de algunos metabolitos secundarios en plantas maduras resulta un mecanismo de defensa química frente a los herbívoros (Quintero y Bowers, 2011).

\section{COMPOSICIÓN MINERAL}

Plantago lanceolata, al igual que Cichorium intybus (achicoria), es un forraje rico en minerales, principalmente calcio, magnesio, sodio, fósforo, zinc y cobalto (Stewart, 1996). Algunos informes han comparado la composición mineral de Plantago con las gramíneas más usadas comúnmente o con tréboles. Éstos muestran que el contenido de calcio, magnesio, sodio, fósforo, zinc y cobalto de Plantago alcanza los niveles detectados en raigrás perenne y trébol rojo (Spatz y Baumgartner, 1990; citados por Stewart, 1996). La retención de calcio, magnesio y sodio de animales en pastoreo, fue más alta en aquellos que lo hacían sobre Plantago que los que lo hacían sobre raigrás perenne, llegando a ser cuatro veces mayor en el caso del calcio (Derrick, 1993). Esto sugiere que una pequeña proporción de Plantago en la mezcla de pastura, puede significar el aumento de la retención de calcio por parte de los animales (Stewart, 1996). El contenido de sodio y cobalto se ha detectado como más alto que en trébol blanco y raigrás, mientras que el contenido de calcio y zinc es similar al trébol blanco pero mayor que en raigrás. Asimismo, resulta un forraje escasamente inferior en los contenidos de potasio y magnesio (Rumball et al., 1997). 
En un ensayo realizado por Sanderson et al. (2002), comparando el valor nutritivo de varias especies forrajeras, se determinó que la inclusión de Plantago en las pasturas puede llegar a aumentar el perfil de nutrientes consumido por los animales.

\section{VALOR NUTRITIVO}

Plantago lanceolata, presenta una proporción similar de pared celular, de celulosa y de fibra detergente ácida (FDA) que el raigrás perenne, pero menos proteína cruda (PC), lignina y carbohidratos solubles que este. Los tallos de llantén tienen más celulosa, lignina y PC que el raigrás (Derrick., 1993; Wilman y Riley, 1993; Deaker et al., 1994, citados por Sanderson et al., 2002).

En experimentos realizados usando fluidos ruminales de animales que habían pastoreado varias especies, se determinó que Plantago hace descender la acción de la flora microbiana del rumen, sin perjudicar las funciones ruminales. Este efecto se atribuye a la presencia de componentes biológicos activos en la pastura (Stewart, 1996). En el ámbito internacional han sido realizados ensayos para comparar el valor nutritivo de llantén y achicoria. Particularmente, un ensayo realizado por Sanderson et al. (2002), durante el período estival, muestra que la achicoria tiene alrededor de un $11 \%$ más de digestibilidad in vitro que el llantén en cualquiera de sus cultivares. En cuanto a la proporción de Fibra Detergente Neutra (FDN), las concentraciones en achicoria resultan entre 6-20\% menores que en Ilantén. El Ilantén posee menor proporción de PC que la achicoria, reportándose niveles similares a los publicados por Volesky (1996), citado por Sanderson et al. (2002) para Cichorium intybus cv. Puna.

En otro caso, datos reportados por Fraser y Rowarth (1996), colocan a Plantago al mismo nivel de digestibilidad que achicoria, trébol blanco y raigrás. En el mismo ensayo, Plantago, es comparado con otras forrajeras en cuanto al contenido de PC, hemicelulosa, celulosa y lignina, concluyéndose que la achicoria es más digestible que el llantén, en este caso apenas un $5 \%$, resultando am- bas forrajeras con mayor digestibilidad que trébol blanco, raigrás y lotus. El tallo del llantén tiene muy baja digestibilidad y contenido de PC (Fraser y Rowarth, 1996). Las concentraciones de $\mathrm{PC}$ para corderos en crecimiento, de entre 20-30 kg PV recomendadas por NRC, son de 167-191 g/an/día, por lo que estimando un consumo promedio del $3 \%$ del PV de los animales, el llantén estaría cubriendo óptimamente dichos requerimientos.

\section{PODER ANTIHELMÍNTICO}

Los componentes antimicrobianos presentes en Plantago lanceolata son capaces de interactuar en el proceso de fermentación ruminal de los animales (Stewart, 1996). Se han reportado efectos antihelmínticos (Grieve, 1931; citado por Rumball et al., 1997), aunque otras investigaciones no han arrojado resultados positivos a tales efectos (Robertson et al., 1995). Según un ensayo publicado por Knight et al. (1996), donde se evaluó el efecto de la pastura sobre los parásitos gastrointestinales durante 1993-1995, se determinó que Plantago lanceolata, reportado como reductor de la población parasitaria en corderos (Grieve, 1931; citado por Rumball et al., 1997), no contribuyó a la reducción de dicha población. Por su parte, existe evidencia que indica el entorpecimiento de la motilidad y vitalidad de Trichostrongylus colubriformis (Pelito rojo, en estado de larva 3: L3) en corderos que han estado pastoreando Plantago lanceolata cv. Lancelot (Lane y Jenkins s/p, citados por Rumball et al., 1997).

\section{RESULTADOS DE PRODUCCIÓN DE CARNE}

Considerando a llantén como una pastura especializada, con un potencial forrajero importante a evaluar en verano, se condujo un experimento a los efectos de estimar la capacidad de carga que puede sostener una pastura de este tipo y la respuesta animal (Barrios, 2006). Entre diciembre y marzo (97 días) se evaluó una pastura pura de llantén del cv. Ceres Tonic en su primer verano. Se 
contrastaron 4 cargas animales $(10,5,13,2$, 15,8 y $18,4 \mathrm{an} / \mathrm{ha}$ ) utilizando corderos Corriedale con un peso promedio de 21,5 \pm $0,9 \mathrm{~kg}$.

El manejo de la pastura previo al inicio del ensayo permitió la acumulación a diciembre de 2,4 t/ha MS, con un 56\% de llantén. Considerando todo el verano, el régimen pluviométrico determinó que las lluvias estuvieron un $25 \%$ por debajo de la serie histórica, permitiendo aún en estas condiciones tasas de crecimiento promedio de la pastura en el período de $44,6 \pm 3,3 \mathrm{~kg} / \mathrm{ha}$ /día MS. Al igual que lo encontrado en otros experimentos, la mayor acumulación de forraje coincidió con el tratamiento de menor carga (10,5 an/ha) y determinó tasas de crecimiento $11 \%$ por debajo del promedio, posiblemente como consecuencia de una menor utilización que determina una menor tasa de renovación del forraje disponible. La pastura se manejó en pastoreo alterno de 2 parcelas con cambios cada 14 días, siendo el forraje remanente para el promedio de los tratamientos a lo largo de los 4 ciclos de pastoreo realizados de 2,0, 1,7, 1,6 y 1,6 t/ha MS respectivamente. La evolución de peso fue positiva hasta el día 84 (Figura 3), donde se manifestó la incidencia de parásitos gastrointestinales lo cual requirió una dosifi- cación general, retomando luego ganancias positivas hasta la finalización del experimento, alcanzando en promedio un peso vivo de $40,3 \mathrm{~kg} / \mathrm{an}$.

Las tasas de ganancia diaria fueron de 226 , 188, 190 y 158 g/an/día para 10,5, 13,2, 15,8 y 18,4 an/ha respectivamente. Se determinó una asociación lineal y negativa entre la ganancia diaria y el aumento de carga $(p<0,01)$, disminuyendo la ganancia 20,2 g/an por cada animal adicional por sobre 10,5 an/ha (Figura 4). Estos desempeños individuales determinaron producciones de peso vivo de 231, 240, 291 y 282 kg/ha para las cargas de 10,5, $13,2,15,8$ y 18,4 an/ha respectivamente. Asimismo, en las tres dotaciones más bajas se logró terminar el 100\% de los animales (tomando en cuenta los criterios manejados para el cordero pesado: $34 \mathrm{~kg}$ PV esquilado y 3,5 de condición corporal), mientras que se logró el $71 \%$ para la carga de 18,4 an/ha. La carga que mejor combinó performance individual, productividad por hectárea y terminación fue la de 15,8 an/ha.

Posteriormente, esta pastura se evaluó en el período invernal con cargas que variaron entre 7,5 y 15,0 an/ha, permitiendo ganancias individuales entre 185 y $133 \mathrm{~g} /$ an/día.

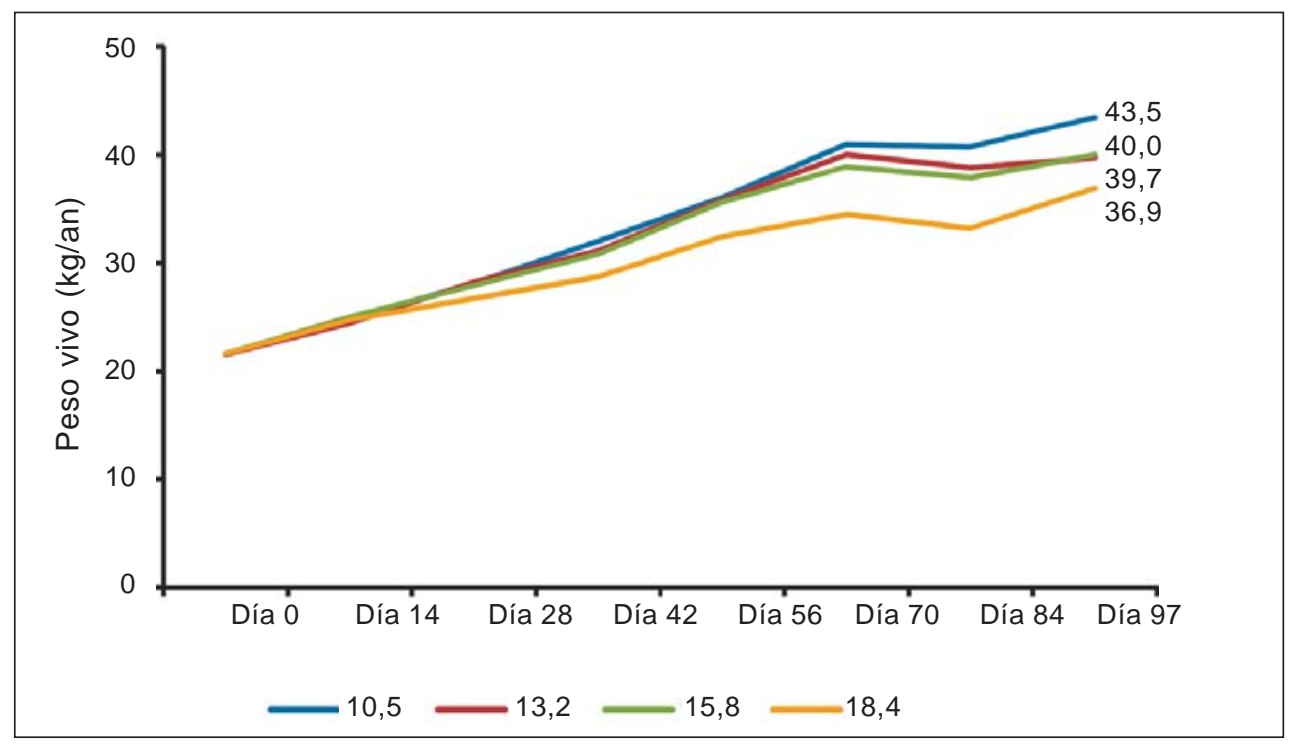

Figura 3. Evolución de Peso vivo (PV) de corderos pastoreando Plantago lanceolata en cuatro diferentes cargas $(10,5,13,2,15,8$ y 18,4 an/ha) durante 97 días entre diciembre y marzo (Barrios, 2006). 


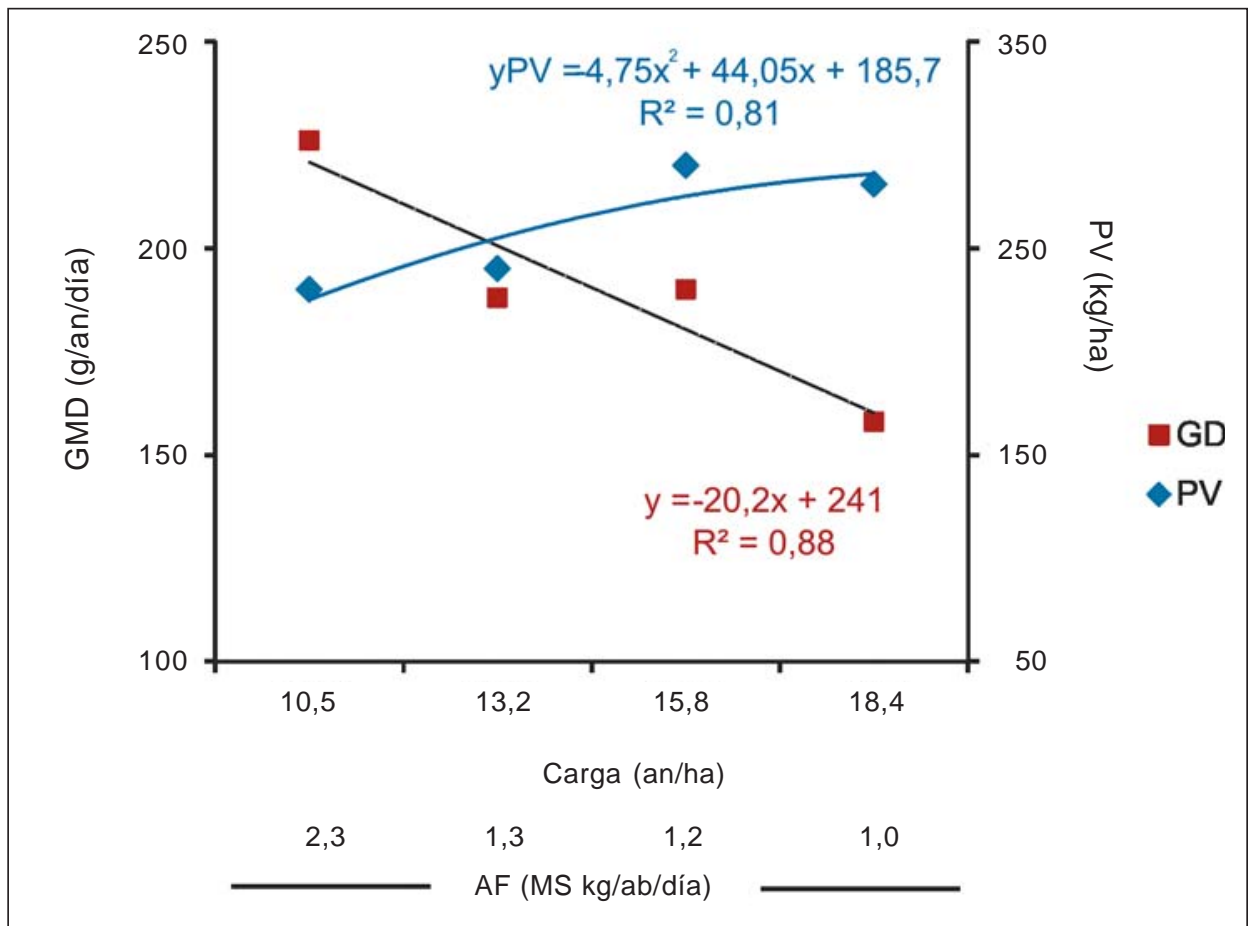

Figura 4. Asignación de forraje (AF), ganancia media diaria (GMD) y productividad por hectárea (PV/ha) de corderos Corriedale pastoreando Plantago lanceolata de primer año, durante 97 días entre diciembre y marzo (Barrios, 2006).

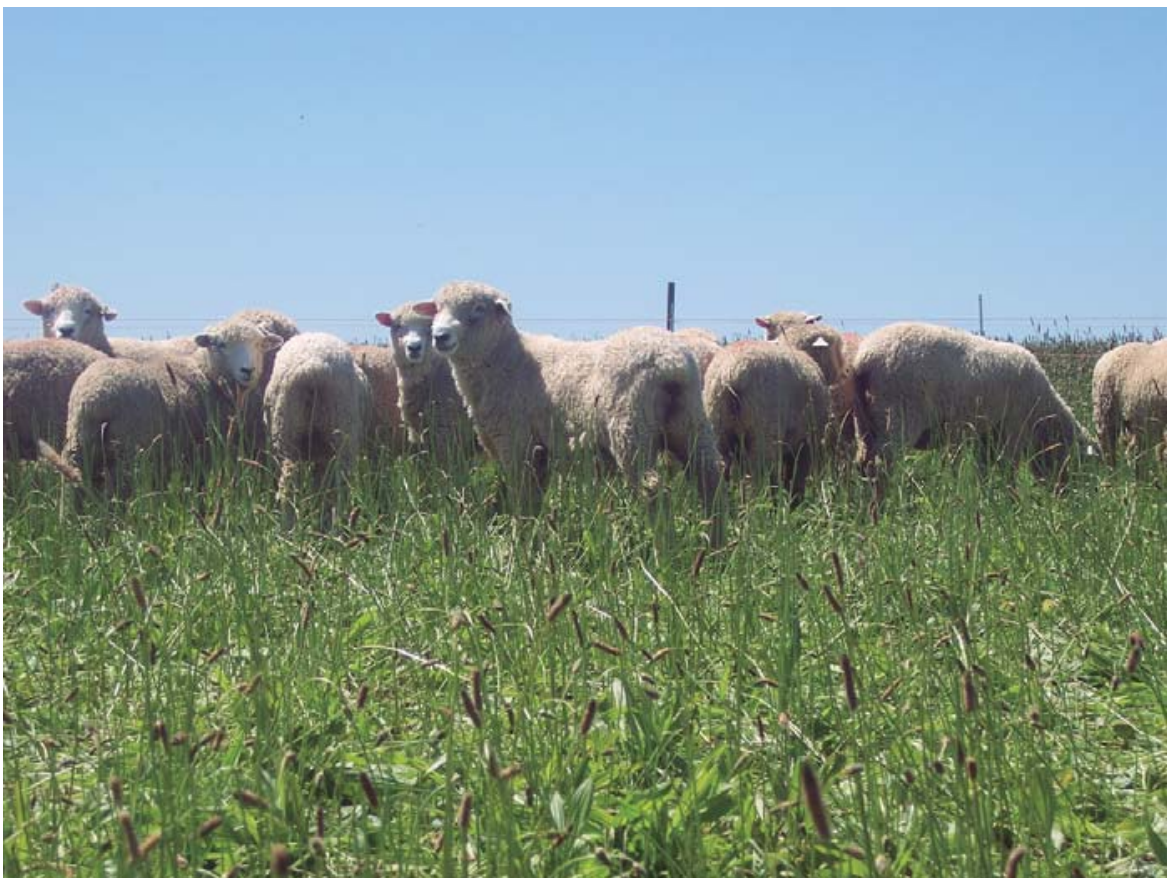

Figura 5. Lote de corderos Corriedale próximos a la finalización del período de engorde. 


\section{CONCLUSIONES}

Plantago lanceolata presenta un adecuado grado de adaptación a las condiciones de la región este, tolerando los déficit hídricos que se producen durante el verano y manteniendo buenas producciones de forraje. Si bien puede ser utilizado a lo largo de todo el año, resalta su aporte en el verano si es manejado como una pastura de tipo especializado. En ese contexto y pensando en el producto cordero precoz pesado, permitiría manejando cargas moderadas alcanzar destacadas performances individuales y altos niveles de terminación de los animales, determinando así una buena productividad del sistema.

\section{BIBLIOGRAFÍA}

AYALA, W.; BARRIOS, E.; BERMÚDEZ, R.; SERRÓN, N. 2011. Effect of defoliation strategies on the productivity, population and morphology of plantain (Plantago lanceolata L.). Pasture persistence symposium. Grassland Research and Practice Series 15: 69-72.

BARRIOS, E. 2006. Efecto de la carga animal en el comportamiento productivo de corderos pastoreando Plantago lanceolata. Trabajo de pasantía, Escuela Agraria «La Carolina», Flores, Uruguay, $73 \mathrm{p}$.

DERRICK, R.W.; MOSELEY, G.; WILMAN, D. 1993. Intake, by sheep, and digestibility of chickweed, dandelion, dock, ribwort and spurrey, compared with perennial ryegrass. The Journal of Agricultural Science 120(01): 51-61.

FAGAN, T.W.; WATKINS, H.T. 1932. The chemical composition of the miscellaneous herbs of pastures. The Welsh Agriculture Journal 6: 144-151.

FORBES, J.C.; GELMAN, A.L. 1981. Copper and other minerals in herbage species and varieties on copper deficient soils. Grass and Forage Science 36: 25-30.

FRASER, T.J.; ROWARTH, J.S. 1996. Legumes, herbs or grass for lamb performance? Proceedings of the New Zealand Grassland Association 58: 49-52.
FREIJSEN, A.H.J.; OTTEN, H. 1987. A comparison of the responses of two Plantago species to nitrate availability in culture experiments with exponential nutrient addition. Oecología 74: 389-395.

HILDEBRANDT, K.; SCHULZ, H. 1987. Sowing trials of some selected herbaceous plants. Zeitschrift fur Vegetationstechnik im Landschafts und Sportstattenbau 10: 106-110.

INASE. 2004. Instituto Nacional de Semillas Resultados experimentales de evaluación de especies forrajeras para el registro nacional de cultivares. Período 2003. p 20.

KNIGHT, T.L.; FRASER, T.L.; ROWARTH, J.S. 1996. Species effect on internal parasites. Proceedings of the New Zealand Grassland Association 58: 23-24.

KUIPER, P.J.C.; BOS, M. 1992. Plantago: A multidisciplinary study. Ecological Studies 89: Springer-Verlag, Berlin. 368 p.

LAMBERS, H.; POSTHUMUS, F.; STULEN, I.; LANTING, L.; VAN DIJK, S.; HOFSTRA, R. 1981. Energy metabolism of Plantago lanceolata as dependent on the supply of mineral nutrients. Physiologia plantarum 51: 85-92.

MOORHEAD, A.J.E.; JUDSON, H.G.; STEWART, A.V. 2002. Liveweight gain of lambs grazing «Ceres Tonic» plantain (Plantago lanceolata) or perennial ryegrass (Lolium perenne). Proceedings of the New Zealand Society of Animal Production 62: 171-173.

PROTABASE RECORD. 2012. Prota 11(1): Medicinal plants/Plantes médicinales 1. Record display. Consultado 23/01/2012. http://database.prota.org/PROTAhtmml/ Plantago\%20lanceolata.

QUINTERO, C.; BOWERS, M.D. 2011. Plant induced defenses depend more on plant age than previous history of damage: Implications for plantherbivore interactions. Journal of Chemical Ecology 37(9): 992-1001.

ROBERTSON, H.A.; NIEZEN, J.H.; WAGHORN, G.C.; CHARLESTON, W.A.G.; JINLONG, M. 1995. The effect of six herbages on liveweight gain, wool growth and faecal egg count of parasitised ewe lambs. New Zealand Society of Animal Production 55: 199-201. 
ROWARTH, J. 1990. Plantain seed production in a radial trial. Proceedings of the New Zealand Grassland Association: 52: 103-106.

RUMBALL, W.; KEOGH, R. G.; LANE, G.E., MILLER, J.E.; CLAYDON, R.B. 1997. Grassland Lancelot plantain (Plantago lanceolata L.). New Zealand Journal of Agricultural Research 40: 373-377.

SAGAR, G.R. 1962. The effect of S23 ryegrass on the establishment and growth of three species of plantains Plantago lanceolata, P. major, P. media. Annals of Applied Biology 50: 352.

SAGAR, G.R.; HARPER, J.L. 1964. Biological flora of the British Isles. Plantago major L., P. media L. and P. lanceolata L. Journal of Ecology 58:189-221.

SANDERSON, M.; LABREVEUX, M.; HALL, M.; ELWINGER, G. 2002. Nutritive value of Chicory and English Plantain forage. Crop Science 43: 1797-1804.

STEWART, A.W. 1996. Plantain (Plantago lanceolata) a potential pasture species. Proceedings of the New Zealand Grassland Association 58: 77-86.
SUCKLING, F.E.T. 1960. Productivity of pasture species on hill country. New Zealand Journal of Agricultural Research 3: 579-591.

TILEY, G.E.D.; FRANCE, J. 1990. An agronomic evaluation of forage herbs in grassland. Soilgrassland- animal relationships. Proceedings of the 13th General Meeting of the European Grassland Federation, Banska Bystrica, Czechoslovakia. V 2:163-166.

TROELSTRA, S.R.; BROUWER, R. 1992. Mineral nutrient concentrations in the soil and in the plant. Kuiper, P.J.C.; Bos, M. (eds). Ecological Studies Analysis and Synthesis, V 89. Plantago: a multidisciplinary study. Berlin: SpringerVerlag. pp. 122-137.

VOLESKY, J.D. 1996. Forage production and grazing management of chicory. Journal of Production Agriculture 9: 403-406.

WILMAN, D.; RILEY, J.A. 1993. Potential nutritive value of a wide range of grassland species. Journal of Agricultural Science 120: $43-49$. 


\title{
UTILIZACIÓN DE VERDEOS DE VERANO EN LA ALIMENTACIÓN DE CORDEROS
}

\author{
W. Ayala ${ }^{1}$, E. Barrios ${ }^{2}$ \\ J. Magallanes ${ }^{3}$, M. Paiva ${ }^{3}$
}

\section{RESUMEN}

\begin{abstract}
La utilización de verdeos de verano es una alternativa en la alimentación de corderos que permite manejar cargas elevadas durante los meses de verano, aunque los niveles de productividad individual son reducidos. Al mismo tiempo se exploraron los efectos de la sombra y del vellón en la performance de los corderos, no detectándose diferencias entre animales esquilados o no esquilados y aquellos que tenían o no acceso a sombra artificial. En base a los resultados, los verdeos de verano no resultan una alternativa ventajosa en la búsqueda de lograr altas performances individuales y terminación de los animales en el verano.
\end{abstract}

Palabras clave: verdeos, verano, corderos, sombra, esquila

\section{INTRODUCCIÓN}

Los verdeos de verano son frecuentemente utilizados en diferentes sistemas productivos, como un complemento forrajero de alta oferta en los meses de verano. Este trabajo pretende recopilar información sobre la performance de corderos sobre este tipo de pastura, incluyendo además aspectos relacionados a los efectos de la presencia o no de vellón y del acceso a sombra en la performance animal.

\section{CARACTERÍSTICAS DEL SORGO}

El sorgo es una especie de origen tropical, del tipo C4, muy eficiente en la producción de materia seca, pudiendo rendir entre 13 y 20 t/ha MS o aún más cuando no se pastorea y se destina para ensilar. Es tolerante a los déficits hídricos, con capacidad de crecer en variados tipos de suelos, aunque su producción puede verse comprometi- da frente a períodos prolongados de anegamiento.

Aún cuando se destaca su rusticidad, responde a condiciones adecuadas de preparación de la cama de siembra y fertilización, mejorando sustancialmente su establecimiento y entrega inicial de forraje. Dada su alta productividad en el verano, admite una amplitud de usos como pastoreo, cortes, henificación, y ensilaje (Carámbula 1977, Carámbula 1998, Fassio et al., 2002). Puede ser sembrado desde mediados de octubre a diciembre, viéndose favorecido por temperaturas entre 18 y $20^{\circ} \mathrm{C}$.

Se dispone de numerosas variedades de híbridos comerciales en el mercado, los cuales pueden agruparse en los siguientes tipos (CIAAB, 1971, citado por Magallanes y Paiva, 2007):

a) Variedades e híbridos de sudangrás, que presentan como características principales, tallos finos, alto grado de macollaje, adecuada recuperación y rebrote después del pastoreo y resistencia al pisoteo.

\footnotetext{
${ }^{1}$ Ing. Agr., PhD, Programa Nacional Pasturas y Forrajes, INIA. Director Regional INIA Treinta y Tres.

${ }^{2}$ Técnico en Sistemas Intensivos de Producción Animal, Programa Nacional Pasturas y Forrajes, INIA.

${ }^{3}$ Estudiantes de Grado Fac. Agronomía hasta 2007.
} 
b) Híbridos tipo sudan (originados por el cruzamiento de una línea de sudangrás como fuente de polen con sorgo granífero macho estéril). Presentan como el grupo anterior, características adecuadas para pastoreo, pero son mejor adaptados para ensilar.

c) Híbridos doble propósito (graníferoforrajero), de altos rendimientos en grano y alta producción de forraje.

d) Variedades e híbridos de tipo azucarado, especialmente aptos para silo, de gran rendimiento en forraje verde, de tallos jugosos y dulces.

Más recientemente, han comenzado a utilizarse en el mercado los sorgos BMR (de nervadura marrón), que se caracterizan por tener un gen marcador con las características de escasa lignina y alta digestibilidad. Se han encontrado una serie de ventajas como son la mejora en el consumo voluntario de los animales, una mayor tasa de pasaje y un mayor índice de preferencia (Martín, 2005).

Es recomendable iniciar los pastoreos cuando el cultivo llegue a los $60-70 \mathrm{~cm}$ de altura lo cual se da entre 40-50 días post siembra en condiciones normales, manejando rotaciones con cargas altas e intervalos de descanso de entre 20 y 30 días (Carámbula, 1998).

Los sorgos forrajeros contienen un glucósido, la diurrina, precursor del ácido cianhídrico. Este agente tóxico puede llegar a intoxicar a los rumiantes si no se toman las debidas precauciones. Los mayores contenidos de esta toxina se manifiesta cuanto más joven y menor es la altura de la planta, con la mayor intensidad de luz, cuando hay detención del crecimiento por sequías o heladas, o con el agregado de altas cantidades de nitrógeno al suelo. Además influye la variedad (los sudangrases contienen menos diurrina que los híbridos), el estado del animal y la dieta previa (CIAAB, 1971).

Como medidas preventivas se recomienda (CIAAB, 1971):

a) No pastorear hasta que el cultivo alcance $50-70 \mathrm{~cm}$ de altura, evitando el pastoreo de plantas jóvenes. b) Para evitar la toxicidad del rebrote, no bajar la altura del rastrojo a menos de $15 \mathrm{~cm}$.

c) Dejar envejecer los rebrotes posteriores a pastoreos o cortes intensos.

d) Retirar los animales por algunos días cuando, por una lluvia luego de un período seco, el sorgo rebrota rápidamente.

\section{POTENCIAL PARA PRODUCCIÓN DE CARNE OVINA}

Dentro de los antecedentes disponibles es posibles mencionar el trabajo de Parma (1997), quien con corderos Corriedale, a partir de fines de diciembre sobre un verdeo de sudangrás Estanzuela Comiray, con cargas de 40 an/ha, determinó una ganancia diaria de 34 g/an/día.

Por su parte, Montossi y col. (2004), en la Unidad Experimental de Glencoe - INIA Tacuarembó, sobre un sorgo forrajero por un período de 72 días entre fines de diciembre y mediados de marzo, utilizando cargas de 30 y 50 corderos/ha, obtuvieron ganancias de 57 y $64 \mathrm{~g} / \mathrm{an} /$ día respectivamente. Otros trabajos realizados durante 73 días entre fines de diciembre y principios de marzo, permitieron alcanzar ganancias de 85, 54 y 20 g/an/día con cargas de 37,5, 54,2 y 70,4 corderos respectivamente.

En la región este de Uruguay, Ayala y Bermúdez (2005), evaluando un cultivo de sudangrás en la Unidad Experimental de Palo a Pique durante 28 días en el mes de enero, con una carga de 88 an/ha obtuvieron una ganancia diaria de $63 \mathrm{~g} / \mathrm{an} /$ día y un peso vivo de $155 \mathrm{~kg} / \mathrm{ha}$.

\section{RESULTADOS}

\section{Experimento 1}

Para el mismo se utilizaron dos variedades de sudangrás: INIA Surubí y Estanzuela Comiray sembradas el $1^{\circ}$ de diciembre a razón de $20 \mathrm{~kg} / \mathrm{ha}$ y fertilizadas a la base con $150 \mathrm{~kg} / \mathrm{ha}$ de 9-40/40-13, comenzando los 
pastoreos el 4 de febrero. El mismo se extendió por 28 días, hasta el 3 de marzo, utilizando una carga de 48 corderos/ha. Al inicio del pastoreo, 66 días post-siembra, no se detectaron diferencias entre los dos cultivares evaluados en su aporte de materia de seca. En promedio el disponible inicial entre ambas variedades fue de 1,8 t/ha MS, con $56 \%$ de hojas y $44 \%$ de tallos (Cuadro 1). En un área donde se evaluó la capacidad de acumulación de materia seca, INIA Surubí superó a Estanzuela Comiray, llegando a máximos en toda la estación de crecimiento en torno a las 15 t/ha MS (Magallanes y Paiva, 2007).

La disponibilidad de MS/ha, las diferentes fracciones y el desperdicio al 17/02/05, no presentaron diferencias estadísticas entre variedades. Se registró una tendencia $(p=0,06)$ a favor de INIA Surubí en disponibilidad total y en cada fracción (hojas y taIlos). En promedio el disponible total fue de 4,0 t/ha MS, con $25 \%$ de hojas y $75 \%$ de tallo. El desperdicio que se encontró cortado y pisoteado en el suelo fue de 0,6 t/ha MS (Cuadro 1). Al finalizar el experimento (03/03/05), no se registraron diferencias significativas entre variedades en el remanente total, en la fracción tallo y en el desperdicio. Para la fracción hoja se encontraron diferencias significativas $(p<0,05)$ a favor de INIA
Surubí, el remanente de esta variedad fue de 6,0 t/ha MS, compuesto por $19 \%$ de hojas y $81 \%$ de tallos. El remanente de Estanzuela Comiray fue de $2,112 \mathrm{t} / \mathrm{ha}$ MS, con $11 \%$ de hojas y $89 \%$ de tallos (Cuadro 1). Cabe destacar que si bien existen diferencias marcadas en los rendimientos, aunque no se detectan mayores diferencias a consecuencia de la variabilidad entre tratamientos, producto de los patrones de pastoreo que siguen los animales, estableciéndose áreas sobrepastoreadas y subpastoreadas.

No se registraron efectos de los factores estudiados (vellón y sombra) sobre la utilización de la pastura.

Las ganancias diarias sobre el sudangrás no presentaron diferencias significativas para ninguno de los factores estudiados (Cuadro 2). En promedio la ganancia diaria fue de 117 g/an/día para todo el período de pastoreo.

Los corderos con acceso y sin acceso a sombra alcanzaron la misma producción de carne al final del período (Figura 1). En cambio, a pesar de que no se registraron diferencias significativas para el factor vellón, los corderos esquilados alcanzaron una producción de carne $22 \%$ mayor que los corderos sin esquilar. En promedio la producción de carne sobre el sudangrás fue de $158 \mathrm{~kg} / \mathrm{ha}$ (Cuadro 2).

Cuadro 1. Disponibilidad de MS total, sus distintas fracciones: hojas y tallos, y desperdicio según variedad (t/ha MS), (Magallanes y Paiva, 2007).

\begin{tabular}{|l|l|c|c|c|c|}
\hline Fecha & $\begin{array}{c}\text { Variedad } \\
\text { (t/ha MS) }\end{array}$ & $\begin{array}{c}\text { Total } \\
\text { (t/ha MS) }\end{array}$ & $\begin{array}{c}\text { Hoja } \\
\text { (t/ha MS) }\end{array}$ & $\begin{array}{c}\text { Tallo } \\
\text { (t/ha MS) }\end{array}$ & Desperdicio \\
\hline 04/02/2005 & Estanzuela Comiray & 16 & 1 & 0,6 & - \\
& INIA Surubí & 2 & 0,9 & 1 & - \\
Significancia & & $\mathrm{ns}$ & $\mathrm{ns}$ & $\mathrm{ns}$ & - \\
\hline 17/02/2005 & Estanzuela Comiray & 2,7 & 0,7 & 2 & 0,5 \\
& INIA Surubí & 5,2 & 1,3 & 4 & 0,6 \\
Significancia & & $\mathrm{p}=0,06$ & $\mathrm{p}=0,06$ & $\mathrm{p}=0,06$ & $\mathrm{~ns}$ \\
\hline 03/03/2005 & Estanzuela Comiray & 2,1 & 0,2 & 1,9 & 1,1 \\
& INIA Surubí & 6,0 & 1,1 & 4,9 & 0,8 \\
Significancia & & $\mathrm{ns}$ & $*$ & $\mathrm{~ns}$ & $\mathrm{~ns}$ \\
\hline
\end{tabular}

${ }^{*}=p<0,05$; ns: diferencias estadísticas no significativas. 
Cuadro 2. Ganancia diaria y producción de peso vivo de corderos sobre sudangrás entre el 4 de febrero y el 3 de marzo (adaptado de Magallanes y Paiva, 2007).

\begin{tabular}{|l|l|c|c|}
\hline Tratamientos & & $\begin{array}{c}\text { Ganancia diaria } \\
\text { (g/an/día) }\end{array}$ & $\begin{array}{c}\text { Peso vivo } \\
\text { (kg/ha) }\end{array}$ \\
\hline \multirow{2}{*}{ Efecto vellón } & Sin esquilar & 103 & 139 \\
\cline { 2 - 4 } & Esquilados & 132 & 178 \\
\hline \multirow{2}{*}{ Efecto sombra } & Con sombra & 117 & 158 \\
\cline { 2 - 4 } & Sin sombra & 118 & 158 \\
\hline Significancia & & & $\mathrm{ns}$ \\
\hline Efecto vellón & & $\mathrm{ns}$ & $\mathrm{ns}$ \\
\hline Efecto sombra & & $\mathrm{ns}$ & $\mathrm{ns}$ \\
\hline Interacción vellón x sombra & & $\mathrm{ns}$ & $\mathrm{ns}$ \\
\hline Efecto bloque & & $\mathrm{ns}$ & \\
\hline
\end{tabular}

ns: diferencias estadísticas no significativas $(p>0,05)$.
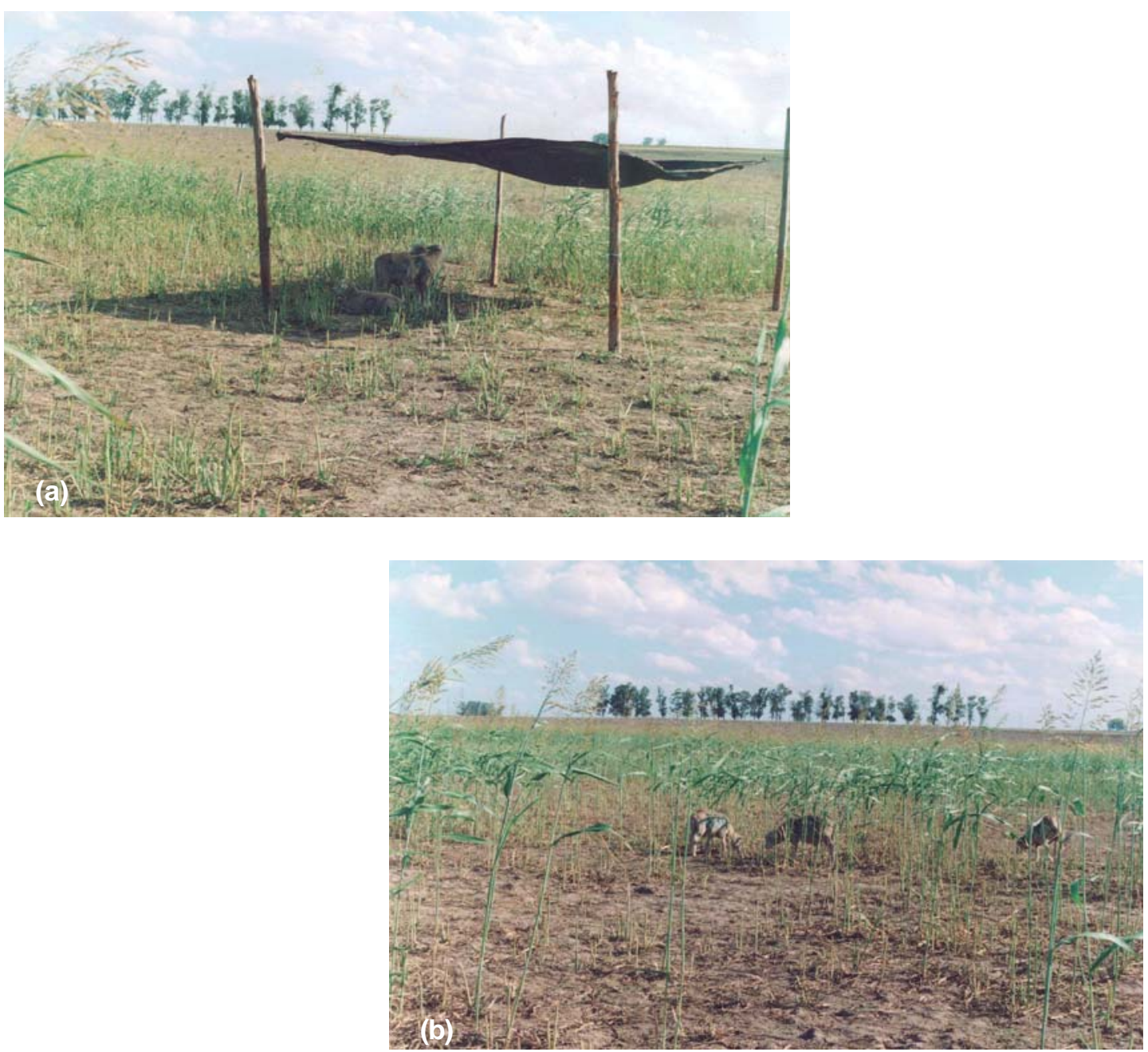

Figura 1. Los animales utilizaron la sombra en los períodos de mayor radiación (a), y aquellos sin acceso a sombra tendieron a refugiarse dentro del cultivo (b). 


\section{Experimento 2}

Para el estudio se utilizaron 56 corderos Corriedale castrados, de 4 meses de edad con un peso vivo inicial promedio de 26,7 \pm $2,2 \mathrm{~kg}$ (Magallanes y Paiva, 2007). Se utilizó un cultivo de sudangrás INIA Surubí sembrado el 23 de noviembre, que comenzó a ser pastoreado el 10 de enero en forma alterna con cambios cada 14 días, permitiendo completar dos ciclos de pastoreo manejando una carga de 41 an/ha. El cultivo se sembró a una densidad de $18 \mathrm{~kg} / \mathrm{ha}$ de semilla y con una fertilización a la base de $150 \mathrm{~kg} / \mathrm{ha}$ de 9-40/40-13. El trabajo consistió en evaluar los efectos de la sombra y el vellón en la performance de los animales, para lo cual se establecieron cuatro tratamientos (corderos esquilados sin sombra, corderos esquilados con sombra, corderos sin esquilar con sombra, corderos sin esquilar sin sombra), en dos repeticiones utilizando 7 animales por tratamiento, con libre acceso al agua. La sombra utilizada fue artificial, para lo cual se dispuso de malla de $80 \%$ de intersección, a una altura de 1,85 m (Magallanes y Paiva, 2007).

La disponibilidad fue de 1,3 t/ha MS al inicio del período experimental, siendo a los 14 días al pasar a la segunda subparcela 9,8 t/ha MS, lo que significó un aumento de 7,5 veces la disponibilidad inicial. La propor- ción de hojas y tallos varió entre los momentos, siendo de $58 \%$ hojas y $42 \%$ tallos en la primer subparcela y $42 \%$ hojas y $58 \%$ tallos en la segunda subparcela. En el segundo pastoreo la disponibilidad fue de 4,5 y 10,6 t/ha MS para la primer y segunda subparcela respectivamente, siendo la proporción de hojas y de tallos prácticamente la misma (24\% hojas y $76 \%$ tallos en la primera y $22 \%$ hojas y $78 \%$ tallos en la segunda subparcela). El momento de entrada es determinante, debido a los cambios en las tasas de crecimiento y relaciones hoja/tallo que se registran.

Los efectos de la sombra fueron a favor de los corderos con acceso a la misma, éstos utilizaban más la pastura que los corderos que carecían de sombra. Una única vez se encontró efecto del vellón, los corderos sin esquilar realizaron una mejor utilización de la pastura, tendiendo $(p=0,06)$ a lograr mayores ganancias de peso (Magallanes y Paiva, 2007).

Los pesos vivos alcanzados no permitieron terminar los animales (Cuadro 3 ). Las ganancias diarias logradas fueron de $67 \mathrm{~g} / \mathrm{an} / \mathrm{día}$ (Cuadro 4), no existiendo efecto de la sombra o del vellón sobre las mismas. Estas ganancias concuerdan con las reportadas por Montossi y col. (2004), aunque fueron mayores que las registradas por Parma (1997).

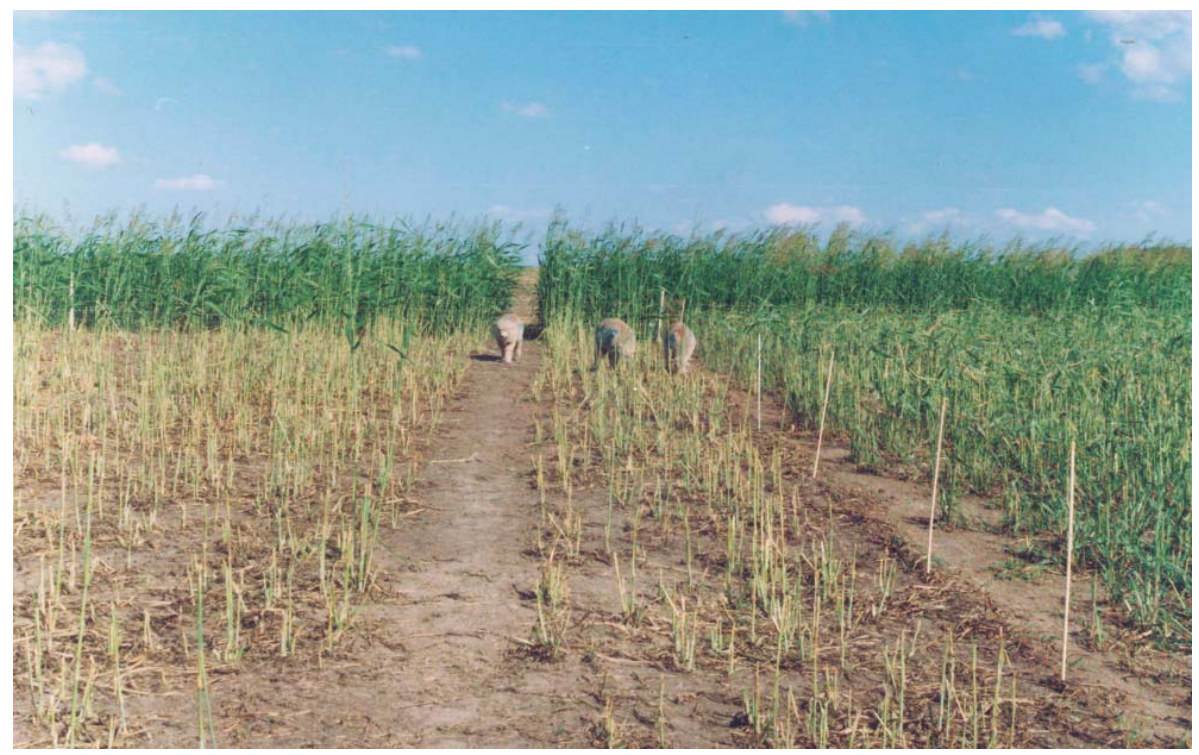

Figura 2. Remanente del verdeo pastoreado por corderos en verano. 
Cuadro 3. Evolución de peso vivo de corderos sobre sudangras entre el 10 de enero y el 8 de marzo (Magallanes y Paiva, 2007).

\begin{tabular}{|c|c|c|c|c|c|c|}
\hline \multirow[t]{2}{*}{ Tratamientos } & & \multicolumn{5}{|c|}{ Peso Vivo (kg/an) } \\
\hline & & 10-ene & 25-ene & 08-feb & 22-feb & 08-mar \\
\hline \multirow[t]{2}{*}{ Efecto vellón } & Sin esquilar & 27,7 & 29,4 & 30,1 & 31,7 & 30,9 \\
\hline & Esquilados & 25,8 & 27,5 & 29,4 & 30,5 & 29,2 \\
\hline \multirow[t]{2}{*}{ Efecto sombra } & Con sombra & 26,6 & 30,2 & 30,2 & 31,7 & 29,8 \\
\hline & Sin sombra & 26,8 & 29,3 & 29,3 & 30,6 & 30,3 \\
\hline \multicolumn{7}{|l|}{ Significancia } \\
\hline Efecto vellón & & *夫 & *夫 & ns & * & * \\
\hline Efecto sombra & & ns & ns & ns & ns & ns \\
\hline Interacción vellón x sombra & & ns & ns & ns & ns & ns \\
\hline Efecto bloque & & ns & ns & ns & ns & ns \\
\hline
\end{tabular}

${ }^{*}=p<0,05 ;{ }^{* *}=p<0,01 ;$ ns: diferencias estadísticas no significativas.

Cuadro 4. Ganancia diaria y producción de peso vivo de corderos sobre sudangras entre el 10 de enero y el 8 de marzo (adaptado de Magallanes y Paiva, 2007).

\begin{tabular}{|l|l|c|c|}
\hline \multirow{2}{*}{ Tratamientos } & & $\begin{array}{c}\text { Ganancia diaria } \\
\text { (g/an/día) }\end{array}$ & $\begin{array}{c}\text { Peso vivo } \\
\text { (kg/ha) }\end{array}$ \\
\hline \multirow{2}{*}{ Efecto vellón } & Sin esquilar & 76 & 181 \\
\cline { 2 - 4 } & Esquilados & 58 & 139 \\
\hline \multirow{2}{*}{ Efecto sombra } & Con sombra & 69 & 165 \\
\cline { 2 - 4 } & Sin sombra & 65 & 155 \\
\hline Significancia: & & & $\mathrm{ns}$ \\
\hline Efecto vellón & & $\mathrm{p}=0,06$ & $\mathrm{~ns}$ \\
\hline Efecto sombra & & $\mathrm{ns}$ & $\mathrm{ns}$ \\
\hline Interacción vellón $\times$ sombra & & $\mathrm{ns}$ & $\mathrm{ns}$ \\
\hline Efecto bloque & & $\mathrm{ns}$ & \\
\hline
\end{tabular}

ns: diferencias estadísticas no significativas.

La producción de peso vivo tampoco presentó diferencias entre tratamientos, teniendo un valor promedio de $160 \mathrm{~kg} / \mathrm{ha}$.

\section{CONCLUSIONES}

De acuerdo a los antecedentes revisados y lo ocurrido en ambos experimentos se puede afirmar que a pesar de lo impredecible del clima, el sudangrás permite mantener altas cargas, con ganancias individuales que no permiten un engorde rápido de los corderos. Bajo las condiciones que se realizaron estos experimentos no se encontraron beneficios por efecto de la sombra sobre la per- formance animal. Otros trabajos realizados por Banchero y Montossi (1998) y Banchero y col. (2005) coinciden con estos resultados, sin embargo Olivares y Caro (1998) sí registraron diferencias significativas en las ganancias de peso debido a la sombra. Por su parte, Rovira (2002) en un ensayo de engorde de novillos en el periodo estival obtuvo mejores performances en aquellos animales que tenían acceso a la sombra.

Con respecto al efecto del vellón sobre las ganancias diarias, no se presentaron diferencias como consecuencia de este factor en ninguno de los experimentos, por lo que los resultados concuerdan con Banchero y 
col. (2005), quienes aseguran que esquilar los corderos sólo presentaría una ventaja productiva en aquellos predios que tengan problemas de flechilla.

Aunque no se hayan registrado beneficios por efecto de la sombra, los corderos siempre hicieron uso de ella, en los horarios de mayor temperatura se observó que los animales que no tenían acceso a la sombra permanecían agitados y jadeando, mientras que los que tenían acceso a sombra presentaban un estado más confortable. Por eso, si se piensa en bienestar animal, es importante que los corderos dispongan de sombra en las parcelas. En este caso, es posible que haya existido un efecto de sombreado por parte del sudangrás, dado el porte alcanzado que quizás haya anulado en parte los efectos de la sombra en esta pastura.

\section{BIBLIOGRAFÍA}

AYALA, W.; BERMÚDEZ, R. 2005. Alternativas de alimentación en la recría de corderos durante el verano. INIA. Producción Animal-Unidad Experimental Palo a Pique. Montevideo, INIA. Actividades de Difusión $\mathrm{N}^{\circ}$ 429. pp. 33-37.

BANCHERO, G.; MONTOSSI, F. 1998. Engorde intensivo de corderos. Jornada de Ovinos y Pasturas (1998, La Estanzuela, Colonia). Uso alternativo de concentrados, ensilajes y/o pasturas mejoradas. Montevideo, INIA. Actividades de Difusión $\mathrm{N}^{\circ}$ 167. pp 17-25.

BANCHERO, G; FERNÁNDEZ, M. F.; GANZÁBAL, A. 2005. Algunas estrategias al momento de engordar corderos pesados. INIA. Día de campo: Producción ovina intensiva. Serie Actividades de Difusión No 426. pp. 9-15.

CARÁMBULA, M. 1977. Producción y manejo de pasturas sembradas. Montevideo, Hemisferio Sur. 464 p.
CARÁMBULA, M. 1998. Producción y manejo de pasturas sembradas. Montevideo, Hemisferio Sur. Reimpresión. 464p.

CIAAB (Centro de Investigaciones Agrícolas «Alberto Boerger». Uruguay. Ministerio de Ganadería y Agricultura). 1971. Sorgo granífero. Boletín de Divulgación $\mathrm{N}^{\circ} 15.22 \mathrm{p}$.

FASSIO, A.; COZZOLINO, D.; IBAÑEZ, W.; FERNÁNDEZ, E. 2002. Sorgo para destino forrajero. Montevideo, INIA. Serie Técnica $\mathrm{N}^{\circ}$ 127. 27 p.

MAGALLANES, J.; PAIVA, M. 2007. Efecto de la sombra y el vellón en la performance de corderos en el verano. Tesis de grado. Facultad de Agronomía, UDELAR. 81 p.

MARTíN, G. 2005. Cultivos: Sorgos forrajeros, la nueva generación. http:// www.produccion.com.ar/2005/ 05ago_11.htm. Consultado $21 \mathrm{de}$ octubre de 2013.

MONTOSSI, F.; SAN JULIÁN, R.; MEDEROS, A.; DE BARBIERI, I.; DIGHIERO, A.; NOLLA, M.; LUZARDO, S.; BANCHERO, G. 2004. Tecnología en engorde de corderos pesados en verano sobre pasturas cultivadas para basalto. INIA. Día de Campo. Producción animal en suelos de basalto. Serie Actividades de Difusión No. 377. pp. 36-37.

OLIVARES, A.; CARO, T, W. 1998. Efecto de la presencia de sombra en el consumo de agua y ganancia de peso de ovinos en pastoreo. Agrosur 26 (1). pp. 77-80.

PARMA, R. 1997. Utilización de sudangrás para el engorde de corderos. Producción Ovina 10: pp. 75-78.

ROVIRA, P. 2002. Efecto de la sombra artificial en el engorde de novillos durante los meses de verano. INIA. Serie Actividades de Difusión N. 294. pp. 79-95. 



\title{
ALTERNATIVAS FORRAJERAS ESTIVALES PARA LA PRODUCCIÓN DE CORDEROS: LEGUMINOSAS
}

\author{
E. Barrios ${ }^{1}$, W. Ayala ${ }^{2}$ \\ R. Bermúdez ${ }^{3}$, J. Magallanes ${ }^{4}$ \\ Mauricio Paiva ${ }^{4}$
}

\section{RESUMEN}

Lotus corniculatus y Trifolium pratense son dos leguminosas que pueden contribuir en forma efectiva en procesos productivos demandantes de alta calidad de forraje como es la alimentación de corderos durante el período estival. Desde el punto de vista forrajero, su uso debe propender a manejos acordes a los efectos de no afectar su persistencia en momentos críticos como el verano, donde las condiciones hídricas pueden condicionar el crecimiento de las pasturas. Desde el punto de vista animal, es posible, manejando adecuadamente la carga, alcanzar performances individuales que permitan cumplir con el objetivo de producir un cordero precoz pesado hacia fines de verano.

Palabras clave: Lotus, Trébol rojo, utilización, ovino

\section{INTRODUCCIÓN}

En la región este los mejoramientos de campo han sido una tecnología probada y que ha generado mejoras sustanciales en la oferta forrajera en cantidad y calidad. Sin embargo, los manejos más apropiados hacen hincapié en el cuidado durante los meses de verano, período clave en la resiembra natural de las especies introducidas. Asimismo, las condiciones hídricas durante el verano condicionan la persistencia y restringen el potencial forrajero.

Es por ello, que tratando de compatibilizar las alternativas forrajeras más tradicionales, que puedan cubrir las demandas generadas en el verano para ovinos, se identifica a Lotus corniculatus (Iotus) y Trifolium pratense L. (trébol rojo) como aquellas más apropiadas. No obstante, resulta clave introducir el concepto de pastura especializada en el contexto antes mencionado, apostando a que sean pasturas que lleguen vigorosas a fines de primavera de manera tal que puedan hacer una alta contribución durante el verano.

Lotus corniculatus se adapta a un amplio rango de suelos, en particular ácidos, poco fértiles, secos o de drenaje pobre (Douglas y Foote, 1993). Se puede considerar como una especie con un buen potencial de producción de forraje primavero-estivo-otoñal y un valor nutritivo destacable a causa de la presencia de taninos condensados. En breve, se puede decir que la mayor producción ocurre en primer término en primavera y luego en verano (Rebuffo, 1991). Esta especie es sensible a la intensidad y frecuencia de los pastoreos, viéndose favorecida con pastoreos controlados. Los efectos de la intensidad de defoliación a través del tiempo se traducen en una reducción del tamaño de las coronas de las plantas, masa de raíces, diámetro de la raíz y carbohidratos de reserva, lo que afecta tanto la productividad como la persistencia de la especie (Ayala, 2001). El cultivar tradicionalmente más utilizado es San Gabriel, que tiene una amplia

\footnotetext{
${ }^{1}$ Téc. en Sistemas Intensivos de Programa Animal, Programa Nacional Pasturas y Forrajes, INIA. ${ }^{2}$ Ing. Agr., PhD, Programa Nacional Pasturas y Forrajes, INIA. Director Regional INIA Treinta y Tres.

${ }^{3}$ Ing. Agr., MPhil, Programa Nacional Pasturas y Forrajes, INIA.

${ }^{4}$ Estudiantes de Grado Fac. Agronomía hasta 2007.
} 
adaptación al medio. El programa de mejoramiento genético de forrajeras de INIA ha liberado los cultivares INIA Draco con mayor aporte estival y Rigel un tipo más postrado con muy buena sanidad y mayor aporte que San Gabriel (Ayala y col., 2010).

En referencia a Trifolium pratense, se encuentran en el mercado tres tipos de cultivares en función de su nivel de latencia invernal (Ayala y col., 2010). El trébol rojo es considerada una forrajera bianual, utilizada en rotaciones cortas, aunque puede ser instalada en siembras de cobertura. Mirado desde la perspectiva de la producción estival, los cultivares que realizan un mayor aporte en verano son aquellos con latencia invernal, aunque su producción puede verse limitada en condiciones de sequía. Por otra parte, es una de las especies que responde mejor al riego, siendo una alternativa tecnológica a tener en cuenta cuando se considera su aporte en verano. Trébol rojo Estanzuela 116, es el cultivar más usado, aunque el Programa de Mejoramiento Genético de Forrajeras de INIA ha liberado en los últimos tiempos los cultivares INIA Mizar y Antares. INIA Mizar destaca por su aporte estival, y tolerancia a enfermedades de raíz y corona, mientras que Antares además presenta una buena sanidad foliar con una muy buena producción en el segundo año (Ayala y col., 2010).

En la búsqueda de alternativas de leguminosas que contribuyan a mejorar la performance de corderos en el verano, resulta oportuno presentar información ya generada en la región este sobre la utilización de estas leguminosas.

\section{Resultados de producción de carne sobre Lotus corniculatus}

Se presenta la información recabada y publicada por Ayala y col. (2007) que resume un ensayo realizado en la Unidad

Experimental Palo a Pique, de INIA Treinta y Tres, sobre un argisol subeútrico de la unidad de suelos Alférez, por un período de 97 días entre el 26/12/06 y el 2/04/07. Se utilizó un potrero de 1,46 ha de Lotus corniculatus cv. INIA Draco, sembrado en
2002 y resembrado en mayo de 2006 a razón de $8 \mathrm{~kg} / \mathrm{ha}$ y fertilizado anualmente con 60 unidades de $\mathrm{P}_{2} \mathrm{O}_{5}$ de fosforita natural. Se evaluó el efecto de la carga animal $(10,20$ y $30 \mathrm{an} / \mathrm{ha}$ ) en la performance de corderos cruza Texel nacidos en la primavera 2006 y que al comienzo de la evaluación registraban un peso de 25,1 $\pm 2,0 \mathrm{~kg} / \mathrm{an}$, utilizando un diseño en bloques al azar con dos repeticiones. Se manejaron 4 animales por repetición ajustando la carga en función del área de pastoreo. El sistema de pastoreo empleado fue rotativo de tres parcelas con tiempos de ocupación y descanso de 10 y 20 días respectivamente, totalizando en el período experimental tres ciclos de pastoreos (Ciclo 1: 26/12-30/01, Ciclo 2: 30/01-2/03, Ciclo 3: 2/03-2/04). En la pastura se tomaron determinaciones de forraje disponible, remanente post pastoreo, altura, determinación de materia seca, composición botánica y valor nutritivo. Los animales se pesaron al inicio del ensayo y luego cada 10 días, coincidiendo con el cambio de parcelas. Al final de la evaluación se faenaron los animales realizándose determinaciones de calidad de carne post mortem (peso canal caliente y fría, GR, rendimiento, pierna sin hueso y frenched rack así como la tipificación de las canales: conformación y terminación).

\section{Producción de forraje}

El forraje disponible inicial se situó en $3,5 \mathrm{t} / \mathrm{ha}$ MS en promedio, con una contribución de lotus del 78\%. Durante el primer ciclo de pastoreo no se registraron diferencias en el promedio de los niveles de oferta, altura, contribución de lotus, relación hoja/tallo y relación verde/seco del disponible (Cuadro 1). Se destaca el estado de la pastura $(>70 \%$ de lotus, $>20 \mathrm{~cm}$ de altura, alta proporción de tallos y baja proporción de restos secos). Luego de finalizado el primer ciclo de pastoreo, se determinaron diferencias en el forraje remanente como consecuencia de la diferente intensidad de los mismos, disminuyendo la cantidad de forraje, la altura y la proporción de lotus con el incremento de la carga. Asimismo, se acrecienta aún más la proporción de tallos sobre la de hojas y disminuye la relación verde/seco lo que muestra la capacidad selectiva de los corderos. 
Hacia el segundo ciclo de pastoreo, se continuan las diferencias encontradas en los remanentes del primer ciclo, lo que sumado a los efectos climáticos registrados que redujeron el crecimiento y las relaciones hoja/ tallo y verde/seco (Cuadro 1), decaen con el aumento de carga.
Para el tercer ciclo, las lluvias permitieron una mejora en los niveles de disponibilidad, y en los parámetros relacionados a la calidad de la pastura (relaciones hoja/tallo y verde/seco). Se detectó una pérdida de forraje en general para todos los tratamientos entre el remanente del segundo ciclo y el

Cuadro 1. Resultados promedio de la pastura para cada uno de los tres ciclos de pastoreo en términos de disponibilidad, altura, relación hoja/tallo y verde/seco (Ayala y col., 2007).

\begin{tabular}{|c|c|c|c|c|c|}
\hline & \multirow[t]{2}{*}{ Variables } & \multicolumn{3}{|c|}{ Carga an/ha } & \multirow[t]{2}{*}{ Probabilidad } \\
\hline & & 10 & 20 & 30 & \\
\hline \multirow[t]{10}{*}{ Ciclo 1} & Forraje disponible (t/ha MS) & 4 & 3,5 & 4 & ns \\
\hline & Altura disponible (cm) & 25 & 22 & 24 & ns \\
\hline & Lotus disponible (\%) & 81 & 74 & 71 & ns \\
\hline & Relación hoja/tallo disponible & 0,6 & 0,6 & 0,6 & ns \\
\hline & Relación verde/seco disponible & 6,1 & 4,1 & 2,5 & ns \\
\hline & Forraje remanente (t/ha MS) & $3,3 \mathrm{a}$ & $2,3 \mathrm{a}$ & $2,2 \mathrm{~b}$ & ** \\
\hline & Altura remanente (cm) & $21 \mathrm{a}$ & $18 a b$ & $14 \mathrm{~b}$ & * \\
\hline & Lotus remanente (\%) & $77 \mathrm{a}$ & $60 \mathrm{~b}$ & $65 a b$ & * \\
\hline & Relación hoja/tallo remanente & $0,3 a b$ & $0,4 \mathrm{a}$ & $0,1 \mathrm{~b}$ & * \\
\hline & Relación verde/seco remanente & $4,1 \mathrm{a}$ & $1,8 \mathrm{~b}$ & $1,0 \mathrm{~b}$ & ** \\
\hline \multirow[t]{10}{*}{ Ciclo 2} & Forraje disponible (t/ha MS) & $4,0 \mathrm{a}$ & $3,7 \mathrm{a}$ & $2,6 \mathrm{~b}$ & ** \\
\hline & Altura disponible $(\mathrm{cm})$ & $27 \mathrm{a}$ & $24 \mathrm{~b}$ & $20 \mathrm{c}$ & ** \\
\hline & Lotus disponible (\%) & 51 & 48 & 44 & ns \\
\hline & Relación hoja/tallo disponible & 0,2 & 0,2 & 0,1 & ns \\
\hline & Relación verde/seco disponible & 1,3 & 1 & 0,9 & ns \\
\hline & Forraje remanente (t/ha MS) & $3,9 \mathrm{a}$ & $2,7 \mathrm{~b}$ & $2,0 \mathrm{~b}$ & ** \\
\hline & Altura remanente $(\mathrm{cm})$ & $18 \mathrm{a}$ & $13 \mathrm{~b}$ & $8 \mathrm{c}$ & ** \\
\hline & Lotus remanente (\%) & $46 \mathrm{a}$ & $25 \mathrm{~b}$ & $31 a b$ & * \\
\hline & Relación hoja/tallo remanente & 0,2 & 1 & 0,03 & ns \\
\hline & Relación verde/seco remanente & $0,9 \mathrm{a}$ & $0,3 \mathrm{~b}$ & $0,2 \mathrm{~b}$ & ** \\
\hline \multirow[t]{10}{*}{ Ciclo 3} & Forraje disponible (t/ha MS) & $2,4 \mathrm{a}$ & $2,0 \mathrm{a}$ & $1,4 \mathrm{~b}$ & $\star \star$ \\
\hline & Altura disponible $(\mathrm{cm})$ & $22 \mathrm{a}$ & $19 \mathrm{~b}$ & $15 \mathrm{c}$ & ** \\
\hline & Lotus disponible (\%) & 74 & 62 & 60 & ns \\
\hline & Relación hoja/tallo disponible & 0,8 & 1,2 & 1,1 & ns \\
\hline & Relación verde/seco disponible & 3,8 & 2 & 1,7 & ns \\
\hline & Forraje remanente (t/ha MS) & $2,1 \mathrm{a}$ & $1,7 \mathrm{a}$ & $1,1 \mathrm{~b}$ & ** \\
\hline & Altura remanente $(\mathrm{cm})$ & $16 \mathrm{a}$ & $11 \mathrm{~b}$ & $8 \mathrm{c}$ & ** \\
\hline & Lotus remanente (\%) & 75 & 49 & 72 & ns \\
\hline & Relación hoja/tallo remanente & $0,5 \mathrm{a}$ & $0,2 b$ & $0,1 b$ & * \\
\hline & Relación verde/seco remanente & 439 & 180 & 196 & ns \\
\hline
\end{tabular}

a b y c $=$ medias con letras distintas en una misma fila son significativamente diferentes entre sí ( ${ }^{*} P<0,05$, ${ }^{* *}=\mathrm{P}<0,01, \mathrm{~ns}=$ diferencia estadísticamente no significativa). 
forraje disponible del tercer ciclo, diferencias que consideradas en el total (incluído el crecimiento del período), determinaron una reducción de los disponibles del tercer ciclo del 31\% en relación a los remanentes previos.

Referido a la disponibilidad, se detectaron diferencias significativas $(P<0,01)$, siendo el tratamiento de $30 \mathrm{an} / \mathrm{ha}$ el que significativamente mostró la menor disponibilidad. Para la altura del forraje se observan diferencias significativas $(P<0,01)$, que reflejan el efecto acumulado de los ciclos de pastoreo previos, donde la altura disminuyó a medida que aumentó la carga (10>20>30 an/ha). Si bien en la composición porcentual dentro de la pastura no se registraron diferencias en la contribución del lotus, en términos absolutos se observó el mismo patrón descrito previamente para altura. Las relaciones hoja/tallo y verde/seco del disponible no fueron afectadas por la carga (Cuadro 1).
Para el forraje remanente final y la altura del mismo se mantuvieron las diferencias observadas en el forraje disponible. Cabe hacer hincapié en las diferencias estadísticas registradas en la relación hoja/tallo del remanente, la cual se incrementó para las cargas más bajas y que sin duda tiene implicancias en la capacidad de rebrote de la pastura.

\section{Performance individual y producción de peso vivo}

Las ganancias diarias de los corderos durante el primer ciclo no fueron afectadas por la carga, alcanzando para el promedio de los tratamientos 191 g/an/día (Cuadro 2).

Para el segundo ciclo, la performance individual en todos los casos se vio resentida sustancialmente, detectándose diferencias significativas entre cargas $(P<0,01)$. Las cargas de 10 y 20 an/ha no se diferenciaron entre sí,

Cuadro 2. Ganancias medias diarias (g/an/día) y producción física (kg/ha) para cada ciclo de pastoreo y totales al final del período experimental de corderos cruza Texel pastoreando Lotus corniculatus durante el verano (Ayala y col., 2007).

\begin{tabular}{|c|c|c|c|c|c|c|c|c|}
\hline \multirow{2}{*}{$\begin{array}{c}\text { Carga } \\
\text { (an/ha) }\end{array}$} & \multicolumn{4}{|c|}{ Ganancias diarias (g/an/día) } & \multicolumn{3}{c|}{ Producción (kg/ha) } \\
\cline { 2 - 9 } & Ciclo 1 & Ciclo 2 & Ciclo 3 & Total Período & Ciclo 1 & Ciclo 2 & Ciclo 3 & Total Período \\
\hline 10 & 208 & $83 \mathrm{a}$ & $158 \mathrm{a}$ & $152 \mathrm{a}$ & $73 \mathrm{c}$ & $26 \mathrm{a}$ & 49 & $147 \mathrm{c}$ \\
20 & 171 & $65 \mathrm{a}$ & $165 \mathrm{a}$ & $135 \mathrm{a}$ & $120 \mathrm{~b}$ & $41 \mathrm{a}$ & 103 & $263 \mathrm{a}$ \\
30 & 193 & $-46 \mathrm{~b}$ & $51 \mathrm{~b}$ & $71 \mathrm{~b}$ & $202 \mathrm{a}$ & $-43 \mathrm{~b}$ & 48 & $206 \mathrm{~b}$ \\
\hline Probab. & $\mathrm{ns}$ & $* *$ & $*$ & $* *$ & $* *$ & $* *$ & $\mathrm{~ns}$ & $*$ \\
\hline
\end{tabular}

a b y c $=$ medias con letras distintas en una misma columna son significativamente diferentes entre sí ( ${ }^{*} P<0,05$, $* *=\mathrm{P}<0,01, \mathrm{~ns}=$ diferencia estadísticamente no significativa).

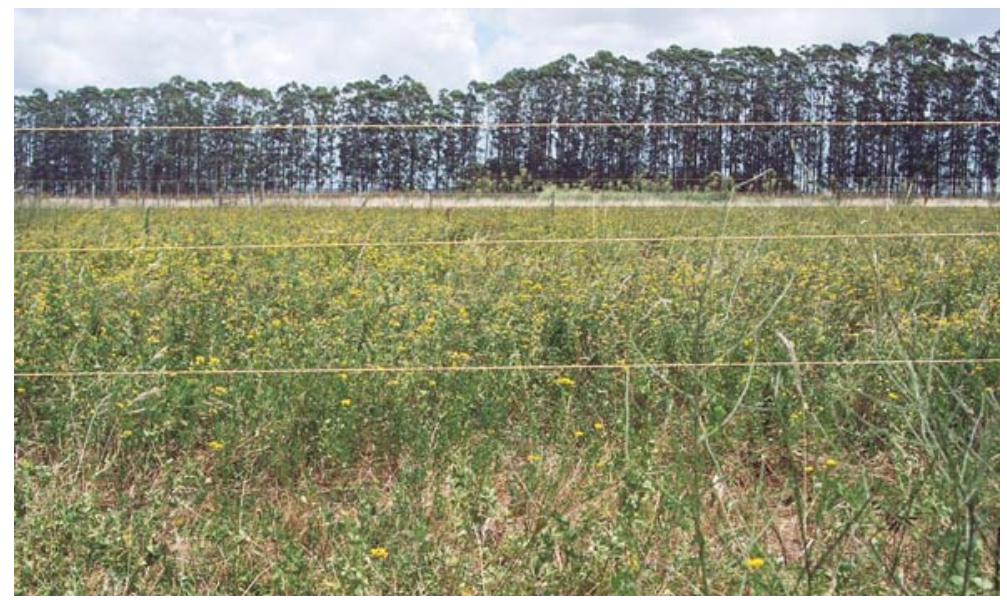

Figura 1. Pastura de Lotus corniculatus cv. INIA Draco utilizada con corderos cruza Texel durante el verano 2006/07. 


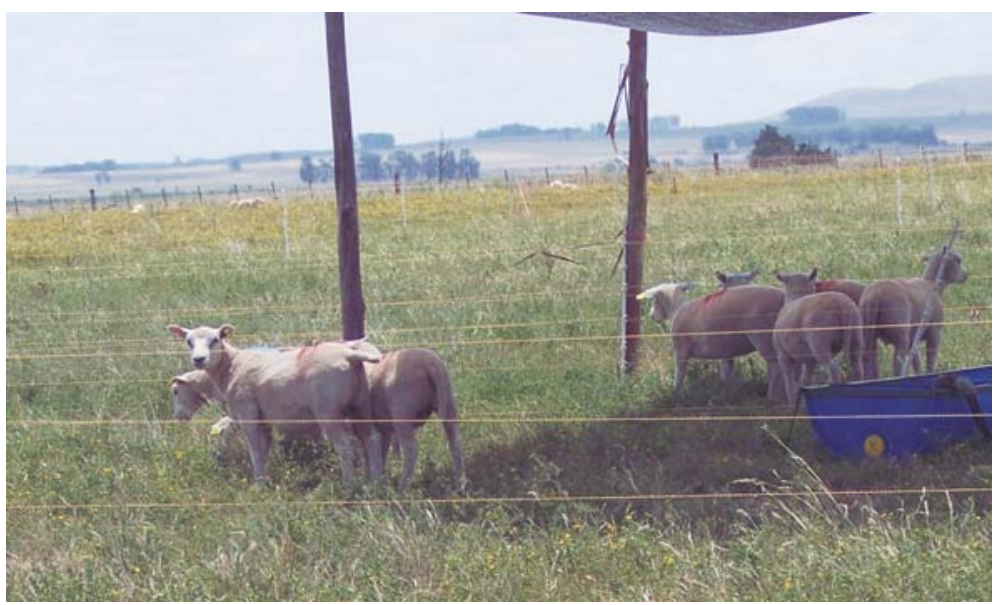

Figura 2. Corderos cruza Texel pastoreando Lotus corniculatus cv. INIA Draco en el verano 2006/07.

totalizando un promedio de 74 g/an/día y superaron significativamente a la carga de $30 \mathrm{an} /$ ha que registró pérdidas de $46 \mathrm{~g} / \mathrm{an} / \mathrm{d} i ́ \mathrm{a}$.

En el tercer ciclo, las ganancias diarias se incrementaron en todos los casos y nuevamente se detectaron diferencias estadísticas $(P<0,05)$, donde las cargas de 10 y 20 an/ha superaron a la de 30 an/ha. Para el total del período evaluado, se detectaron diferencias significativas entre las cargas $(\mathrm{P}<0,01)$, con diferencias para el promedio de 10 y 20 an/ha respecto a la de 30 an/ha de $51 \%$.

La producción de peso vivo/ha en el primer ciclo se incrementó significativamente al aumentar la carga $(P<0,01)$, mientras que en el segundo ciclo las diferencias registradas $(P<0,01)$ fueron a favor de 10 y 20 an/ha respecto a la carga de 30 an/ha. En el tercer ciclo no se detectaron diferencias entre las cargas. Para el total del período considerado se registraron diferencias significativas $(P<0,05)$ entre cargas, lográndose la máxima producción para el tratamiento de 20 an/ha con $263 \mathrm{~kg} / \mathrm{ha}$ (Cuadro 2).

\section{Calidad de canal}

Los resultados en la planta de faena reflejaron las diferencias registradas entre grupos al final del período experimental, con diferencias en los pesos vivos pre-faena $(P<0,05)$, peso canal caliente $(P<0,05)$, peso canal fría $(P<0,05)$ y $G R(P<0,05)$ (Cuadro
3). Para todas las variables mencionadas, no se diferenciaron los tratamientos de 10 y 20 an/ha entre sí, siendo el tratamiento de carga alta (30 an/ha) el que presentó significativamente valores menores.

Con respecto al rendimiento de las canales, no hubo diferencias entre los animales evaluados, independientemente del tratamiento al que pertenecían, alcanzando un rendimiento promedio de 50,7\%.

La proporción de carcasas con pesos superiores a los $16,4 \mathrm{~kg}$ fue del $100 \%$ en los tratamientos de 10 y 20 an/ha, llegando al $17 \%$ en el tratamiento de 30 an/ha.

El peso del corte de pierna sin hueso no difirió entre las cargas, estando como mínimo dentro de los estándares requeridos para cordero pesado en el $75 \%$ de los animales evaluados. El peso del corte frenched rack no fue afectado por efecto de la carga, aunque se observaron diferencias en la proporción de animales que alcanzaron el rango definido por el estándar, siendo en particular afectada la carga alta donde sólo en el $40 \%$ de los animales alcanzó los estándares definidos.

La conformación de las canales producidas mostró que el $100 \%$ de las mismas, independientemente de los tratamientos, presentaba conformación buena o superior ( $\mathrm{P}$ y S). En cuanto a la terminación, no se registraron carcasas con grado de terminación insuficiente. Por otra parte, se registró un 62,5 y un $37,5 \%$ de carcasas con exceso de 
Cuadro 3. Evaluación de calidad, tipificación y valorización de canales de corderos cruza Texel sobre Lotus corniculatus manejados con diferentes cargas durante el verano (Ayala y col., 2007).

\begin{tabular}{|c|c|c|c|c|}
\hline & \multicolumn{3}{|c|}{ Carga animal (an/ha) } & \multirow[t]{2}{*}{ Probabilidad } \\
\hline & 10 & 20 & 30 & \\
\hline \multicolumn{5}{|l|}{ Calidad de canal (pos morten) } \\
\hline Peso vivo prefaena (kg/an) ${ }^{1}$ & $39,7 \mathrm{a}$ & $38,2 \mathrm{a}$ & $32,8 \mathrm{~b}$ & * \\
\hline Peso canal caliente (kg/an) & 19,9 a & $18,4 \mathrm{a}$ & $16,0 \mathrm{~b}$ & * \\
\hline Peso canal fría (kg/an) & $19,5 \mathrm{a}$ & $17,7 \mathrm{ab}$ & $16,2 \mathrm{~b}$ & * \\
\hline GR (mm) & $17,1 \mathrm{a}$ & $13,4 a b$ & $9,2 \mathrm{~b}$ & * \\
\hline Rendimiento (\%) & 50,9 & 50,3 & 50,8 & ns \\
\hline Pierna sin hueso (kg) & 2 & 1,85 & 1,77 & ns \\
\hline Frenched rack (kg) & 0,46 & 0,44 & 0,38 & ns \\
\hline \multicolumn{5}{|l|}{ Tipificación de canales } \\
\hline \multicolumn{5}{|l|}{ Conformación } \\
\hline $\mathrm{S}$ & 50 & 12,5 & 0 & - \\
\hline $\mathrm{P}$ & 50 & 87,5 & 100 & - \\
\hline M & 0 & 0 & 0 & - \\
\hline I & 0 & 0 & 0 & - \\
\hline \multicolumn{5}{|l|}{ Terminación } \\
\hline 0 & 0 & 0 & 0 & - \\
\hline 1 & 37,5 & 62,5 & 100 & - \\
\hline 2 & 62,5 & 37,5 & 0 & 一 \\
\hline \multicolumn{5}{|l|}{ Valorización del producto } \\
\hline Peso carcasa caliente $>=16,4 \mathrm{~kg}(\%)^{2}$ & 100 & 100 & 17 & - \\
\hline Pierna sin hueso $(\%)^{3}$ & 75 & 100 & 80 & - \\
\hline Frenched rack $(\%)^{4}$ & 75 & 71 & 40 & - \\
\hline
\end{tabular}

${ }^{1} \mathrm{a}$ y $\mathrm{b}=$ medias con letras distintas en una misma fila son significativamente diferentes entre sí ( ${ }^{*} \mathrm{P}<0,05$, $* *=P<0,01$, ns $=$ diferencia estadísticamente no significativa $y-=\sin$ análisis estadístico).

${ }^{2}$ Proporción de canales que poseen un peso igual o superior a $16,4 \mathrm{~kg}$.

${ }^{3}$ Proporción de piernas que se clasifican en un rango de peso de 1,6 a 2,2 kg.

${ }^{4}$ Proporción de frenched rack que se clasifican en un rango de peso de 0,40 a 0,65 kg.

cobertura de grasa en las cargas de $10 \mathrm{y}$ 20 an/ha, respectivamente (Cuadro 3).

\section{Resultados sobre la performance de corderos pastoreando trébol rojo puro o en mezcla durante el verano}

La información disponible generada en la Unidad Experimental Palo a Pique sobre esta base forrajera es escasa y se remonta a trabajos realizados por Magallanes y Paiva
(2007). La misma refiere en primer lugar a un mejoramiento de campo de tercer año, donde se sembró trébol rojo cv. INIA Mizar puro, que fue utilizado entre el 10 y el 28 de enero (18 días) con una carga de 64 an/ha. La otra alternativa evaluada fue una mezcla de achicoria INIA Lacerta de segundo año con la inclusión en siembra directa de trébol rojo cv. INIA Mizar, utilizada con una carga de 48 an/ha entre el 28 de enero y el 4 de febrero (7 días). En ambos casos, las condiciones de déficit hídrico del verano determinaron que se debiera suspender el pastoreo 
por falta de forraje de calidad y trasladar a los animales a un verdeo de sudangrás; si bien la temperatura media del trimestre enero-febrero-marzo de 2005 no fue significativamente diferente a la registrada para la serie histórica (SH, 1972-2005), las precipitaciones resultaron $63 \%$ menos que en la SH y la evaporación del tanque A fue $22 \%$ mayor. El plan de trabajo incluyó la evaluación de los efectos de la sombra y la esquila en la performance de los corderos.

A comienzos de enero, la disponibilidad de forraje acumulada estaba situada en las 4,9 t/ha MS, con una contribución del trébol rojo de $49 \%$ y altura del forraje de $21 \mathrm{~cm}$, la relación verde/seco de la pastura fue de $0,46 / 1$ para el forraje total (Magallanes y Paiva, 2007). No se registraron diferencias entre los tratamientos al 28 de enero para el forraje remanente ni en la composición botánica del mismo. El remanente promedio fue de 1,9 t/ha MS con un 30\% de trébol rojo; aún bajo condiciones de excesiva acumulación de forraje, trébol rojo fue seleccionado, siendo la utilización general de la pastura de $61 \%$.

Las condiciones de sequía imperantes determinaron una nula capacidad de rebrote, la que asociada a la alta carga, a una merma rápida de la calidad del forraje disponible, así como a una importante pérdida de hojas, limitaron la performance animal individual, detectándose pérdidas de 19 g/an/día. Los registros no evidenciaron diferencias como consecuencia de la sombra o de la esquila en los resultados de performance individual o producción/ha.

La mezcla de trébol rojo-achicoria contaba con una disponibilidad de 3,3 t/ha MS al 28 de enero y una proporción de trébol rojo de $11 \%$, la altura de la pastura era de $27 \mathrm{~cm}$ y la relación verde/seco se situó en 0,43/1. Si bien se redujo la carga a 48 an/ha, la persistencia de la sequía afectó la pastura, permitiendo sólo un pastoreo durante 7 días.

Al finalizar el período, el forraje remanente promedio fue de 1,4 t/ha MS, registrándose una total desaparición del componente hoja tanto del trébol rojo como de la achicoria. Con estas condiciones de la pastura, las pérdidas de peso de los animales fueron de 98 g/an/día, por lo que se decidió trasladar
Ios animales a un verdeo de verano (sudangrás).

Para las condiciones del ensayo, con un verano extremadamente seco, no fue posible detectar ventajas a favor de la esquila o de la inclusión de sombra.

\section{CONCLUSIONES}

Se destaca el comportamiento del Lotus corniculatus como forrajera para las condiciones registradas durante el verano. Se logró la terminación de animales que proveen un producto de calidad en un momento particular del año, lo que avizora un importante potencial cuando se utilizan biotipos más carniceros. Los niveles de performance individual, productividad y calidad del producto generado permiten establecer que la carga de 20 an/ha fue la que permitió los mejores resultados. Sin embargo, es imprescindible ver los efectos de las prácticas de manejo en el largo plazo y en particular su repercusión en la sobrevivencia de plantas durante el invierno y en el crecimiento primaveral del lotus.

En cuanto a Trifolium pratense, las condiciones de evaluación coincidieron con eventos extremos de sequía que no permitieron explorar el potencial de esta forrajera en el verano, tanto pura como en mezcla con achicoria. Aún en ese contexto, las variables sombra y vellón no incidieron en los resultados alcanzados. Desde el punto de vista productivo, esta situación no invalida considerar a trébol rojo como una alternativa efectiva para el engorde de corderos en verano tanto puro como en mezcla con otras forrajeras.

\section{BIBLIOGRAFÍA}

AYALA, W. 2001. Defoliation management of birdsfoot trefoil (Lotus corniculatus L.). Thesis Ph.D. Massey University, New Zealand. 228p.

AYALA, W.; BERMÚDEZ, R.; BARRIOS, E. 2007. Efecto de la carga animal en la performance de corderos cruza Texel pastoreando Lotus corniculatus durante el verano. Serie de Actividades de Difusión N499. Cultivos y Forrajeras de verano. INIA Treinta y Tres. pp. 1-6. 
AYALA, W.; BEMHAJA, M.; COTRO, B.; DO CANTO, J.; GARCIA, J.; OLMOS, F.; REAL, D.; REBUFFO, M.; REYNO, R.; ROSSI, C.; SILVA, J. 2010. Catálogo de forrajeras. Instituto Nacional de Investigación Agropecuaria-INIA ISBN 97899764 382923. 131p.

DOUGLAS, G.B.; FOOTE, A.G. 1993 Growth of sheep's burnet and two dryland legumes under periodic mob-stocking with sheep. New Zealand Journal of Agricultural Research 36: 393-397.
MAGALLANES, J.; PAIVA, M. 2007. Efecto de la sombra y el vellón en la performance de corderos en el verano. Tesis de grado. Facultad de Agronomía, UDELAR. 81 p.

REBUFFO, M. 1991. Lotus en el Uruguay. 1 ${ }^{\mathrm{er}}$ Simposio Argentino del Género Lotus. INTEC II. Chascomús, Buenos Aires. pp. 43-44. 


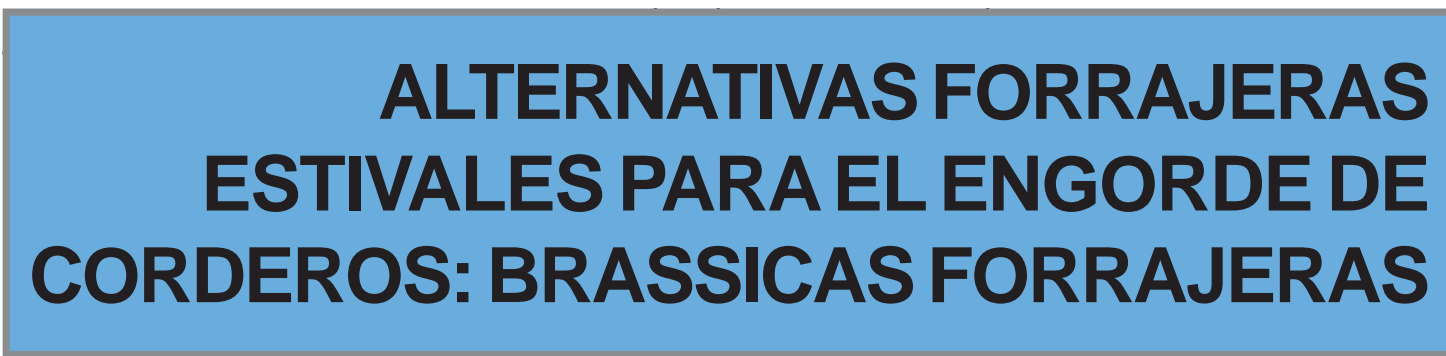

W. Ayala ${ }^{1}$

E. Barrios²

\section{RESUMEN}

Dentro de las opciones de forraje estival, las brassicas constituyen una alternativa que permite intensificar la producción ovina. Se detecta una razonable adaptación de los cultivares a las condiciones ambientales y edáficas de la región este de Uruguay. Es posible lograr performances individuales superiores a los $200 \mathrm{~g} / \mathrm{an} / \mathrm{día}$ lo que permite una terminación anticipada de los corderos, así como una alta productividad física. Como aspectos a tener en cuenta se debe mencionar la alta sensibilidad a condiciones de encharcamiento del suelo que determina pérdidas en el stand de plantas. En cuanto a su utilización por parte de los animales, se detecta una menor preferencia frente a otros forrajes en etapas tempranas de adaptación a este tipo de forrajes.

Palabras clave: ovinos, engorde, brassicas, utilización

\section{INTRODUCCIÓN}

Los nabos forrajeros son un alimento de excelente calidad para los rumiantes, con alta digestibilidad (>85\%), alta concentración de energía metabolizable (2,75-3,22 MCal/ $\mathrm{kg}$ MS) y valores moderados de proteína cruda (12-20\%; Garret et al., 2000). Pueden ser considerados como una alternativa cuando la calidad y cantidad de forraje limita el potencial productivo, para terminación de ganado o previo a la renovación de pasturas, aportando una buena oportunidad de disminuir el nivel de plagas, eliminar malezas y corregir la fertilidad del suelo (P. Kemp, com. pers).

Existe una serie de riesgos y advertencias cuando se pastorea este tipo de especies en cuanto a los tiempos de acostumbramiento, posibilidades de intoxicación por nitratos, clostridiosis, fotosensibilidad, meteorismo espumoso, oclusión por bulbos y niveles de concentración de minerales como azufre, yodo, selenio, boro y zinc entre otros (Knox et al., 2006). Resultados obtenidos en Nueva Zelanda muestran que es posible alcanzar ganancias entre 250-
300 g/an/día en corderos pastoreando nabos forrajeros (Nichol y Garret, 2001). En INIA Treinta y Tres, durante el verano 2005-2006, Ayala y col. (sin publicar) registraron ganancias de 205, 206 y 88 g/an/día en corderos pastoreando las variedades Máxima, Bonar y Pasja respectivamente, manejando cargas de 40 an/ha, durante 42 días, lo que permitió lograr producciones de carne promedio de $279 \mathrm{~kg} / \mathrm{ha}$. Estos resultados preliminares han permitido advertir el potencial forrajero y la capacidad de adaptación de esta especie a las condiciones de la región este, así como el uso potencial para determinados procesos y sistemas productivos, en particular el engorde de corderos precoces durante el verano.

El presente trabajo pretende compilar la información generada y publicada por INIA Treinta y Tres, sobre el uso de nabos forrajeros para engorde de corderos durante el verano, en ensayos donde se evalúa la adaptación de diferentes cultivares a los suelos de la región, la capacidad de carga para dichos procesos, así como validaciones a escala semi-comercial.

\footnotetext{
${ }^{1}$ Ing. Agr., PhD, Programa Nacional Pasturas y Forrajes, INIA. Director Regional INIA Treinta y Tres. ${ }^{2}$ Técnica en Sistemas Intensivos de Producción Animal, Programa Nacional Pasturas y Forrajes, INIA.
} 


\section{RESULTADOS EXPERIMENTALES}

\section{Efecto de la carga en la performance de corderos en diferentes estados del cultivo}

El siguiente ensayo se realizó con el objetivo de evaluar el efecto de la carga animal en la productividad de corderos Texel pastoreando nabos forrajeros en diferentes estadios del ciclo del cultivo (Ayalay col., 2007). El ensayo se realizó en la Unidad Experimental Palo a Pique, de INIA Treinta y Tres, sobre un argisol subeútrico de la unidad de suelos Alférez, por un período de 70 días entre el 22/01/07 y el 2/04/07. Se utilizó un potrero de 0,92 ha de nabo forrajero cv. Pasja, sembrada el 23 de noviembre de 2006 a razón de $3 \mathrm{~kg} / \mathrm{ha}$ previa aplicación de glifosato a un verdeo de raigrás.

Este cultivar se caracteriza por ser un material precoz, de alta producción, buena capacidad de rebrote permitiendo tres pastoreos o más, con mayor contenido de hojas que otras variedades y la presencia de bulbo, el cual es consumido por los animales.

La siembra se hizo en directa a $20 \mathrm{~cm}$ de distancia entre líneas, con una fertilización de base de $150 \mathrm{~kg}$ de NPK 18-46/46-0 (fosfato de amonio).

Se evaluó el efecto de la carga animal en la performance de corderos Texel nacidos en la primavera 2006, que en promedio al inicio del período pesaban $26,2 \pm 2,3 \mathrm{~kg} / \mathrm{an}$. Fueron distribuidos en cuatro cargas (24, 36, 48 y $60 \mathrm{an} / \mathrm{ha}$ ) sin repeticiones de la base forrajera en tres estados del ciclo del cultivo desde vegetativo hasta madurez avanzada (Período 1: 22/01/07-23/02/07; Período 2: 23/02/07-20/03/07; Período 3: 20/03/0702/04/07). Durante el período de evaluación el sistema de pastoreo fue continuo, en parcelas de 0,17 ha para cada tratamiento. Asimismo, los animales fueron suplementados con fardo de pradera de baja calidad ad libitum. En la pastura se tomaron determinaciones de forraje disponible, remanente post pastoreo, altura, determinación de materia seca, composición botánica y valor nutritivo. Los animales se pesaron al inicio del ensayo y luego cada 10 días. Al final de la evaluación los animales fueron faenados realizándose determinaciones de calidad de carne post mortem (peso canal caliente y fría), estimación de grasa subcutánea (GR), rendimiento, pierna sin hueso y frenched rack, así como la tipificación de las canales (conformación y terminación).

\section{Pastoreo en estado vegetativo}

El pastoreo comenzó a los 60 días de instalado el cultivo, con 3,14 t/ha MS de forraje disponible y $12,8 \%$ MS. Durante este período las ganancias diarias se situaron entre 177 y 235 g/an/día (Cuadro 1), detectándose una performance inferior para la carga baja. Este comportamiento fue en parte atribuido al consumo de una maleza presente en el cultivo, la cual fue preferida por los animales en las etapas iniciales de acostumbramiento. Dado que se manejaba la misma área de pastoreo pero diferente número de animales, la cantidad de maleza se diluyó en los tratamientos de mayor carga afectando menos la performance individual (Cuadro 1). La maleza, Solanum nigrum, es tóxica, aunque no se registran reportes a nivel nacional (F. Dutra -DILAVE, com. pers.). Esto provocó diarreas como síntomas visibles. Posteriormente, se eliminaron de forma manual las plantas de esta especie a los efectos de descartar la posible incidencia de la misma en los resultados. Si bien se les ofreció fardo como adición de fibra, los corderos no lo consumieron, tendiendo a preferir las gramíneas presentes en la pastura. El uso de altas cargas instantáneas (60 an/ha) provocó lesiones a nivel del bulbo (daños por diente y/o pisoteo), lo que sumado a que se utilizó un área donde se sembró la especie por segundo año consecutivo y probablemente existiera incidencia de enfermedades (Rhizoctonia, S. Avila, com. pers.) provocó un ataque generalizado de podredumbre de los bulbos y muerte de las plantas. El consumo de bulbos fue importante a medida que la disponibilidad de forraje disminuía, y a medida que los animales se acostumbraban a este tipo de pastura. Sin embargo puede ser discutible para estas condiciones el uso de este tipo de materiales, el cual en otras 
Cuadro 1. Resultados obtenidos en tres estadios de desarrollo del cv. Pasja de nabo forrajero bajo pastoreo con corderos Texel durante el verano (Ayala y col., 2007).

\begin{tabular}{|c|l|c|c|c|c|}
\hline \multirow{2}{*}{} & Variables & \multicolumn{4}{|c|}{ Carga animal (an/ha) } \\
\cline { 3 - 6 } & & $\mathbf{2 4}$ & $\mathbf{3 6}$ & $\mathbf{4 8}$ & $\mathbf{6 0}$ \\
\hline \multirow{4}{*}{ Período } & Disponible inicial (t/ha MS) & 2,74 & 3,23 & 4,8 & 1,78 \\
& Altura disponible (cm) & 22 & 27 & 24 & 17 \\
& Asignación de forraje (kg/an/día) & 8,7 & 6,2 & 5,7 & 3 \\
& Ganancia diaria (g/an/día) & 177 & 224 & 214 & 235 \\
& Peso vivo (kg/ha) & 136 & 258 & 329 & 451 \\
\hline \multirow{3}{*}{ Período } & Disponible inicial (t/ha MS) & 5,03 & 7,57 & 6,96 & 7,4 \\
madurez & Altura disponible (cm) & 30 & 37 & 45 & 45 \\
temprana & Asignación de forraje (kg/an/día) & 10,1 & 9,5 & 6,6 & 5,6 \\
& Ganancia diaria (g/an/día) & 248 & 205 & 212 & 176 \\
& Peso vivo (kg/ha) & 149 & 185 & 254 & 264 \\
\hline \multirow{3}{*}{ Período } & Disponible inicial (t/ha MS) & 5,5 & 7,53 & 6,58 & - \\
madurez & Altura disponible (cm) & 37 & 33 & 38 & - \\
avanzada & Asignación de forraje (kg/an/día) & 19,3 & 19,5 & 13,1 & - \\
& Ganancia diaria (g/an/día) & 96 & 92 & 12 & - \\
& Peso vivo (kg/ha) & 30 & 43 & 7 & - \\
\hline
\end{tabular}

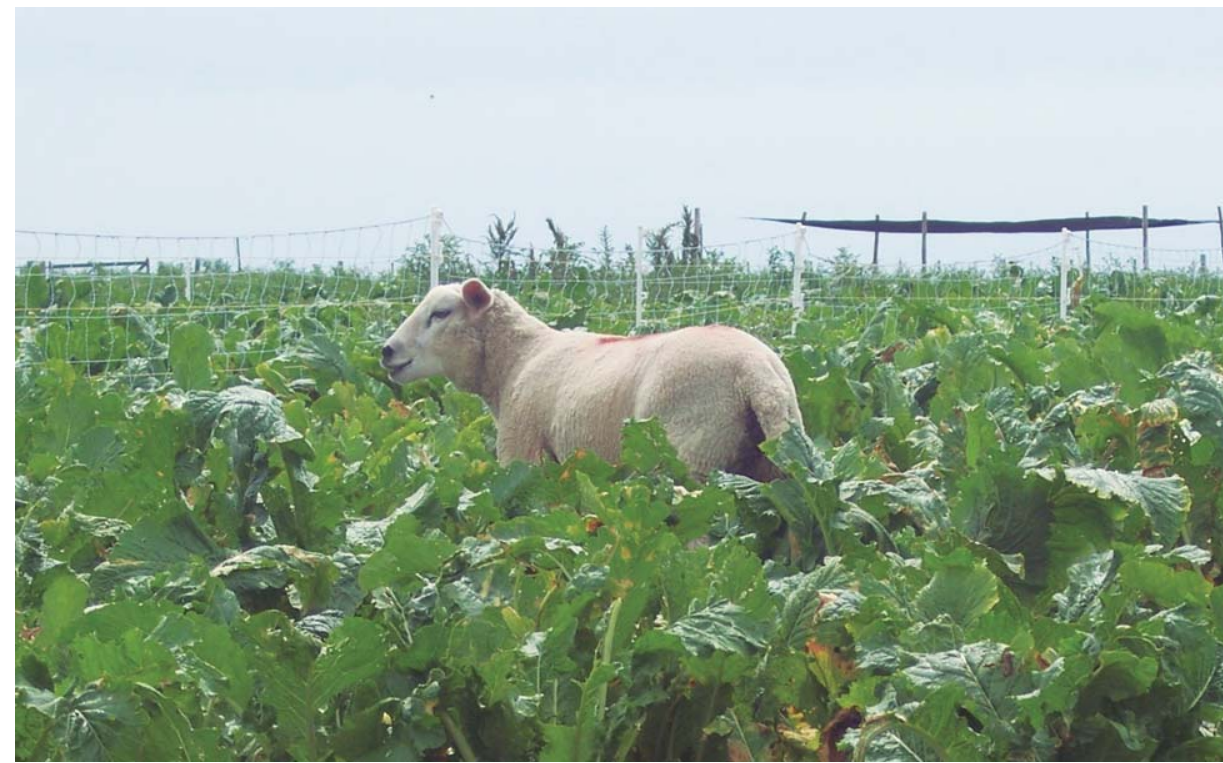

condiciones es utilizado como una reserva en períodos críticos como el invierno.

\section{Pastoreo en madurez temprana}

En este período se pastoreó por primera vez a los 92 días post siembra, habiendo acumulado al momento 6,7 t/ha MS con $11,2 \%$ de MS. Las ganancias diarias se situaron por encima de los $176 \mathrm{~g} / \mathrm{an} /$ día en todos los casos, con una tendencia a incrementarse en el tratamiento de carga más baja. 


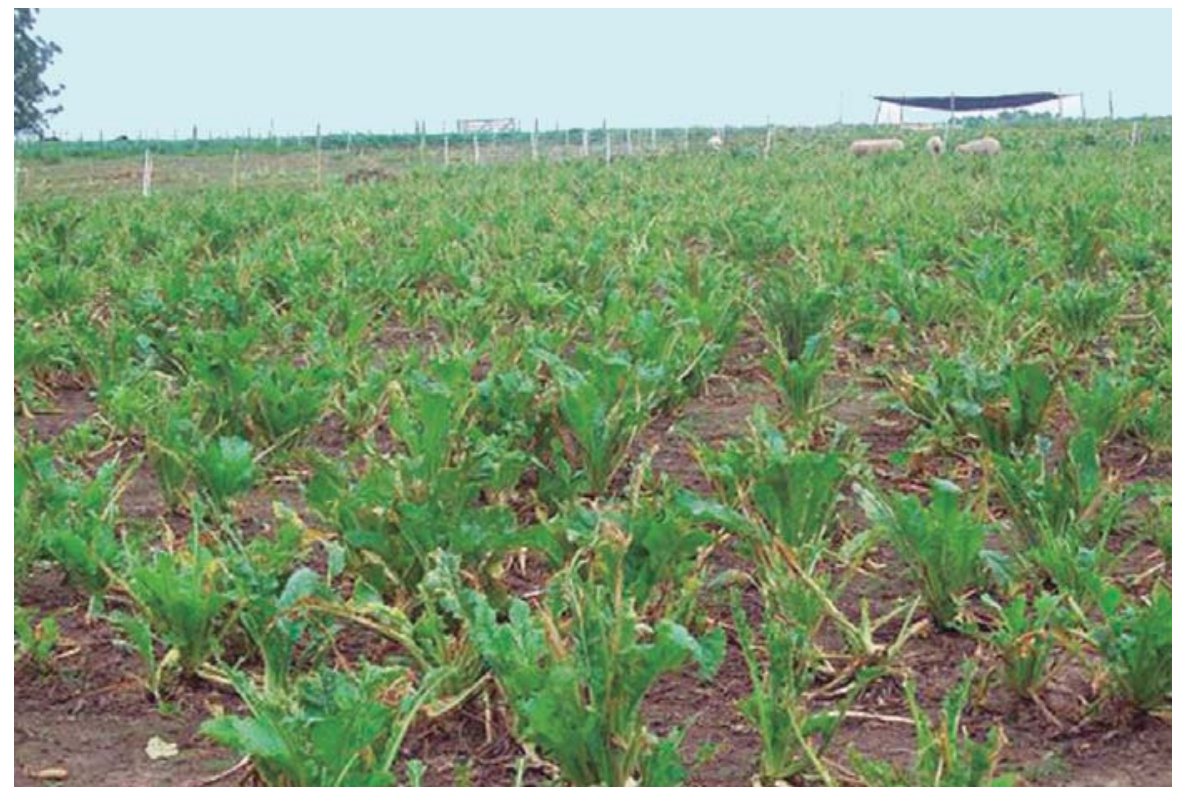

Figura 2. Cultivo de nabo forrajero cv. Pasja en estado de madurez temprana.

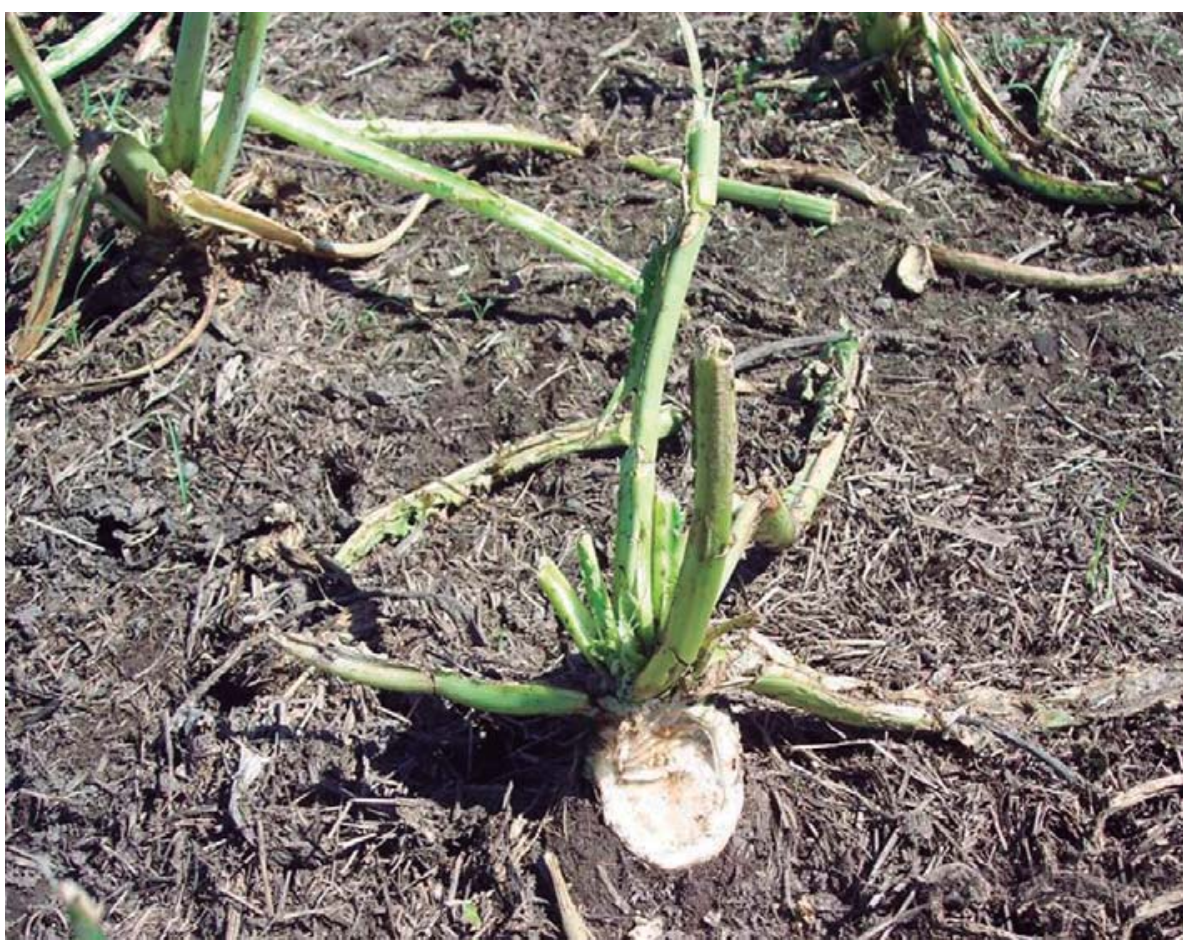

Figura 3. Planta de nabo forrajero cv. Pasja en estado de madurez avanzada.

\section{Pastoreo en madurez avanzada}

El pastoreo comenzó a los 117 días, post siembra sobre un área que había sido pastoreada anteriormente hasta el 23/02/07. La disponibilidad promedio era de 6,53 t/ha MS con y $16,1 \%$ de MS. La performance individual registrada se redujo drásticamente en comparación con los restantes períodos, evidenciando el estado de madurez del cultivo, en particular por la presencia de hojas envejecidas y secas. Debido a la incidencia de enfermedades en el stand de plantas, la evaluación del tratamiento de 60 an/ha fue descartado (Cuadro 1). 
Cuadro 2. Evaluación de calidad, tipificación y valorización de canales de corderos Texel sobre nabo forrajero Pasja manejados con diferentes cargas durante el verano (Ayala y col., 2007).

\begin{tabular}{|c|c|c|c|c|}
\hline \multirow[t]{2}{*}{ Variables } & \multicolumn{4}{|c|}{ Carga animal (an/ha) } \\
\hline & 24 & 36 & 48 & 60 \\
\hline \multicolumn{5}{|l|}{ Calidad de canal (pos mortem) } \\
\hline Peso vivo prefaena (kg/an) & $40,7 \pm 4,1$ & $40,6 \pm 4,5$ & $38,5 \pm 4,1$ & $36,3 \pm 6,5$ \\
\hline Peso canal caliente (kg/an) & $19,0 \pm 2,3$ & $19,2 \pm 2,1$ & $19,4 \pm 3,3$ & $18,6 \pm 3,4$ \\
\hline Peso canal fría (kg/an) & $18,5 \pm 1,9$ & $18,7 \pm 2,1$ & $19,1 \pm 3,3$ & $18,3 \pm 3,4$ \\
\hline $\mathrm{GR}(\mathrm{mm})$ & $8,8 \pm 3,2$ & $10,2 \pm 2,1$ & $8,6 \pm 3,7$ & $8,4 \pm 2,5$ \\
\hline Rendimiento (\%) & 46,5 & 47,3 & 47,3 & 54,6 \\
\hline Pierna sin hueso $(\mathrm{kg})$ & $2,0 \pm 0,2$ & $2,0 \pm 0,2$ & $2,0 \pm 0,3$ & $1,9 \pm 0,4$ \\
\hline Frenched rack $(\mathrm{kg})$ & $0,472 \pm 0,090$ & $0,453 \pm 0,048$ & $0,473 \pm 0,085$ & $0,454 \pm 0,081$ \\
\hline \multicolumn{5}{|l|}{ Tipificación de canales } \\
\hline \multicolumn{5}{|l|}{ Conformación } \\
\hline $\mathrm{s}$ & 25 & 33 & 37,5 & 10 \\
\hline $\mathbf{P}$ & 75 & 77 & 62,5 & 90 \\
\hline M & 0 & 0 & 0 & 0 \\
\hline I & 0 & 0 & 0 & 0 \\
\hline \multicolumn{5}{|l|}{ Terminación } \\
\hline 0 & 0 & 0 & 0 & 0 \\
\hline 1 & 100 & 83 & 75 & 100 \\
\hline 2 & 0 & 17 & 25 & 0 \\
\hline \multicolumn{5}{|l|}{ Valorización del producto } \\
\hline Peso carcasa caliente $>=16,4 \mathrm{~kg}(\%)^{1}$ & 75 & 100 & 87,5 & 80 \\
\hline Pierna sin hueso $(\%)^{2}$ & 100 & 83 & 87,5 & 70 \\
\hline Frenched rack $(\%)^{3}$ & 67 & 100 & 87,5 & 89 \\
\hline
\end{tabular}

${ }^{1}$ Proporción de canales que poseen un peso igual o superior a $16,4 \mathrm{~kg}$.

${ }^{2}$ Proporción de piernas que se clasifican en un rango de peso de 1,6 a 2,2 kg.

${ }^{3}$ Proporción de frenched rack que se clasifican en un rango de peso de 0,40 a 0,65 kg.

\section{Productividad}

Considerando toda el área experimental y el uso realizado por los animales en todo el período, se utilizó una carga de 30,4 an/ ha, logrando una producción de peso vivo de $393 \mathrm{~kg} / \mathrm{ha}$.

\section{Calidad de canal}

En el Cuadro 2 se resume la información obtenida a nivel de planta frigorífica, donde se destacan en general los buenos pesos de carcasa logrados, así como los pesos de los principales cortes evaluados (pierna sin hueso y frenched rack). El nivel de engrasamiento de este grupo de corderos Texel medido a través del GR fueron adecuados (8,410,2 mm), a diferencia de lo que sucedió para corderos cruza Texel pastoreando Lotus corniculatus, donde a niveles similares de peso de carcasa, el grado de engrasamiento fue sensiblemente mayor (Ayala y col., 2007a). La conformación de las canales muestra que el $100 \%$ de las mismas se tipificó como S o P, mientras que a nivel de terminación el $75 \%$ de las canales era como mínimo grado 1, independientemente de la carga evaluada.

\section{CONCLUSIONES}

Si bien las condiciones de humedad en el verano limitaron el establecimiento del cv. Pasja, se destaca su adaptación y productividad, lo que permitió alcanzar en un período de 70 días de pastoreo una producción de peso vivo de $393 \mathrm{~kg} / \mathrm{ha}$ utilizando 30,4 an/ ha. Fue posible alcanzar durante los estadios tempranos de desarrollo del cultivo ga- 
nancias diarias de los animales superiores a los $200 \mathrm{~g} / \mathrm{an} / \mathrm{día}$, lo cual corrobora el valor forrajero de la especie. A medida que el ciclo avanza hacia el otoño, la performance posible de lograr decae sustancialmente. No se registraron mayores trastornos en los animales por el consumo de esta especie, aún cuando la ingesta de fibra vía fardo de pradera fue insignificante. La producción lograda en términos de peso, conformación y terminación de las canales fue satisfactoria. Por tanto, estos resultados son alentadores a los efectos de considerar su inclusión en los sistemas de engorde de verano de corderos precoces, existiendo un área de mejora sustancial en la utilización de estos materiales.

\section{Evaluación de diferentes dotaciones y la utilización del campo natural como fuente de fibra adicional}

En la medida que las brassicas forrajeras ofrecen un forraje de alta digestibilidad y bajo contenido de materia seca, el mismo puede provocar en los animales desórdenes alimenticios, los cuales logran ser corregidos con la inclusión adicional de fibra (Reid et al., 1994). Estudios previos realizados muestran un potencial importante de este tipo de materiales (más de 200 g/an/día en corderos durante el verano, Ayala y col., 2007), siendo necesario ajustar su utilización y definir los materiales más apropiados, así como el grado de aceptabilidad por parte de los animales y el manejo recomendable del pastoreo.
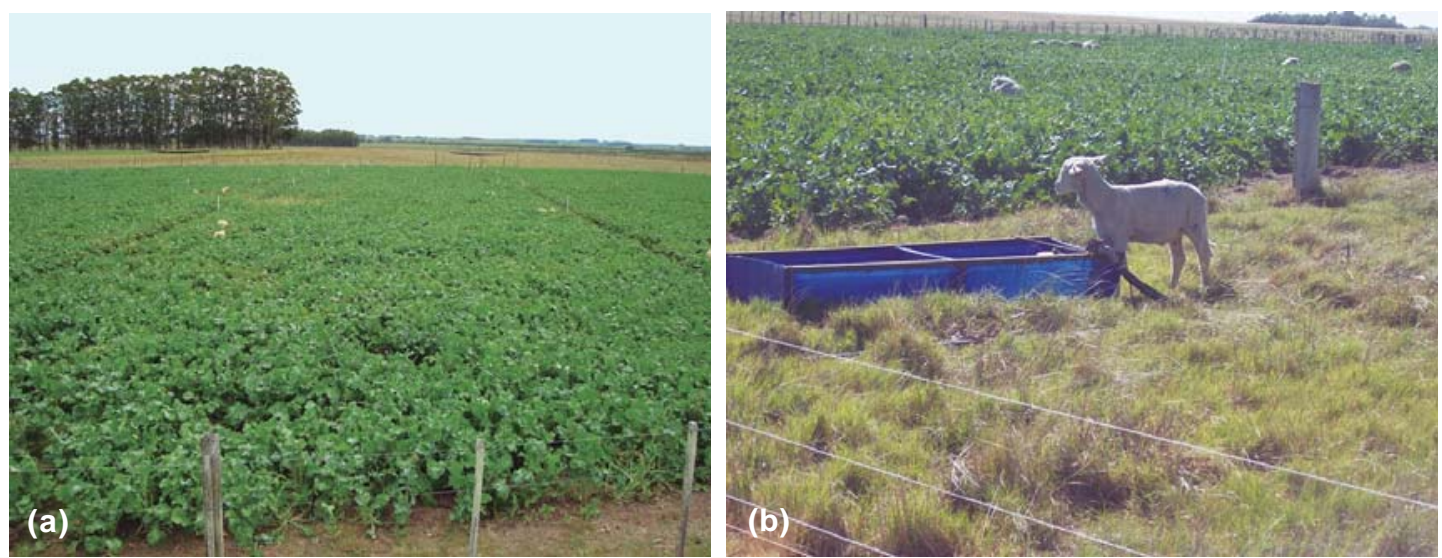

Figura 4. Vista general del ensayo y corderos pastoreando nabo forrajero cv. Goliath y campo natural, respectivamente.

Este trabajo presenta los resultados obtenidos en un estudio realizado en el verano 2009 utilizando el cv. Goliath, comparando diferentes cargas y evaluando la factibilidad de incluir un área de campo natural adyacente como fuente de fibra para los animales (Ayala y col., 2009).

El cultivar Goliath fue sembrado en la Unidad Experimental Palo a Pique, en líneas a $17 \mathrm{~cm}$ el 30 de octubre de 2008 luego de una preparación convencional. El antecesor fue un cultivo de raigrás que 45 días previos fue quemado con glifosato, el cual recibió luego dos pasadas de disquera a los efectos de preparar la cama de siembra. La densidad de siembra fue de $5 \mathrm{~kg} / \mathrm{ha}$ de semilla y la fertilización de base fue de $150 \mathrm{~kg} / \mathrm{ha}$ de 16-16-16. Dada las condiciones de sequía registradas se debieron realizar dos aplicaciones de insecticida para controlar en diferentes momentos «langostas», «pulgones» y «vaquilla», teniendo en cuenta la residualidad de los productos a los efectos del ingreso de los animales a pastorear.

Se evaluaron cuatro cargas animales (36, 48,60 y 72 an/ha), según un diseño en bloques al azar con dos repeticiones. Cada tratamiento mantuvo un número fijo de animales (7), por lo que las cargas se ajustaron según el área asignada a cada lote, compuesta por $68 \%$ del cultivo de nabo forrajero y $32 \%$ de un área de campo natural como fuente de fibra.

Se utilizaron corderos Corriedale nacidos en la primavera 2008 que presentaban un peso promedio al momento del destete, el 9 de enero de 2009 , de $21,0 \pm 1,9 \mathrm{~kg}$. Se rea- 
lizó un manejo sanitario de rutina en los animales (antihelmínticos, vacuna clostridiosis). A partir del destete se realizó un período de acostumbramiento de 21 días (P1: 9/1-30/1) en un área de nabo forrajero y con acceso a campo natural. Posteriormente, los animales continuaron pastoreando el área de campo natural previamente asignada y una nueva de nabo forrajero que no había sido pastoreada desde el momento de la siembra. Este segundo período considerado como experimental se extendió por 42 días (P2: 30/1-13/3). Entre el $13 / 3$ y el $27 / 3$ los distintos tratamientos fueron finalizando en la medida que la disponibilidad de nabo forrajero se hacía mínima, por lo cual lo producido en este período se considera como final (P3). Se realizó pastoreo continuo tanto de la parcela de campo natural como del nabo forrajero, disponiendo los animales de acceso a agua y sombra a voluntad.

Además de las determinaciones de disponibilidad de forraje y evolución de peso de los animales y a los efectos de contar con elementos para ayudar a interpretar los resultados se realizó una evaluación preliminar sobre el comportamiento de los animales durante un día (19/02), entre las 6:15 y 21:30 hs, relevando a intervalos fijos de 15 minutos en tres animales previamente identificados de cada tratamiento las siguientes variables: localización (brassica vs. campo natural) y dentro de brassica (pastoreo, rumia, descanso) y en campo natural (pastoreo, rumia, descanso y además agua y sombra dada la disposición de las mismas en el área de campo natural).

Las precipitaciones registradas evidenciaron un déficit hídrico importante en los meses de octubre y noviembre para luego registrarse precipitaciones a fines de diciembre y enero que repercutieron favorablemente en la producción de forraje (Cuadro 3). La disponibilidad de forraje (brassica más otros componentes) a los 71 días post siembra (9/1) fue de 3,60 t/ha MS, incrementándose a 5,45 t/ha MS al 30/1, 92 días post siembra.

En el Cuadro 4 se presenta la evolución de los principales parámetros (disponibilidad, altura, relación hoja/tallo y contenido de materia seca). Se observa una disminución importante en la relación hoja/tallo a partir de fines de enero que se mantiene en niveles estables hasta marzo. Las condiciones climáticas hicieron demorar el ingreso de los animales, aunque el potencial de respuesta luego de la ocurrencia de lluvias determinó un crecimiento de forraje muy elevado que afectó el manejo.

En el Cuadro 5 se presentan los resultados de disponibilidad, altura, relación verde/ seco y porcentaje de materia seca en el campo natural. Se partió de una situación de alta acumulación de forraje, con un alto contenido de materia seca, que fue disminuyendo a lo largo del período evaluado.

Un análisis parcial de la calidad del forraje muestra para el componente proteína cruda una reducción desde 19,3\% en enero has-

Cuadro 3. Precipitaciones $(\mathrm{mm})$ registradas durante el período experimental en la Unidad Experimental Palo a Pique (Julio Gorosito, Agroclimatología; Ayala y col., 2009).

\begin{tabular}{|c|c|c|c|c|c|}
\hline \multicolumn{5}{|c|}{2008} & \multicolumn{3}{c|}{2009} \\
\hline Octubre & Noviembre & Diciembre & Enero & Febrero & Marzo \\
\hline 32,1 & 4,3 & 122,8 & 109,8 & 94,5 & 187,9 \\
\hline
\end{tabular}

Cuadro 4. Parámetros de forraje del área de brassica cv. Goliath relevados desde el comienzo del período de acostumbramiento hasta el final del período experimental. (Ayala y col., 2009).

\begin{tabular}{|l|c|c|c|c|c|}
\hline Fechas & $\begin{array}{c}\text { Brassica verde } \\
\text { (t/ha MS) }\end{array}$ & $\begin{array}{c}\text { Brassica seca } \\
\text { (t/ha MS) }\end{array}$ & $\begin{array}{c}\text { Altura } \\
\text { (cm) }\end{array}$ & $\begin{array}{c}\text { Relación } \\
\text { Hoja/tallo }\end{array}$ & $\begin{array}{c}\text { Materia seca } \\
\text { (\%) }\end{array}$ \\
\hline 09-ene & 3,4 & 0,2 & 43 & 9,10 & 11,7 \\
30-ene & 4,9 & 0,5 & 41 & 0,54 & 11,8 \\
27-feb & 2,4 & 0,6 & 36 & 0,45 & 11,0 \\
13-mar & 3,5 & 0,4 & 47 & 0,52 & 16,6 \\
\hline
\end{tabular}

*Datos promedio para todos los tratamientos. 
Cuadro 5. Parámetros de forraje del área de campo natural relevados desde el comienzo del período de acostumbramiento hasta fines del período experimental. (Ayala y col.,

\begin{tabular}{|l|c|c|c|c|}
\hline Fechas & $\begin{array}{c}\text { Forraje Total } \\
\text { (t/ha MS) }\end{array}$ & $\begin{array}{c}\text { Altura } \\
\text { (cm) }\end{array}$ & $\begin{array}{c}\text { Relación } \\
\text { Verde/seco }\end{array}$ & $\begin{array}{c}\text { Materia seca } \\
\text { (\%) }\end{array}$ \\
\hline 09-ene & 4,5 & 13 & 4,5 & 69,5 \\
30-ene & 4,7 & 16 & 0,2 & 40,2 \\
27-feb & 3,9 & 15 & 3,3 & 35,9 \\
13-mar & 1,4 & 3 & 1,2 & 22,0 \\
\hline
\end{tabular}

*Datos promedio de todos los tratamientos, en ninguna fecha se registraron diferencias significativas en los parámetros evaluados.

ta $6,5 \%$ en marzo, con máximos de 23,3 y $13,4 \%$ para hoja y tallo respectivamente a comienzos de enero. El contenido de proteína cae en ambas fracciones, alcanzando valores similares $(7,9 \%)$ en marzo tanto para hoja verde como para tallo, tal lo reportado en otros trabajos.

El período de acostumbramiento fue de 21 días, registrándose pérdidas de peso en los animales en todos los tratamientos exceptuando el de carga más baja, para dicho periodo. Este comportamiento no mostró diferencias significativas entre tratamientos (Cuadro 6). Las pérdidas se situaron en un rango entre - 8 y - 24 g/an/día, con variaciones importantes entre animales. Estos experimentan un proceso de adaptación por el destete así como por la aceptación del forraje, siendo menos aceptado en comparación con las especies de campo natural.

Durante el período experimental (42 días), las ganancias de peso estuvieron entre los 151 y 168 g/an/día, sin diferencias significativas entre tratamientos. Durante el período post evaluación, las ganancias diarias declinaron sustancialmente sin mostrar diferencias entre cargas (Cuadro 6). A comienzos de la evaluación (30/1 - 13/2) las ganancias diarias fueron de $230,250,274$ y 264 g/an/ día para los tratamientos de 36, 48, 60 y 72 an/ha. Si bien se comenzó a pastorear en un momento avanzado del ciclo del cultivo, con una disponibilidad elevada y una relación hoja/tallo desfavorable la performance individual registrada confirma el valor forrajero de este tipo de materiales. A medida que se avanza en el ciclo decae la performance individual.

Por su parte, la producción de peso vivo alcanzada en el período experimental estuvo afectada significativamente por la carga animal manejada (Cuadro 6), con valores que alcanzaron su máximo en la carga de 72 an/ha.

La producción de peso vivo durante el periodo de acostumbramiento (P1) y el periodo final post acostumbramiento (P3), no mostró diferencias significativas entre tratamientos.

Cuadro 6. Ganancias diarias y producción de peso vivo de corderos pastoreando brassica cv. Goliath en tres momentos en el verano 2009 (P1: acostumbramiento entre 9/1y 30/1; P2: periodo de evaluación entre 30/1 y 13/3 y P3: período final entre el 13/3 y 27/3; Ayala y col., 2009).

\begin{tabular}{|c|c|c|c|c|c|c|}
\hline \multirow{2}{*}{$\begin{array}{l}\text { Carga } \\
\text { (an/ha) }\end{array}$} & \multicolumn{3}{|c|}{ Ganancias diarias (g/an/día) } & \multicolumn{3}{c|}{ Peso vivo (kg/ha) } \\
\cline { 2 - 7 } & P1 & P2 & P3 & P1 & P2 & P3 \\
\hline 36 & 29 & 160 & 30 & 22 & $242 \mathrm{c}$ & 15 \\
48 & -11 & 168 & 67 & -11 & $339 \mathrm{bc}$ & 22 \\
60 & -8 & 164 & 77 & -1 & $412 \mathrm{ab}$ & 32 \\
72 & -24 & 151 & 55 & -36 & $457 \mathrm{a}$ & 27 \\
Media \pm desvío & $-4 \pm 65$ & $161 \pm 35$ & $57 \pm 102$ & $-7 \pm 32$ & $362 \pm 95$ & $24 \pm 26$ \\
Probabilidad (p=) & ns & ns & ns & ns & 0,018 & ns \\
\hline
\end{tabular}

a, b, c: Medias con letras distintas dentro de la misma columna son significativamente diferentes entre sí $(P<0,05)$; ns: No significativo. 
Cuadro 7. Peso vivo de corderos Corriedale manejados a diferentes cargas en tres momentos (inicio del período de acostumbramiento (9/01), fin del período de acostumbramiento (30/01) y fin del período experimental (13/ 03). Adaptado de Ayala y col., 2009.

\begin{tabular}{|c|c|c|c|}
\hline \multirow{2}{*}{$\begin{array}{c}\text { Carga } \\
\text { (an/ha) }\end{array}$} & \multicolumn{3}{|c|}{ Peso vivo (kg/an/día) } \\
\cline { 2 - 4 } & 09-ene & 30-ene & 13-mar \\
\hline 36 & 20,9 & 21,5 & 28,2 \\
48 & 21,0 & 20,8 & 27,8 \\
60 & 21,1 & 20,7 & 27,7 \\
72 & 20,9 & 20,2 & 26,3 \\
Media \pm desvío & $21 \pm 1,9$ & $20,8 \pm 2,2$ & $27,5 \pm 2,9$ \\
Probabilidad & ns & ns & ns \\
\hline
\end{tabular}

En cuanto al peso vivo de de los animales no se detectaron diferencias a lo largo del período de evaluación (Cuadro 7). Al igual que en otras evaluaciones realizadas previamente, queda de manifiesto la importancia de los pesos de destete para lograr o no pesos finales de faena a fines de verano, resignando la terminación de los mismos para completar una fase de recría. Asimismo, lo extendido del período de acostumbramiento dificultó la posibilidad de alcanzar mejores performances finales en los animales (Figura 5).

En la Figura 5 también se observa, el momento de finalización de evaluación en los distintos tratamientos, así como la estabilización en la evolución de peso al final del ciclo, consecuencia de la baja disponibilidad, pérdida de calidad, estructura de la pastura y presencia de compuestos secundarios en el forraje.

\section{Comportamiento animal}

El sistema de pastoreo propuesto (Daniel Formoso, com. pers.), en base a fardos de buena calidad se dificulta muchas veces a nivel de predios comerciales, por lo que complementar con un área operativa de trabajo en base a una pastura natural, puede intentar resolver el problema de necesidad de fibra. Sabido es que no es recomendable que el cultivo de nabos forrajeros constituya el $100 \%$ de la dieta. La fibra es necesaria y permitiendo el libre acceso de los animales podría permitir su autorregulación.
A los efectos de entender parte de las decisiones que toma el animal frente a forrajes tan distintos en calidad y estructura, se realizó un seguimiento durante un día para registrar las principales actividades que componen la rutina de los corderos en pastoreo. Las observaciones se realizaron el día 19/02/09, cuyas características climáticas se reportan en el Cuadro 8.

En general resultó un día de alta humedad en particular en horas de la mañana, soleado hasta las primeras horas de la tarde donde comenzó a registrarse un incremento de nubosidad considerable con aumento del viento previo a la formación de tormenta hacia la noche.

En la Figura 6 se presenta la distribución de actividades en tres momentos del día, definidos en base a estudios previos que permiten separar las actividades de pastoreo en dos momentos principales del día como son temprano en la mañana y al final del día. En primer lugar y para el promedio de los tratamientos, las principales actividades registradas se dividieron a lo largo del día en 62 , 8, 4, 21 y 5\% para pastoreo, rumia, descanso, agua y sombra respectivamente. Las sesiones de pastoreo fueron estables a lo largo del día, detectándose mayor actividad en busca de agua al mediodía. La rumia fue mayor para campo natural y en particular en la mañana. Las condiciones de nubosidad en la tarde seguramente condicionaron parte del comportamiento por pastoreo después del mediodía. 


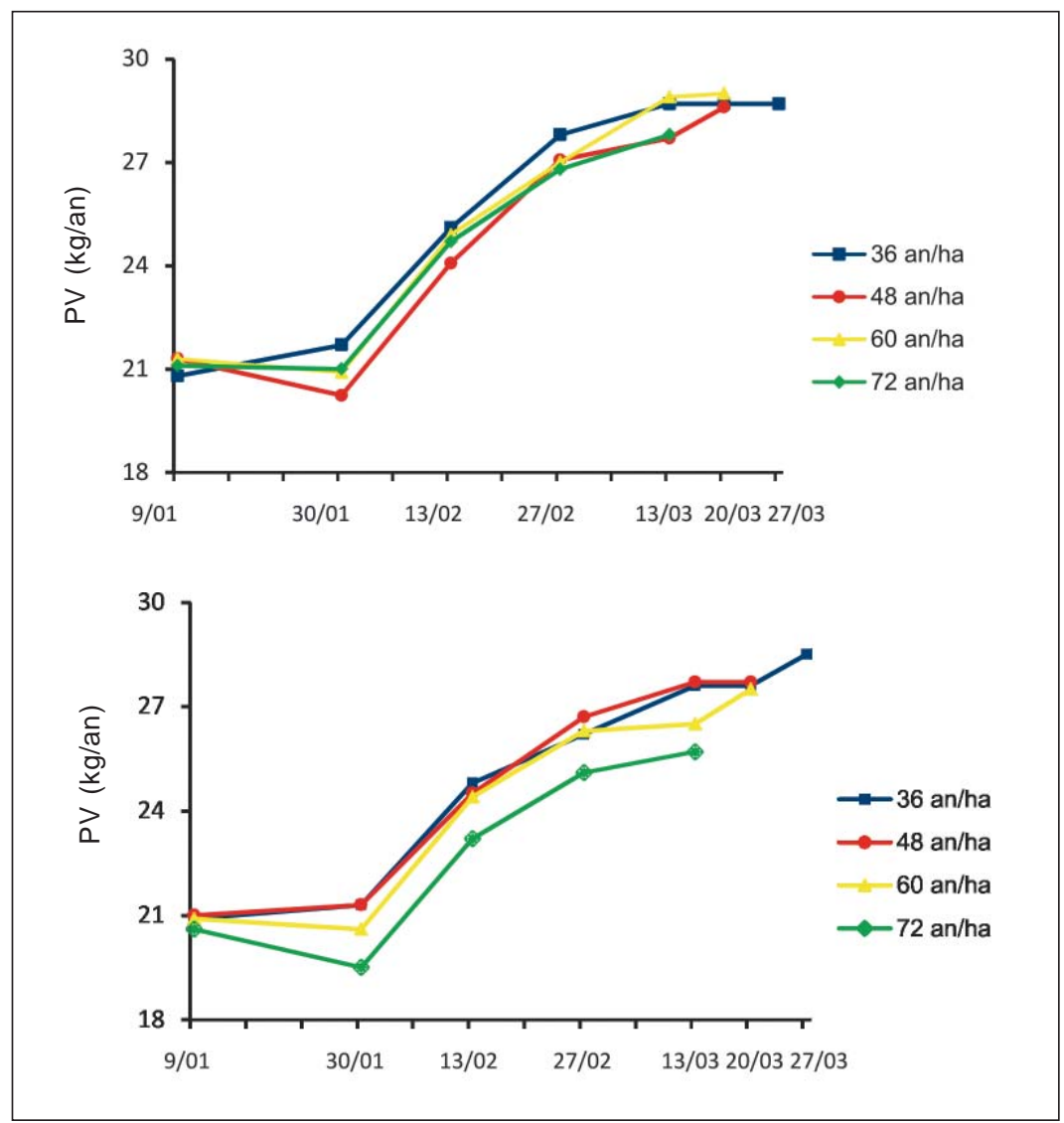

Figura 5. Evolución de peso vivo de corderos Corriedale pastoreando brassica cv. Goliath a cuatro dotaciones diferentes en el verano 2009 en cada bloque de evaluación (a. bloque 1, b. bloque 2; Ayala y col., 2009).

Cuadro 8. Parámetros climáticos del día de observación de comportamiento animal (19 febrero de 2009; Ayala y col., 2009).

\begin{tabular}{|c|c|c|c|c|}
\hline $\begin{array}{c}\text { Temperatura } \\
\text { Media }\left({ }^{\circ} \mathbf{C}\right)\end{array}$ & $\begin{array}{c}\text { Humedad } \\
\text { relativa (\%) }\end{array}$ & $\begin{array}{c}\text { Horas de } \\
\text { sol }\end{array}$ & $\begin{array}{c}\text { Velocidad del } \\
\text { viento }(\mathbf{k m} / \mathbf{h})\end{array}$ & $\begin{array}{c}\text { Evaporación TA } \\
(\mathbf{m m})\end{array}$ \\
\hline $27,1 \pm 5,1$ & 84 & 4,7 & 4,4 & 3,7 \\
\hline
\end{tabular}

Las preferencias por el cultivo de brassica se dieron en horas de la tarde, manteniéndose durante el resto del día en valores similares en las dos pasturas. En el total del tiempo destinado a pastoreo, los animales destinaron $59 \%$ al pastoreo de brassica y $41 \%$ al pastoreo de campo natural (Figura 7).

Del análisis en los distintos momentos del día, no se evidencian mayores diferencias en los patrones de comportamiento como consecuencia del factor carga. Sin duda el tiempo que los animales permanecieron sobre el campo natural muestra una mayor preferencia por esta pastura que compite con el mayor consumo que se pretende lograr del cultivo de brassica. En base a esto y en la búsqueda de una mayor utilización del cultivo, desde etapas tempranas, parecería oportuno manejar un área complementaria de campo natural menor a la considerada ( $>32 \%$ en área asignada o $28 \%$ en oferta de forraje). 


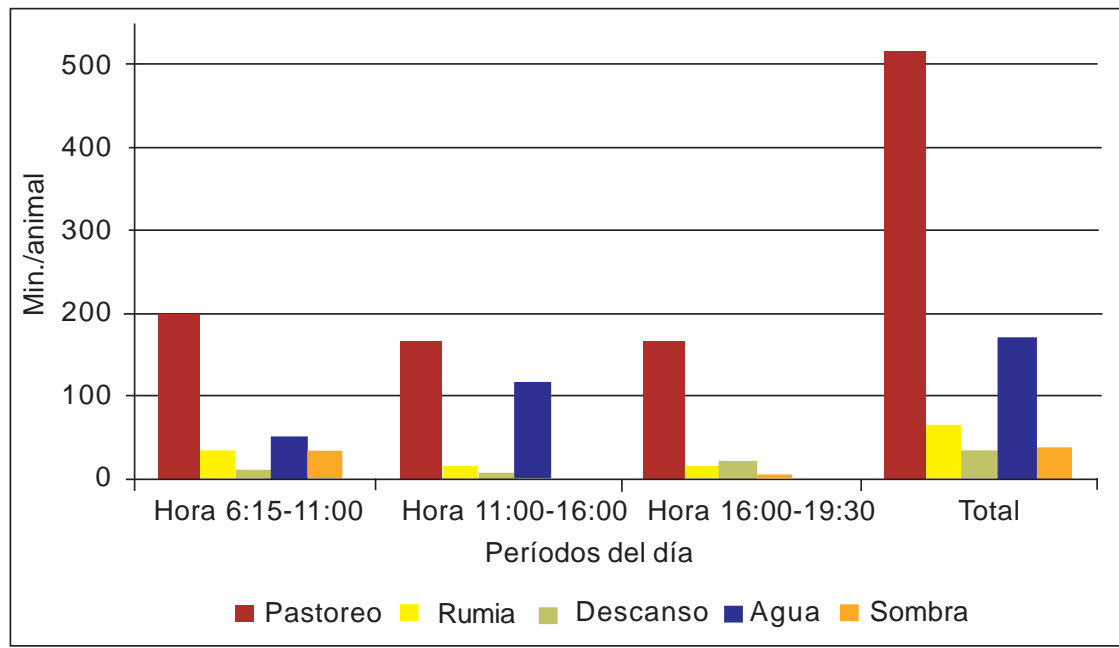

Figura 6. Principales actividades desarrolladas por los corderos expresadas en minutos/animal en tres momentos del día y para el total del tiempo de monitoreo (Ayala y col., 2009).

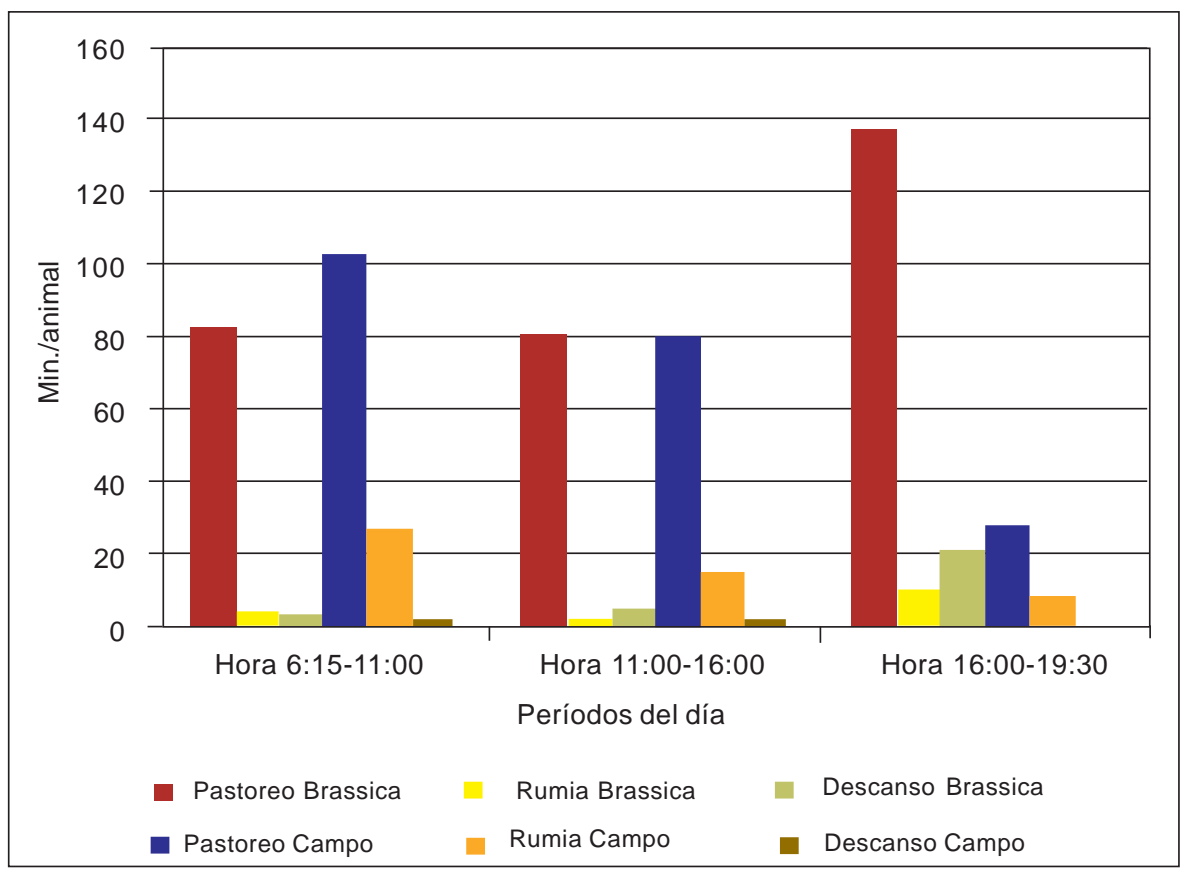

Figura 7. Distribución de las actividades de pastoreo, rumia y descanso en brassica y campo natural en tres períodos del día (Ayala y col., 2009).

\section{Observaciones}

Es posible certificar el potencial del cv. Goliath en las condiciones de suelos de lomadas, aún bajo una limitante en la disponibilidad de agua en etapas iniciales del cultivo.

El atraso en la época de entrada a pastorear determinó problemas en cuanto a la calidad del forraje particularmente en la proporción hoja/tallo.
La posibilidad de los animales de autorregular el consumo de fibra a través del agregado de un área adyacente de campo natural es factible, aunque el tiempo que destinan a pastorear el mismo determina que sea necesario reducir aún más los niveles de oferta que los manejados en el experimento.

Se lograron performances individuales ajustadas a las esperadas, aunque la termi- 

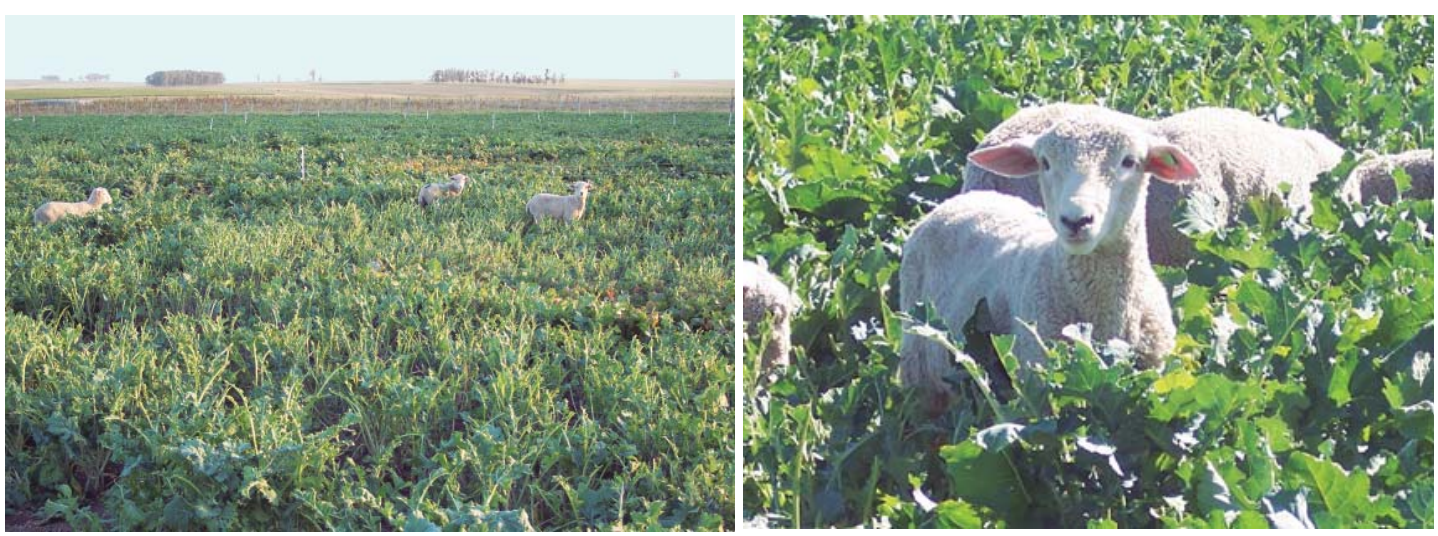

Figura 8. Corderos Corriedale pastoreando brassica forrajera cv. Goliath.

nación de los animales no fue posible por lo corto del período de evaluación y por el peso inicial de los mismos.

\section{Validaciones a escala comercial}

\section{a) Establecimiento La Aripuca, Tupambaé}

Se desarrolló un trabajo en las proximidades de Tupambaé, en el establecimiento «La Aripuca» del Sr. Alcides Lucas (Ayala y col., 2008). Se evaluaron dos variedades de nabos forrajeros Graza y Goliath (3 ha de cada uno), sembrados en directa el 5 de diciembre de 2007 a razón de 10 y 5 kg/ha de semilla respectivamente y fertilizados de base con $150 \mathrm{~kg} / \mathrm{ha}$ de fosfato de amonio (1846/46-0). Previo a la siembra se realizaron dos aplicaciones de glifosato (una en noviembre y la otra al momento de la siembra) y se acondicionó el suelo pasando una disquera.

Debido al déficit hídrico, que limitó el establecimiento y crecimiento en estadios iniciales, se optó por utilizar cada variedad en forma independiente haciendo un monitoreo en cada caso con un lote de corderos por variedad. Se ajustó la dotación en función de la disponibilidad inicial total de MS, asignando $2,5 \%$ del peso vivo por an/día, lo cual determinó dotaciones de 15 y 20 an/ha en Graza y Goliath respectivamente. El pastoreo se inició el 21 de febrero de 2008 a los 78 días post siembra. Se utilizaron animales de la raza Texel nacidos en la primavera previa (120 días de edad aproximada- mente) que al inicio del pastoreo pesaban $25,1 \pm 4,8 \mathrm{~kg} / \mathrm{an}$ para la variedad Graza y $25,2 \pm 4,8 \mathrm{~kg} / \mathrm{an}$ para Goliath. A los efectos de comparar con el manejo tradicional que se hace en el establecimiento se monitoreó un lote de corderos sobre campo natural pastoreado en forma continua a razón de 6 an/ha.

El método de pastoreo fue rotativo de tres parcelas, con tiempos de ocupación y descanso de 14 y 28 días respectivamente. Cada 14 días se realizaron las pesadas y muestreos de forraje disponible y remanente. Al inicio de la evaluación los animales se dosificaron para el control de parásitos gastrointestinales y clostridiosis. La evaluación se realizó durante 56 días entre el 21/2 y el $17 / 4$, determinando un ciclo de pastoreo y un pastoreo posterior por 12 días de toda el área sembrada.

El forraje disponible inicial al 21/2 en la variedad Graza fue 1,6 t/ha MS con un porcentaje $74 \%$ de nabo forrajero y una relación hoja/tallo de 19/1, mientras que en Goliath fue de $2,2 \mathrm{t} / \mathrm{ha}$ MS con $70 \%$ de nabo forrajero y una relación hoja/tallo de 3/1. La evolución de la disponibilidad al comienzo de los siguientes períodos se observa en la Figura 9, destacándose una proporción importante de material seco, debido a la condiciones de sequía y a la acumulación de forraje. Se evidenció una contribución de otras especies como lotus El Rincón y especialmente gramíneas nativas que actuaron como la fuente complementaria de fibra necesaria en la dieta de los corderos. 


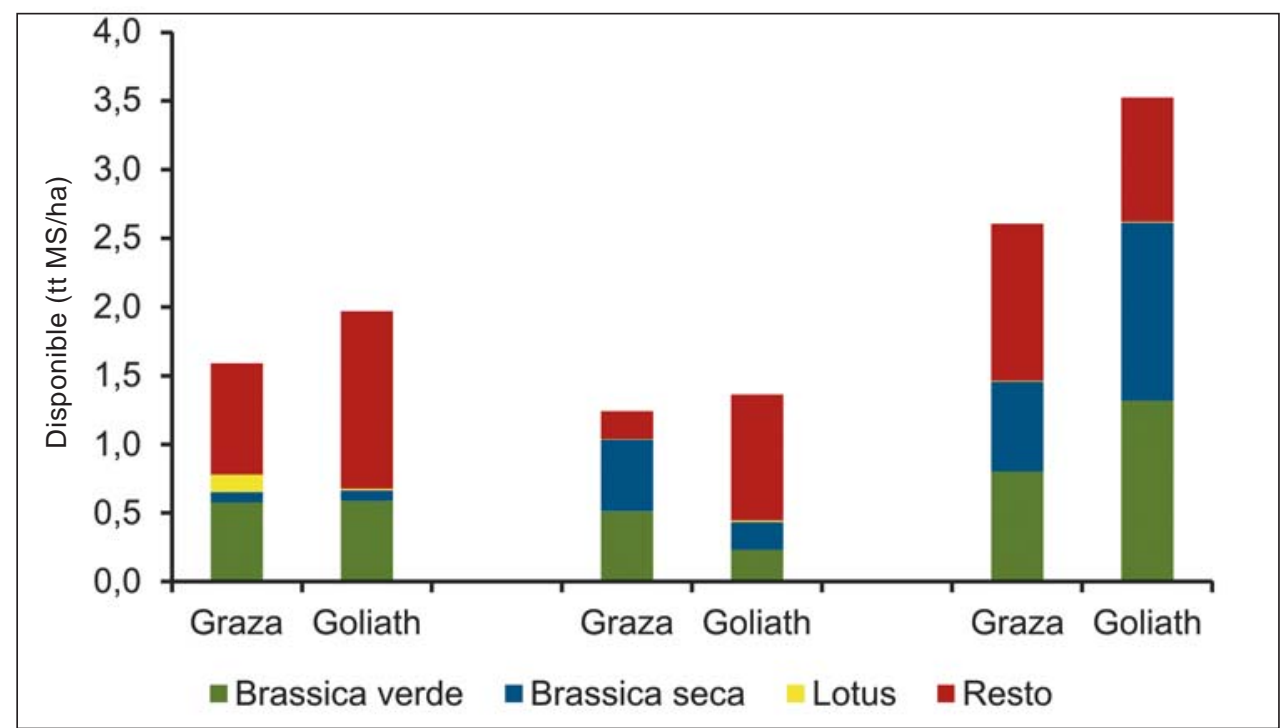

Figura 9. Evolución de la disponibilidad de forraje y composición botánica en las dos pasturas (Graza y Goliath) al comienzo del pastoreo de cada subparcela durante el primer ciclo ( $\mathrm{P} 1=21 / 2, \mathrm{P} 2=5 / 3$ y $\mathrm{P} 3=18 / 3$, Ayala y col., 2008).
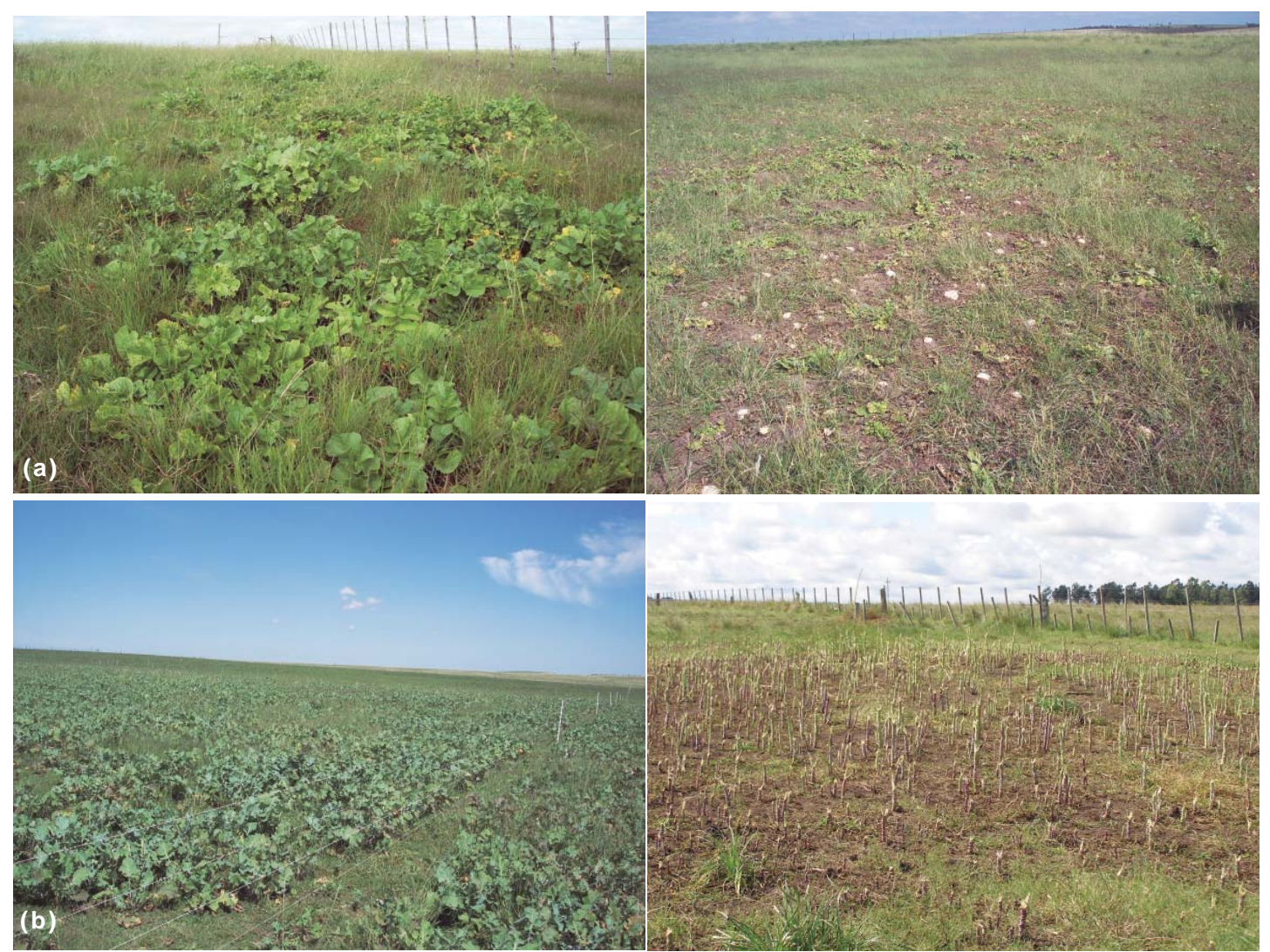

Figura 10. a) Cultivar Graza al inicio y final del ensayo respectivamente (21/2 y 17/4); b) cultivar Goliath al inicio y final del ensayo respectivamente (21/2 y $17 / 4)$. 
La calidad del forraje evaluada en dos momentos muestra altos niveles de digestibilidad in vitro de estos materiales, con una tendencia del cultivar Graza a presentar mayores valores de DMO $(85,4 \%)$ y PC $(15,4 \%)$ que Goliath. Estos parámetros decaen en sus valores a medida que transcurre el ciclo del cultivo.

El peso vivo de los animales evoluciona en forma similar en las dos variedades de nabo forrajero y en ambos casos por encima de lo que se obtiene sobre campo natural (Figura
11). En todo el período se registraron ganancias de peso de 3,8, 10,9 y 9,8 kg/an para campo natural, Graza y Goliath respectivamente.

Las ganancias diarias promedio de todo el período fueron de 68, 194 y 176 g/an/día para campo natural, Graza y Goliath respectivamente, lo cual marca un potencial productivo destacable del tipo de especies sembradas.

En la Figura 12 se observa la evolución de las ganancias diarias destacándose las diferencias a favor de Goliath durante el pas-

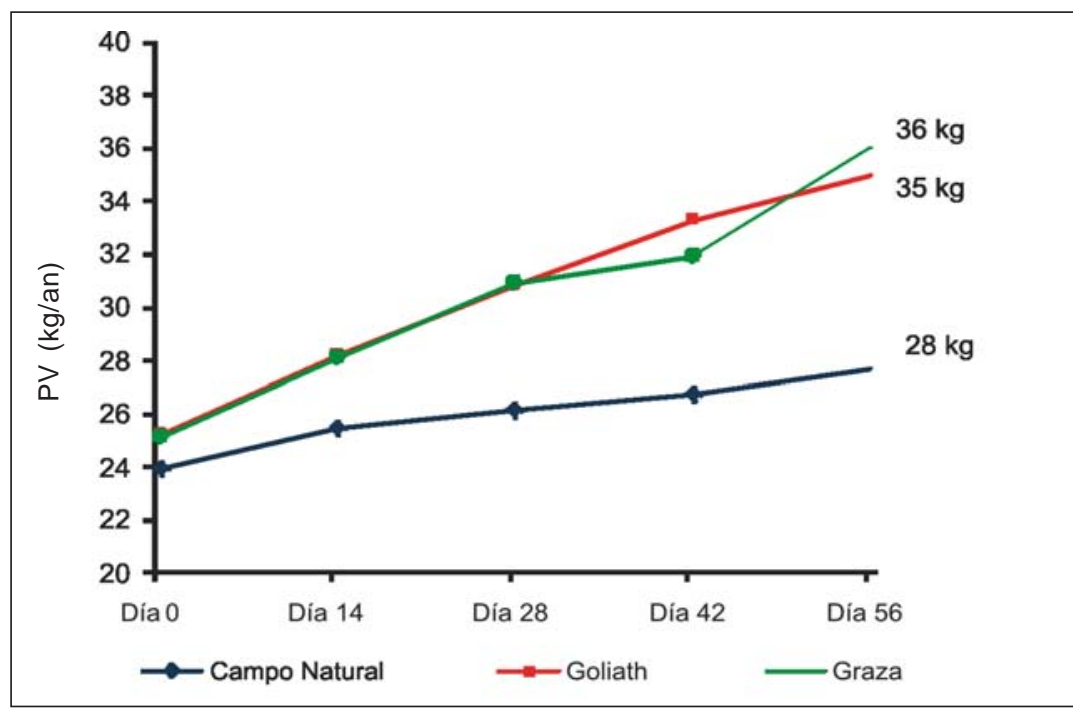

Figura 11. Evolución de peso vivo de corderos Texel pastoreando dos variedades de nabos forrajeros y un campo natural testigo con diferentes dotaciones durante el verano (Ayala y col., 2008).

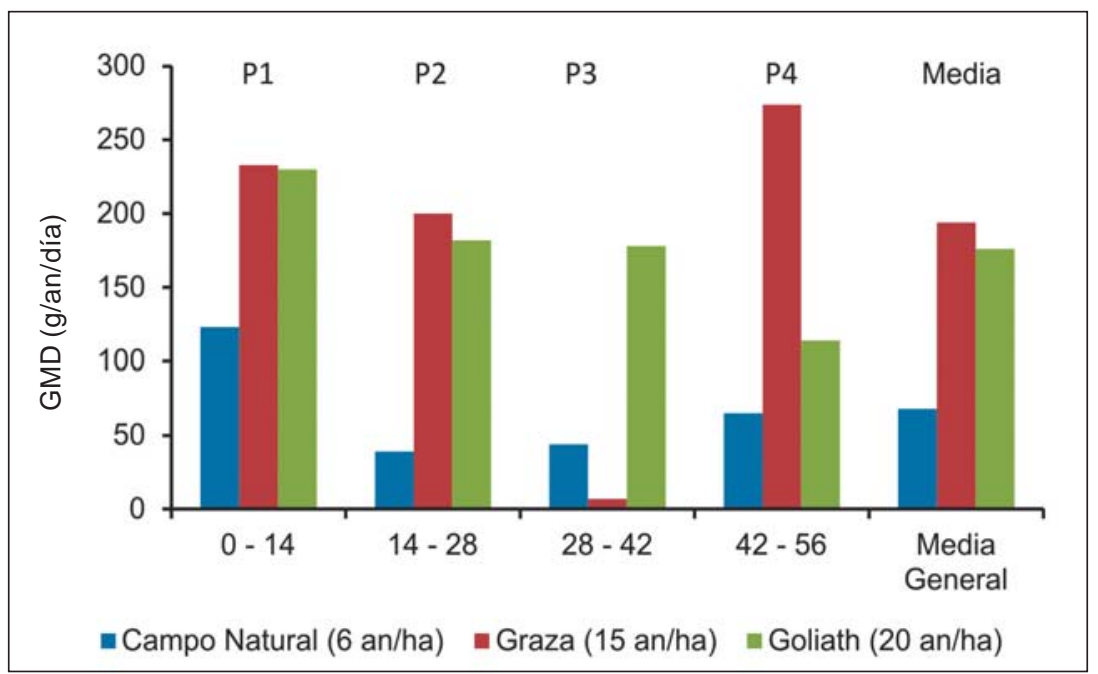

Figura 12. Evolución de las ganancias diarias de corderos Texel pastoreando dos variedades de nabos forrajeros y un campo natural testigo en diferentes momentos ( $\mathrm{P} 1=21 / 2-5 / 3, \mathrm{P} 2=5 / 3-18 / 3$, P3=18/3-3/4 y P4=3/4-17/4 y Media=21/2-17/4, Ayala y col., 2008). 
toreo de la tercer parcela (días 28-42) reflejando la mayor disponibilidad en ese momento. Para el período de pastoreo comprendido entre el día 42 y 56 , la situación se revierte a consecuencia del mayor aprovechamiento de los bulbos en la variedad Graza producto de la menor disponibilidad de forraje en forma de hojas, además del acostumbramiento, por parte de los animales, al consumo de dichos órganos subterráneos (bulbos).

La producción de peso vivo lograda en el período fue de 163, 197 y $23 \mathrm{~kg} / \mathrm{h}$ a para las variedades Graza, Goliath y campo natural respectivamente.

\section{Observaciones}

El establecimiento y producción de las variedades de brassica fue bajo a consecuencia de las condiciones climáticas registradas y posiblemente por la escasa historia de cultivo del sitio. La relativa baja fertilidad de estos suelos podría ser una limitante adicional para el comportamiento de este tipo de materiales. En términos comparativos, la variedad Goliath resultó ser mejor opción que Graza. Los materiales del tipo de Graza adaptados a condiciones de altas temperaturas y niveles de humedad moderados, con presencia de bulbo, probablemente no representan una ventaja productiva en este tipo de condiciones ambientales. Dado los niveles de performance individual alcanzados, al igual que en otros trabajos realizados, se confirma su potencial para el engorde de corderos en verano. Si bien la producción de forraje fue limitada y la producción animal alcanzada moderada, el uso estratégico de estos materiales es una alternativa a tener en cuenta en este tipo de sistemas productivos.

\section{b) Unidad Experimental Palo a Pique}

En este trabajo se utilizó la variedad de nabo forrajero Graza, que fue sembrada en 3 ha el 12 de noviembre de 2007, en directa a razón de $10 \mathrm{~kg} / \mathrm{ha}$ de semilla (Ayala y col., 2008). La fertilización se realizó con $150 \mathrm{~kg} / \mathrm{ha}$ de fosfato de amonio (18-46/46$0)$. Con anterioridad, el 27 de setiembre, se había realizado una aplicación de 3 l/ha de glifosato (Roundup full), la cual fue repetida al momento de la siembra, con igual dosis del mismo producto.

El área fue dividida en tres parcelas de 1 ha cada una, manejando el pastoreo con tiempos de ocupación y de descanso de 14 y 28 días respectivamente de un único grupo de 60 corderos (20 an/ha), los que fueron suplementados diariamente con un concentrado formulado especialmente para esta categoría animal (12\% PC) a razón de $50 \mathrm{~g} /$ an/día (base fresca) durante los primeros 28 días y posteriormente $100 \mathrm{~g} / \mathrm{an} /$ día hasta el final de la evaluación. Se utilizaron animales de la raza Corriedale nacidos en la primavera 2007 que comenzaron el período experimental (21/01/08) con un PV de 26,0 $\pm 2,4 \mathrm{~kg} /$ an. Las determinaciones (pesadas y muestreos de disponibilidad de forraje) se realizaron con intervalos de 14 días.

El sitio se ubica en un suelo de tipo planosol con escasa pendiente y poco drenaje, lo que llevó a que con las precipitaciones ocurridas a fines del mes de diciembre (170 $\mathrm{mm}$ ) se dieran condiciones de encharcamiento temporario provocando una detención del crecimiento, «amarillamiento» de hojas e incluso, muerte de plantas.

La evaluación se llevó a cabo durante 63 días, entre el 21 de enero y el 24 de marzo de 2008. La disponibilidad inicial, a los 57 días post siembra, se situó en 3,19 t/ha MS, correspondiendo en ese momento el $79 \%$ del total a brassica verde, $4 \%$ brassica seca, $16 \%$ a restos verdes, $1 \%$ a restos secos, con una presencia casi insignificante de malezas (Figura 13).

Si bien, la contribución de nabo forrajero en la pastura en los períodos sucesivos no alcanzó los 1,0 t/ha MS, correspondiendo el resto de las fracciones, principalmente a gramilla (Cynodon dactylon) y setaria (Setaria geniculata), fue la especie preferida por los animales (Figura 13). Los disponibles IV y $\checkmark$, de cada parcela muestran la poca capacidad de rebrote que tuvieron los materiales en dichos periodos. La misma fue afectada por el exceso de agua mencionado y por el consumo de los animales que ingerían no sólo hojas sino también, parte de los bulbos. 


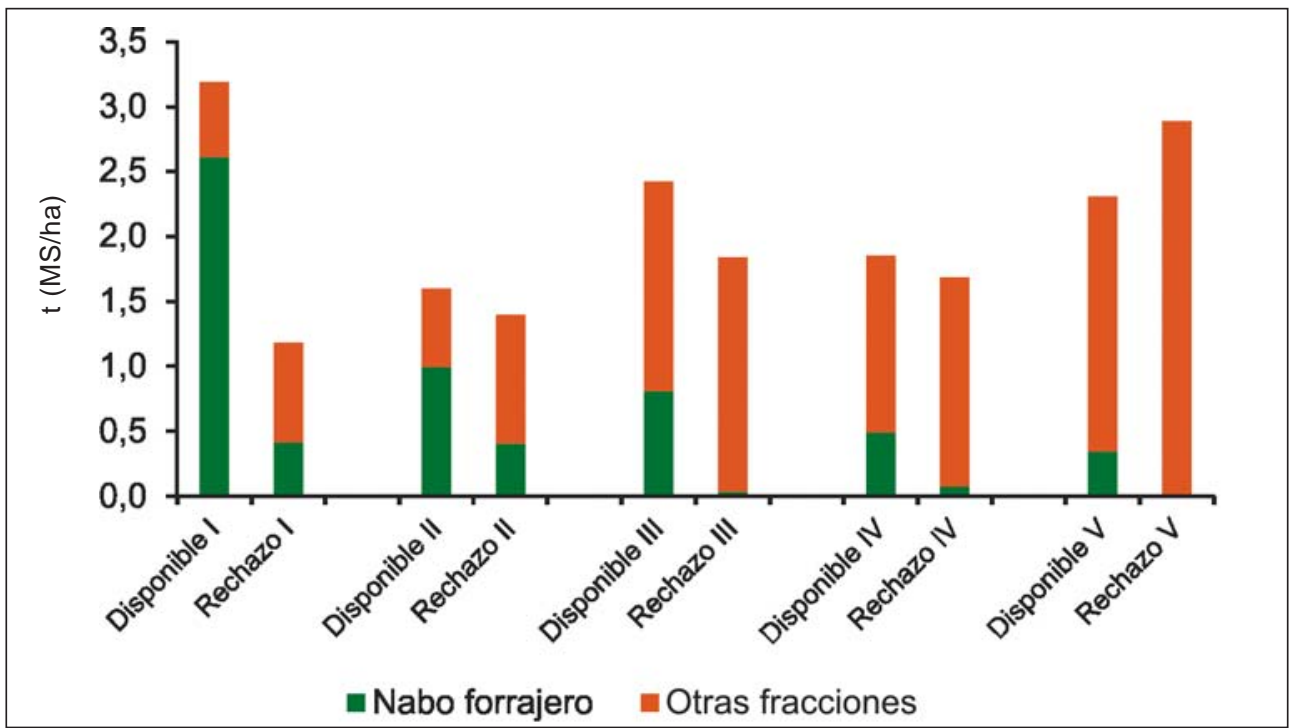

Figura 13. Evolución del forraje disponible y remanente y sus fracciones en la variedad Graza en la Unidad Experimental Palo a Pique en 5 momentos (I=21/1, II4/2, III=18/2, IV=11/3 y V=24/3, Ayala y col., 2008).
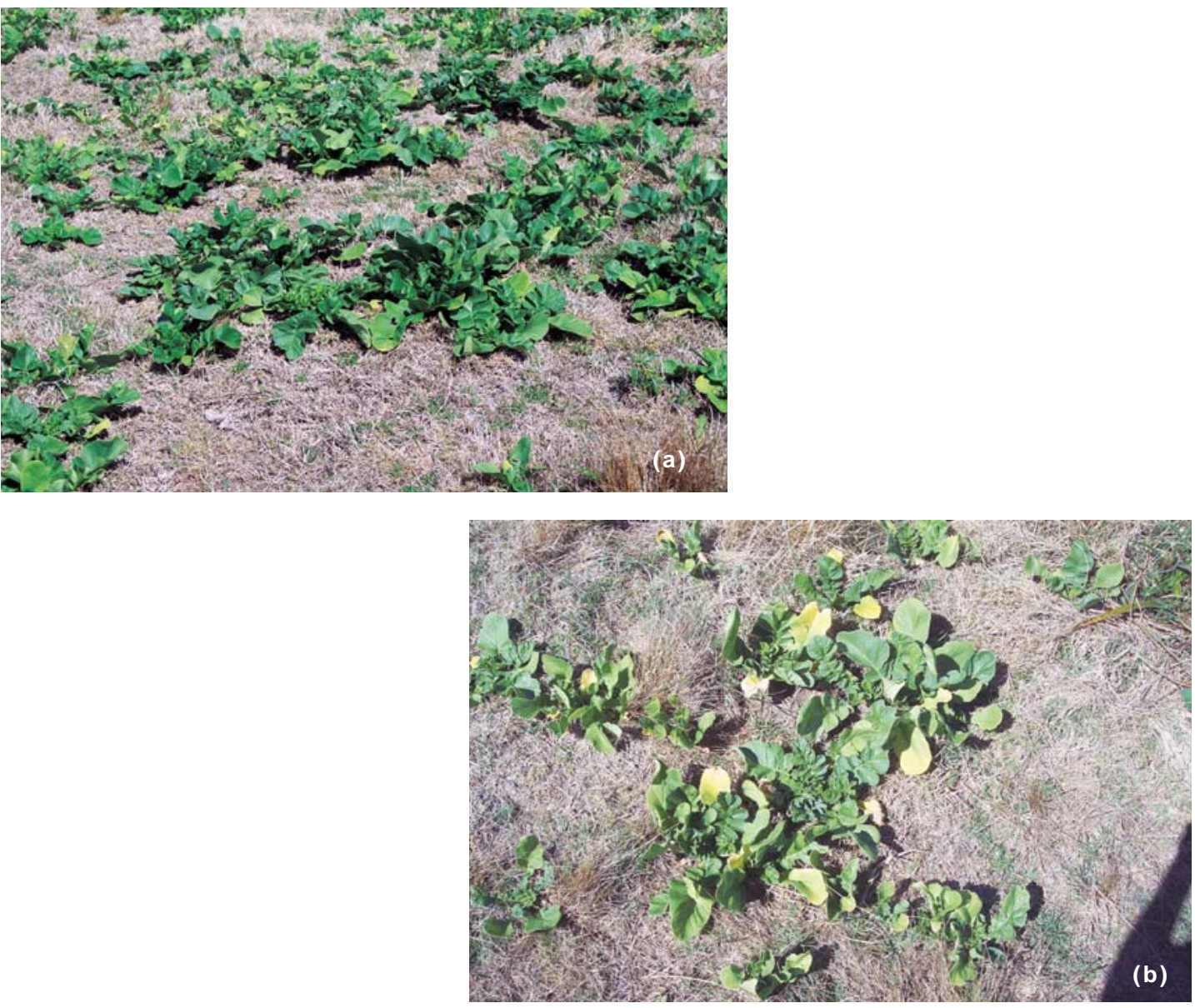

Figura 14. Cultivar Graza en primeras etapas de establecimiento (a), se comienza a evidenciar el «amarillamiento» de las hojas producto del mal drenaje del suelo (b). 


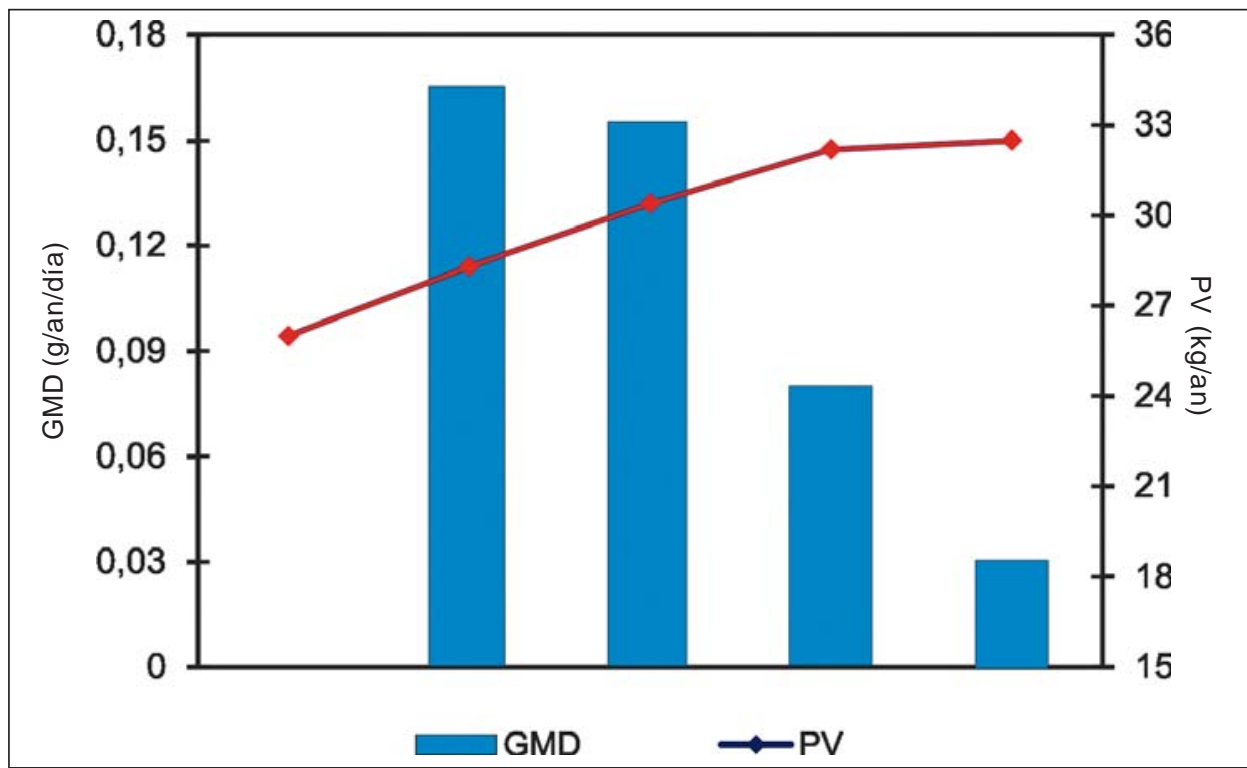

Figura 15. Evolución de peso vivo (PV) y ganancia media diaria (GMD) de corderos Corriedale pastoreando nabos forrajeros (cultivar Graza) durante el verano, (Ayala y col., 2008).

La digestibilidad del cultivo en el comienzo de los pastoreos fue de $82,3 \%$, decayendo a lo largo del ciclo del cultivo hasta $75,7 \%$, la proteína cruda por su parte se mantuvo más estable entre 10 y $11,1 \%$.

En la Figura 15 se observa la evolución de peso vivo de los animales en el período, registrándose incrementos de $6,5 \mathrm{~kg} / \mathrm{an}$. Esto determinó un peso vivo promedio del lote de $32,5 \pm 3,2 \mathrm{~kg} / \mathrm{an}$, a los 63 días de evaluación. Las ganancias diarias promedio del período se situaron en los $135 \mathrm{~g} /$ an/día, decayendo las mismas a lo largo del período experimental (Figura 15), como consecuencia de las condiciones mencionadas anteriormente.

La producción de peso vivo obtenida fue de $170 \mathrm{~kg} / \mathrm{ha}$, alcanzándose la terminación del $35 \%$ de los animales (PV>34 kg y $\mathrm{CC} \geq 3,5$ ).

\section{Observaciones}

Las condiciones climáticas y de suelo determinaron una baja producción y adaptación del cultivo. Sin embargo, la variedad Graza resultó ser un material de alta calidad apetecida por los corderos. La alta preferencia por los bulbos determina bajas tasas de rebrote o eventualmente el planteo de una estrategia de utilización diferente.

\section{CONSIDERACIONES FINALES}

Las brassicas forrajeras expresaron buena capacidad de adaptación a las condiciones de la región este, con excepciones dadas en aquellos suelos con poco drenaje donde su crecimiento y potencial se ve limitado.

Los mejores escenarios de implantación se dan en situaciones donde la cama se siembra es la adecuada, permitiendo un rápido y uniforme establecimiento del cultivo.

A nivel de la performance animal, se logró corroborar los resultados obtenidos a nivel internacional, consiguiéndose buenas ganancias medias diarias, entre 176-240 g/an/ día en periodos de madurez temprana y de entre 12-96 g/an/día en periodos de madurez avanzada donde se manifiesta un sensible descenso de las mismas.

Con respecto a la inclusión de fibra en a dieta, se evidencia la capacidad de selección de los animales, autorregulando la dieta mediante el consumo de otras especies presentes en las parcelas en los casos donde no se incluyó fardo o complemento de campo natural como fibra. 


\section{BIBLIOGRAFÍA}

AYALA, W.; BERMÚDEZ, R.; BARRIOS, E. 2007. Utilización de «Brassicas» (Nabos forrajeros) en la recría-engorde de corderos Texel durante el período estival. Resultados preliminares. Serie Actividades de Difusión N 499. Cultivos y forrajeras de verano. Resultados experimentales 2006-2007. pp. 41-45.

AYALA, W.; BERMÚDEZ, R.; BARRIOS, E. 2007a. Efecto de la carga animal en la performance de corderos cruza texel pastoreando Lotus corniculatus durante el verano. Resultados Preliminares. Serie Actividades de Difusión N 499. Cultivos y forrajeras de verano. Resultados experimentales 2006-2007. pp. 29-34.

AYALA, W.; BARRIOS, E., VELAZCO, J.; BERMÚDEZ, R. 2008. Utilización de nabos forrajeros en engorde de corderos y destete de terneros durante el verano. Resultados preliminares. Serie Actividades de difusión $N^{\circ}$ 538. Cultivos y forrajeras de verano. Resultados experimentales 2007-2008. pp. 48-59.
AYALA, W.; BARRIOS, E.; BERMÚDEZ, R.; MONTAÑO, A. 2009. Efecto de la carga animal en la performance de corderos Corriedale pastoreando nabos forrajeros durante el período estival. En: Serie de Actividades de Difusión N 591. Jornada de Divulgación de Resultados Producción Animal-Pasturas. pp. 21-28.

GARRET, B.C.; WESTWOOD, C.T.; NICHOL, W.W. 2000. Optimising Animal Production from Forage brassicas. «Capturing Value». Proceedings of the New Zealand Institute of Primary Industry. Management Conference 2000. Applied Management and Computing Division, Lincoln University. pp. 48-68.

KNOX, J.; THOMPSON, R.; CAMPBELL, S. 2006. Fodder crops. Species for profit -A guide for Tasmanian pastures and field crops$111 \mathrm{p}$.

NICHOL, W.W.; GARRET, B.C. 2001. Optimising prime lamb production on summer brassica crops. Proceedings of the World Sheep Congress 2001. 7 p.

REID, R.L.; PUOLI, J.R.; JUNG, G.A.; COXGANSER J.M.; MCCOY, A. 1994. Evaluation of brassicas in grazing systems for sheep: I. Quality of forage and animal performance. Journal of Animal Science 72: 1823-1831. 


\section{ALGUNOS FACTORES QUE INCIDEN EN LAPERFORMANCEY COMPORTAMIENTO DE CORDEROS DURANTE EL VERANO}

\section{W. Ayala ${ }^{1}$ \\ J. Magallanes ${ }^{2}$ \\ M. Paiva ${ }^{2}$}

\section{RESUMEN}

Las condiciones ambientales del verano determinan efectos en el comportamiento animal y la necesidad de adaptar el manejo de los mismos. Cuando se generan condiciones favorables de acceso a sombra y agua de buena calidad, es posible alcanzar en ciertos momentos respuestas positivas en la performance de los animales, así como una adaptación en sus patrones de comportamiento en pastoreo. La generación de condiciones adecuadas de bienestar animal condicionarán a futuro el acceso a mercados de alto valor de producto.

Palabras clave: engorde, ovinos, stress calórico, esquila, agua

\section{INTRODUCCIÓN}

La performance de corderos durante los meses de verano ha sido estudiada sobre diferentes alternativas forrajeras. Paralelamente, en varios de los trabajos realizados se han evaluado algunos factores de interés que ameritan ser tenidos en cuenta; vale la pena mencionar al consumo de agua, el stress calórico y las conductas de pastoreo de los animales. En tal sentido, se presenta un resumen de la información obtenida sobre diferentes pasturas y momentos de utilización.

\section{EFECTOS DEL ESTRÉS CALÓRICO}

La ocurrencia de altas temperaturas y elevada radiación solar contribuye a aumentar la producción de calor por parte de los rumiantes (Rovira, 2002). El animal trata de disipar el calor y mantener la temperatura corporal a través de mecanismos tales como la radiación, conducción, convección y evaporación (Collier y Beede, 1985 citados por Magallanes y Paiva, 2007).

Estos efectos se ven incrementados cuando coexisten condiciones de alta humedad y baja circulación del aire, generando en el animal reducciones en el consumo e incrementos en la producción de calor (NRC, 1981). Cuando los animales no acceden a la sombra, se genera una acumulación de calor durante el día y una etapa de disipación en la noche. Gayo (1988) señala que los ovinos, se encuentran más aislados a causa de la lana, produciendo menos calor metabólico y por ende presentando un rango más amplio de tolerancia (zona termoneutral).

Cuando el animal está expuesto al calor, la combinación de reducir el consumo de alimento e incrementar la producción de calor deriva en una menor eficiencia de los animales en crecimiento (NRC, 1981).

\footnotetext{
${ }^{1}$ Ing. Agr., PhD, Programa Nacional Pasturas y Forrajes, INIA.Director Regional INIA Treinta y Tres. ${ }^{2}$ Estudiantes de Grado Fac. Agronomía hasta 2007.
} 


\section{CONSUMO DE AGUA}

Las necesidades de agua por parte de los animales se originan como consecuencia de tres tipos de gastos (Jerrige, 1990 citado por Magallanes y Paiva, 2007):

1) excreción en heces y orina ligada a la utilización digestiva y metabólica de los alimentos; 2) fijación y evapotranspiración en las diferentes producciones; 3 ) pérdidas de vapor de agua vía pulmones y/o a través de la piel.

Los requerimientos de los ovinos varían según el metabolismo corporal, temperatura ambiente, estado de producción, tamaño, cobertura de lana, cantidad y tipo de alimento consumido, entre otros (NRDA, 1985). Es así que el consumo de agua se incrementa en dietas con alto contenido de materia seca o del tipo proteico.

Ortencio Filho et al. (2001) citados por Magallanes y Paiva (2007) encontraron una mayor frecuencia de acceso a los bebederos de animales entre las 10:00 y 14:00 hs,

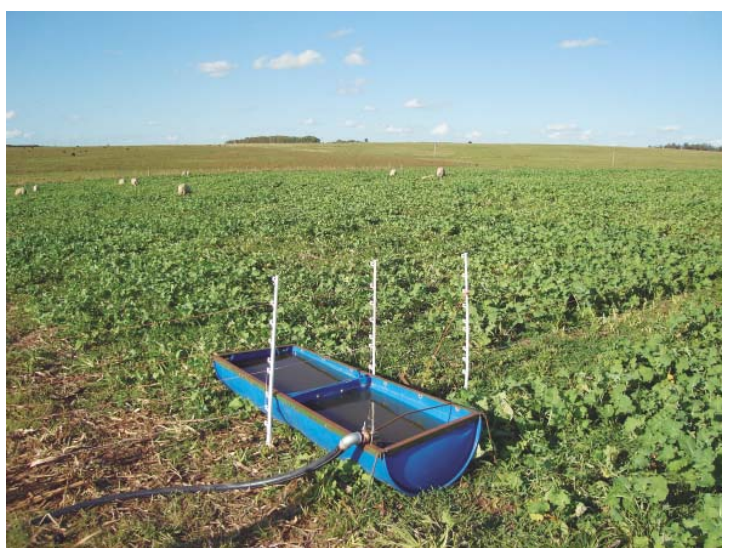

Figura 1. El acceso a agua y sombra ayuda a la reducción del estrés calórico de los animales durante el verano.

asociado a una mayor permanencia en lugares sombreados tratando de reducir el stress calórico. En ese trabajo se hace referencia también, a la reducción en el consumo de agua de animales sometidos a stress calórico en verano, consumiendo una dieta de baja calidad y con acceso a sombra.

\section{EFECTO DE LA ESQUILA}

Basándose en el conocimiento del efecto que la esquila tiene sobre la fisiología del ovino, se ha intentado utilizarlo para mejorar la performance de los ovinos en crecimiento, respuesta que ocurre cuando la temperatura desciende o sobrepasa aquellos rangos a partir de los cuales el animal debe elevar su tasa metabólica para mantener su temperatura corporal. En el caso de corderos, Speeding (1970) menciona que la zona termoneutral se encuentra entre los 20 y $30^{\circ} \mathrm{C}$, teniéndose en cuenta además la humedad y la ventilación.

En general, la esquila provoca un aumento del consumo, que capitalizado adecuadamente determina mayores ganancias de peso (Azzarini, 1983, citado por Magallanes y Paiva, 2007). Pereira y Bonino (1988), trabajando con corderos suplementados a comienzos de primavera determinaron ganancias $20,4 \%$ superiores como consecuencia de la

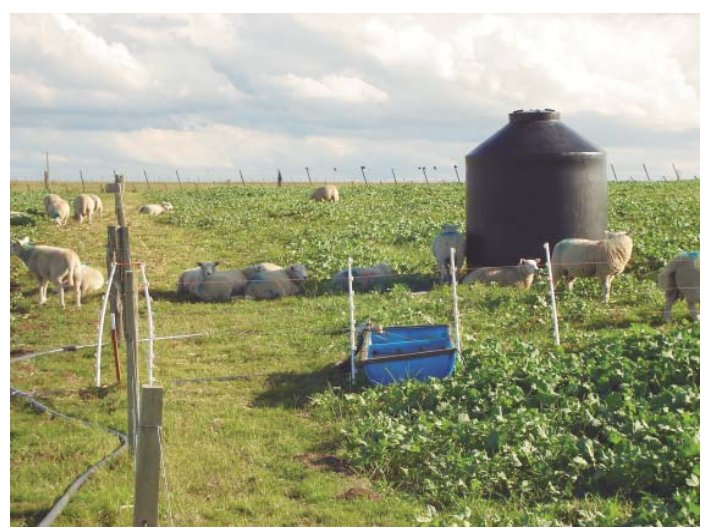



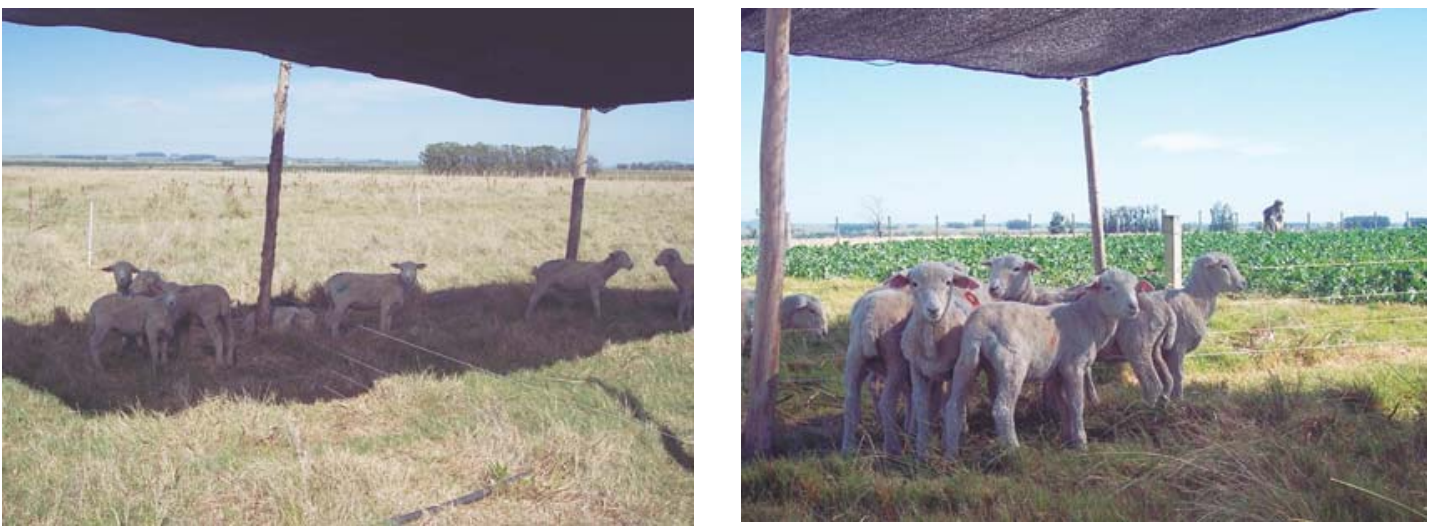

Figura 2. Animales con acceso a sombra artificial descansando en horas del mediodía.

esquila. En otros casos se ha encontrado respuesta positiva en el corto plazo (2 meses) para animales esquilados, aunque no se han detectado efectos a largo plazo en el crecimiento o en la producción de lana (Azzarini, 1983).

Por su parte, Banchero y col. (2005) no encontraron efectos en las ganancias de peso en las condiciones del verano en que fue realizado el experimento, lo que sugiere que la esquila no resulta una estrategia que modifique sustancialmente el comportamiento de los corderos.

\section{COMPORTAMIENTO DE LOS ANIMALES}

En general, los animales manifiestan un patrón de pastoreo definido a lo largo del día, estando las sesiones de pastoreo en verano fundamentalmente concentradas en las primeras y últimas horas del día, pudiendo elevarse esta condición cuando las temperaturas del día son muy altas (Hodgson, 1990; Camesasca y col., 2002, citados por Magallanes y Paiva, 2007), incrementando las actividades de descanso y rumia durante las horas de mayor temperatura.

\section{RESULTADOS}

Se ha generado en INIA Treinta y Tres información sobre el comportamiento animal y el consumo de agua en diferentes situaciones de pasturas para animales esquila- dos y sin esquilar y con o sin acceso a sombra como se describe a continuación.

\section{Consumo de agua}

Las observaciones realizadas (Cuadro 1) determinaron efectos de la sombra cuando los animales pastorearon una mezcla de achicoria-trébol rojo, registrándose un consumo de agua $23 \%$ superior en animales sin acceso a sombra. Igualmente, en otros casos se observa una tendencia a aumentar el consumo de agua en animales sin acceso a sombra, así como una propensión de aquellos animales esquilados a consumir menos agua que los sin esquilar.

Se encontró una relación entre el contenido de materia seca de la pastura y el consumo de agua, aumentando el mismo a medida que aumenta el contenido de materia seca del forraje (Figura 3).

Por su parte no se encontró una relación significativa entre la temperatura ambiente y el consumo del agua, posiblemente sea debido al estrecho rango de temperaturas evaluado $\left(20-26^{\circ} \mathrm{C}\right.$, Figura 4).

\section{Comportamiento animal}

En el Cuadro 2 se resume información general que muestra que en la mayoría de los casos estudiados no se registran diferencias en el tiempo de pastoreo de los animales como consecuencia de la presencia o no de vellón y del acceso o no a la sombra. 
Cuadro 1. Consumo de agua de corderos durante el verano en diferentes pasturas y momentos (Magallanes y Paiva, 2007).

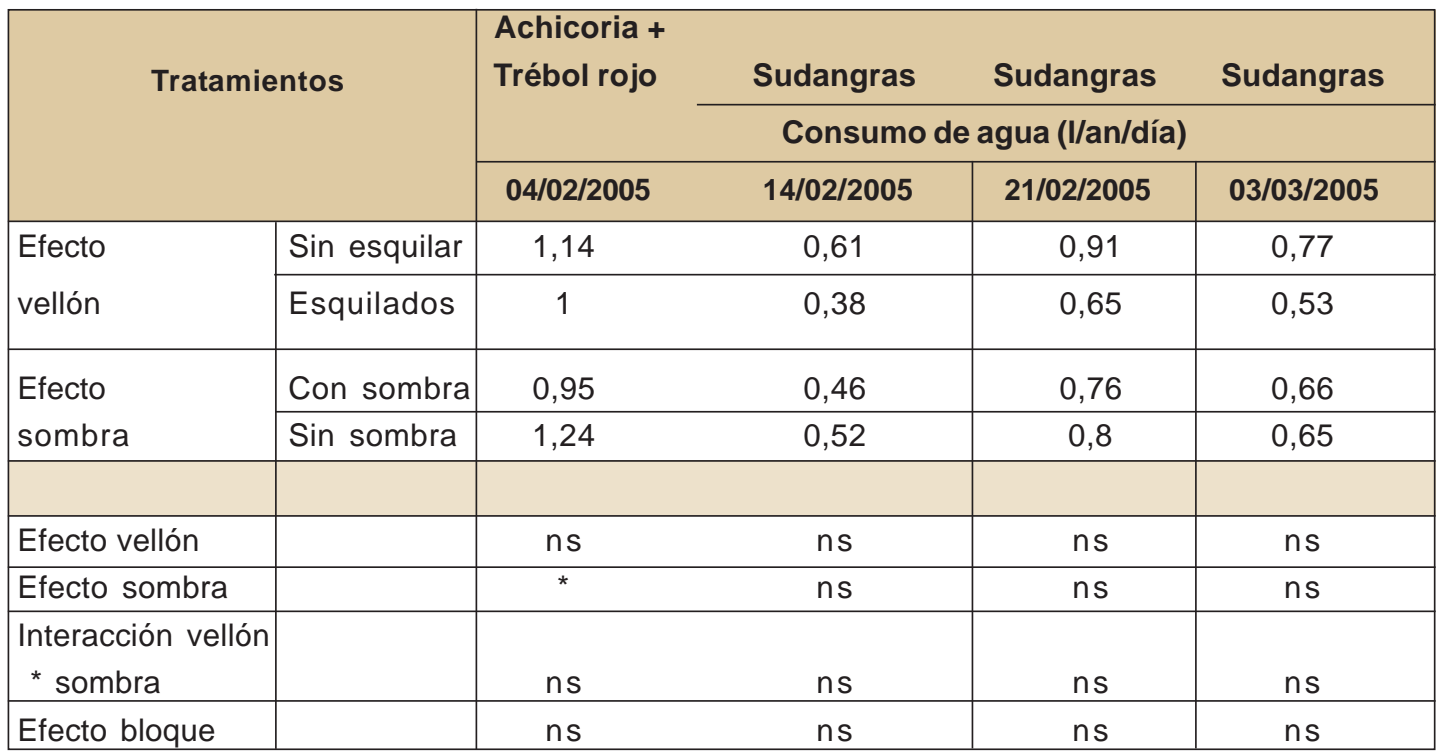

ns: diferencias estadísticas no significativas $(p>0,05)$.

Figura 3. Consumo de agua según porcentaje de materia seca de la pastura (\%MS; Magallanes y Paiva, 2007).
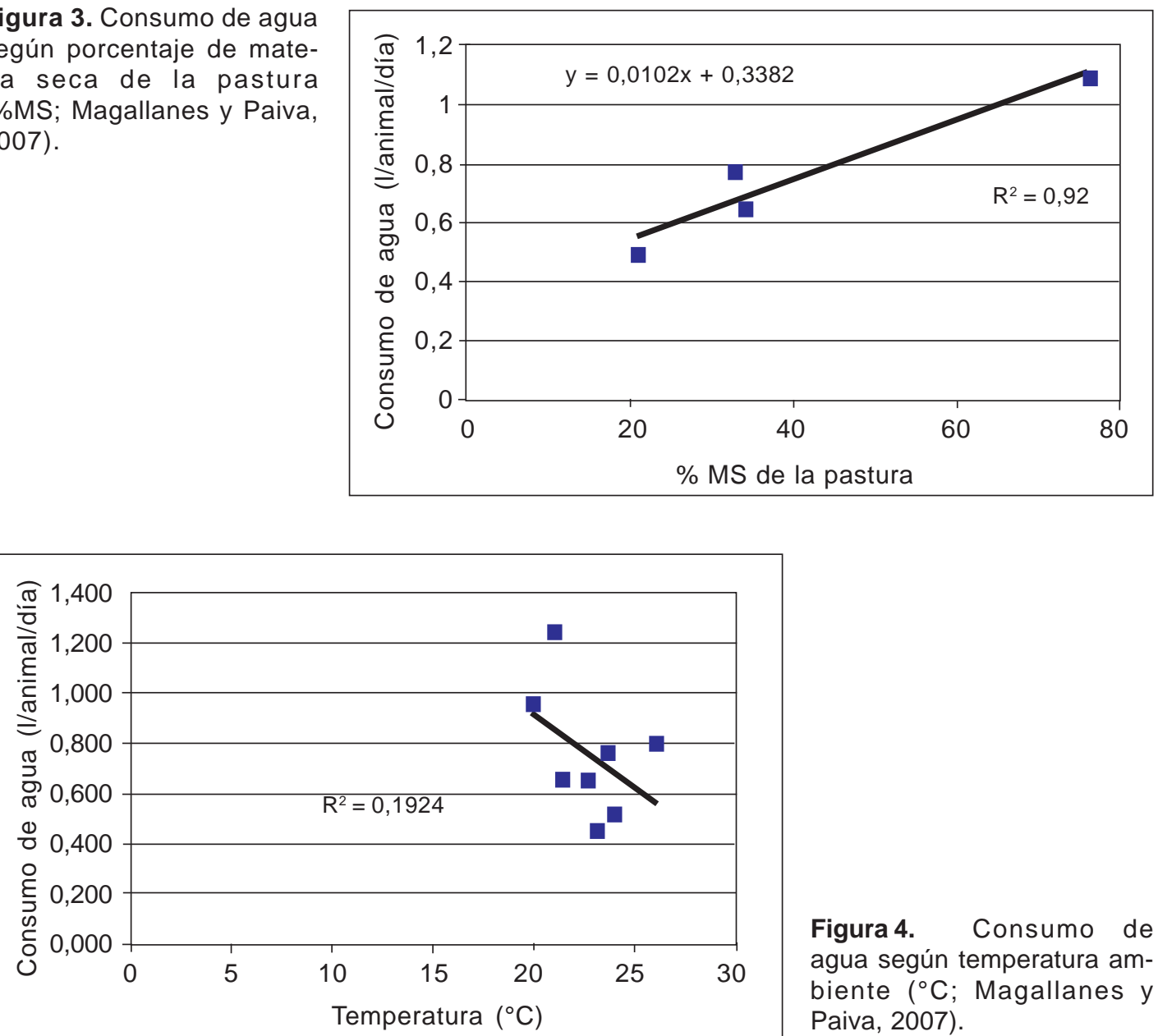

Figura 4. Consumo de agua según temperatura ambiente $\left({ }^{\circ} \mathrm{C}\right.$; Magallanes y Paiva, 2007). 
Cuadro 2. Tiempo (minutos) que los corderos destinan a cada actividad a lo largo del día en cuatro momentos y sobre diferentes pasturas (Magallanes y Paiva, 2007).

\begin{tabular}{|c|c|c|c|c|c|c|}
\hline \multirow{2}{*}{ Pastura: Trébol rojo } & \multicolumn{6}{|c|}{ Fecha 1: $21 / 01 / 2005$} \\
\hline & Pastoreo & Rumia & Descanso & Agua & Sombra & Sol \\
\hline Con Iana-con sombra & 529 & 153 & $211 \mathrm{a}$ & 7 & $344 \mathrm{a}$ & $556 \mathrm{~b}$ \\
\hline Con lana-sin sombra & 577 & 144 & $172 \mathrm{~b}$ & 7 & $0 \mathrm{~b}$ & $900 \mathrm{a}$ \\
\hline Sin lana-con sombra & 553 & 157 & $184 \mathrm{~b}$ & 6 & $324 \mathrm{a}$ & $576 \mathrm{~b}$ \\
\hline Sin lana-sin sombra & 546 & 84 & $263 \mathrm{a}$ & 7 & $0 \mathrm{~b}$ & $900 \mathrm{a}$ \\
\hline \multicolumn{7}{|l|}{ Significancia } \\
\hline Efecto vellón & ns & hs $(p=0,08)$ & ns & ns & ns & ns \\
\hline Efecto sombra & ns & ns & ns & ns & ** & $\star \star$ \\
\hline Efecto vellón*sombra & ns & ns & * & ns & ns & ns \\
\hline Efecto bloque & ns & ns & ns & ns & ns & ns \\
\hline \multicolumn{4}{|c|}{ Pastura: Achicoria + trébol rojo } & \multicolumn{3}{|c|}{ Fecha 2: 02/02/2005 } \\
\hline & Pastoreo & Rumia & Descanso & Agua & Sombra & Sol \\
\hline Con lana-con sombra & $701 \mathrm{a}$ & 123 & $76 \mathrm{~b}$ & 0 & $166 \mathrm{~b}$ & $734 \mathrm{~b}$ \\
\hline Con lana-sin sombra & $726 \mathrm{a}$ & 120 & $54 \mathrm{c}$ & 0 & $0 \mathrm{c}$ & $900 \mathrm{a}$ \\
\hline Sin lana-con sombra & $624 \mathrm{~b}$ & 103 & $170 \mathrm{a}$ & 3 & $222 \mathrm{a}$ & $678 \mathrm{c}$ \\
\hline Sin lana-sin sombra & $720 \mathrm{a}$ & 93 & $81 \mathrm{bc}$ & 6 & $0 \mathrm{c}$ & $900 \mathrm{c}$ \\
\hline \multicolumn{7}{|l|}{ Significancia } \\
\hline Efecto vellón & ** & ns & ** & $n s(p=0,06)$ & * & * \\
\hline Efecto sombra & ** & ns & ** & ns & ** & $* *$ \\
\hline Efecto vellón*sombra & ns & ns & * & ns & * & * \\
\hline Efecto bloque & ns & ns & ns & ns & ns & ns \\
\hline \multicolumn{4}{|l|}{ Pastura: Sudangras } & \multicolumn{3}{|c|}{ Fecha 3: 10/02/2005 } \\
\hline & Pastoreo & Rumia & Descanso & Agua & Sombra & Sol \\
\hline Con lana-con sombra & 643 & 146 & 111 & $0 \mathrm{~b}$ & $172 \mathrm{a}$ & $728 \mathrm{~b}$ \\
\hline Con lana-sin sombra & 648 & 126 & 109 & $17 \mathrm{a}$ & $0 \mathrm{~b}$ & $900 \mathrm{a}$ \\
\hline Sin lana-con sombra & 647 & 123 & 130 & $0 \mathrm{~b}$ & $183 \mathrm{a}$ & $717 \mathrm{~b}$ \\
\hline Sin lana-sin sombra & 627 & 177 & 96 & $0 \mathrm{~b}$ & $0 \mathrm{~b}$ & $900 \mathrm{a}$ \\
\hline \multicolumn{7}{|l|}{ Significancia } \\
\hline Efecto vellón & ns & ns & ns & ** & ns & ns \\
\hline Efecto sombra & ns & ns & ns & ** & ** & $\star *$ \\
\hline Efecto vellón*sombra & ns & ns & ns & ** & ns & ns \\
\hline Efecto bloque & ns & ns & ns & ns & ns & ns \\
\hline
\end{tabular}


Cuadro 2. Continuación

\begin{tabular}{|l|c|c|c|c|c|c|}
\hline Pastura: Sudangras & \multicolumn{9}{|c|}{ Fecha 4: 18/02/2005 } \\
\cline { 2 - 7 } & Pastoreo & Rumia & Descanso & Agua & Sombra & Sol \\
\hline Con lana-con sombra & 603 & 123 & $76 \mathrm{~b}$ & 0 & $166 \mathrm{~b}$ & $734 \mathrm{~b}$ \\
Con lana-sin sombra & 620 & 120 & $54 \mathrm{c}$ & 0 & $0 \mathrm{c}$ & $900 \mathrm{a}$ \\
Sin lana-con sombra & 642 & 103 & $170 \mathrm{a}$ & 3 & $222 \mathrm{a}$ & $678 \mathrm{c}$ \\
Sin lana-sin sombra & 581 & 93 & $81 \mathrm{bc}$ & 6 & $0 \mathrm{c}$ & $900 \mathrm{c}$ \\
\hline Significancia & & & & & \\
\hline Efecto vellón & $\mathrm{ns}$ & $\mathrm{ns}$ & $\mathrm{ns}$ & $\mathrm{ns}$ & $\mathrm{ns}$ & $\mathrm{ns}$ \\
Efecto sombra & $\mathrm{ns}$ & $\mathrm{ns}$ & $\mathrm{ns}$ & $\mathrm{ns}$ & $* *$ & ** \\
Efecto vellón*sombra & $\mathrm{ns}$ & $\mathrm{ns}$ & $\mathrm{ns}$ & $\mathrm{ns}$ & $\mathrm{ns}$ & $\mathrm{ns}$ \\
Efecto bloque & $\mathrm{ns}$ & $\mathrm{ns}$ & $\mathrm{ns}$ & $\mathrm{ns}$ & $\mathrm{ns}$ & $\mathrm{ns}$ \\
\hline
\end{tabular}

${ }^{*}=p<0,05 ;{ }^{*}=p<0,01 ;$ ns: diferencias estadísticas no significativas.

Sobre una pastura de achicoria-trébol rojo sí se detectó que los corderos sin esquilar pastoreaban $6 \%$ más de tiempo que los corderos esquilados y los corderos sin acceso a sombra lo hacían un $8 \%$ más del tiempo.

Los tiempos de rumia no fueron afectados por la presencia de vellón o el acceso a sombra.

En referencia a los tiempos de descanso, para la fecha $1(21 / 01 / 2005)$ hubo una interacción significativa vellón $x$ sombra, donde los corderos esquilados con acceso a sombra y los sin esquilar sin acceso a sombra pasaron un $25 \%$ menos de tiempo descansando que los restantes grupos.

En la fecha 2 (02/02/2005) se observó un efecto significativo de las variables vellón y sombra, donde los corderos esquilados descansaron $48 \%$ más que los sin esquilar y los corderos con acceso a sombra descansaron un $45 \%$ más de tiempo que los que no tenían acceso a la misma.

Si se analizan globalmente los datos correspondientes a las fechas evaluadas (Cuadro 3) no se registran diferencias como consecuencia del vellón para ninguna de las actividades que realizan los corderos; en cambio, se detectan diferencias significativas cuando se analiza la variable sombra. Los corderos pasan a la sombra principalmente en el período 11:00 a 16:00 horas, horario que se corresponde en general, con las mayores temperaturas del día.
En cuanto al pastoreo se observan sesiones claras en el período de la mañana y a última hora de la tarde. Los procesos de rumia y descanso se dan principalmente en los horarios de 11:00 a 16:00 hs, coincidiendo con el momento de más visitas a los bebederos.

Con respecto a los tiempos de pastoreo, se observan valores promedio de 9 hs/día, que se ajustan a los sugeridos por Hodgson (1990), quien menciona que jornadas de pastoreo por encima de 8-9 hs determinan niveles de restricción alimenticia, el animal no accede a buen forraje y pastorea más en busca de satisfacer sus requerimientos.

\section{CONCLUSIONES}

Desde el punto de vista práctico, el manejo del pastoreo en los meses de verano debería contemplar el acceso de los animales a sombra y agua de buena calidad, aún cuando algunos trabajos no muestran respuesta, es deseable generar condiciones de confort en períodos de alta temperatura. La esquila no ha mostrado resultados positivos en la performance animal, lo que lleva a pensar que sería viable realizarla previo a los embarques, de acuerdo a los protocolos establecidos. El comportamiento de animales en pastoreo y los tiempos que destinan a diferentes rutinas muestra patrones definidos, asociados principalmente a la disponibilidad 
Cuadro 3. Tiempo (minutos) que los corderos dedican a cada actividad según el horario del día en el promedio de todas las fechas (Magallanes y Paiva, 2007).

\begin{tabular}{|c|c|c|c|c|c|c|}
\hline & \multicolumn{6}{|c|}{$6: 40$ hasta $11: 00$} \\
\hline & Pastoreo & Rumia & Descanso & Agua & Sombra & Sol \\
\hline Con lana-con sombra & 213 & 31 & 15 & 1 & 15 & 245 \\
\hline Con lana-sin sombra & 218 & 24 & 17 & 1 & 11 & 249 \\
\hline Sin lana-con sombra & 214 & 27 & 18 & 1 & 26 & 234 \\
\hline Sin lana-sin sombra & 216 & 28 & 15 & 1 & 0 & 260 \\
\hline \multicolumn{7}{|l|}{ Significancia } \\
\hline Efecto vellón & ns & ns & ns & ns & ns & ns \\
\hline Efecto sombra & ns & ns & ns & ns & ** & ** \\
\hline Efecto vellón*sombra & ns & ns & ns & ns & ns & ns \\
\hline Efecto bloque & ns & ns & ns & ns & ns & ns \\
\hline \multicolumn{7}{|c|}{$11: 00$ a $16: 00$} \\
\hline & Pastoreo & Rumia & Descanso & Agua & Sombra & Sol \\
\hline Con lana-con sombra & 137 & 62 & 98 & 3 & 81 & 219 \\
\hline Con lana-sin sombra & 115 & 73 & 110 & 2 & 95 & 205 \\
\hline Sin lana-con sombra & 111 & 77 & 110 & 2 & 176 & 124 \\
\hline Sin lana-sin sombra & 141 & 58 & 98 & 3 & 0 & 300 \\
\hline \multicolumn{7}{|l|}{ Significancia } \\
\hline Efecto vellón & ns & ns & ns & ns & ns & ns \\
\hline Efecto sombra & ns & ns & ns & ns & ** & ** \\
\hline Efecto vellón*sombra & ns & ns & ns & ns & ns & ns \\
\hline Efecto bloque & ns & ns & ns & ns & ns & ns \\
\hline & \multicolumn{6}{|c|}{$16: 00$ a $21: 40$} \\
\hline & Pastoreo & Rumia & Descanso & Agua & Sombra & Sol \\
\hline Con lana-con sombra & 281 & 38 & 21 & 0 & 15 & 325 \\
\hline Con lana-sin sombra & 283 & 28 & 28 & 1 & 15 & 325 \\
\hline Sin lana-con sombra & 290 & 30 & 30 & 1 & 30 & 310 \\
\hline Sin lana-sin sombra & 274 & 36 & 19 & 0 & 0 & 340 \\
\hline \multicolumn{7}{|l|}{ Significancia } \\
\hline Efecto vellón & ns & ns & ns & ns & ns & ns \\
\hline Efecto sombra & ns & ns & ns & ns & ** & ** \\
\hline Efecto vellón*sombra & ns & ns & ns & ns & ns & ns \\
\hline Efecto bloque & ns & ns & ns & ns & ns & ns \\
\hline
\end{tabular}

**: $p<0,01 ;$ ns: diferencias estadísticas no significativas. 
de forraje y las condiciones ambientales y pueden estar condicionando los resultados productivos buscados.

\section{BIBLIOGRAFÍA}

AZZARINI, M. 1983. El efecto de la esquila en la producción ovina. Boletín Técnico Ovinos y Lanas (SUL). N ${ }^{\circ}$ 7: 41-54.

BANCHERO, G.; FERNÁNDEZ, M. F.; GANZÁBAL, A. 2005. Algunas estrategias al momento de engordar corderos pesados - Ganancias de corderos en verano, efecto de la esquila y de la utilización de sombra. Actividades de Difusión N² 426 - Día de campo Producción ovina intensiva. INIA. pp. 9-15.

GAYO, J. 1998. El ambiente y la producción animal. Revista del Plan Agropecuario. $\mathrm{N}^{\circ} 78:$ : $17-20$.

HODGSON, J. 1990. Grazing management; science into practice. New York, Longman Scientific and Technical. ISBN: 0-582-45010. $203 \mathrm{p}$.
MAGALLANES, J.; PAIVA, M. 2007. Efecto de la sombra y el vellón en la performance de corderos en el verano. Tesis de grado. Facultad de Agronomía, UDELAR. 81 p.

NATIONAL RESEARCH COUNCIL (NRC). 1981. Commision on Natural Resources. Effects of environment on nutrient requirements of domestic animals. Washington, D.C., National Academy Press. 168 p. Consultado 2 mar. 2007. Disponible en http://www.nep.edu/ catalog/4963.html

NUTRIENT REQUIREMENTS OF DOMESTIC ANIMALS (NRDA). NUTRIENT REQUIREMENTS OF SHEEP. 1985. Sixth Revised Edition. Washington, D.C., Academy Press. pp. 2-25.

PEREIRA, J.; BONINO, J. 1998. El efecto de la suplementación con concentrados y de la esquila sobre el crecimiento y engorde de corderos. Producción Ovina. 11: 27-39.

ROVIRA, P. 2002. Efecto de la sombra artificial en el engorde de novillos durante los meses de verano. Serie de Actividades de Difusión Nº 294 - INIA. pp. 79-95.

SPEDDING, C. R. W. 1970. Sheep production and grazing management. London, Baillière, Tindall and Cassell. 435 p. 


\title{
RESUMEN
}

\begin{abstract}
En Uruguay las ovejas se mantienen mayoritariamente sobre campo natural y tras la drástica caída en su número, se concentran básicamente en el Norte y sobre campos marginales. Si se agrega que se produce carne con razas no especializadas, no resulta llamativo que se demore un año en engordar un cordero, cuando se podría hacer en menos de la mitad de tiempo. Con el propósito de evaluar alternativas que permitan levantar dicha restricción, el Grupo de Ovinos y Lanas de la EEMAC (Facultad de Agronomía) ha estudiado el efecto de alimentar en forma suplementaria (grano) al cordero, sin necesidad de destetarlo tempranamente (hecho que también deprime su crecimiento) y evaluar su repercusión -posterior al destete- en encierros permanentes durante la estación más crítica: el verano. Complementariamente se han utilizado como padres razas especializadas en la producción de carne y se ha evaluado el potencial de la oveja haciéndola - también - pastorear sobre praderas que presentan más y mejor pasto. Los resultados sugieren que Uruguay podría aprovechar tres de las varias ventajas que tiene la oveja frente a la vaca: parir más de un cordero, engorde y venta con $<6$ meses de edad y mucha carne/unidad de superficie, producto no solo de los mellizos, sino del hecho que donde come 1 vaca, lo hacen 6-7 ovejas con corderos. Que las ovejas "sepan" comer grano en etapas tempranas, usar razas carniceras para maximizar el potencial de crecimiento y respuesta animal y elegir la comida contemplando el nivel de proteína, energía, minerales, calcio y bicarbonato, en forma conjunta con el medio de suministro, en encierros relativamente prolongados, ha permitido crecimientos $300 \%$ superiores a la media nacional y sin nada que envidiarle a los países líderes en producción ovina.
\end{abstract}

Palabras clave: rápido engorde, alimentación estival, cordero cruza.

\section{INTRODUCCIÓN}

En el presente artículo, abordaremos el tema contemplando cinco apartados. Conforme entendemos que las raíces son importantes y nada surge porque sí, de casualidad, sino que hay (o debería haber) un sustento detrás de cualquier plateo tecnológico, el primer apartado será sobre los antecedentes del Grupo de Ovinos de la Estación Experimental «Dr. Mario A. Cassinoni» (EEMAC) que tuve y tengo la suerte y el privilegio de liderar. En un segundo apartado, y como producto de los experimentos que hemos venido realizando desde el 2005 a la fecha, discutiremos la incidencia que diferentes factores vinculados al confinamiento tienen sobre la respuesta biológica y económica de dicha práctica. En un tercer apartado presentaremos los últimos resultados generados en el verano $2012 / 13$ en las ins- talaciones de la EEMAC. En un cuarto apartado se discutirán las posibilidades que vemos para mejorar los resultados (en particular económicos) con la implementación del feed-lot. Analizaremos en un quinto apartado el rol del confinamiento en los sistemas de producción del Uruguay, para finalizar en un sexto y último apartado con los inconvenientes que -al menos desde nuestra óptica-presentaría la implementación de esta práctica en emprendimientos significativos en el país.

\section{ANTECEDENTES DEL GRUPO DE OVINOS DE LA EEMAC}

Hace ya 17 años que comenzamos a planificar el programa de cruzamientos (Bianchi y col.,1997) que funciona en la EEMAC y que fuera validado y difundido comercialmente 
(Garibotto y col., 2003) como un cordero similar al neoncelandés y por cierto muy distinto al cordero pesado tradicional originado por el SUL (Azzarini y col., 1996): el primero en base a cruzamientos terminales con razas laneras, más pesado, mejor conformado y terminado y con una edad inferior a la mitad del cordero lanero comercializado a los 10 -12 meses de edad promedio. En dicho programa de investigación también pensamos en la otra característica primordial en cualquier sistema de producción de carne como es la reproducción y también lo hicimos desde una óptica genética. Sendos proyectos financiados por INIA con la raza Milchschaf primero (Bianchi y col., 2001) y más recientemente con la Finnsheep (Bianchi, 2013) después, llevamos adelante durante más de 6 años con el propósito de generar alternativas para aumentar la prolificidad, principal componente de la tasa de procreo.

En forma paralela desarrollamos una batería de experimentos durante la primavera y verano (uso de grano sobre pastizal nativo a corderos destetados Rivero y col., 2013a; y creep-feeding; Garibotto y col.,2009; Rivero y col., 2013b; 2013c) y durante el verano (pastoreo restringido y nocturno sobre pasturas sembradas, cultivo de soja, y brassicas; Garibotto y Bianchi, 2007), con el propósito de darle sustento a la propuesta tecnológica del cordero pesado cruza, pero precoz, con más carne, menos grasa y mayor proporción de cortes de alto valor. Bianchi y Garibotto (2008), publicaron una revisión que contempla todos los trabajos hechos por la Facultad de Agronomía de confinamiento de corderos.

Hoy estamos en condiciones de señalar que generamos analíticamente y validamos comercialmente un producto diferente y de mucha mejor calidad (Bianchi, 2010) a cualquier otra opción desarrollada en el país. Es precisamente con este cordero que el Uruguay va a poder acceder si se lo propone (y si lo dejan) a los mercados más exigentes del mundo. Es también sobre la base de este producto que hemos trabajado en confinamiento.

\section{FACTORES QUE EXPLICAN LA RESPUESTA AL FEED-LOT}

En términos generales estos factores se han dividido en aquellos relacionados con el alimento, con el animal y con el manejo. Garibotto y Bianchi (2006), analizaron la incidencia de estos factores en la respuesta biológica y económica al feed lot, por ello y por razones de espacio seremos concisos en este punto.

Sin dudas la alimentación es el factor más importante, en particular por el papel relevante que tiene en los costos de dicha práctica, explicando, sin considerar la reposición, más del $80 \%$ de los costos totales. Dentro de ésta y por la categoría que -en generalse decide confinar, la proteína resulta el nutriente esencial. Trabajos realizados en el país (Piaggio y col., 2013) reportan respuesta animal lineal hasta el $18 \%$ de PC en la dieta; siendo la pasta de soja el alimento más comúnmente utilizado. Sin dudas, la energía también es importante y en general es cubierta con granos de cereales (maíz, sorgo, avena). La relación concentrado: voluminoso, cuando no se recurre a dieta totalmente mezclada, no constituye tampoco un tema menor, encontrándose los mejores resultados con relaciones cercanas a 90:10, cuando el acostumbramiento es correcto. Existen diferencias en el tipo de voluminoso, siendo lo mejor el fardo de alfalfa picado, aunque también hay experiencias locales con fardos de moha, ensilaje de raigrás o aun silo de maíz o sorgo. Además del concentrado y la fibra, hay otros elementos que es importante considerar. En este sentido la presencia de micro-elementos, complejo vitamínico (que también se puede inyectar al animal al inicio del encierro), carbonato de calcio (para evitar problemas de urolitiasis) y bicarbonato $u$ otros aditivos que prevengan la ocurrencia de trastornos metabólicos (acidosis) resultan claves. Ni hablar del agua en cantidad y sobre todo calidad: un cordero consumiendo en el entorno del $4,5 \%$ de su peso vivo de materia seca y en verano, puede lle- 
gar a tomar fácil 6-8 litros diarios de agua y si no la tiene, sencillamente reducirá su consumo y con él su desempeño.

Dentro de los factores vinculados al animal, hemos trabajado en el sexo, el peso al inicio del encierro y el biotipo y en forma muy resumida podemos aseverar que el desempeño es mejor en los machos encerrados con un rango de peso de: $20-28 \mathrm{~kg}$ y cruza carnicero frente a las hembras (los castrados tienen un comportamiento intermedio), con pesos $\geq 30 \mathrm{~kg}$ y de razas laneras o mal Ilamadas doble-propósito. Además de consumir más, los corderos más livianos y cruza son más eficientes en convertir el alimento en carne.

Obviamente que existen diferencias también dentro de las razas carniceras que optemos por utilizar. En el Cuadro 1 se presenta un resumen de un trabajo desarrollado en la EEMAC durante 3 años que involucra un volumen importante de carneros y razas. Las madres de todos los carneros eran Corriedale, lo que varía es la raza paterna.

Si el lector se detiene a observar la tercera columna, que es el coeficiente de regresión, es decir la pendiente de la recta entre ambas variables, se observa claramente que al incrementar un $\mathrm{kg}$ el peso de canal, el valor GR (Kirton y Johnson, 1979), aumenta más en la raza pura (en este caso Corriedale) frente al conjunto de las razas carniceras $(0,288$ vs. $0,389 \mathrm{~mm}$ más de $\mathrm{GR} / \mathrm{kg}$ de aumento en el peso de canal, respectivamente). Pero además, cuando se analiza hacia el interior de las razas carniceras se observa que también existen diferencias entre ellas, a tal punto que por ejemplo si decidiéramos utilizar Carneros île de France, frente a carneros Hampshire Down o Southdown, el engrasamiento por el mismo $\mathrm{kg}$ de incremento en la canal sería exactamente la mitad. Algo similar ocurriría con el Texel o aun con el Poll Dorset que no aparece en el Cuadro 1.

De la misma forma en el Cuadro 2 se presenta la misma información cambiando la variable de respuesta, en vez de estudiar como variaba el grado de engrasamiento conforme el peso de canal incrementaba en $1 \mathrm{~kg}$, se considera el conjunto de los cortes del trasero de mayor valor: pierna, bife y lomo.

De la misma forma y analizando ahora el mismo valor de la pendiente (tercera columna) del Cuadro 2, se observa que el incremento de un kg de canal en la raza pura (de nuevo Corriedale, que fue la utilizada como testigo en este trabajo) significa menor cantidad de cortes valiosos frente a la utilización de cruzamientos con cualquier raza carnicera $(0,288$ vs. 0,349 más de cortes valiosos/kg de incremento en el peso de canal, respectivamente). De nuevo, queda claro que

Cuadro 1. Asociación entre peso de canal y punto GR (medida objetiva de engrasamiento de la canal) para diferentes razas de carneros utilizados sobre ovejas Corriedale. Modelo de heterogeneidad de pendiente: $G R=m+b$ * $P C F+b i * G i * P C F+e$.

\begin{tabular}{|l|c|c|c|c|}
\hline Raza paterna & Intercepto & $\begin{array}{c}\text { Coeficiente de } \\
\text { regresión (error } \\
\text { estándar) }\end{array}$ & $\begin{array}{c}\text { Coeficiente } \\
\text { de correlación }\end{array}$ & $\begin{array}{c}\text { Coeficiente de } \\
\text { determinación }\end{array}$ \\
\hline Corriedale & $-7,123$ & $1,071( \pm 0,077) \mathrm{Aa}$ & 0,81 & 0,65 \\
Île de France & $-0,058$ & $0,577( \pm 0,116) \mathrm{d}$ & 0,63 & 0,40 \\
Milchschaf & $-4,539$ & $0,710( \pm 0,126) \mathrm{cd}$ & 0,73 & 0,54 \\
Texel & $-3,890$ & $0,858( \pm 0,069) \mathrm{bc}$ & 0,69 & 0,47 \\
Suffolk & $-8,784$ & $0,950( \pm 0,314)$ abcd & 0,87 & 0,76 \\
Southdown & $-7,877$ & $1,087( \pm 0,130)$ ab & 0,88 & 0,78 \\
Hampshire Down & $-7,609$ & $1,037( \pm 0,117)$ ab & 0,77 & 0,59 \\
\hline Promedio de cruzas & $-5,833$ & $0,918(0,046) \mathrm{B}$ & 0,73 & 0,53 \\
\hline
\end{tabular}

$(A, B)$ : diferencias entre raza pura y promedio de las cruzas; $(a, b, c, d)$ : diferencias entre cruzas; $p \leq 0,10$. Fuente: Bianchi et al., (2000). 
Cuadro 2. Relación entre peso de canal fría y peso de cortes valiosos totales (pierna + bife + lomo) en registros provenientes de corderos hijos de padres Corriedale, Texel, Hampshire Down, Southdown, Île de France, Milchschaf y Suffolk y madres Corriedale. Modelo de heterogeneidad de pendiente: $\mathrm{PCV}=\mathrm{m}+\mathrm{b} * \mathrm{PCF}+\mathrm{bi}$ * $\mathrm{Gi}$ * $\mathrm{PCF}+\mathrm{e}$.

\begin{tabular}{|l|c|c|c|c|}
\hline Raza paterna & Intercepto & $\begin{array}{c}\text { Coeficiente de } \\
\text { regresión (error } \\
\text { estándar) }\end{array}$ & $\begin{array}{c}\text { Coeficiente } \\
\text { de correlación }\end{array}$ & $\begin{array}{c}\text { Coeficiente de } \\
\text { determinación }\end{array}$ \\
\hline Corriedale & $+378,1$ & $0,288( \pm 0,010) \mathrm{B} \mathrm{d}$ & 0,93 & 0,86 \\
Texel & $+314,7$ & $0,300( \pm 0,010) \mathrm{cd}$ & 0,97 & 0,95 \\
Hampshire Down & $-649,0$ & $0,350( \pm 0,020)$ ab & 0,94 & 0,87 \\
Southdown & $-549,1$ & $0,348(0,016)$ ab & 0,98 & 0,97 \\
Île de France & $+10,8$ & $0,326( \pm 0,015) \mathrm{bc}$ & 0,97 & 0,94 \\
Milchschaf & $-500,1$ & $0,353 \pm 0,015)$ ab & 0,97 & 0,94 \\
Suffolk & -1908 & $0,413( \pm 0,036) \mathrm{a}$ & 0,96 & 0,92 \\
\hline Promedio de cruzas & $-5,833$ & $0,349( \pm 0.080) \mathrm{A}$ & 0,97 & 0,94 \\
\hline
\end{tabular}

(A, B): diferencias entre raza pura y promedio de las cruzas; $(a, b, c, d)$ : diferencias entre cruzas; $p \leq 0,05$. Fuente: Garibotto y col. (2001).

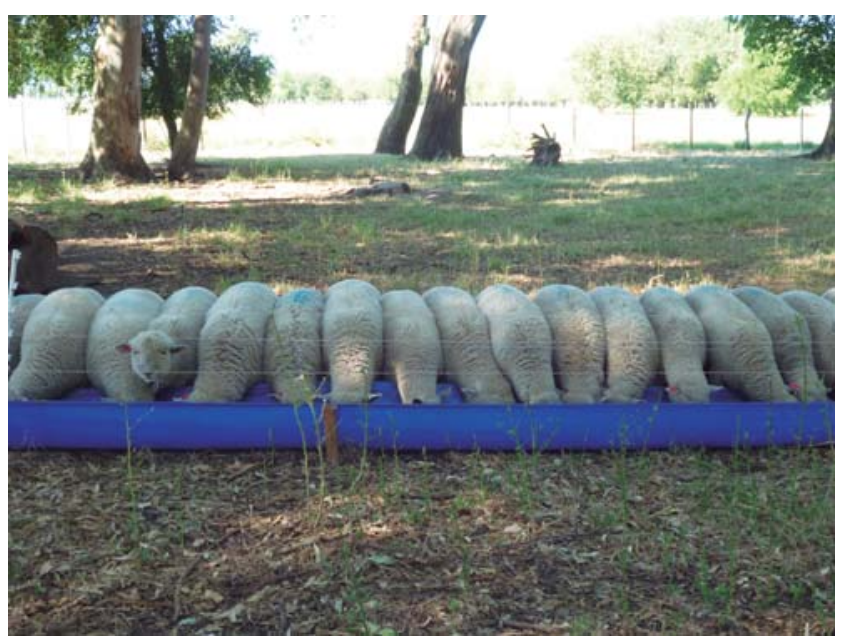

Figura 1. Confinamiento de corderos en verano.

Figura 2. Los corderos que saben comer, mejoran su desempeño en el feed lot hasta un $35 \%$.

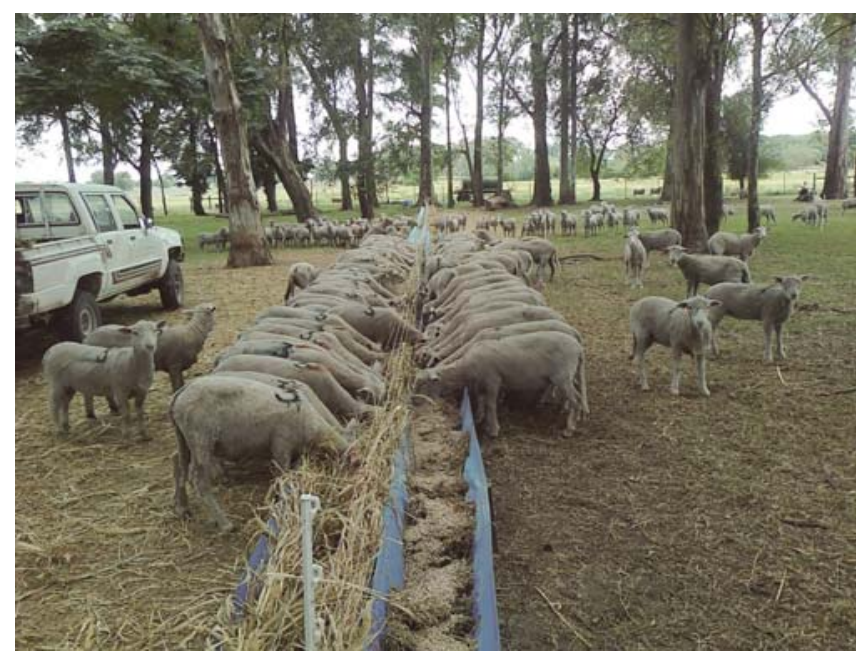


si se pretende producir una canal muy pesada y con cortes de gran calibre no es lo mismo utilizar como carnero ejemplares de la raza Suffolk vs. Texel.

Vale decir que es precisamente en base a esto que Australia opta por incrementar sus canales hasta $22 \mathrm{~kg}$ y utilizar carneros Poll Dorset o White Suffolk y Nueva Zelandia, que en realidad, nada le impediría seguir incrementando el peso de sus canales, «se para» en 18-19 kg de canal y usa Romney. Obviamente que ello responde a los mercados que uno u otro mayoritariamente abastecen (EEUU y UE, respectivamente).

Lamentablemente en Uruguay, se producen canales mayoritariamente con razas no especializadas en producir carne, con lo cual nuestros productos, si bien se exportan, no compiten en calidad con los de Oceanía: ni en peso (apenas alcanzamos $16,5 \mathrm{~kg}$ y no producto precisamente de un programa de mejora genética eficiente, ya que las razas carniceras, a diferencia de las laneras, prácticamente no tienen historia de mejora ninguna y nuestras ovejas se concentran en áreas marginales desplazadas por otras actividades más redituables: soja, árboles, lechería), ni en conformación, ni en calibre de los cortes.

Por último y en lo que tiene que ver con factores de manejo, un correcto acostumbramiento es sin duda el factor más importante, siempre y cuando el animal, ya no sepa comer, en cuyo caso no existe ese período de al menos 15 días en que el animal pierde o a lo sumo mantiene peso. Hecho que trasladado al período de engorde puede determinar diferencias cercanas al $35 \%$ en el crecimiento de un cordero que ya sabía comer frente a un animal no acostumbrado al suplemento. De no saber comer con anterioridad, el acostumbramiento debe ser gradual,

Figura 3. Los primeros días el suplemento es sólo de fibra de buena calidad.
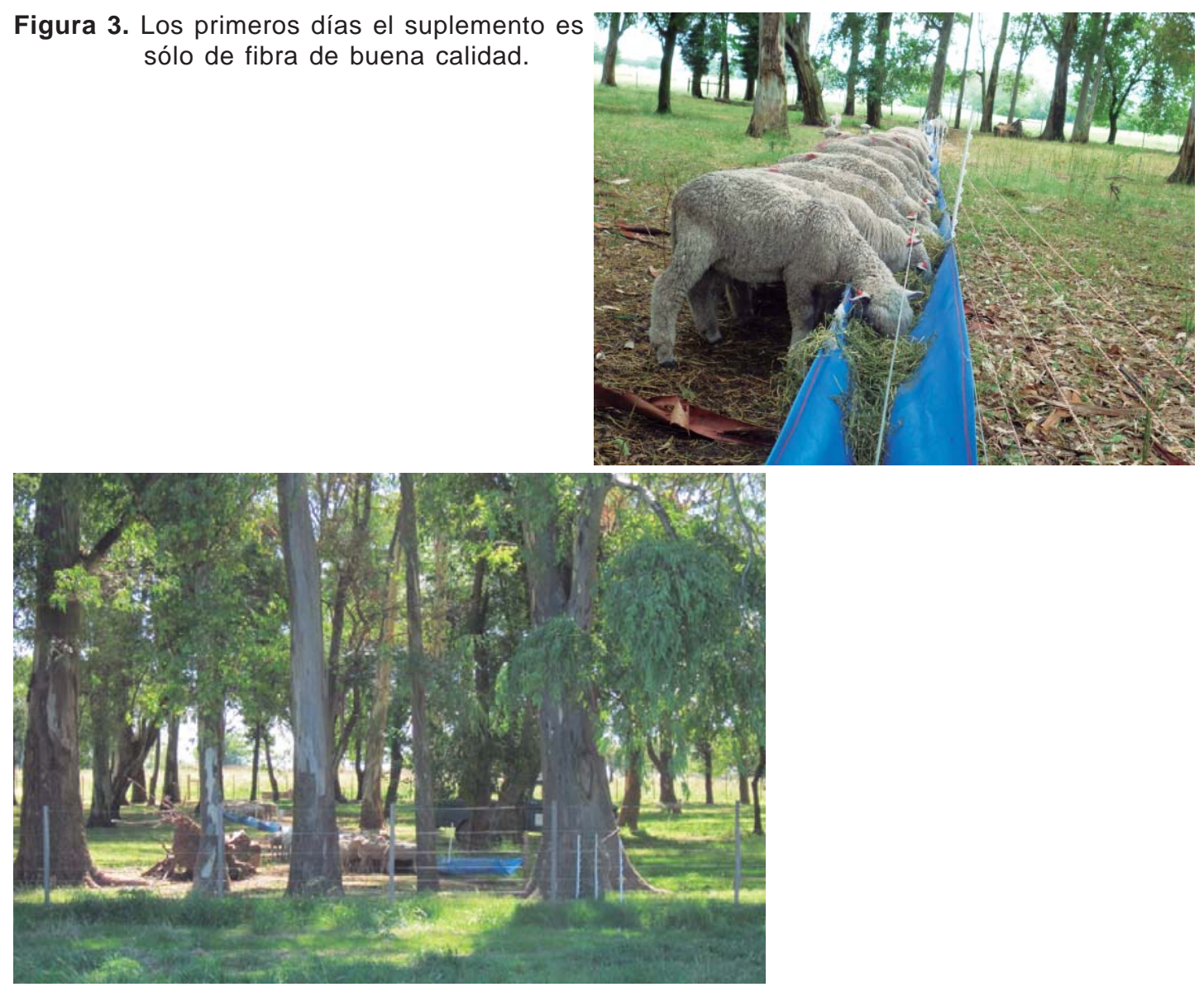

Figura 4. Una isla de eucaliptus convertida en un excelente feed-lot. Al fondo lotes de corderos cruza Finnsheep. 
utilizando primero el voluminoso (sobre todo si es de buena calidad) y luego agregar el concentrado debajo del voluminoso. Es también práctico encerrar los corderos durante la mañana con agua y alimento y largarlos durante la tarde a pastorear. Si hubiera animales que ya saben comer, utilizarlos como señuelos es también una práctica común.

Para llegar a las relaciones de concentado: voluminoso de 90:10 se requieren aproximadamente 4 semanas: En la primera se aumenta progresivamente hasta llegar a 25:75; en la segunda 50:50, en la tercera 75:25 y en la cuarta: 90:10. Los comederos pueden ser de diferente tipo (madera, Iona, goma, etc.), siendo suficiente un frente de ataque de $25-30 \mathrm{~cm} /$ animal, dependiendo si están esquilados o con lana.

Los lotes obviamente deben ser parejos en peso, edad y de un mismo sexo; requiriéndose entre 4-5 $\mathrm{m}^{2} / \mathrm{animal}$. Como ya señaláramos el agua deber ser de buena calidad y ad libitum (siendo suficiente con un frente de ataque de $2 \mathrm{~cm} /$ cordero) y el suministro de alimento (cuando no es una dieta TMR) es mejor separar el concentrado del voluminoso y suministrarlo dos veces al día. Es ampliamente conveniente prever condiciones meteorológicas adversas, siendo importante la protección del alimento sólido (evitar que se moje), así como elegir lugares altos (para evitar anegamiento) y frescos con sombra, particularmente en verano. La mejor presentación es en pellet y si fuera grano entero para favorecer la masticación.

Desde el punto de vista sanitario es primordial no encerrar animales con enferme- dades podales (por razones obvias) y dosificar con el antihelmíntico correspondiente antes del ingreso. Asimismo se recomienda, además de la primo-vacunación contra clostridiosis, un refuerzo dos semanas antes del encierro y seguir los animales durante el encierro. En este sentido evitar trabajar con lotes superiores a los 300 corderos. Es también conveniente encerrar animales esquilados, no sólo por el mayor consumo, sino también por la mayor facilidad para controlar la miasis, además de mantenerlo limpio al momento del embarque.

\section{ALGUNAS EXPERIENCIAS RECIENTES: RESULTADOS BIOLÓGICOS Y ECONÓMICOS}

En el Cuadro 3 se presenta los resultados de una de las últimas experiencias realizadas en la EEMAC el verano pasado. Se encerraron durante 63 días (2/1-6/3/2013) en una isla de Eucaliptus 50 corderas hembras de diferentes biotipos: ${ }^{1 / 2}$ Soutdhown $+{ }^{1 / 2} \mathrm{Me}$ rino Australiano (SDMA; $n=10),{ }^{1 / 2}$ Southdown $+{ }^{1 / 4}$ Romney Marsh $+{ }^{1 / 4}$ Corriedale (SDRMC; $\mathrm{n}=10),{ }^{1 / 2}$ Southdown $+{ }^{1 / 4}$ Finnish Landrace + ${ }^{1 / 4}$ Corriedale (SDFLC; $n=10$ ), ${ }^{1 / 2}$ Southdown $+{ }^{3 / 8}$ Poll Dorset $+{ }^{1 / 8}$ Corriedale (SDPDC; $n=$ 10) $y^{1 / 2}$ Southdown $+{ }^{3 / 8}$ Texel $+{ }^{1 / 8}$ Corriedale (SDTXC; $n=10)$. Los corderos al momento del encierro contaban con una edad y peso vivo de: $105 \pm 6$ días de edad y $27,1 \pm 1 \mathrm{~kg}$ (promedio y desvío estándar, respectivamente).

El acostumbramiento se extendió por 15 días. Para todos los lotes de corderos se

Cuadro 3. Velocidad de crecimiento, peso vivo, engrasamiento y porcentaje de animales que alcanzaron los requisitos del Operativo Cordero Pesado de los corderos.

\begin{tabular}{|l|c|c|c|c|}
\hline Biotipo & $\begin{array}{c}\text { Ganancia media } \\
\text { diaria (g/d) }\end{array}$ & $\begin{array}{c}\text { Peso vivo } \\
\text { (kg) }\end{array}$ & $\begin{array}{c}\text { Estado corporal } \\
\mathbf{( 0 - 5 )}\end{array}$ & $\begin{array}{c}\text { Porcentaje de } \\
\text { corderos con peso } \\
\text { vivo }>\mathbf{3 6} \text { kg y } \\
\text { cc } \geq \mathbf{3 , 5}\end{array}$ \\
\hline SDMA & $240 \pm 60(\mathbf{2 6 0 )}$ & $40 \pm 3$ & 4,1 & 80 \\
SDRMC & $280 \pm 30(\mathbf{3 0 0})$ & $43 \pm 3$ & 4,2 & 100 \\
SDTXC & $290 \pm 30(\mathbf{3 2 0})$ & $45 \pm 2$ & 4,3 & 100 \\
SDFLC & $300 \pm 50(\mathbf{3 2 0})$ & $43 \pm 4$ & 4,1 & 100 \\
SDPDC & $280 \pm 60(\mathbf{3 0 0})$ & $44 \pm 4$ & 4,1 & 100 \\
\hline
\end{tabular}

Fuente: Bianchi y col. (2013). 
utilizó la ración de Molino Victoria (Nutrición Animal) con $2.500 \mathrm{kcal} / \mathrm{kg}$ ( $\pm 10 \%) ; 12 \%$ Humedad; 3\% Extracto Etéreo; 15\% Fibra Cruda; > 13\% Proteína Bruta y 8\% Minerales Totales (Calcio 0,5 - 0,8\% y Fósforo 0,3$0,6 \%$ ), que se suministraba 1 vez/día, de modo que consumieran en torno a $4-4,5 \%$ del peso vivo, con ajuste semanal. Se utilizó -como fuente de fibra- fardo de alfalfa. La relación de suministro fue 80:20, concentrado y fibra, respectivamente.

Los valores de ganancia media diaria entre paréntesis y en negritas corresponden a los registros de todo el período de encierro, excluyendo la semana previa a la esquila. Precisamente en dicha semana se registró una tercera fase, de estancamiento, producto de un temporal de viento y lluvia que transcurrió durante el período 12 al 23/02 (etapa en la cual la ración se mojaba y los corderos la rechazaban; a tal punto que se optó a partir del tercer día por suministrar 3\% del peso vivo sólo del componente fibroso).

Los resultados, tanto de ganancia diaria como de conversión alimenticia, son considerados como muy buenos, e inéditos en lo que a resultados nacionales en feed lot respecta, en particular si se excluye la semana «problema». Es de destacar, dentro de las ganancias obtenidas, las de corderos producto del doble cruzamiento, aprovechando además de la heterosis individual y/o complementariedad entre razas, la heterosis materna, producto de que las madres ya eran cruzas. No obstante, las ganancias obtenidas en los corderos hijos de ovejas Merino Australiano y carneros Southdown, aunque menores, también son muy buenas y fundamentan los planteos productivos de destinar a cruzamientos las ovejas Merino des- cartadas por gruesas u otro defecto en sistemas laneros del Basalto superficial.

En el Cuadro 4 se presentan algunos coeficientes técnicos y los precios de los insumos y productos y en el Cuadro 5 los costos, el producto bruto de carne y lana y el margen/cordero de este engorde.

A modo de comentarios generales y observando los valores de los Cuadros 4 y 5 , surgen como primer elemento destacable el alto costo de la ración utilizada (el fardo también es caro, pero como representa una baja proporción del alimento, pasa casi desapercibido). Obviamente que en este aspecto se puede trabajar bastante, sobre todo por el alto consumo que tiene el cordero cuando se lo compara con el vacuno ( 4,5 vs. $3,0-$ $3,5 \%$ del peso vivo, respectivamente). De todas formas y en conjunto con el costo de la reposición (que siempre hay que considerarlo, aunque sea propia, porque existe la opción de venderla frente a engordarlo uno mismo) representan el 95\% de los costos totales. Por el contrario, se corrobora lo insignificante que representa la sanidad en los costos totales (menos que los impuestos), a pesar de la importancia que tiene en explicar la eficiencia en el engorde de los corderos.

Por el lado del producto y en función del tipo de cordero producido y sobretodo de lo corto del período de engorde y de la baja edad del animal al sacrificio, es inmediatamente obvia la preponderancia de la carne frente a la lana, que explica muy poco, casi nada del producto bruto total. La variable tiempo es fundamental considerarla, ya que cuando analizamos el margen bruto, a priori poco atractivo, es importante compararlo con los márgenes que deja el cordero pesado tradi-

Cuadro 4. Algunos coeficientes técnicos y precios de insumos y productos del engorde a corral.

\begin{tabular}{|l|c|}
\hline Coeficiente técnico o precio & Kg o USD corriente \\
\hline Peso cordero al inicio de engorde & 28,0 \\
Precio/kg de cordero de reposición & 1,41 \\
Peso cordero final de engorde Conversión alimenticia & $4,04,7$ \\
Precio/kg de cordero gordo & 3,75 \\
Precio/tonelada de ración & 414 \\
Precio/tonelada de fardo de alfalfa & 370 \\
\hline
\end{tabular}


Cuadro 5. Costos y margen bruto/cordero durante el período de engorde a corral.

\begin{tabular}{|l|c|}
\hline Costos (\% del total) & USD corrientes/cordero \\
\hline Reposición & $40(55)$ \\
Sanidad & $1(1)$ \\
Mano de obra ${ }^{1}$ & $1,8(2)$ \\
Dieta & $29(40)$ \\
Impuestos & $1,5(2)$ \\
\hline TOTAL & $73,3(100)$ \\
\hline Producto Bruto (\% del total) & $75(96)$ \\
Carne & $3(4)$ \\
Lana & 78 \\
TOTAL & $\mathbf{4 , 7}$ \\
\hline Margen Bruto & \\
\hline
\end{tabular}

1: incluye los costos de esquila.

cional a pasto. En este sentido, se señala como promedio de 10 años un margen bruto de USD17/cordero (considerando la carne y el vellón producido; Salgado, 2013), pero el período de invernada es de 7 meses. Vale decir que una invernada tradicional equivale a casi 3 períodos de engorde en el corral, con lo cual la diferencia de USD 12,3 (17$4,7)$ a favor del cordero pesado tradicional, casi se «emparda» cuando consideramos iguales períodos de engorde: en 7 meses la invernada tradicional deja, según Salgado (2013), USD17/cordero, mientras que este cordero «caro» a corral deja: USD15,7, porque en el mismo período se engordarían a corral 3 corderos. En pastoreo el autor señala una carga de 7 corderos/ha, si no hubiera limitantes de cordero (como veremos las hay) en esa misma superficie se podrían encerrar y engordar 2000 corderos. Con todo esto, lo que pretendemos poner en evidencia es lo ineficiente que resulta tener $7 \mathrm{me}$ ses en el campo un cordero para engordarlo, cuando se podría hacer en menos de la mitad de ese tiempo y maximizar las ventajas que -sin dudas- tiene el engorde a pasto, pero sólo cuando se realiza como se debe.

Más impactantes resultan los datos del lote de cola encerrado también este último verano, particularmente si consideramos el peso y el estado de los corderos previos al encierro de los corderos cuyos resultados se presentan en el Cuadro 6.
Este segundo lote estuvo conformado por 51 corderos (16 hembras y 35 machos) nacidos el 1/9/2012 $\pm 13(17 / 8-2 / 10)$, con un peso vivo de $18 \pm 2 \mathrm{~kg}(20-17 \mathrm{~kg})$ y $17 \pm$ $2 \mathrm{~kg}(20-11 \mathrm{~kg})$, machos y hembras, respectivamente y una edad de $95 \pm 13$ días. Todos los corderos eran hijos de carneros Southdown y madres F1.

Cuando los servicios son prolongados $>45$ días en primavera o > 34 días en otoño) surge un problema, sobre todo en los meses de mayor temperatura, que es la «cola de parición». Estos corderos deben afrontar el verano, ya destetados, con un bajo peso vivo (muchas veces, no superior a $14 \mathrm{~kg}$ o aun 11 $\mathrm{kg}$, como el extremo inferior de las hembras del lote de cola) y con una baja oferta de forraje en cantidad y sobretodo en calidad. La consecuencia normal es la muerte y/o el «apunamiento», que es más o menos lo mismo. La mortalidad neonatal es muy «sentida» por los productores; no obstante las pérdidas que ocurren entre la señalada y el destete, y entre el post-destete y el embarque, pocas veces se toman en cuenta. Entre otras cosas, porque ni siquiera se registran. No es descabellado pensar en porcentajes cercanos a 10$12 \%$ en el período que media entre la señalada y el embarque. Pues bien, la decisión de encerrar todo el «chiquitaje» y los «abichados» al destete resulta una opción a considerar y los resultados obtenidos en este trabajo la muestran como claramente favorable, no sólo 


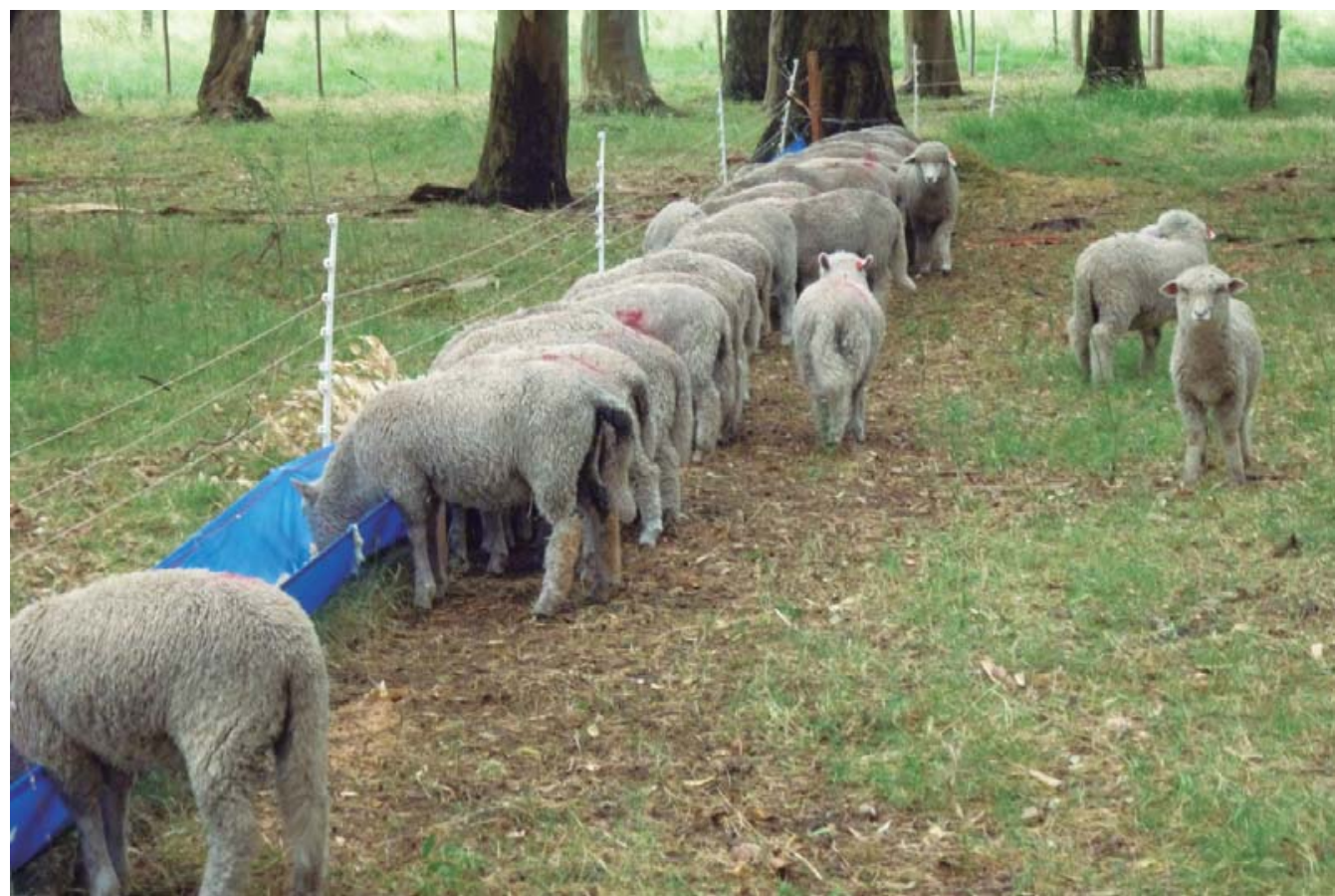

Figura 5. Encerrar el lote de cola es una excelente alternativa para salvarlos de las penurias del verano.

Cuadro 6. Velocidad de crecimiento, consumo y conversión alimenticia de la cola de parición en diferentes períodos de engorde de los corderos.

\begin{tabular}{|c|c|c|}
\hline $\begin{array}{c}\text { Ganancia media diaria } \\
\text { (g/día) }\end{array}$ & Consumo MS/animal/día & $\begin{array}{c}\text { Conversión alimenticia } \\
\text { (kg de alimento/kg } \\
\text { de peso vivo) }\end{array}$ \\
\hline $50 \pm 60$ & $\begin{array}{l}\text { Período de acostumbramiento } \\
\qquad \text { (28 días) } \\
0,27 \\
\text { Período pre-esquila } \\
\text { (52 días) }\end{array}$ & $5,4: 1$ \\
\hline $\begin{array}{c}220 \pm 50(250) \\
330 \pm 70\end{array}$ & $\begin{array}{c}\text { 0,95 } \\
\text { Período post-esquila (11 días) } \\
1,82 \\
\text { Período total de confinamiento } \\
\text { (63 días) }\end{array}$ & $\begin{array}{c}4,3: 1(3,8: 1) \\
5,5: 1\end{array}$ \\
\hline $240 \pm 70(270)$ & 1,1 & 4,5: $1(4,1: 1)$ \\
\hline
\end{tabular}

Nota: Los valores de ganancia media diaria y conversión alimenticia entre paréntesis y en negritas corresponden a los registros de todo el período de encierro, excluyendo la semana previa a la esquila. Fuente: Bianchi y col. (2013). 
por los coeficientes técnicos alcanzados, sino también porque la alternativa de dejarlos en el campo era sumamente riesgosa.

\section{POSIBILIDADES PARA MEJORAR LOS RESULTADOS ECONÓMICOS DEL ENGORDE A CORRAL}

Básicamente tres son a nuestro entender las alternativas adicionales para mejorar los números del corral en corderos.

Una de ellas, ya nos referimos y sería trabajar en la formulación de la dieta para abaratarla: a USD 400 (o más) la tonelada de ración y con el precio actual del cordero, los números no resultan atractivos, aun con coeficientes técnicos como los señalados en este trabajo. Sin embargo y aprovechando como decíamos- el alto consumo por unidad de peso que manifiesta un cordero comiendo ad libitum es posible bajar sensiblemente el precio de la ración y a la vez cumplir con todos los requerimientos del cordero.

En segundo lugar el uso de dietas totalmente mezcladas (TMR) es otra alternativa, ya utilizada en Uruguay (Piaggio y col., 2013). Que sería sumamente útil para con- trarrestar la selectividad que manifiesta el ovino en general y el cordero en particular (Garibotto, 2006).

En tercer y último lugar el uso del autoconsumo no sólo abarataría los costos de mano de obra, sino que mejoraría aún más la conversión alimenticia a la luz de los reportes nacionales de un menor consumo, registrados al menos en terneros a corral (Simeone y col. 2013). El autoconsumo también nos independizaría de las condiciones ambientales.

\section{PAPEL DEL CONFINAMIENTO EN LOS SISTEMAS DE PRODUCCIÓN}

En general, los corderos engordados en confinamiento, frente a los que se mantienen en pastoreo, tienden a presentar mayor velocidad de crecimiento y mejor terminación. Post-mórtem, el rendimiento en segunda balanza también es superior, tendiendo a mostrar tonalidades más claras en la grasa de cobertura, sin efectos importantes en la cantidad de grasa intramuscular. A diferencia de los vacunos, donde sí resulta evidente el efecto del feed lot, particularmente en razas con importante grado de marmoleo.

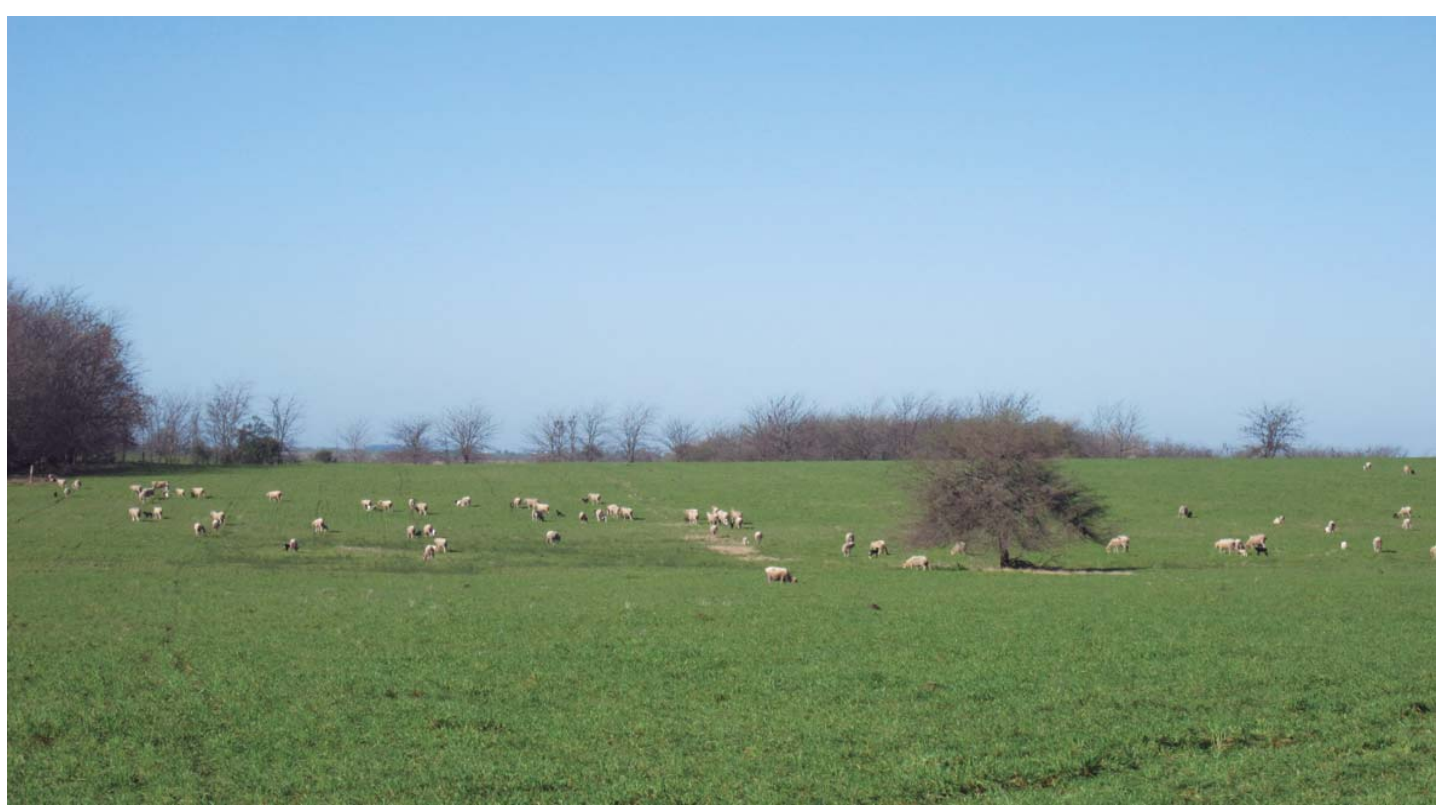

Figura 6. Nuestra fortaleza es (y seguirá siendo) producir pasto y saber utilizarlo; vemos el confinamiento como estratégico y no estructural. 
Tampoco se pueden perder de vista los mercados a los que va destinado el producto final, en lo relativo a costumbres, hábitos culinarios y aceptabilidad de los consumidores (Fonti Furnols et al., 2011). Existen mercados donde la carne proveniente de feed lot es claramente preferida frente a la de origen pastoril.

Por otro lado, al evaluar los resultados de un feed lot, la cuenta siempre se hace considerando el desempeño del animal encerrado, cosa que es natural; pero también es importante no soslayar el efecto que el encierro tiene sobre todo el sistema de producción. En este sentido, en el período en que los animales están encerrados no están pastoreando, lo que permite «agrandar» campo: en épocas de crisis forrajera invernal, para utilizar el escaso recurso forrajero estival de calidad con otra especie animal; o reservar- lo, para el otoño siguiente. A su vez, la alternativa de encerrar corderos para engordarlos puede ser la única posibilidad de algunos sistemas de producción que, ya sea por limitantes agro ecológicas, escala o decisión empresarial de usar los mejoramientos forrajeros sólo con vacunos, se ven imposibilitados de vender corderos pesados en tiempo y forma.

No obstante, desde el punto de vista de la salud humana, la grasa de los corderos alimentados a pasto resulta más adecuada que la de animales contemporáneos alimentados en base a concentrado. Ya que si bien éstos últimos tienen más cantidad de ácidos grasos insaturados en los corderos alimentados a pasto la relación n-6/n-3 es más favorable, existiendo en la carne de estos animales más ácido linoleico conjugado (CLA), con altos contenidos de vitamina $E$

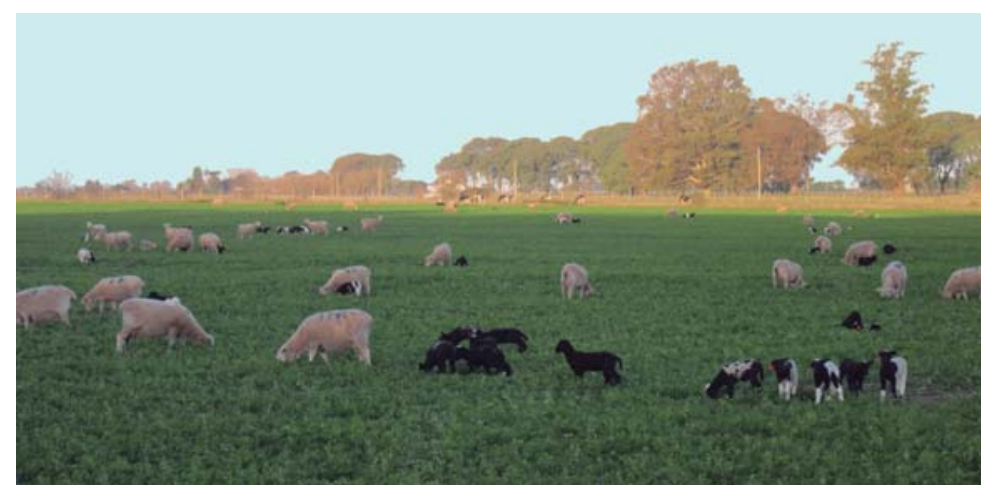

Figura 7. Criadores que utilicen genética suministrada por los que luego engordarán todos esos corderos, ni más ni menos que asociaciones ganar-ganar.

Figura 8. La certeza de que los corderos se levantan en tiempo y forma es una de las claves del feed lot. (Nótese la mansedumbre al subir).

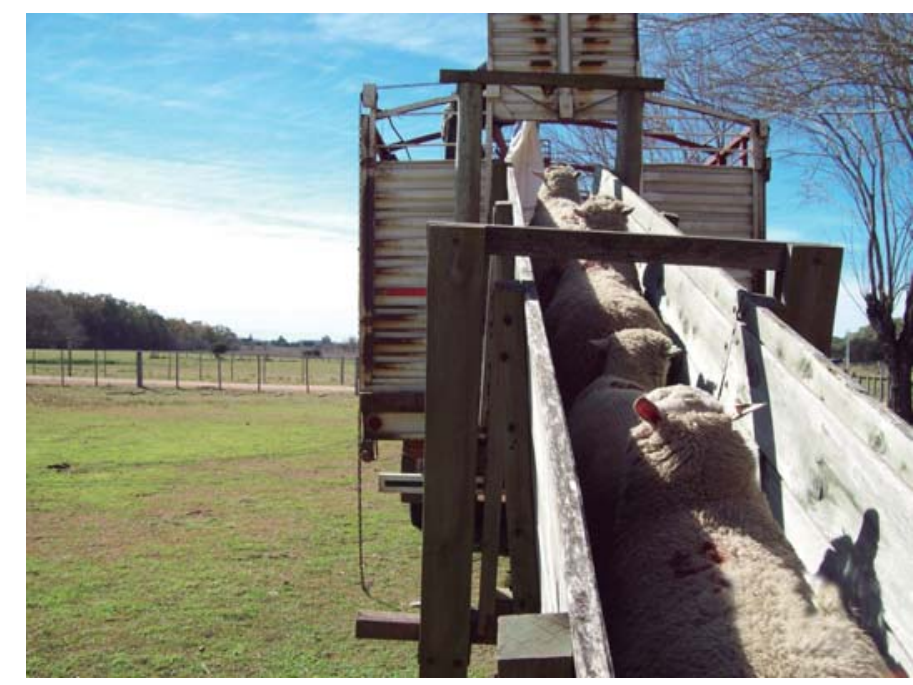


con importantes propiedades anti-oxidantes (Cañeque y col., 2007).

Pero además, y esta es la razón fundamental, el Uruguay tiene ventajas comparativas enormes para desarrollar su producción de carne de corderos (y obviamente vacunos) en pastoreo. El corral puede atender necesidades de un mercado particular, puede también jugar un papel estratégico, pero estructuralmente el país ya tiene una marca registrada a nivel internacional que es la carne producida a pasto, el tema está en saber utilizarlo de la forma más eficiente posible.

\section{PROBLEMAS DEL CONFINAMIENTO FRENTE A EMPRENDIMIENTOS DE GRAN ENVERGADURA}

Dos son los problemas más importantes a resolver en Uruguay para pensar en hacer un feed lot a gran escala y no son precisamente los coeficientes técnicos. Uno es la disponibilidad de corderos para engordar (en realidad su falta) $y$, de la mano de este inconveniente, la heterogeneidad en esa escasa oferta. Vale decir que, salvo para quienes dispongan de corderos en propiedad, es muy difícil pensar en realizar un feed lot. Una alternativa es proporcionar al criador (o criadores) la genética (carneros) para producir los corderos más eficientes, que -como vimos- son los cruzas carniceros. Esto se está intentando implementar en el este con los arroceros y el manejo del laboreo de verano, pero no es fácil.

El segundo y todavía más importante escollo para este sistema es la incertidumbre de venta al preciso momento en que los animales están prontos para ser embarcados. El costo de alimentación como también vimos es significativo; basta calcular lo que implica para un encierro, digamos de 1000 corderos, consumiendo en torno a 1,3 kg MS/ cordero/día (a U\$S 0,30/kg MS, como «barato»), el atraso diario en levantar los corderos, para valorar la magnitud del impacto negativo sobre dicho sistema de alimentación.

Ciertamente este problema también existe en sistemas de engorde a pastoreo, pero en este caso es posible, «tirarlos» para el fon- do del campo, si bien también se pierde, el costo de engorde es muchísimo menor.

\section{BIBLIOGRAFÍA}

AZZARINI, M.; OFICIALDEGUI, R.; CARDELLINO, R. 1996. Sistemas alternativos de producción ovina. Potenciación de la producción de carne en sistemas laneros. S.U.L. Producción Ovina 9: 7-20.

BIANCHI, G.; GARIBOTTO, G.; BENTANCUR, O. 2000. Relation between cold carcass weight and tissue depth in GR site. Effect of breed and sex in pure and crossbred heavy lambs of 5 months of age. En: $46^{\text {th }}$ International Congress of Meat Science \& Technology Buenos Aires. Argentina. pp: 358-359.

BIANCHI, G. 2001. Utilización de razas y cruzamientos para la producción de carne ovina en Uruguay. En: Curso Internacional en salud y producción ovina., 2001 Valdivia Curso Internacional en salud y producción ovina. Universidad Austral de Chile. Facultad de Ciencias Veterinarias. Escuela de Graduados. Valdivia 17 y 18 de mayo 2001. Chile.

BIANCHI, G.; GARIBOTTO, G.; OLIVEIRA, G. 1997. Producción de Carne Ovina en base a Cruzamientos. Universidad de la República. Facultad de Agronomía. 63p.

BIANCHI, G.; GARIBOTTO, G. 2008. Feed lot de corderos: Cuatro años de experiencia en Uruguay. Revista El Borrego $N^{\circ} 50$ : 26-34.

BIANCHI, G. 2010. Calidad de carne y de productos cárnicos ovinos. En: Introducción a la Ciencia de la Carne. Coordinadores: G. Bianchi y O. Feed. Montevideo, Uruguay, Editorial Hemisferio Sur. pp: 259-301.

BIANCHI, G. 2013. Serie Técnica INIA: Proyecto FPTA 254 «Evaluación de la Raza Finnish Landrace en sistemas estratificados de producción de carne, utilizando ovejas Merino Australiano y carneros Poll Dorset». En prensa.

BIANCHI, G.; RIVERO, J.; ROBAINA, F. 2013. Cinco años de experiencia en la «Cassinoni» de la Facultad de Agronomía: Feed lot de corderos. Revista de El País Agropecuario. Abril de 2013. pp: 34-37. 
CAÑEQUE, V.; DE LA FUENTE, J.; DÍAZ, M.T.; ÁLVAREZ, I. 2007. Composición en ácidos grasos y vitamina $E$ de la carne de corderos alimentados con niveles diferentes de concentrado. En: Diferenciación y valorización de la carne Ovina y Bovina del Uruguay en Europa - influencia de sistemas de producción sobre bienestar animal, atributos sensoriales, aceptabilidad, percepción de consumidores y salud humana. INIA Tacuarembó. Serie Técnica № 168: 97- 102.

FONTI FURNOLS, M.; REALINI, C.; MONTOSSI, F.; SAÑUDO, C.; CAMPO, M.M.; OLIVER, M.A.; NUTE, G.R.; GUERRERO, L. 2011. Consumer's purchasing intention for lamb meat affected by country of origin, feeding system and meat price: A conjoint study in Spain, France and United Kingdom. Food Quality and Preference--22: 443-451.

GARIBOTTO, G.; BIANCHI, G.; BENTANCUR, O. 2001. Análisis de registros de 8 experimentos de cruzamientos ovinos en el Uruguay. Efecto de la relación entre el peso de canal fría y cortes de alto valor en corderos pesados puros y cruza de 5 meses de edad. XVII Reunión Latinoamericana de Producción Animal. II Congreso Internacional de Ganadería de Doble Propósito.VI Encuentro Regional de Especies Mono gástricas. Encuentro Regional sobre Transferencia Tecnológica en la Producción Animal Tropical. 19 al 23 de noviembre del 2001. Palacio de las Convenciones, Ciudad de la Habana, Cuba.

GARIBOTTO, G.; ARBELETCHE, P.; BIANCHI, G. 2003. Producción de carne ovina de calidad: Evaluación física y económica en base al análisis de registros de 9 empresas. EEMAC. Revista Cangüé 24: 41-48.

GARIBOTTO, G. 2006. Alternativas nutricionales para el engorde y terminación de corderos. Jornada de Ovinos: «Producción de corderos pesados y súper pesados precoces». 23 de marzo de 2006. Paysandú. Uruguay. Publicación Ocasional.

GARIBOTTO, G.; BIANCHI, G. 2006. Confinamiento (feed lot) de corderos durante el verano: Una opción que se abre paso. Revista La Propaganda Rural N¹576: $30-32$.
GARIBOTTO, G.; BIANCHI, G. 2007. Alternativas nutricionales con diferente grado de intensificación y su efecto en el producto final. Capítulo VI. G. Bianchi. Alternativas tecnológicas para la producción de carne ovina de calidad en sistemas pastoriles. Ed. Hemisferio Sur. pp: 161-226.

GARIBOTTO, G.; BIANCHI, G.; FERNÁNDEZ, M.E.; BENTANCUR, O. 2009. Efecto de la suplementación y del biotipo materno sobre el desempeño de ovejas y corderos únicos y mellizos pastoreando campo natural. 32 Congreso Argentino de Producción Animal, 2009 Mendoza, Argentina.

KIRTON, A.H.; JOHNSON, D.L. 1979. Interrelationships between GR and other lamb carcass fatness measurements. Proceedings of the New Zealand Society of Animal Production 39: 194-201.

PIAGGIO, L.; COR, P.; PLAVÓN, V.; TELLECHEA, V.; DEL PINO, L.; DESCHENAUX; H. 2013. Engorde a corral para la producción de Cordero Pesado Precoz. SUL. Revista Lana-Noticias 163: 10-14.

RIVERO, J.; GARIBOTTO, G.; BIANCHI, G. 2012. EI uso de concentrado (y fibra) ad libitum en corderos encerrados o pastoreando campo natural en otoño. Revista de El País Agropecuario. Octubre de 2012. pp: 26-28.

RIVERO, J.; ROBAINA, F.; BIANCHI, G. 2013 a. Creep feeding: una alternativa fácilmente adaptable para la Región de Basalto. Revista Lana-Noticias 165. En prensa.

RIVERO, J.; ROBAINA, F.; BIANCHI, G. 2013 b. Una opción para Sistemas Ovinos Intensivos: Creep feeding sobre pastura de alfalfa. Revista de El País Agropecuario. Agosto de 2013. pp: 18 -20.

SALGADO, C. 2013. La invernada de corderos recupera sus resultados económicos históricos. En: SUL Información de Mercado. El Mercado de Carne Ovina. $\mathrm{N}^{\circ}$ 144. $6 p$.

SIMEONE, A.; BERETTA, V.; ELIZALDE, J.C.; CAORSI, J.; VIERA, G. 2013. Raciones totalmente mezcladas suministradas a terneros en comederos de autoconsumo. $15^{a}$ Jornada Anual de la Unidad de Producción Intensiva de Carne. Simplificando la Intensificación Ganadera: El autoconsumo. Facultad de Agronomía. EEMAC: UPIC. pp: 62 -67. 

USO DEL RIEGO EN PASTURAS CON

DESTINO AL ENGORDE DE CORDEROS

D. Formoso ${ }^{123}$

H. Norbis ${ }^{1}$

\section{RESUMEN}

En setiembre de 2010 se instalaron en la Estación Experimental de Secretariado Uruguayo

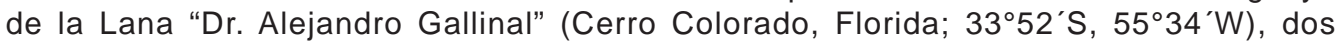
sistemas de riego por aspersión o riego presurizado (pivot o spinner e irripod) para regar pasturas destinadas al engorde de corderos y manejo estratégico de bovinos con el objetivo de obtener coeficientes técnicos para los sistemas ganaderos. Las pasturas fueron dos de ciclo corto (Cychorium intybus cV INIA Lacerta, achicoria; y Lolium hybridum cV Banquett II, ambos con Trifolium pratense cv Estanzuela 116, trébol rojo) y tres pasturas de ciclo largo (Festuca arundinacea cv Rizomat con Trifolium repens cv Zapicán, trébol blanco; y Lotus uliginosus cv Grassland Maku respectivamente, y Lotus uliginosus cv Grassland Maku). En 2011 y 2012, F. Rizomat con trébol blanco y L. Maku fueron las que produjeron más forraje (23,0 y 26,3; 21,3 y 25,9 Ton/ha respectivamente). En rendimiento animal, F. Rizomat con trébol blanco fue la pastura de mejor desempeño (1173 y $1491 \mathrm{~kg}$ de ganancia de peso vivo/ha en 2011 y 2012 respectivamente), mientras que L. Maku y ambas pasturas de ciclo corto, achicoria y L. Banquet II con trébol rojo fueron las de mejor rendimiento ovino en 2011 (585, 795 y 806 kg de cordero/ha) y 2012 (1123, 924 y 909 kg de cordero/ha) respectivamente. Con los datos obtenidos se presentan estimaciones de consumo (ovino y bovino), eficiencia de cosecha y eficiencia de utilización así como la evolución de la cobertura/abundancia de las especies sembradas en la composición de la pastura. Los resultados económicos se realizaron con la producción y costos del riego en 2012 sobre L. Makú, donde hubo pastoreo sólo ovino con mejor desempeño.

Palabras clave: riego por aspersión, pasturas, engorde de corderos

\section{INTRODUCCIÓN}

El riego suplementario es una herramienta que reduce el efecto del déficit hídrico como factor limitante del potencial productivo de especies y cultivares utilizados como forrajeras. Esta herramienta genera una estabilización de la producción de forraje (Sawchik, 2012), aumentado la persistencia e incrementando la calidad (energía y proteína), siendo un factor clave para la obtención sostenida de procesos fisiológicos de alta exigencia nutricional.

Por lo tanto, la incorporación del riego suplementario en pequeñas áreas estratégicas, permitiría a los sistemas ganaderos espe- cializarse en la producción de carne ovina de calidad, mejorando la competitividad del rubro a través de mayor productividad y por consiguiente un mejor ingreso.

En general, se sabe que las especies de clima templado tipo C3 (gramíneas y leguminosas) tienen la máxima actividad fotosintética entre 18,3 y $23,9^{\circ} \mathrm{C}$, mientras que las tropicales (C4) entre 29,4 y $37,8^{\circ} \mathrm{C}$, por lo que se siembran y se riegan más especies de clima templado porque pueden producir a bajas tasas durante el verano, mientras que las tropicales no producen en invierno, aún bajo riego (Volesky et al., 2003).

A su vez, los efectos del riego sobre la producción de pasturas son menos estudia-

${ }^{1}$ Ings. Agróns., Área de Investigación y Desarrollo, Secretariado Uruguayo de la Lana.

${ }^{2}$ INIA, Técnico del Programa Pasturas y Forrajes.

${ }^{3}$ Facultad de Ciencias Agrarias (UDE). 
dos (o difundidos) que sobre cultivos, lo que incrementa las interrogantes a despejar porque los encargados de realizar la cosecha serán animales y no máquinas. Sin embargo, los resultados que se están obteniendo en el país son promisorios (Giorello y col., 2012).

Entre las especies templadas, existe información publicada nacional y regional de rendimiento bajo riego de festuca, raigrás, trébol rojo, trébol blanco, alfalfa y lotus corniculatus (Duhalde, 2001; Schiripia y col., 1995; Formoso, 2007; Pérez Gomar y Silveira, 2009). A modo de resumen de la información precedente, el rendimiento promedio de las pasturas regadas se encuentra entre 10 -17 kg de materia seca por milímetro aplicado. En Lotus uliginosus cv Grassland Makú existen experiencias no publicadas para producción de semilla, así como de Lotus tenuis (L.major) asociado a festuca y alfalfa en suelos de cristalino.

En 2010, el Secretariado Uruguayo de la Lana (SUL) estimó necesaria la generación de información en la utilización del riego suplementario para la producción ovina en particular y la ganadería en general. Con tal motivo se instaló en el Centro de Investigación y Experimentación «Dr. Alejandro Gallinal» (CIEDAG) en Cerro Colorado, Florida, un área de riego con el objetivo de obtener coeficientes técnicos evaluando la respuesta productiva de diversas especies forrajeras bajo pastoreo y sin restricciones hídricas.

El sistema de producción al que se dirige la tecnología del riego es un sistema que aplica todas las técnicas evaluadas en producción de forraje (cultivares, época de siembra, fertilización, manejo del pastoreo, tiempo de descanso) y engorde de corderos (pastoreo horario, suplementación, cargas variables) para conformar un resultado que sea económicamente rentable y atractivo.

Además del objetivo productivo, la secuencia de pasturas bajo riego se realiza con un criterio de control ambiental minimizando el riesgo de erosión y mejorando la estructura y fertilidad del suelo.

\section{MATERIALES Y MÉTODOS}

\section{Localización y características del área de riego}

El área de riego está localizada en

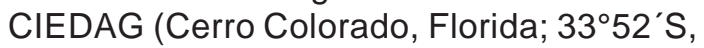
$\left.55^{\circ} 34^{\prime} \mathrm{W}\right)$.

El área potencial a regar es de 45 ha e incluye suelos de la unidad San GabrielGuaycurú, de fertilidad media a alta y con un índice CONEAT de 114.

Estos tipos de suelos son de textura franca en sus primeros $20 \mathrm{~cm}$, con $4 \%$ de materia orgánica, $\mathrm{pH}$ de 5,7; 26 ppm de nitrógeno como nitratos (N-NO3) y 3 ppm de fósforo Bray $\mathrm{N}^{0} 1$. Los niveles de meq/100 $\mathrm{g}$ de suelo son de 4,$1 ; 1,7$ y 0,29 para $\mathrm{Ca}, \mathrm{Mg}$ y $\mathrm{K}$ respectivamente.

La capacidad de almacenamiento entre 0-25 cm de profundidad es de $62 \mathrm{~mm}$, y $74 \mathrm{~mm}$ entre $25-50 \mathrm{~cm}$, mientras que la velocidad de infiltración a suelo saturado es de $1,7 \mathrm{~mm} \mathrm{~h}^{-1}$.

\section{Sistemas de riego instalados}

La fuente de agua es una represa con una capacidad de almacenaje de $132000 \mathrm{~m}^{3}$, con un espejo de aproximadamente 7 ha $y$ 132 ha de cuenca.

El área potencial a regar por aspersión es de 45 ha e incluye suelos de la unidad San Gabriel-Guaycurú, de fertilidad media a alta y con un índice CONEAT de 114.

Los sistemas móviles de riego por aspersión (riego presurizado) que se instalaron fueron un mini pívot «Spinner» con seis posiciones posibles y un área total a regar de 21 ha. Por otro lado, un sistema de aspersores móviles (sistema «Irripod») con un área de riego de 7,4 ha. Ambos equipos están diseñados para aplicar una lámina de $28 \mathrm{~mm}$ por semana y funcionan con energía eléctrica.

Las decisiones de cuándo y cuánto regar se realizan con el soporte técnico del sistema IRRIGA (Universidad Federal de Santa María, Brasil) gestionado por INIA. 


\section{Especies y Cultivares a regar}

La selección de las pasturas se realizó eligiendo los productos con mayor información disponible utilizando especies y cultivares de genética nacional y/o ampliamente conocidos por los productores como forma de tener un «testigo» implícito y de gran amplitud para comparar los efectos del riego en el desarrollo de las pasturas.

Los materiales que satisfacían estos requisitos, además de la aptitud para el tipo de suelo y la topografía del área, fueron Festuca arundinacea cv Rizomat; Trifolium repens cv Zapicán; Trifolium pratense cv Estanzuela 116; Cychorium intybus cv INIA Lacerta y Lotus uliginosus cv Grassland Maku. Como novedad se incluyó el Lolium hybridum cv Banquett II, tetraploide, seleccionado por su digestibilidad y alto contenido en carbohidratos solubles, con un endófito (Endo 5) que le confiere resistencia a plagas pero no es nocivo para los animales.
Los cultivares se combinaron en cinco pasturas, organizadas arbitrariamente en pasturas de ciclo largo y corto (Cuadro 1).

Las pasturas fueron sembradas el 22/9/2010 con el método de siembra directa sobre un rastrojo de soja que fue sembrada para limpiar el área de riego.

El crecimiento de las pasturas se evaluó mediante jaulas de exclusión (dos jaulas en el Spinner, una en el Irripod, cortando una superficie dentro de la jaula de 0,50 x 0,20 m con tijera de aro dejando un rastrojo de 1-2 cm. El material colectado fue secado en microondas según la técnica sugerida por Petruzzi y col. (2005) y Crespo y col. (2007).

Previo al corte de crecimiento se realizó una estimación de la cobertura/abundancia de las especies en el cuadro de muestreo. A los efectos de simplificar los resultados, se presentan los registros correspondientes a las especies sembradas y otros (donde se agrupa la cobertura de otras especies incluyendo el suelo desnudo).

Cuadro 1. Densidad y fertilización a la siembra, tamaño de parcela y refertilización. ${ }^{4}$

\begin{tabular}{|c|c|c|c|c|c|c|c|}
\hline \multirow{2}{*}{\multicolumn{2}{|c|}{ Pasturas }} & \multirow{3}{*}{\begin{tabular}{|c|}
$\begin{array}{c}\text { Densidad de } \\
\text { siembra }^{(1)}\end{array}$ \\
2,9
\end{tabular}} & \multirow{3}{*}{$\begin{array}{c}\mathbf{N}^{\circ} \text { de ha } \\
2,2\end{array}$} & \multicolumn{2}{|c|}{ Fertilización } & \multicolumn{2}{|c|}{ Re-fertilización } \\
\hline & & & & \multirow{2}{*}{$\begin{array}{c}\text { Fertilizante } \\
7 / 40 / 0\end{array}$} & \multirow{2}{*}{$\frac{\mathrm{kg} / \mathrm{ha}}{230}$} & \multirow{2}{*}{$\begin{array}{c}\text { Fertilizante } \\
\text { Fosforita }\end{array}$} & \multirow{2}{*}{$\begin{array}{r}\frac{\mathrm{kg} / \mathrm{ha}}{(2)} \\
270\end{array}$} \\
\hline$\stackrel{\circ}{\circ}$ & LMaku & & & & & & \\
\hline $\begin{array}{l}\frac{\pi}{0} \\
\frac{0}{0} \\
\frac{-1}{0}\end{array}$ & $\begin{array}{c}\text { FRizomat } \\
+\end{array}$ & 18,5 & & & & $\begin{array}{c}18 / 46 / 0 \\
+\end{array}$ & $\begin{array}{c}300 \\
+ \\
\end{array}$ \\
\hline$\approx$ & LMaku & & 2,9 & 12/52/0 & 220 & $0-46-0$ & $100^{(3)}$ \\
\hline 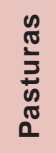 & $\begin{array}{c}\text { FRizomat } \\
+ \\
\text { Tblanco }\end{array}$ & $\begin{array}{c}18,5 \\
1,5\end{array}$ & 3 & $12 / 52 / 0$ & 220 & $18 / 46 / 0$ & 300 \\
\hline $\begin{array}{l}0 \\
\stackrel{0}{0} \\
0 \\
\frac{0}{U} \\
\frac{U}{U} \\
0\end{array}$ & $\begin{array}{l}\text { Raigrás } \\
+ \\
\text { Trojo }\end{array}$ & $\begin{array}{c}16 \\
7\end{array}$ & 2,8 & $25 / 33 / 0$ & 220 & $18 / 46 / 0$ & 300 \\
\hline 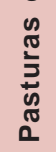 & $\begin{array}{l}\text { Achicoria } \\
+ \\
+ \\
\text { Trojo }\end{array}$ & $\begin{array}{c}5,8 \\
7\end{array}$ & 2,6 & $25 / 33 / 0$ & 220 & $18 / 46 / 0$ & 300 \\
\hline
\end{tabular}

${ }^{1}$ La semilla fue curada y peleteada.

${ }^{2}$ La refertilización se realizó fraccionando en mitades, otoño y a fines de invierno.

${ }^{3}$ La refertilización fue realizada en otoño-invierno 2011.

${ }^{4}$ Las pasturas fueron fertilizadas nuevamente en 2013 (datos no incluidos en el presente trabajo). 


\section{RESULTADOS Y DISCUSIÓN}

\section{Producción animal (ovinos y bovinos)}

Las diferentes pasturas fueron pastoreadas con corderos en engorde hasta llegar a peso y condición de embarque como cordero pesado. En las mezclas con Festuca se utilizaron bovinos para un mejor aprovechamiento y acondicionamiento de la gramínea.

La estrategia de pastoreo se adecuó a la oferta de cada pastura y a la carga asigna$\mathrm{da}$, desde pastoreo diferido en tres parcelas por pastura hasta pastoreo continuo, priorizando en todos los casos la simplicidad de manejo (Cuadro 2).

En el primer periodo del año (enero - abril de 2012) se asignaron cargas ovinas muy altas, manifestándose problemas sanitarios en forma aguda (nemátodes gastrointestina- les) que determinaron bajas ganancias de peso vivo individual en el periodo con la consiguiente pérdida de forraje.

Estos sucesos indican que por las condiciones ambientales que prevalecen en pasturas bajo riego (alta humedad y concentración de animales), se deben tomar precauciones en la asignación de carga y manejo del pastoreo con ovinos y protocolizar un seguimiento exhaustivo de los aspectos sanitarios para un efectivo control.

\section{Producción de pasturas}

La producción total anual de materia seca para cada pastura duplican a los registros proporcionados por Formoso y col. (2013) para pasturas sembradas en secano en el CIEDAG para manejo de ovinos, destacando una respuesta positiva al riego con el agregado de nutrientes (Cuadro 3).

Cuadro 2. Ganancia de peso vivo (GPV ha-1) de corderos y bovinos en 2011 y 2012.

\begin{tabular}{|c|c|c|c|c|c|c|}
\hline \multirow[b]{2}{*}{ Pastoreos } & & \multicolumn{5}{|c|}{ GPV ha ${ }^{-1}$} \\
\hline & & $\begin{array}{c}\text { Achicoria } \\
+ \\
\text { Trébol rojo }\end{array}$ & $\begin{array}{c}\text { Raigrás } \\
\text { Banquet II } \\
+ \\
\text { Trébol rojo }\end{array}$ & $\begin{array}{c}\text { Festuca } \\
\text { Rizomat }+ \\
\text { Trébol blanco }\end{array}$ & $\begin{array}{c}\text { Festuca } \\
\text { Rizomat + } \\
\text { Lotus Maku }\end{array}$ & Lotus Maku \\
\hline AÑO 2011 & Ovinos & 795 & 806 & 496 & 150 & 585 \\
\hline 23/09/10- 21/12/11 & Bovinos & 185 & 201 & 677 & 606 & 75 \\
\hline Total & & 980 & 1007 & 1173 & 756 & 660 \\
\hline $\begin{array}{l}\text { AÑO } 2012 \\
\text { 05/01/12- 03/01/13 }\end{array}$ & $\begin{array}{l}\text { Ovinos } \\
\text { Bovinos }\end{array}$ & 924 & 909 & $\begin{array}{l}776 \\
715\end{array}$ & $\begin{array}{l}492 \\
534\end{array}$ & 1123 \\
\hline Total & & 924 & 909 & 1491 & 1026 & 1123 \\
\hline
\end{tabular}

Cuadro 3. Producción total anual de materia seca (toneladas por hectárea) por pastura en los periodos 23/09/2010 al 21/12/2011 y 05/01/2012 al 03/01/2013.

\begin{tabular}{|l|c|c|c|c|c|c|}
\hline \multirow{2}{*}{} & \multirow{2}{*}{} & \multicolumn{5}{|c|}{ Pasturas } \\
\cline { 3 - 7 } & & $\begin{array}{c}\text { Achicoria } \\
+ \\
\text { Trébol rojo }\end{array}$ & $\begin{array}{c}\text { Raigrás } \\
\text { Banquet II } \\
+\end{array}$ & $\begin{array}{c}\text { Festuca } \\
\text { Trébol rojo } \\
\text { Rizomat + } \\
\text { Trébol blanco }\end{array}$ & $\begin{array}{c}\text { Festuca } \\
\text { Rizomat + } \\
\text { Lotus Maku }\end{array}$ & Lotus Maku \\
\hline $\begin{array}{l}\text { AÑO 2011 } \\
\text { 23/09/10- 21/12/11 }\end{array}$ & ton/MS/ha & 18,4 & 19,4 & 23,0 & 14,5 & 21,3 \\
\hline $\begin{array}{l}\text { AÑO 2012 } \\
\text { 05/01/12- 03/01/13 }\end{array}$ & ton/MS/ha & 20,6 & 18,2 & 26,3 & 19,3 & 25,9 \\
\hline
\end{tabular}




\section{Estimación del consumo de forraje, eficiencia de cosecha y eficiencia de conversión}

Para el año 2012, una vez estabilizada la producción de las pasturas, se estimó el consumo de forraje de los ovinos y bovinos en función del peso vivo, la ganancia de peso individual y la carga animal en cada periodo de pastoreo y para cada pastura; la eficiencia de cosecha (\%) y la eficiencia de conversión de forraje en $\mathrm{kg}$ de peso vivo (Cuadro 4).

La eficiencia de cosecha de Lotus Makú está condicionada en parte por el tipo vegetativo de la planta (estoloníferarizomatosa), dado que los corderos no consumen estolones mientras que éstos son colectados en los cortes de evaluación del crecimiento.

A su vez, una eficiencia similar a L.Makú puede observarse en la mezcla Achicoria + Trébol Rojo, quizás por la pérdida de hojas que se produce debido a la preferencia por la leguminosa de parte de los ovinos que pospone el consumo de Achicoria.

\section{Evolución de la composición florística}

A los efectos de analizar dinámica de la vegetación, se presenta la composición de la pasturas en tres veranos consecutivos (2010 a 2012), expresada en porcentaje, considerando el suelo descubierto como componente del área relevada.

\section{Pasturas de ciclo corto Achicoria + Trébol rojo}

La cantidad de forraje producido estuvo compuesta al comienzo del pastoreo por Achicoria principalmente, hasta su descenso por las cargas utilizadas y el receso en otoño (Figura 1). El pastoreo horario realizado permitió la recuperación en la composición de la mezcla seguida de un incremento del T rojo a partir de primavera (6/09) con un pico de la leguminosa en verano.

Esta evolución es esperable, así como el aumento de la población de «pasto blanco» (Digitaria sanguinalis) con el transcurso del tiempo, similar a lo ocurrido durante el periodo de instalación de la mezcla.

Cuadro 4. Consumo de materia seca (MS ha-1) por especie animal y por pastura en 2012; eficiencia de cosecha (kg MS consumida/producción de MS) y eficiencia de conversión (kg MS consumida/kg GPV) (datos elaborados en base a Crempien, 1978).

\begin{tabular}{|c|c|c|c|c|c|c|}
\hline \multirow[b]{2}{*}{ Pastoreos } & & \multicolumn{5}{|c|}{ Pasturas } \\
\hline & & $\begin{array}{c}\text { Achicoria } \\
+ \\
\text { Trébol rojo }\end{array}$ & $\begin{array}{c}\text { Raigrás } \\
\text { Banquet II } \\
+ \\
\text { Trébol rojo }\end{array}$ & $\begin{array}{c}\text { Festuca } \\
\text { Rizomat + } \\
\text { Trébol blanco }\end{array}$ & $\begin{array}{c}\text { Festuca } \\
\text { Rizomat + } \\
\text { Lotus Maku }\end{array}$ & Lotus Maku \\
\hline $\begin{array}{l}\text { Co n s u mo } \\
\text { (kg MS/ha) }\end{array}$ & $\begin{array}{l}\text { Ovinos } \\
\text { Bovinos }\end{array}$ & 9207 & 9826 & $\begin{array}{c}7197 \\
10539\end{array}$ & $\begin{array}{l}4563 \\
6293\end{array}$ & 10783 \\
\hline Total & & 9207 & 9826 & 17736 & 10856 & 10783 \\
\hline $\begin{array}{l}\text { Eficiencia de } \\
\text { cosecha (\%) }\end{array}$ & $\begin{array}{l}\text { Ovinos } \\
\text { Bovinos }\end{array}$ & 45 & 54 & $\begin{array}{l}27 \\
40\end{array}$ & $\begin{array}{l}24 \\
33\end{array}$ & 42 \\
\hline Total & & 45 & 54 & 67 & 57 & 42 \\
\hline $\begin{array}{l}\text { Eficiencia de } \\
\text { conversión } \\
\text { (utilización) }\end{array}$ & $\begin{array}{l}\text { Ovinos } \\
\text { Bovinos }\end{array}$ & 10 & 10,8 & $\begin{array}{c}9,3 \\
14,7\end{array}$ & $\begin{array}{r}9,3 \\
11,8\end{array}$ & 9,6 \\
\hline
\end{tabular}




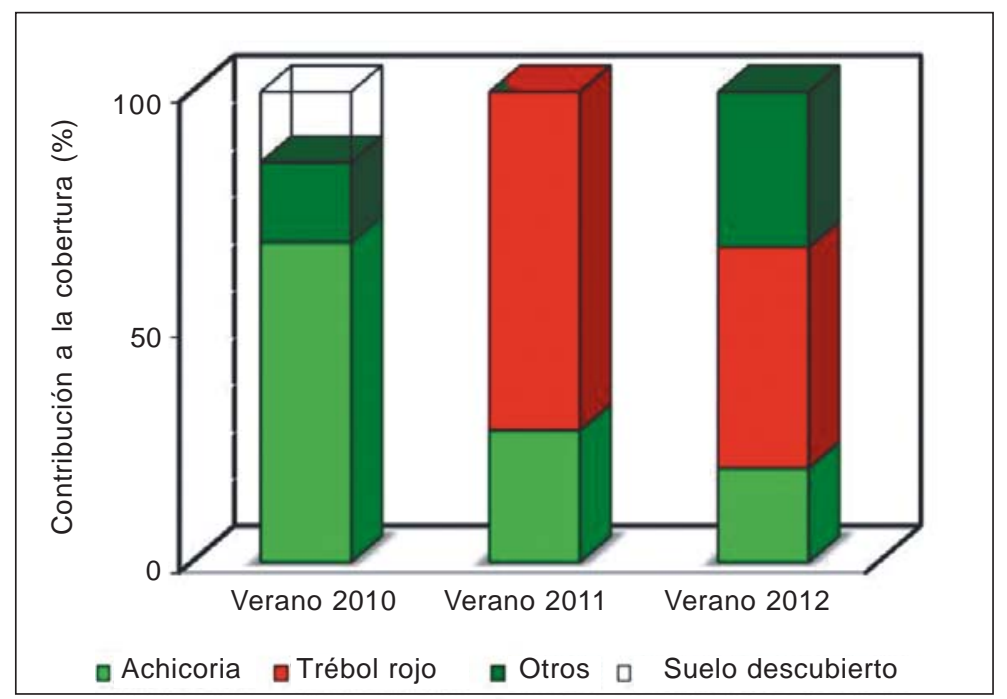

Figura 1. Evolución de la cobertura/abundancia de las especies sembradas.

La introducción de bovinos estuvo dirigida a controlar el crecimiento de la pastura (cañas florales de la Achicoria), complementado con el pasaje de rotativa para eliminar los restos no consumidos (Figura 2).

En esta pastura, las especies sembradas disminuyeron su contribución, presentándose un incremento significativo de raigrás criollo en este invierno 2013. Se estima que la vida útil de la pastura comienza a declinar.

\section{Raigrás + Trébol rojo}

El Trébol rojo produjo grandes cantidades de forraje en los dos primeros años (2010 y 2011) coincidiendo con las características conocidas para esta especie (Figura 3).

En el invierno 2013, el raigrás híbrido y el raigrás criollo son las especies con mayor cobertura/abundancia en la pastura. El T rojo disminuyó significativamente y el suelo no se cubre totalmente durante este periodo de bajas temperaturas y días cortos. Al igual que la pastura anterior, se evalúa su continuidad como mezcla productiva para 2014, previo a un engorde de corderos en primavera 2013 (Figura 4).

\section{Pasturas de ciclo largo Festuca Rizomat + Trébol blanco}

La evolución de esta mezcla muestra un sostenido predominio de las especies sembradas, ambas con arquitectura similar lo que les permite soportar altas presiones de pastoreo tanto ovinas como bovinas (Figura 5).

En el invierno 2013 se destaca un creciente predominio de la festuca con un progresivo retroceso del trébol blanco. En primavera de 2012 se procedió a cortar la floración de la gramínea mediante rotativa, despanojándola a nivel de la hoja bandera.

La floración abre una «fosa fisiológica» de magnitud que la planta debe atender traslocando nutrientes por lo que reduce su aporte en masa vegetativa debilitando innecesariamente los macollos encargados de producir forraje (Figura 6).

\section{Festuca Rizomat + Lotus Makú}

Esta mezcla fue pastoreada con ovinos en el primer otoño (2011) luego de la siembra de primavera afectando la formación de rizomas por parte de la leguminosa y enlenteciendo su instalación. Por tal motivo 


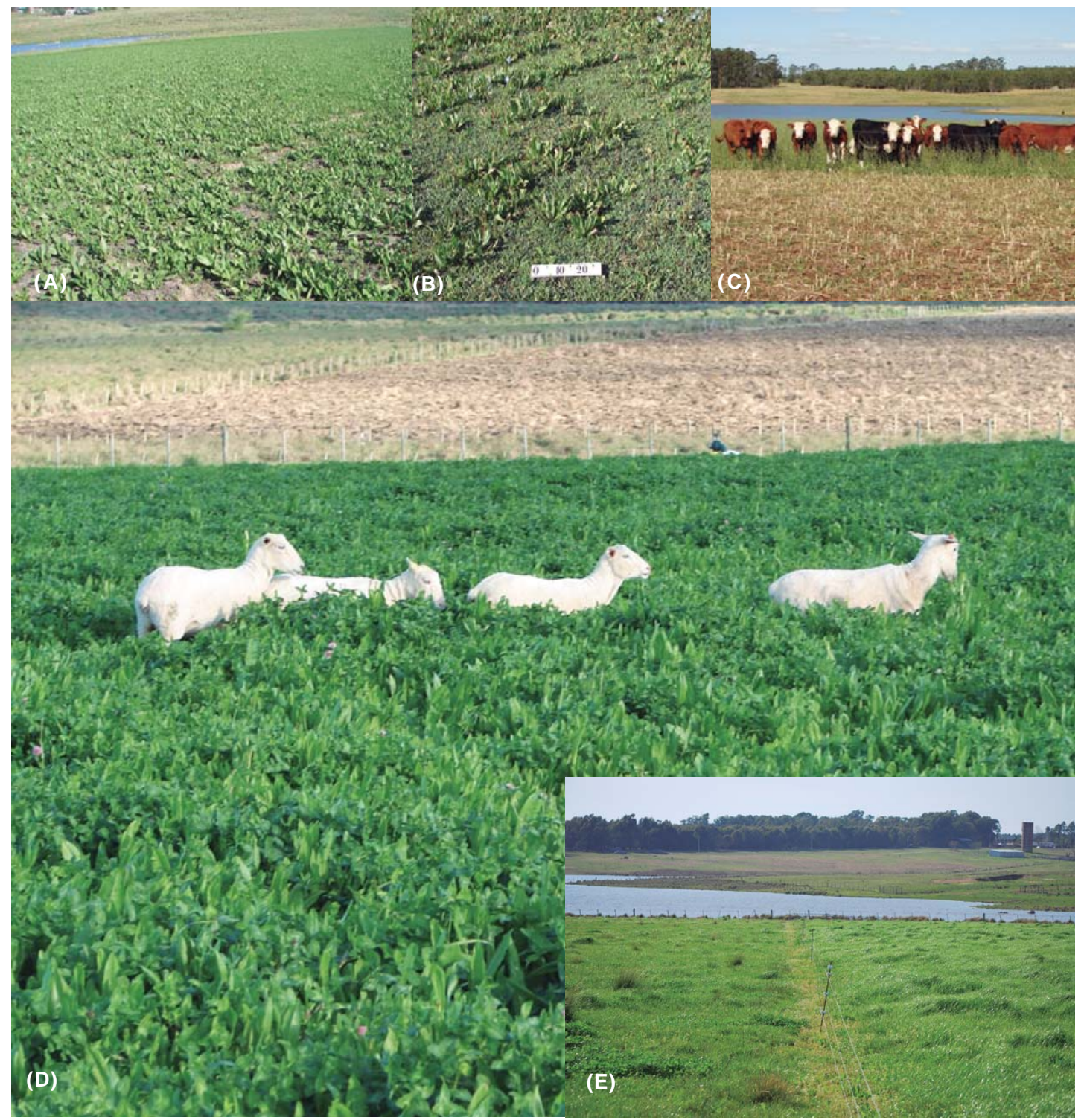

Figura 2. Instalación de la pastura en 2010 (A), invasión de «pasto blanco» en el verano 201011 (B), ingreso de bovinos para control de la floración de Achicoria (C), periodo de máxima producción de la mezcla en primavera 2011 (D), estado actual de la pastura con invasión de raigrás criollo (E).

los pastoreos siguientes se realizaron con bovinos, intentando revertir el proceso. El procedimiento resultó exitoso, registrándose un progresivo incremento de Lotus Makú en toda el área, formándose una entramada asociación con la festuca dado que ambas especies poseen rizomas (Figura 7).

En la primavera 2013, al igual que lo ocurrido en 2012, se deberá controlar la floración de la festuca por las consecuencias ya expuestas para la mezcla de esta gramínea con Trébol Blanco (Figura 8).

\section{Lotus Makú}

En esta pastura se respetó el proceso de formación de rizomas evitando los pastoreos durante el primer otoño luego de la siembra. Por consiguiente, la leguminosa tuvo una excelente implantación, generando elevados volúmenes de forraje (Figura 9). 
Figura 3. Evolución de la cobertura/abundancia de las especies sembradas.

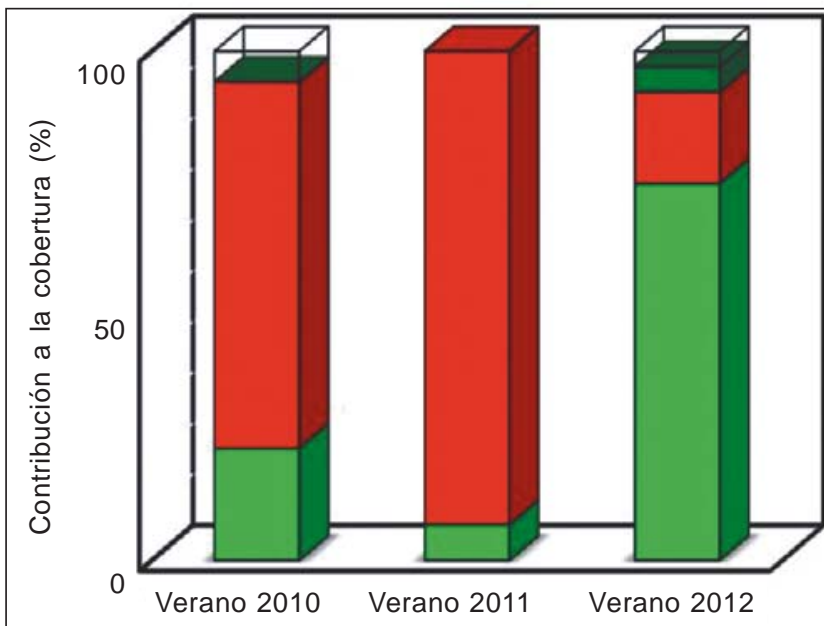

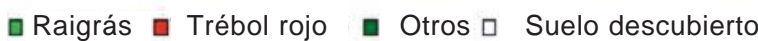

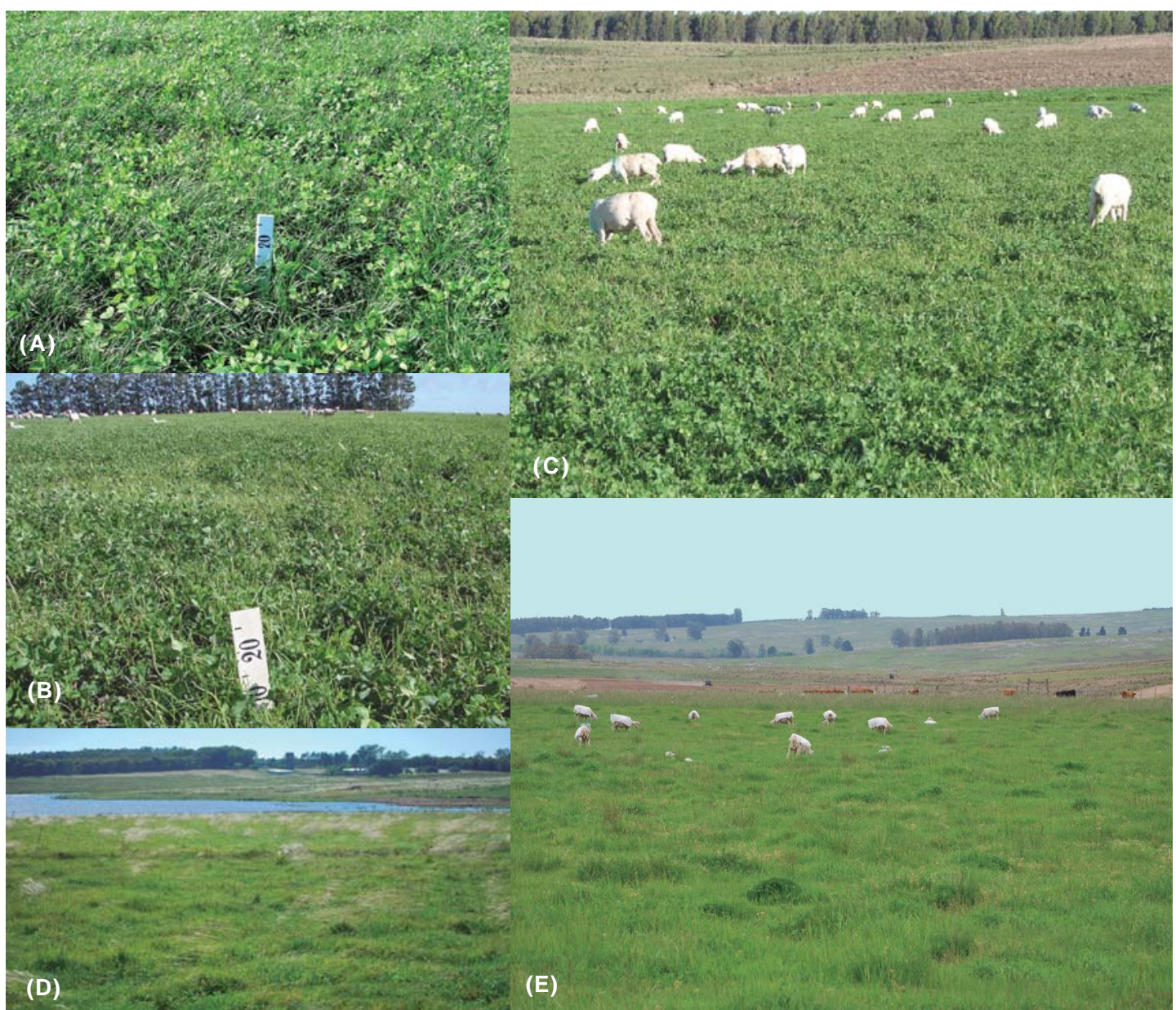

Figura 4. Instalación de la pastura durante primavera-verano de 2010 (A), periodo de máxima producción de forraje (primavera 2011) y pastoreo con altas cargas ovinas (B y C), comienzo de la invasión de especies campestres (Stipa charruana) y retroceso de las pasturas sembradas (D), estado actual de la pasturas con predominio de raigrás criollo, manchones de gramilla y Trébol blanco entremezclado con Trébol rojo (E). 


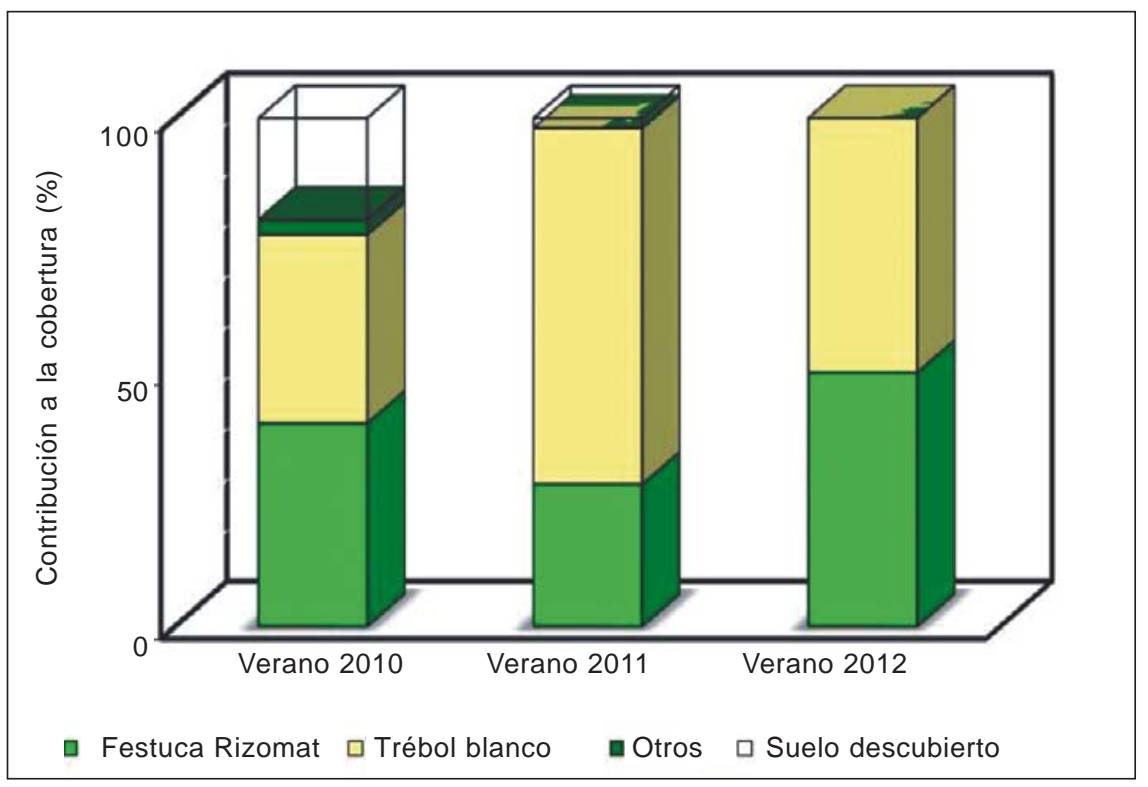

Figura 5. Evolución de la cobertura/abundancia de las especies sembradas.

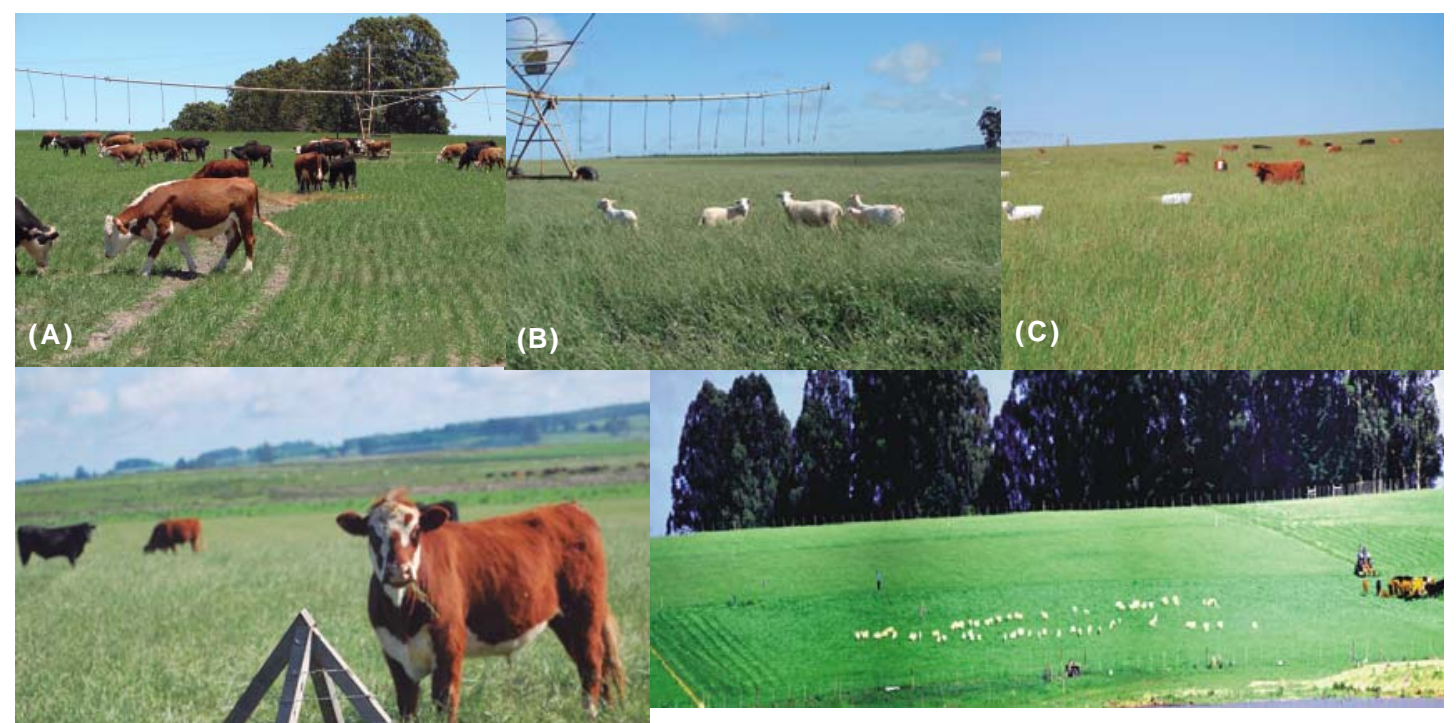

Figura 6. Pastoreo con bovinos durante la instalación de la Festuca en primavera-verano 2010-2011 para reducir la intracompetencia $(A)$, floración primaveral de la festuca en 2011 y 2013 (B y C), presencia de Trébol blanco en las jaulas de corte como consecuencia de la homogenización previa del tapiz, contrastando con el área pastoreada donde domina la festuca (D), control de la floración en la primavera de 2012 (E). 


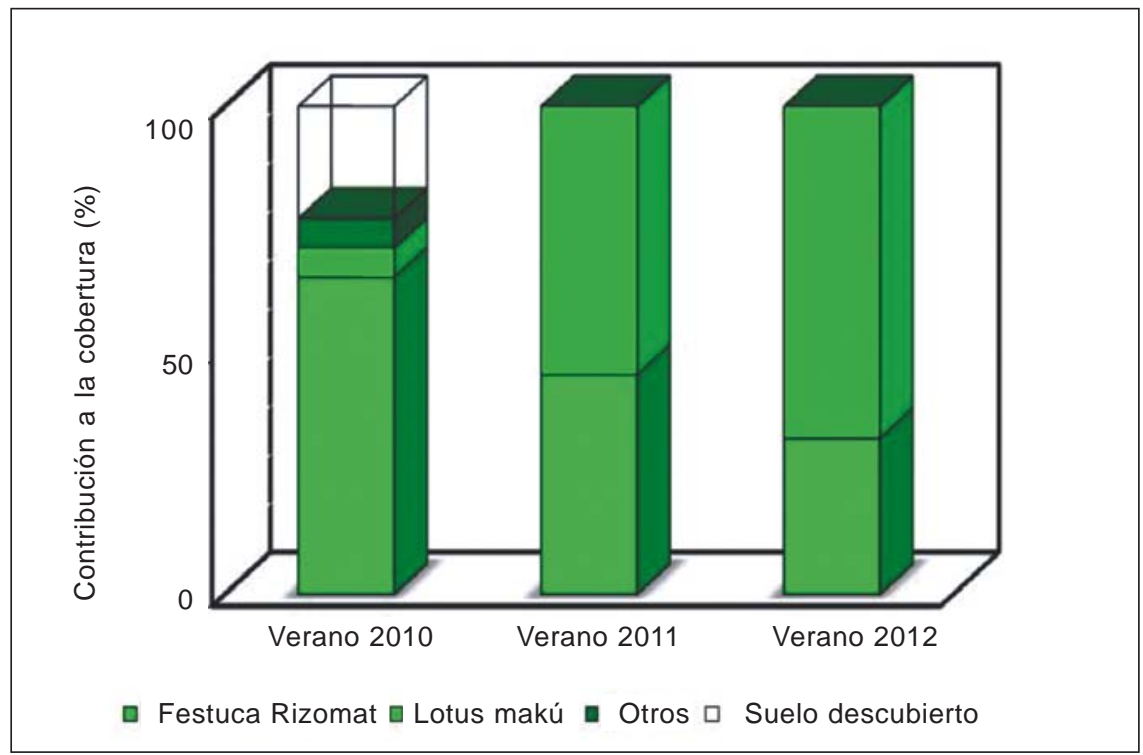

Figura 7. Evolución de la cobertura/abundancia de las especies sembradas.
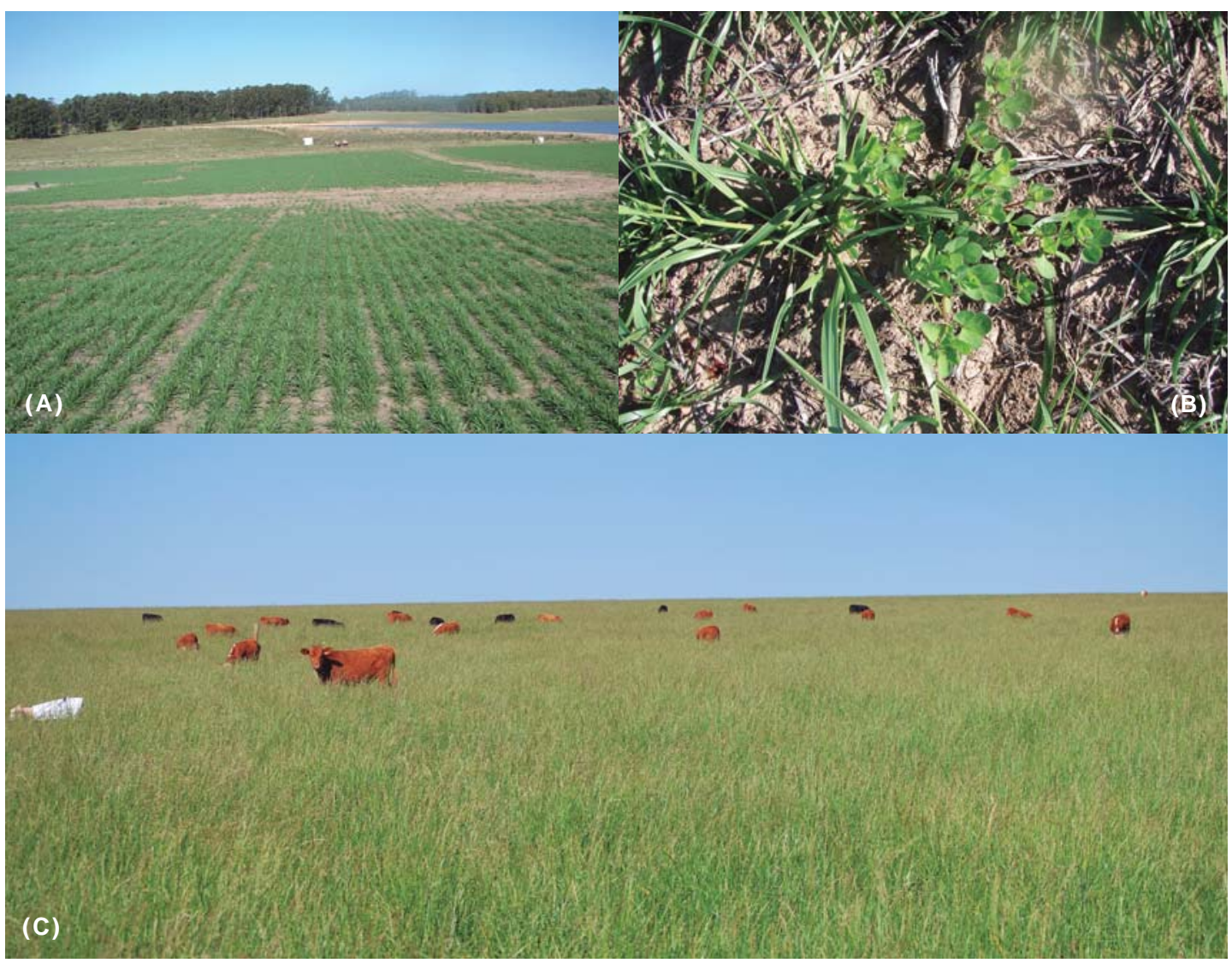

Figura 8. Instalación de la mezcla en la primavera 2010 (A), crecimiento de ambas especies en la línea (B), primavera de 2013 donde ingresaron terneros a pastorear para controlar la festuca y corderos para la leguminosa (C). 


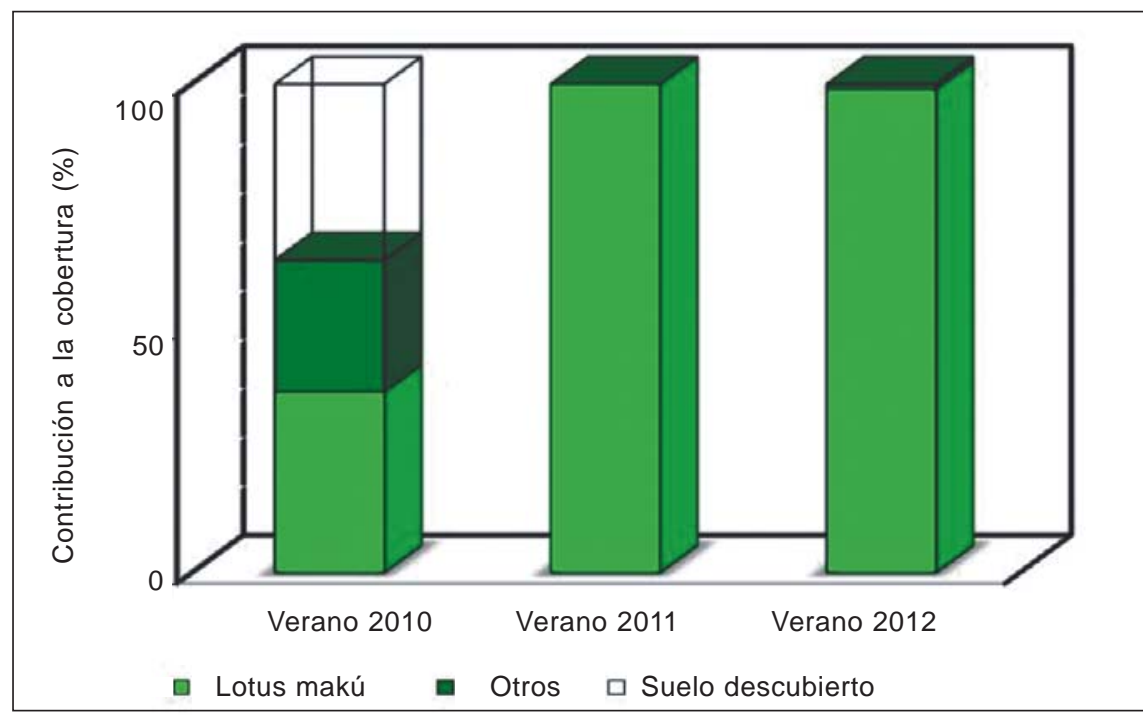

Figura 9. Evolución de la cobertura/abundancia de las especies sembradas.

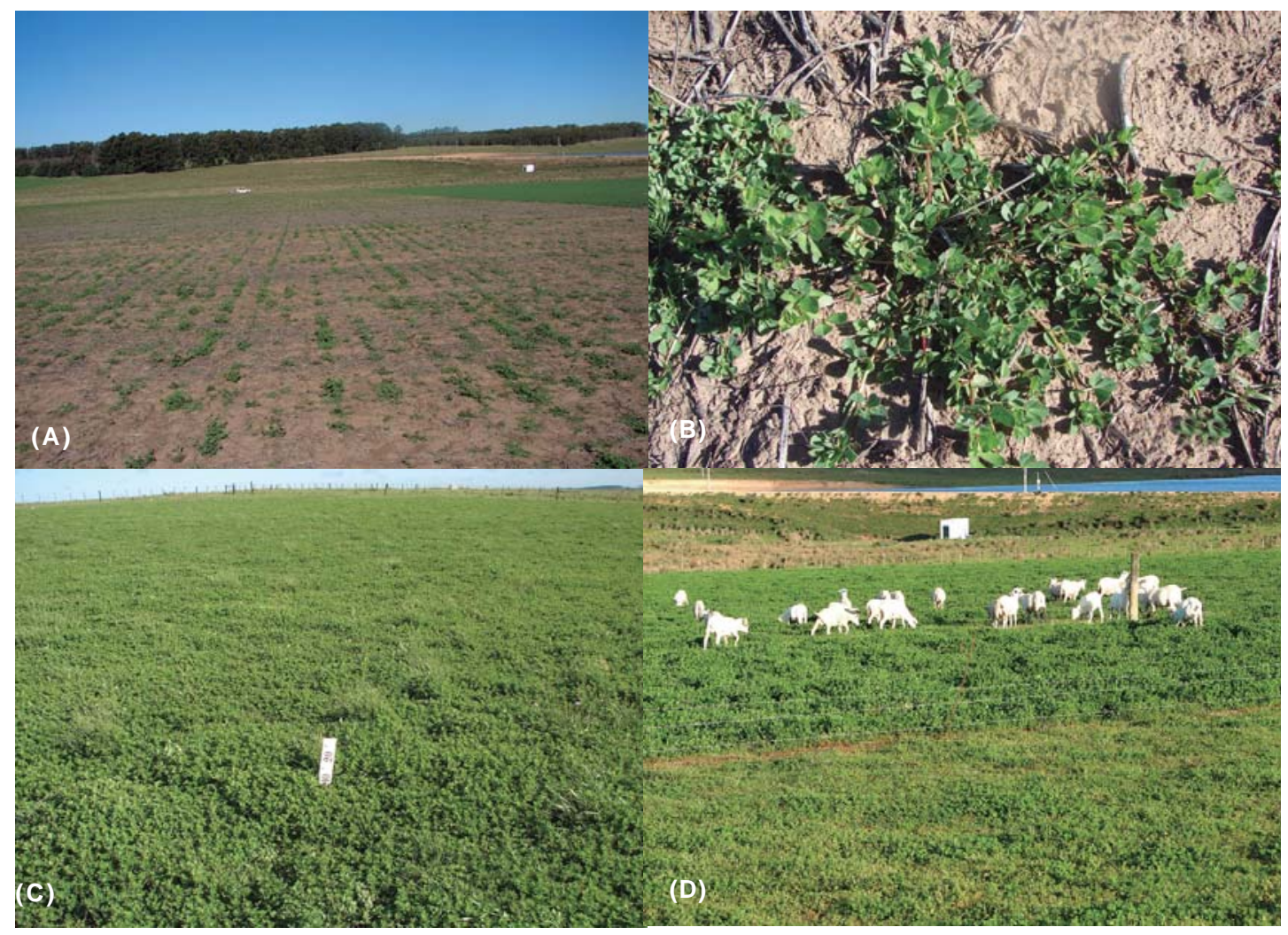

Figura 10. Instalación de la leguminosa sembrada en directa (A), proceso de formación de los órganos de sobrevivencia (rizomas) y cobertura del suelo (estolones) (B), implantación exitosa del L. Makú como cultivo luego de permitir su floración en verano 20102011 (C), pastoreo de altas cargas ovinas en primavera-verano con descanso de otoño (D). 
En este invierno 2013, comenzó la aparición de gramíneas anuales invernales (raigrás criollo, Gaudinia fragilis y Poa annua) así como matas de espartillo (Stipa charruana) mostrando el comienzo de una sucesión secundaria hacia el ambiente original (Figura 11).

Es probable que se requiera algún tipo de intervención (mecánica, química o la combinación de ambas) para detener o enlentecer el proceso. Antes de optar por alguna de estas opciones, ingresaron terneros para que cosechen las gramíneas anuales evitando la competencia que podrían realizar a la leguminosa.

\section{Análisis Económico}

El Ing. Agr. Carlos Salgado realizó una evaluación económica de los sistemas de riego por aspersión instalados en el SUL, con los resultados obtenidos en el año 2012.

De acuerdo con este análisis el autor resume las siguientes consideraciones:

* En el proyecto de riego en CIEDAG, los costos fijos (amortización y mantenimiento) se ubicaron en $168 \mathrm{U} \$ \mathrm{~S} / \mathrm{ha}$.

Los costos variables son el principal componente del costo total, por lo que este tiene alta variabilidad. El costo del kW tiene particular incidencia en esa variabilidad. El promedio del kW en 2012 fue de $\$ 11,21$.
* El costo total del $\mathrm{mm}$ de riego aplicado se situó entre U\$S 1,36 y 2,98.

* El costo por hectárea regada vario entre U\$S 489 y 678 , según sistema de riego y $\mathrm{mm}$ aplicados.

* En los casos analizados los costos de la pastura con riego estuvieron entre 596 y 847 U\$S/ha.

* El Margen Bruto por hectárea para una invernada de lotus Maku bajo riego y con una producción de $1013 \mathrm{~kg}$ de peso vivo de corderos, fue de 1035 U\$S/ha a precios actuales y con un costo de pastura y riego de 717 U\$S/ha.

\section{CONSIDERACIONES FINALES}

La tecnología del riego se presenta al usuario con un sólido protocolo de desarrollo con el cual se pueden realizar cálculos a priori de su posible impacto en las empresas agropecuarias. Sin embargo, cuando se concreta su instalación, surgen una serie de detalles prácticos o imponderables que difícilmente puedan ser contemplados en los correspondientes manuales.

En primer lugar, la variabilidad climática (que en gran medida es la que se pretende amortiguar) no tiene esperas administrativas. En CIEDAG, durante la temporada de riego 2010-2011, las precipitaciones fueron notoriamente inferiores al promedio histórico lo que provocó desfasajes importantes entre las

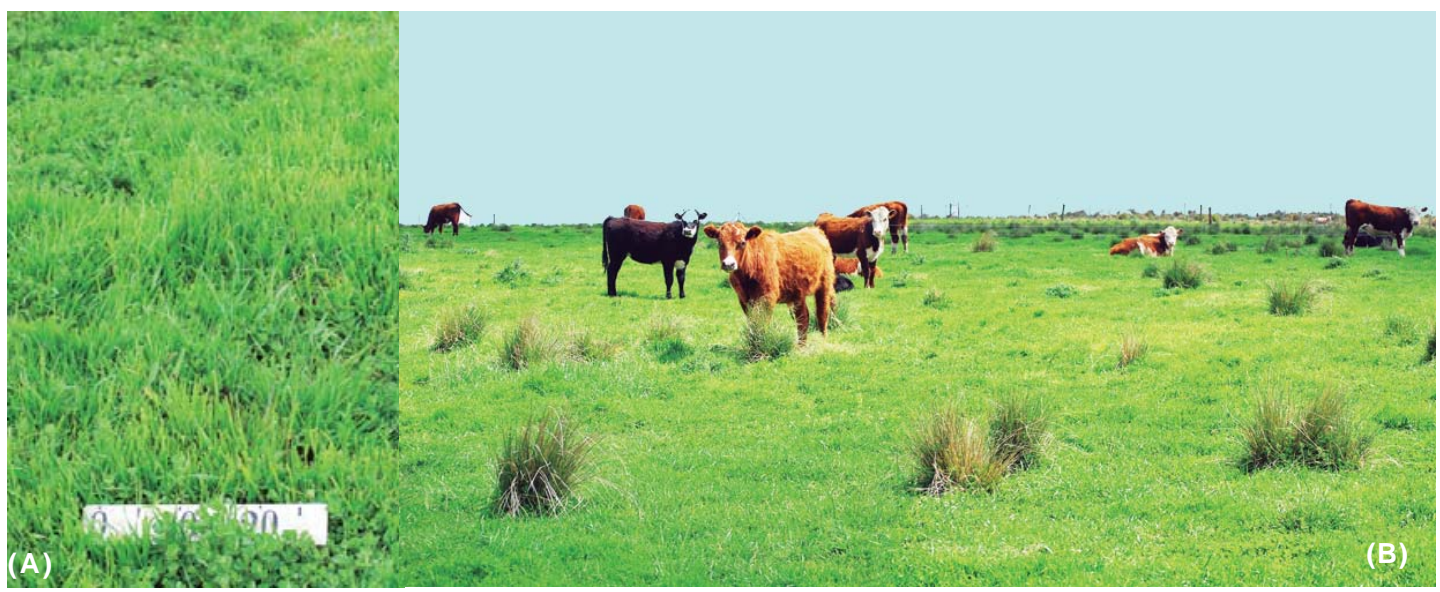

Figura 11. Manchones de Gaudinia fragilis (A), ingreso de terneros para controlar la gramínea invernal y permitir el rebrote de la leguminosa en primavera (B). 
necesidades hídricas de las pasturas y la respuesta del sistema.

El viento también afecta a la homogeneidad del riego. Aunque no existe ningún análisis disponible sobre este punto, puede decirse que el sistema irripod es el más afectado por este factor, lo que se traduce en rendimiento desigual de las pasturas o cultivos que se encuentren instalados. Además, el movimiento de las líneas de este sistema necesita de un vehículo de cierta potencia que debe ser considerado en los costos, dado que está propuesto para productores pequeños por el menor costo de inversión por hectárea.

En segundo lugar, un periodo de aprendizaje de la rutina del riego y su logística a la que se agrega la rotura de caños y conexiones, puede retrasar el uso corriente del riego durante periodos altamente sensibles para la viabilidad de las pasturas como la siembras de primavera de especies templadas.

Estos inconvenientes se suscitaron en la primera temporada de aplicación de los diferentes sistemas, lo que implicó tener un déficit hídrico en las pasturas durante ciertos períodos.

El sitio de implementación del riego puede condicionar indirectamente la fluidez de la operatividad del sistema. Por ejemplo, en áreas alejadas de centros poblados con representación en repuestos, a pesar de la buena disposición de las empresas proveedoras de insumos.

En cuanto a las pasturas que se riegan, si bien hay una respuesta destacable de los cultivares forrajeros, también la hay en aquellas especies consideradas malezas (pasto blanco, gramilla) que tienden a ocupar rápidamente los espacios que dejan las anteriores. Por consiguiente, no debería esperarse una estabilidad adicional de las leguminosas integrantes de una mezcla forrajera por el hecho de ser regadas, sino un aumento de su producción en periodos similares a su comportamiento en secano pero con una sobrevivencia en verano que permite por ejemplo, que el trébol blanco se comporte como planta perenne y no sea necesario un cierre riguroso para semillazón.

\section{AGRADECIMIENTOS}

Al Ing.Agr. Francisco Preve, encargado del desarrollo del Proyecto Riego del SUL durante el primer año de su ejecución.

\section{BIBLIOGRAFÍA}

CREMPIEN, C. 1978. Antecedentes Técnicos y Metodología Básica para utilizar en Presupuestación en Establecimientos Ganaderos. Hemisferio Sur. Montevideo. $72 p p$.

CRESPO, R.J.; CASTAÑO, J.A.; CAPURRO, J.A. 2007. Secado de Forraje con el horno microondas: efecto sobre el análisis de calidad. Agricultura Técnica 67(2): 210-218.

DUHALDE, J.M. 2001. Riego y fertilización de una pastura base alfalfa del centro sur bonaerense. INTA.

FORMOSO D.; FERNÁNDEZ ABELLA D.; BOGGIANO P.; AQUINO C.; CONDE A. 2013. Efecto de la intensidad de cosecha en la producción y estabilidad de pasturas sembradas. INIA. Serie Técnica 208. 35-46.

FORMOSO, F. 2007. Producción de Forraje con Riego. Seminario sobre Riego, Paysandú.

GIORELLO, D.; JAURENA, M.; BOGGIANO, P.; PEREZ GOMAR, E. 2012. Respuesta al Riego Suplementario en Pasturas y Forrajes.Riego en Cultivos.

PÉREZ GOMAR, E.; SILVEIRA. 2009. Riego en Suelos de Basalto. Efectos de la Sequía: acciones realizadas y Propuestas Otoño-Invernales. INIA. Glencoe, Día de Campo: 1-4.

PETRUZZI, H.J.; STRIZLER, N.P.; FERRI, C.M.; PAGELLA, J.H.; RABOTNIKOF, C.M. 2005. Determinación de Materia Seca por métodos indirectos: utilización del horno a microondas. INTA. Boletín de Divulgación Técnica 88: 8-11.

SAWCHIK, J. 2012. Necesidades de Riego en Cultivos y Pasturas. Riego en Cultivos y Pasturas. $2^{\circ}$ Seminario Internacional. Salto:57-68. 
SCHIRIPIA, L.; VERNENGO, E.; PARIANI, S. 1995. Efecto del riego complementario sobre la producción de forraje de leguminosas perennes de clima templado. Revista Argentina de Producción Animal 15(1). $2 \mathrm{p}$.
VOLESKY, J.D.; ANDERSON, B.; NICHOLS, J.T. 2003. Perennial Forages for Irrigated Pasture. NebGuide, University of Nebraska. 


\title{
ALTERNATIVAS GENÉTICAS PARA
} MEJORAR LA PRODUCCIÓN Y CALIDAD DEL PRODUCTO CARNE OVINA

\section{RESUMEN}

\begin{abstract}
En el presente trabajo, se estudian herramientas que permiten la mejora entre (cruzamientos) y dentro de raza (evaluaciones genéticas). Se presentan tres artículos independientes entre sí: (I) Evaluaciones genéticas de razas carniceras en el Uruguay; (II) Heredabilidades de características de calidad de carne y la canal en la raza Texel; y (III) Diferencias en pesos al nacimiento y destete entre las razas Corriedale y Texel. De estos trabajos se puede resumir: I. Se observan importantes diferencias genéticas entre los animales evaluados de las razas Hampshire, Poll Dorset y Texel para las distintas características. Los progresos genéticos en la raza Texel fueron de 0,65 y 1,37 \% anual para los pesos al destete y a la recría, respectivamente. En la cabaña de mayor progreso estos valores fueron de 2,2 y $2,7 \%$ anual, respectivamente. II. Las heredabilidades para las características de calidad de canal y de la carne presentaron una magnitud de moderada a alta, oscilando entre valores de 0,26 y 0,83. Sin embargo estos resultados son preliminares y presentan amplios intervalos de credibilidad (95\%HPD). III. Los beneficios del cruzamiento entre una raza terminal (Texel) y una doble propósito (Corriedale) en $\mathrm{kg}$ al destete, estuvieron dados principalmente por el efecto aditivo directo (14\%). En menor medida el cruzamiento fue beneficiado por el efecto aditivo maternal (5\%) de la raza terminal y la heterosis individual (2\%), aunque estos parámetros no fueron significativos $(P>0,05)$. Ambas herramientas presentadas son complementarias y correctamente combinadas permitirían aumentar el beneficio económico del productor.
\end{abstract}

Palabras clave: cruzamientos, Hampshire Down, Poll Dorset, Texel, Uruguay

\section{INTRODUCCIÓN GENERAL}

La producción ovina ha conformado históricamente una de las actividades de mayor importancia económica para el Uruguay. Actualmente, existen 21093 predios que crían ovinos en Uruguay, representando 41\% del total de productores ganaderos. De éstos, el 70\% (14732) poseen al menos 50 lanares y el $94 \%$ los cría junto con vacunos (DICOSE, 2012). Estos establecimientos mantienen 8.2 millones de ovinos, de los cuales $52 \%$ son ovejas de cría (encarneradas), que componen las existencias de esta especie en el país (DICOSE, 2012). Tradicionalmente, la lana ha sido el principal producto del rubro. Sin embargo, en los últimos años la importancia de la producción de cor- deros ha crecido significativamente. El cordero pesado surge a mediados de los 90 como un alternativa productiva de importancia, complementando y en muchos casos superando en competitividad a la producción de lana; consolidándose tanto la producción de carne como la corriente comercial exportadora de canales y cortes de corderos (Azzarini, 2000; Ganzábal y col., 2007).

En la actualidad diferentes proyectos relacionados con la mejora genética de la producción y calidad de la carne ovina son llevados a cabo por INIA en estrecha colaboración con diferentes instituciones: Secretariado Uruguayo de la Lana (SUL), Facultad de Agronomía (FAgro) y de Veterinaria (FVet) de la Universidad de la República, Sociedad de Criadores Texel del Uruguay (SCTU). 
A continuación se presentan los diferentes grupos de trabajo según enfoque:

1. Evaluaciones Genéticas: Gabriel Ciappesoni (INIA), Diego Gimeno (SUL), Fernando Coronel (SUL), Pablo Balduvino (SUL), Leonardo Raimondo (SUL).

2. Carne de calidad Texel (Centro de Conexiones Texel): Gustavo Brito (INIA), Gabriel Ciappesoni (INIA), Roberto San Julián (INIA), Elly Navajas (INIA), Pablo Peraza (INIA), Virginia Goldberg (INIA), Eillen Armstrong (FVet.), Wanda Iriarte (FVet.), Silvina Pereira (FVet.), Diego Gimeno (SUL), Pedro Screminni (SUL), Eduardo Lucas (SCTU).

3. Cruzamientos: a) Dialélico Texel $x$ Corriedale (INIA La Estanzuela): Georgett Banchero (INIA), Andrés Vázquez (INIA), Gabriel Ciappesoni (INIA), Roberto San Julián (INIA).

b) Cruzamientos Texel x Corriedale (Estación Experimental Prof. Bernardo Rosengurtt - FAgro): Jorge Urioste (FAgro), Raúl Ponzoni (FAgro), Carlos Mantero (FAgro), Fernando Pereyra (FAgro), Ana Laura Sánchez (FAgro), Gabriel Ciappesoni (INIA),
Diego Gimeno (SUL), Eduardo Lucas (SCTU), Vinicio Mazzei (SCTU).

Algunos de estos enfoques llevan varios años de trabajo (ej. Evaluaciones genéticas) y otros como el proyecto «Cruzamientos Texel x Corriedale» liderado por Facultad de Agronomía se encuentra en su primer año de desarrollo. A continuación se presentarán tres artículos que reflejan el trabajo dentro de estos diferentes enfoques, que si bien son independientes entre sí, contribuyen a un objetivo en común que será analizado en las conclusiones finales:

I. Evaluaciones genéticas de razas carniceras en el Uruguay

Ciappesoni, G.; Gimeno, D.; Coronel F.

II. Heredabilidades de características de calidad de carne y la canal en la raza Texel

Ciappesoni, G.; San Julián, R.; Brito, G.; Gimeno, D.; Navajas, E.A; Goldberg, V.

III. Diferencias en pesos al nacimiento y destete entre las razas Corriedale y Texel

Ciappesoni, G.; Vázquez, A.; Banchero, G. 


\title{
I. EVALUACIONES GENÉTICAS DE RAZAS CARNICERAS EN EL URUGUAY
}

\author{
Ciappesoni, G. ${ }^{1}$; Gimeno, D. ${ }^{2}$; Coronel F. ${ }^{2}$ \\ ${ }^{1}$ Instituto nacional de Investigación Agropecuaria (INIA) \\ ${ }^{2}$ Secretariado Uruguayo de la Lana (SUL)
}

\section{INTRODUCCIÓN}

Los cabañeros y productores uruguayos cuentan con las Evaluaciones Genéticas Poblacionales (EGP) realizadas por el INIA y el Secretariado Uruguayo de la Lana (SUL), para la mejora genética de las razas: Corriedale, Frisona Milchschaf, Hampshire Down, Ideal, Merilin, Merino Australiano, Romney Marsh y Texel. Asimismo, se realizan evaluaciones intramajada de Highlander, Poll Dorset, y Merino Dohne, y de las majadas experimentales de INIA (Merino Dohne y Finnsheep). En total se evalúan 20 características, presentándose dichos valorescomo Diferencias Esperadas en la Progenie (DEP, www.geneticaovina.com.uy). En los últimos 10 años, se incrementó en número de cabañas de 11 a 86, y en nuevos animales evaluados anualmente de 3740 a 25259 . Se incluyen características relacionadas con la producción y calidad de carne y lana, reproducción y resistencia a parásitos gastrointestinales (PGI). La Texel fue la primera raza carnicera en realizar evaluaciones genéticas en el Uruguay, comenzando con la generación 2008. Previamente, el INIA junto a la Sociedad de Criadores de Texel del Uruguay (SCTU), habían desarrollado una evaluación intramajada de las generaciones 2005 a 2007 de tres cabañas. Actualmente, son siete las cabañas participantes de la EGP de la raza, ingresando aproximadamente 1000 animales nuevos cada año. Una cabaña Poll Dorset y una Hampshire Down comenzaron con la evaluación genética intramajada con la generación 2011. En esta última, se prevé para la generación 2013 contar con una EGP de tres cabañas.

El objetivo del presente trabajo fue analizar las evaluaciones genéticas de las razas Hampshire, Poll Dorset y Texel en el Uruguay, en cuanto a número de animales eva- luados, promedios fenotípicos y percentiles. Para la raza Texel se estudió además el progreso genético logrado.

\section{MATERIALES Y MÉTODOS}

La evaluación genética se realizó con un modelo animal multivariado con el programa BLUPF90 (Misztal et al., 2002). Se evaluaron conjuntamente las características relacionadas con crecimiento y las mediciones de ultrasonografía: peso vivo al nacimiento (PND), al destete (PDD), a la recría (PRD, coincide con el momento de la ultrasonografía), área del ojo de bife (AOB) y espesor de grasa sobre este (EG). La mayor parte de los datos (productivos y genealógicos) son registrados por los propios cabañeros e ingresados a la base de datos por medio del software «SULAR - Módulo del Productor», desarrollado por el SUL en el 2004. Asimismo, a esta base se le adjuntan datos provenientes de las mediciones de ultrasonido in vivo realizadas por técnicos de INIA (i.e. AOB y EG). La información genealógica de los animales pedigrí es enviada y controlada por la Asociación Rural del Uruguay (ARU). El modelo utilizado fue el empleado rutinariamente en las evaluaciones genéticas:

$$
y_{i j k l}=G C_{i}+T N_{j}+E M_{k}+a ̂ x_{i j k l}+a_{1}+e_{i j k l}
$$

Donde:

$\mathrm{y}_{\mathrm{ijkl}}$ es la característica evaluada, los efectos sistemáticos son: $\mathrm{GC}_{i}$ grupo contemporáneo i (definido como sexo-cabaña-año-grupo de manejo), $\mathrm{TN}_{\mathrm{j}}$ tipo de nacimiento j (2 niveles: único y múltiple), $\mathrm{EM}_{\mathrm{k}}$ edad $\mathrm{k}$ de la madre (3 niveles: $2,3 y \geq 4$ años), $x_{\mathrm{j} j \mathrm{kl}}$ es la edad del cordero en días a la medición correspondiente siendo â la covariable (este efecto no se incluye al evaluar PND); $a_{1}$ es el efecto genético aditivo del animal $\mathrm{l}, \mathrm{y}_{\mathrm{ijkl}}$ es el resi- 
duo aleatorio del modelo. El sexo se incluye dentro del GC ya que la mayoría de los animales luego del destete se maneja en forma separada por sexo. El grupo de manejo dentro del GC, incluye todos los lotes previos en los que estuvo el animal desde el nacimiento, según corresponda para cada característica. Se calcularon los percentiles por raza mediante el procedimiento Univariate del paquete estadístico SAS (Statistical Analysis System, Version 9.2, 2008). Para la raza Texel se calculó la ganancia genética como la diferencia entre el valor genético de la progenie 2012 con respecto a la primera generación evaluada (año 2008). Se expresó como ganancia anual en porcentaje respecto a la media fenotípica poblacional de la característica.

\section{RESULTADOS Y DISCUSIÓN}

En el Cuadro 1, se presenta la estadística descriptiva de los datos utilizados en las evaluaciones genéticas de las razas carniceras. Se observan importantes coeficientes de variación (CV) en las mediciones, por ejemplo para PRD este valor es de 21, 29 y $22 \%$ para las razas Hampshire, Poll Dorset y Texel, respectivamente. Los mayores CV son para las mediciones de ultrasonido, siendo estas del orden del $30 \%$ para AOB y de $45 \%$ para EG. Estas amplias variaciones se deben a que los datos son registrados en diferentes cabañas, años, lotes de manejo, sexos y en animales nacidos como únicos y mellizos y de ovejas con diferentes edades. Todos estos efectos son tenidos en cuenta al momento de realizarse las evaluaciones genéticas para la estimación de las DEP. Asimismo, en el caso del EG es de esperar que dado los bajos promedios obtenidos, el error de la medición afecte en mayor medida al registro de esta característica.

En el Cuadro 2, se presentan los percentiles para los pesos al destete y a la recría para las tres razas estudiadas. Estos datos se presentan en forma rutinaria en los catálogos de padres (www.geneticaovina.com.uy) y los diversos remates de cabaña, con el fin de facilitar la elección de los reproductores por parte de los potenciales compradores. Las evaluaciones genéticas permiten detectar diferencias en el potencial desempeño de los animales y sus hijos. De esta forma, la diferencia en el desempeño de la progenie de un carnero ubicado en el $1 \%$ superior para PRD versus un carnero promedio (50\%) es de 2,3, 3,3 y $2,5 \mathrm{~kg}$ para las razas Hampshire, Poll Dorset y Texel, respectivamente. Asimismo, las diferencias en PRD entre un carnero $5 \%$ vs. uno $95 \%$ es de $2,8,4,7$ y 3,3 $\mathrm{kg}$ respectivamente. En el caso de PDD, las diferencias entre animales ubicados en el $1 \%$ superior y el $50 \%$ (promedios) son de 2,31 , 1,82 y $1,74 \mathrm{~kg}$ para Hampshire, Poll Dorset y Texel, respectivamente. Estos valores indican la ventaja que ofrece para los compradores de genética el poder adquirir un pro-

Cuadro 1. Estadística descriptiva de las principales características registradas (n: número de registros, x: media, d.s.: desvío estándar) en las evaluaciones genéticas de las razas carniceras.

\begin{tabular}{|c|c|c|c|c|c|c|c|c|c|}
\hline & \multicolumn{3}{|c|}{ Hampshire Down } & \multicolumn{3}{|c|}{ Poll Dorset } & \multicolumn{3}{|c|}{ Texel } \\
\hline & $\mathbf{n}$ & $\mathbf{x}$ & d.s. & $\mathbf{n}$ & $x$ & d.s. & $\mathbf{n}$ & $x$ & d.s. \\
\hline PND kg & 217 & 5,2 & 0,9 & 332 & 4,4 & 0,7 & 3126 & 4,9 & 1,0 \\
\hline Edad Dest. días & 218 & 115,7 & 17,5 & 340 & 99,1 & 18,7 & 4102 & 114,0 & 15,2 \\
\hline PDD kg & 211 & 30,1 & 8,5 & 267 & 34,5 & 7,8 & 3646 & 27,8 & 5,9 \\
\hline Edad Recría* días & 100 & 201,3 & 18,1 & 340 & 252,6 & 19,7 & 3813 & 260,0 & 25,6 \\
\hline PRD kg & 180 & 42,1 & 8,8 & 233 & 50,0 & 14,7 & 3239 & 35,5 & 7,9 \\
\hline AOB $\mathrm{cm}^{2}$ & & & & 233 & 13,4 & 4,1 & 3230 & 9,6 & 3,0 \\
\hline EG mm & & & & 233 & 2,9 & 1,3 & 3230 & 2,5 & 1,1 \\
\hline
\end{tabular}

Nota: Pesos al nacimiento (PND), al destete (PDD) y a la recría (PRD) directos; área del ojo de bife (AOB), espesor de grasa subcutánea (EG). * Las mediciones llamadas «a la recría» coinciden en las razas carniceras con la edad aproximada de faena y es cuando se realiza la medición de ultrasonido. 
Cuadro 2. Percentiles de las DEP para peso al destete (PDD) y a la recría (PRD) directo en las razas carniceras.

\begin{tabular}{|l|l|l|c|c|c|c|}
\hline \multirow{2}{*}{ Referencia } & \multicolumn{2}{|c|}{ Hampshire Down } & \multicolumn{2}{c|}{ Poll Dorset } & \multicolumn{2}{c|}{ Texel } \\
\cline { 2 - 7 } & $\begin{array}{c}\text { DEP PDD } \\
\mathbf{k g}\end{array}$ & $\begin{array}{c}\text { DEP PRD } \\
\mathbf{k g}\end{array}$ & $\begin{array}{c}\text { DEP PDD } \\
\mathbf{k g}\end{array}$ & $\begin{array}{c}\text { DEP PRD } \\
\mathbf{k g}\end{array}$ & $\begin{array}{c}\text { DEP PDD } \\
\mathbf{k g}\end{array}$ & $\begin{array}{c}\text { DEP PRD } \\
\mathbf{k g}\end{array}$ \\
\hline Máximo & 2,91 & 2,94 & 3,13 & 6,11 & 3,02 & 5,87 \\
$\mathbf{1 \%}$ & 2,56 & 2,56 & 2,2 & 3,65 & 1,72 & 2,75 \\
$\mathbf{5 \%}$ & 1,71 & 1,71 & 1,60 & 2,33 & 1,17 & 1,91 \\
$\mathbf{1 0 \%}$ & 1,41 & 1,43 & 1,26 & 1,89 & 0,89 & 1,49 \\
$\mathbf{2 5 \%}$ & 0,79 & 0,8 & 0,82 & 1,10 & 0,42 & 0,84 \\
$\mathbf{5 0} \%$ & 0,25 & 0,26 & 0,38 & 0,36 & $-0,02$ & 0,21 \\
$\mathbf{7 5 \%}$ & $-0,30$ & $-0,30$ & $-0,31$ & $-0,48$ & $-0,37$ & $-0,36$ \\
$\mathbf{9 0} \%$ & $-0,87$ & $-0,88$ & $-1,00$ & $-1,50$ & $-0,75$ & $-0,97$ \\
$\mathbf{9 5 \%}$ & $-1,04$ & $-1,04$ & $-1,48$ & $-2,36$ & $-1,00$ & $-1,38$ \\
$\mathbf{9 9 \%}$ & $-1,54$ & $-1,56$ & $-2,12$ & $-3,45$ & $-1,43$ & $-2,06$ \\
Mínimo & $-2,15$ & $-2,18$ & $-2,47$ & $-4,81$ & $-2,10$ & $-3,49$ \\
\hline
\end{tabular}

Nota: Diferencia esperada en la Progenie (DEP) de Pesos al destete (PDD) y a la recría (PRD) directos.

ducto que además de contar con un diferencial racial (por ser razas seleccionadas por un mayor crecimiento), en el caso de usarse en cruzamientos, disponer de una evaluación objetiva del potencial de mejora dentro de la propia raza.

El progreso genético logrado en la raza Texel se refiere a sólo cinco generaciones donde, dado el intervalo generacional, la primera vez que los cabañeros pudieron contar con la evaluación genética fue al seleccionar los padres de la tercera generación. Sin embargo, algunas cabañas Texel, además, contaron con la evaluación de PDD ya para la selección de los padres de la segunda generación. Las ganancias genéticas anuales (expresadas en porcentaje de la media fenotípica poblacional del Cuadro 1), fueron de 0,60 (PND), 0,65 (PDD), 1,37 (PRD), 0,35 $(A O B)$ y 0,42 (EG) \%. Estas reflejan los objetivos de selección que en forma general ha aplicado la raza, sin embargo cada cabaña tiene diferentes énfasis en las características a seleccionar dependiendo de sus objetivos. Los valores máximos de ganancia genética en el periodo de cinco años (generaciones 2008 al 2012) por cabaña individual fueron de $1,8 \mathrm{~kg}, 2,9 \mathrm{~kg}$ y $0,56 \mathrm{~cm}^{2}$, para PDD, PRD y AOB, respectivamente. Estos valores corresponden a 2,2, 2,7 y 2,0\% de progreso genético anual. Si en general se considera, que el progreso genético potencial al seleccionar sólo por una característica determinada dentro de un núcleo de selección ronda el $2 \%$ anual, se puede concluir que los progresos genéticos obtenidos son muy considerables. 


\title{
II. HEREDABILIDADES DE CARACTERÍSTICAS DE CALIDAD DE CARNE Y LA CANAL EN LA RAZA TEXEL
}

\author{
Ciappesoni, G. ${ }^{1}$; San Julián, R. $^{1}$; Brito, G. ${ }^{1}$; Gimeno, D. ${ }^{2}$; \\ Navajas, E.A. ${ }^{1}$; Goldberg, ${ }^{1}{ }^{1}$
}

${ }^{1}$ Instituto nacional de Investigación Agropecuaria (INIA). ${ }^{2}$ Secretariado Uruguayo de la Lana (SUL).

\section{INTRODUCCIÓN}

En el año 2008 la Sociedad de Criadores Texel del Uruguay (SCTU) decide formar una central de prueba de progenie con el fin de facilitar la conexión entre cabañas interesadas en participar en una Evaluación Genética Poblacional (EGP) (Ciappesoni y Gimeno, 2012). Es así que surge el centro de conexiones Texel (CCT) en el establecimiento «La Aripuca» de Don José Alcides Lucas en las proximidades de Tupambaé. Cada una de las cabañas participantes tiene la posibilidad de enviar un carnero que trabajará a su vez en su cabaña el mismo año, con la finalidad de lograr la conexión entre los predios (Ciappesoni y Gimeno, 2012). A todos los animales (machos y hembras) nacidos en la CCT, se les extrae sangre para realizar la extracción de ADN, conservándose en el Banco de ADN Genómico Animal de INIA Las Brujas. Los corderos machos, luego de participar en la EGP, son enviados a frigorífico donde se les realiza mediciones post-morten relacionadas con la calidad de la canal y la carne, bajo el liderazgo de técnicos especialistas de INIA Tacuarembó. La CCT se ha convertido en una plataforma para la investigación así como para la difusión de las herramientas genéticas y de nuevas tecnologías. Ejemplo de esto, es el recientemente finalizado proyecto INNOVAGRO «Asociación de SNP de genes candidatos con caracteres de calidad de la carne y la canal en ovinos», liderado por Facultad de Veterinaria (Universidad de la República). Asimismo, se han desarrollo diferentes trabajos científicos (Ciappesoni y col., 2012; San Julián y col., 2012) y tesis de grado (Pereira, 2012). La CCT forma parte de la población de entrena- miento para estudios genómicos de características complejas.

El objetivo del estudio fue estimar los parámetros genéticos preliminares de características relacionadas con la calidad de la canal y la carne en la raza Texel.

\section{MATERIALES Y MÉTODOS}

Se analizaron las siguientes características relacionadas con la calidad de la canal: peso de la canal caliente (PCC, $\mathrm{kg}$ ), peso de cortes valiosos: French Rack, (FR, kg), pierna con cuadril sin hueso (Pierna, kg) y paleta corte cuadrado (Paleta, kg); profundidad de los tejidos (GR, cm); medidas morfométricas: largo de la canal (LC, cm), largo $(\mathrm{LP}, \mathrm{cm})$ y perímetro de pierna (PP, $\mathrm{cm})$. Relacionado con la calidad de la carne se evaluaron: terneza $(\mathrm{kgF})$, contenido de grasa intramuscular (\%) y de ácidos grasos saturados (SFA, \%), monoinsaturados (MUFA, $\%$ ) y poliinsaturados (PUFA, \%); color de la carne (Color $a^{*}, b^{*}$ y L*). Los registros de estas características se detallan en San Julián et al. (2012) y Pereira (2012)

La estimación de los componentes de varianzas se realizó mediante metodología bayesiana empleando el programa GIBBS2F90 (Misztal y col., 2002). Se obtuvieron 20.000 muestras de una cadena simple, a partir de 1000000 de iteraciones, descartándose las primeras 600000 (burn-in) y el intervalo entre la toma de muestras fue de 20 ciclos. Se calcularon la media y mediana posterior, el desvío estándar posterior (PSD) y el intervalo de credibilidad más corto con un $95 \%$ de probabilidad de contener el verdadero valor (HPD 95\%) de las distribucio- 
nes posteriores marginales estimadas. El modelo utilizado fue el mismo presentado para las evaluaciones genéticas (ver capítulo anterior: I. Evaluaciones genéticas de razas carniceras en el Uruguay, Ciappesoni, Gimeno y Coronel).

Se evaluaron 276 corderas y corderos faenados entre los años 2009 y 2011, con un promedio de $45 \mathrm{~kg}$ de peso vivo y 3,5 puntos de condición corporal. La genealogía incluyó 670 animales, incluyendo 13 padres y 221 madres.

\section{RESULTADOS Y DISCUSIÓN}

Las estimaciones de las heredabilidades para las características de calidad de canal y de la carne se presentan en el Cuadro 1. Estas fueron de moderada a alta magnitud en concordancia con otros estudios (e.g. Waldron et al., 1992; Cloete et al., 2008). Estos resultados confirman la oportunidad para realizar mejoramiento genético en las características estudiadas. Sin embargo, éstos deben de ser interpretados con precaución debido al reducido número de animales con datos fenotípicos y en la genealogía. Esto se ve reflejado en los amplios intervalos de credibilidad (95\%HPD). En los próximos años se espera poder seguir incrementando el número de animales analizados lo que permitirá aumentar la precisión de las estimaciones de heredabilidad. Asimismo, el contar con un mayor número de datos permitirá estimar correlaciones genéticas entre las diferentes características presentadas en este artículo, así como con las características medidas in vivo de forma rutinaria en las EGP (e.g. pesos corporales, área del ojo de bife, espesor de grasa subcutánea). De esta forma, éstas últimas (características con DEP) podrían ser utilizadas como criterios de selección para mejorar características de calidad de canal y de la carne. Es así que estos trabajos son la base para el desarrollo de objetivos e índices de selección que puedan incluir características de importancia económica post faena, basándose en parámetros de la población Texel del Uruguay.

Cuadro 1. Estadísticas de las distribuciones posteriores de las estimaciones de heredabilidad $\left(h^{2}\right)$ para las características de calidad de canal y de la carne de la raza Texel.

\begin{tabular}{|l|l|c|c|c|c|}
\hline Característica & Media & Mediana & PSD & 95\%HPD & 95\%HPD \\
\hline PCC (kg) & 0,510 & 0,497 & 0,205 & 0,150 & 0,931 \\
French Rack (kg) & 0,834 & 0,866 & 0,134 & 0,568 & 1,000 \\
Paleta (kg) & 0,392 & 0,364 & 0,214 & 0,008 & 0,800 \\
Pierna (kg) & 0,334 & 0,307 & 0,201 & 0,000 & 0,710 \\
Largo canal (cm) & 0,559 & 0,558 & 0,224 & 0,189 & 1,000 \\
Largo pierna (cm) & 0,419 & 0,392 & 0,198 & 0,078 & 0,816 \\
Perímetro pierna (cm) & 0,298 & 0,263 & 0,202 & 0,000 & 0,694 \\
GR (cm) & 0,293 & 0,268 & 0,173 & 0,007 & 0,624 \\
Terneza (kgF) & 0,257 & 0,230 & 0,161 & 0,005 & 0,570 \\
Color a* & 0,304 & 0,265 & 0,198 & 0,011 & 0,698 \\
Color b* & 0,438 & 0,412 & 0,233 & 0,046 & 0,882 \\
Color L* & 0,320 & 0,295 & 0,161 & 0,054 & 0,646 \\
Grasa intramuscular (\%) & 0,274 & 0,240 & 0,170 & 0,007 & 0,606 \\
MUFA (\%) & 0,249 & 0,198 & 0,197 & 0,001 & 0,656 \\
PUFA (\%) & 0,399 & 0,369 & 0,219 & 0,025 & 0,825 \\
SFA (\%) & 0,345 & 0,299 & 0,233 & 0,003 & 0,807 \\
\hline
\end{tabular}

Nota: PSD: Desvío estándar posterior; 95\%HPD: intervalo de credibilidad más corto con un 95\% de probabilidad de contener el verdadero valor, límite inferior $(L)$ y superior (U). Ácidos grasos saturados (SFA), monoinsaturados (MUFA), y poliinsaturados (PUFA). 


\title{
III. DIFERENCIAS EN PESOS AL NACIMIENTO Y DESTETE ENTRE LAS RAZAS CORRIEDALE Y TEXEL
}

\author{
Ciappesoni, G. ${ }^{1}$; Vázquez, A. ${ }^{1}$; Banchero, G. $^{1}$
}

Los cruzamientos son una herramienta de efecto rápido que utiliza la heterosis, las diferencias raciales (individual y maternal) y la complementariedad entre razas. Actualmente muchos criadores de razas doble propósito y laneras han adoptado el cruzamiento terminal con razas carniceras, especialmente sobre las ovejas de mayor diámetro de fibra o más viejas.

Los primeros estudios para evaluar la velocidad de engorde y la calidad carnicera que podía ofrecer la raza Texel, se realizaron en la Facultad de Agronomía y de Veterinaria de la Universidad de la República. Para ello se cruzaron, en pequeña escala, carneros Texel con prácticamente todas las razas existentes en el Uruguay en ese momento (Asociación Rural del Uruguay, 1977). Bianchi y col. (1999) señalan que la cruza de carneros Texel con ovejas Corriedale, corroboran la reputación de esta raza a nivel internacional en lo que se refiere a mejoras en el rendimiento de la canal respecto a la raza pura. Se observaron bajos niveles de grasa, en especial poca grasa subcutánea; mayor contenido muscular, especialmente en corderos con alto peso de canal y en cortes de mayor valor. También describen que el peso al nacer de los corderos cruza Texel x Merino es entre un 5 y un 25\% superior con respecto al Merino puro.

Desde el 2004, se incorporó al plan estratégico de INIA la evaluación de nuevas opciones genéticas (biotipo maternal) que mejoren la competitividad del rubro ovino, en especial para sistemas intensivos (Montossi et al., 2013). En el 2010, basándose en estudios previos (Ganzábal y col., 2007), se decide incorporar la raza Texel en este biotipo maternal con el fin de mejorar la sobrevida desde el nacimiento al destete de los corderos y aportarle al nuevo biotipo mejores características carniceras. Un com- ponente principal de esta nueva evaluación reproductiva fue la implementación de un cruzamiento dialélico entre la raza Texel y Corriedale, realizado en INIA La Estanzuela, con el fin de generar corderas para su futura evaluación con otros biotipos (cruzas y puros).

El objetivo del presente estudio fue analizar los resultados preliminares de los cruzamientos entre Texel y Corriedale para peso al nacimiento y destete, en cuanto a diferencias entre los biotipos obtenidos y los parámetros de cruzamiento.

\section{MATERIALES Y MÉTODOS}

El experimento se realizó en la Unidad de Ovinos de La Estanzuela (34⒈ ${ }^{\prime} 57^{\prime \prime} \mathrm{S}$ $57^{\circ} 40^{\prime} 07^{\prime \prime} \mathrm{O}$ ) del Instituto Nacional de Investigación Agropecuaria (INIA). Se analizaron los resultados de un cruzamiento dialélico entre la raza Corriedale (C) y Texel ( $T$ ), para las características peso al nacimiento (PND, $\mathrm{n}=800$ ) y al destete (PDD, $\mathrm{n}=574$ ). Los corderos nacieron en la primavera de los años 2010, 2011 y 2012. Con el fin de conectar genéticamente las generaciones y los biotipos evaluados, se utilizaron carneros en común como padres en ambos casos. Se utilizaron 19 padres en total, 9 Texel y 10 Corriedale, de estos tres Texel y dos Corriedale, conectaron año. Asimismo, doce de estos conectaron biotipo (i.e. T.T con T.C y C.C con C.T). Todas las corderos se manejaron en forma conjunta desde al nacimiento al destete. La distribución de los datos según biotipo y año de nacimiento se presentan en el Cuadro 1.

Para analizar las diferencias entre los biotipos y los parámetros de cruzamientos se utilizaron los siguientes modelos mixtos: 
(1) $\mathrm{y}_{\mathrm{ijklmno}}=\mathrm{Año}_{\mathrm{i}}+\mathrm{TN}_{\mathrm{j}}+\mathrm{EM}_{\mathrm{k}}+\mathrm{Sexo}_{\mathrm{i}}+$ Biotipo $_{\mathrm{l}}+\beta \mathrm{x}_{\mathrm{ijklmno}}+\mathrm{s}_{\mathrm{n}}+\mathrm{e}_{\mathrm{ijk} \mathrm{kmn}}$

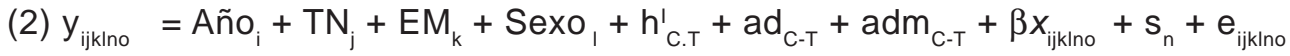

Donde:

$\mathrm{y}_{\mathrm{ijk} \text { lmno }}$ es la característica evaluada, los efectos sistemáticos son: Año año de nacimiento i de los corderos (2010-2012), TN tipo de nacimiento j (2 niveles: único y múltiple), $\mathrm{EM}_{\mathrm{k}}$ edad $k$ de la madre (3 niveles: 2,3 y $\geq 4$ años), Sexo, es el sexo I del cordero (macho o hembra), Biotipo $\mathrm{m}$ es el biotipo $\mathrm{m}$ del cordero (C.C, T.C, C.T, T.T), $x_{\mathrm{ijklmno}}$ es la edad al destete del cordero en días (solo para PDD) siendo $\beta$ la covariable; $h_{C . T}^{1}$ es la heterosis individual entre las razas $\mathrm{T}$ y $\mathrm{C}$; $\mathrm{ad}_{\mathrm{C}-\mathrm{T}}$ diferencia entre el efecto aditivo directo de la raza $\mathrm{C}$ y la $\mathrm{T}$ $(\mathrm{C}-\mathrm{T}), \mathrm{adm}_{\mathrm{C}-\mathrm{T}}$ diferencia entre el efecto aditivo materno de la raza $\mathrm{C}$ y la $\mathrm{T}(\mathrm{C}-\mathrm{T})$., $\mathrm{S}_{\mathrm{n}}$ es el efecto aleatorio del padre $n, y e_{i j k l m n o}$ es el residuo aleatorio del modelo. Ambos análisis se realizaron mediante el procedimiento Mixed del paquete estadístico SAS, con el método ML (Statistical Analysis System, Version 9.2, 2008).

\section{RESULTADOS Y DISCUSIÓN}

Los resultados presentados son preliminares dado que, como se observa en el Cuadro 1, aún no se han completado tres años del cruzamiento dialélico completo, este se completará con la generación 2013.

En el Cuadro 2, se presentan los niveles de significancia para los diferentes efectos

Cuadro 1. Número de corderos con peso al nacimiento y destete según biotipo y año.

\begin{tabular}{|l|c|c|c|c|c|c|c|c|}
\hline & \multicolumn{3}{|c|}{ Peso al nacimiento } & \multicolumn{4}{c|}{ Peso al destete } \\
\hline $\mathbf{n}$ & $\mathbf{2 0 1 0}$ & $\mathbf{2 0 1 1}$ & $\mathbf{2 0 1 2}$ & Total & $\mathbf{2 0 1 0}$ & $\mathbf{2 0 1 1}$ & $\mathbf{2 0 1 2}$ & Total \\
\hline C.C & 96 & 112 & 77 & 285 & 63 & 85 & 42 & 190 \\
C.T & 0 & 49 & 57 & 106 & 0 & 41 & 46 & 87 \\
T.C & 125 & 103 & 74 & 302 & 98 & 83 & 44 & 225 \\
T.T & 0 & 54 & 53 & 107 & 0 & 34 & 38 & 72 \\
\hline Total & 221 & 318 & 261 & 800 & 161 & 243 & 170 & 574 \\
\hline
\end{tabular}

Cuadro 2. Nivel de significancia de los efectos fijos y covariables utilizados en los modelos 1 y 2, para evaluar peso al nacimiento (PND) y al destete (PDD).

\begin{tabular}{|l|c|c|c|c|}
\hline \multirow{2}{*}{} & \multicolumn{2}{|c|}{ Modelo 1 } & \multicolumn{2}{c|}{ Modelo 2 } \\
\cline { 2 - 5 } & PND & PDD & PND & PDD \\
\hline Edad & - & $<0,0001$ & - & $<0,0001$ \\
Año & $<0,0001$ & $<0,0001$ & $<0,0001$ & $<0,0001$ \\
TN & $<0,0001$ & $<0,0001$ & $<0,0001$ & $<0,0001$ \\
Sexo & 0,0052 & 0,0032 & 0,0052 & 0,0032 \\
EM & $<0,0001$ & 0,0044 & $<0,0001$ & 0,0044 \\
Biotipo & 0,077 & $<0,0001$ & - & - \\
$\mathrm{h}_{\text {C.T }}^{\prime}$ & - & - & 0,6917 & 0,2777 \\
$\operatorname{adm}_{\text {C-T }}$ & - & - & 0,6059 & 0,1307 \\
$\operatorname{ad}_{\text {C-T }}$ & - & - & 0,0430 & 0,0003 \\
\hline
\end{tabular}

Nota: $h_{C T}^{1}$ heterosis individual entre las razas $T$ y $C$; $\operatorname{ad}_{C-T}$ diferencia entre el efecto aditivo directo de la raza $\mathrm{C}$ y la $\mathrm{T}(\mathrm{C}-\mathrm{T})$, adm $\mathrm{C}_{\mathrm{C}-\mathrm{T}}$ diferencia entre el efecto aditivo materno de la raza $C$ y la $T(C-T)$. 
sobre el peso al nacimiento y al destete según el modelo utilizado. Los efectos de año de nacimiento, tipo de nacimiento, sexo y edad de la madre fueron significativos, para ambas características y ambos modelos (Cuadro 2). El efecto de la edad al destete fue altamente significativo para ambos modelos $(P<0,0001)$. Es así, que se destaca la importancia de registrar estos efectos al momento de evaluar diferentes opciones genéticas, con el fin de no penalizar o favorecer a algún biotipo. El efecto del biotipo fue altamente significativo para el PDD, sin embargo en el caso del PND el grado de significancia fue de $P=0,077$. De los parámetros de cruzamientos, sólo la diferencia entre el efecto aditivo directo entre la raza Corriedale y Texel fue significativo (Cuadro 2).

Las medias de mínimos cuadrados para PND y PDD según biotipo y las soluciones para los parámetros de cruzamientos se presentan en el Cuadro 3. Pese a que los corderos T.T pesaron $0,327 \mathrm{~kg}$ más en promedio al nacimiento que los C.C., esta diferencia no fue significativa $(P>0.05)$. Es de esperar que con el aumento del número de datos disminuyan los errores estándares y se detecten diferencias también para esta característica. Esta diferencia se ve reflejada, en el parámetro $\operatorname{ad}_{\mathrm{C}-\mathrm{T}}$, indicando que existe un efecto aditivo directo de la raza Texel produciendo corderos $0,405 \mathrm{~kg}$ más pesados al nacimiento que la raza Corriedale $(P=0,0430)$.

Al destete los corderos T.T son los más pesados, los C.C los más livianos y los F1 presentan valores intermedios. Se observa un efecto aditivo directo $\left(\mathrm{ad}_{\mathrm{C}-\mathrm{T}}\right)$ de la raza Texel de 2,83 kg sobre la Corriedale. Por otra parte, si bien no es significativo $(P=0,1307)$ el efecto aditivo maternal $\left(\mathrm{adm}_{\mathrm{C}-\mathrm{T}}\right)$ de la raza Texel determinaría destetar corderos $0,90 \mathrm{~kg}$ más pesados. Esta diferencia se observa al comparar ambas $\mathrm{F} 1$, que pese a tener la misma composición genética $(50 \% \mathrm{C}$ y $50 \% \mathrm{~T}$ ), se diferencian por tener madres de distintos biotipos. La heterosis para peso al destete, solo representó un $2 \%$ y no fue significativa $(P=0,6917)$.

En otras palabras, la diferencia significativa $(P<0,05)$ en peso al destete ente los corderos puros Corriedale y Texel es de $3,73 \mathrm{~kg}$ (19\%), siendo el resultado de que el cordero es $100 \%$ Texel $(2,83 \mathrm{~kg}, 14 \%$, efecto aditivo directo) y su madre también es $100 \%$ Texel $(0,90 \mathrm{~kg}, 5 \%$, efecto aditivo maternal).

Al analizar las soluciones del efecto padre (aleatorio), se observan una amplia variación tanto dentro de los carneros Corriedale como los Texel. La diferencia máxima entre el efecto de dos carneros Corriedale es de $0,23 \mathrm{~kg}$ para PND y de

Cuadro 3. Medias de mínimos cuadrados para peso al nacimiento (PND) y al destete (PDD) según biotipo y estimadores de los parámetros de cruzamiento.

\begin{tabular}{|l|l|l|l|l|}
\hline \multirow{2}{*}{} & \multicolumn{2}{|c|}{ Peso al nacimiento } & \multicolumn{2}{c|}{ Peso al destete } \\
\cline { 2 - 5 } & LSM & e.e. & LSM & e.e. \\
\hline C.C & $4,36^{\mathrm{a}}$ & 0,11 & $17,88^{\mathrm{c}}$ & 0,45 \\
C.T & $4,52^{\mathrm{a}}$ & 0,11 & $20,55^{\mathrm{a}, \mathrm{b}}$ & 0,43 \\
T.C & $4,60^{\mathrm{a}}$ & 0,11 & $19,65^{\mathrm{b}}$ & 0,45 \\
T.T & $4,69^{\mathrm{a}}$ & 0,11 & $21,61^{\mathrm{a}}$ & 0,45 \\
$\mathrm{~h}_{\text {C.T }}^{\prime}$ & 0,03 & 0,08 & 0,36 & 0,33 \\
adm $_{\text {C-T }}$ & 0,08 & 0,15 & $-0,90$ & 0,59 \\
ad $_{\text {C-T }}$ & $-\mathbf{0 , 4 0}$ & 0,20 & $\mathbf{- 2 , 8 3}^{\star *}$ & 0,78 \\
\hline
\end{tabular}

Nota: $\mathrm{h}_{\mathrm{C} . \mathrm{T}}^{1}$ heterosis individual entre las razas $\mathrm{T}$ y $\mathrm{C}$; $\operatorname{ad}_{\mathrm{C}-\mathrm{T}}$ diferencia entre el efecto aditivo directo de la raza $\mathrm{C}$ y la $\mathrm{T}(\mathrm{C}-\mathrm{T})$, adm $\mathrm{C}_{\mathrm{C}-\mathrm{T}}$ diferencia entre el efecto aditivo materno de la raza $C$ y la $T(C-T)$. Diferentes superíndices en la misma columna indican diferencias estadísticamente significativas entre los biotipos $(P<0,05)$. LSM: medias de mínimos cuadrados, e.e. error estándar. ${ }^{*} \mathrm{P}<0,05,{ }^{*} \mathrm{P}<0,001$. 
$0,96 \mathrm{~kg}$ para PDD. Estos valores son para la raza Texel de 0,31 y 0,99 kg respectivamente. Sin embargo, estos datos deben de ser tenidos en cuenta dentro de biotipo. Para comparar los carneros de diferentes razas se debe considerar la diferencia racial aditiva entre ambas razas. Para el caso del peso al destete, tomando en cuenta la diferencia racial ( $\mathrm{ad}_{\mathrm{C}-\mathrm{T}}$ Cuadro 3), el carnero Texel que más aumenta el peso al destete presenta un estimador de $+1,91 \mathrm{~kg}$, siendo el valor mínimo para un carnero de esta raza de $+0,92 \mathrm{~kg}$. Para la raza Corriedale, el valor máximo fue de $-0,90 \mathrm{~kg}$ y el mínimo de $-1,86 \mathrm{~kg}$ al destete.

La correcta estimación de los parámetros de los cruzamientos es fundamental para el diseño adecuado de sistemas de cruzamientos, que le ofrezcan a los productores diferentes opciones para aprovechar al máximo la diferencia y heterosis entre las razas.

\section{CONCLUSIONES GENERALES}

Existen en Uruguay diferentes herramientas para la mejora genética de la producción y calidad de la carne ovina. Algunas estudiadas y disponibles hace varios años (i.e. cruzamientos), otras más recientes (i.e. evaluaciones genéticas) y finalmente, otras en estudio dentro de plataformas para estudios genómicos (i.e. selección asistida por la genómica). Estas diferentes herramientas son complementarias y correctamente combinadas permitirían aumentar el beneficio económico del productor. Si nos planteamos la opción más simple, un cruzamiento terminal (carnero de raza carnicera) sobre una raza doble propósito, la progenie cruza (F1) podrá verse beneficiada en primer lugar de la heterosis individual (vigor híbrido) de esta cruza y de la diferencia racial a favor de la raza carnicera para características relacionadas al crecimiento. En nuestro estudio, la F1 pesaba 2,2 kg (12\%) más al destete que la raza doble propósito. Si adicionalmente, se eligen correctamente los carneros a utilizar dentro de la evaluación genética de la raza terminal, siguiendo nuestro ejemplo, se podría diferenciar en base a las DEP (peso al destete, recría), carneros que se encuentren en el 1\% superior de la población. En el caso del peso al destete, estos carneros ten- drían hijos 1,7 kg (10\%) más pesados al destete que carneros «promedios» de la raza. Asimismo, si la genética de la raza terminal se obtiene de cabañas que tengan un objetivo de selección definido, es de esperar que estas mantengan un progreso continuo para las características de interés económico en la producción de carne. En nuestro ejemplo este progreso oscilaba entre el 0,7 y el 2,7 $\%$ anual.

Si bien existen diversas áreas de oportunidad, en la utilización y la mejora de la genética para la producción de carne de calidad, son números los productores ovinos que conocen y utilizan las herramientas disponibles, observándose un exponencial desarrollo en los últimos años reflejando el dinamismo del sector.

\section{BIBLIOGRAFÍA}

ASOCIACIÓN RURAL DEL URUGUAY. 1977. Cinco años del Texel en el Uruguay. Mayo. Entrega I: Pág. 1-3.

AZZARINI, M. 2000. El cordero pesado tipo SUL. Un ejemplo de desarrollo integrado en la producción de carne ovina del Uruguay. Seminario de Producción de Carne Ovina. Viedma. Trabajos presentados. INTA. Serie técnica 18: pp 78-94.

BIANCHI, G.; GARIBOTTO, G.; OLIVEIRA, G.; BENTANCUR, O.; CASARETTO, A.; CASTELLS, D.; PLATERO, M.; NIN, J.; MORROS, J. 1999. Cruzamientos terminales sobre ovejas Corriedale en el Uruguay; 1 . Velocidad de crecimiento, grado de terminación y dimensión del M.Longissimuis dorsi en corderos livianos y pesados. ITEA. 95 A (3): 234 -247.

CIAPPESONI, G.; GIMENO, D. 2012. Evaluación genética poblacional de animales de la Raza Texel en el Uruguay. INIA. Serie de Catálogos $\mathrm{N}^{\circ}$ 25. pp 28.

CIAPPESONI, G.; NAVAJAS, E.A; SAN JULIÁN, R.; BRITO, G.; GIMENO, D.; GOLDBERG, V. 2012. Genetic variability of carcass and meat quality of the Texel breed under grazing conditions. Proceedings of 4 th International Conference on 
Quantitative Genetics. Edinburgh 17-22 June 2012. P-323. pp. 217. Disponible en http://www.icqg2012.org.uk/

CLOETE, S.W.P; CLOETE, J.J.E, HOFFMAN, L.C. 2008. Heritability estimates for slaughter traits in South African terminal crossbred lambs.'Proceedings of the 54th international congress of meat science and technology', Cape Town, South Africa. Session 4, p. 3.

DICOSE. 2012. Declaración jurada 2012, División Contralor de Semovientes, Ministerio de Ganadería Agricultura y Pesca. http://www.mgap.gub.uy/DGSG/ DICOSE/dicose.htm

GANZÁBAL, A.; MONTOSSI, F.; CIAPPESONI, G.; BANCHERO, G.; RAVAGNOLO, O.; SAN JULIÁN, R.; LUZARDO, S. 2007. Cruzamientos para la producción de carne ovina de calidad. Resultados: Comportamiento reproductivo y habilidad materna de ovejas, crecimiento y calidad de la canal de corderos. INIA. Serie técnica 170. pp. 28-36.

MISZTAL, I.; TSURUTA, S.; STRABEL, T.; AUVRAY, B.; DRUET, T.; LEE, DH. 2002. BLUPF90 and related programs (BGF90). Proc. 7th WCGALP, Montpellier, France. Communication No 28-07. 190. 2012.
MONTOSSI, F.; DE BARBIERI, I.; CIAPPESONI, G.; GANZÁBAL, A.; BANCHERO, G.; LUZARDO, S.; SAN JULIÁN, R. 2013. Intensification, diversification, and specialization to improve the competitiveness of sheep production systems under pastoral conditions: Uruguay's case. Animal Frontiers July 2013, 3:28-35; doi:10.2527/af.20130021 Print ISSN: 2160-6056.

PEREIRA, S. 2012. Factores que afectan el crecimiento y calidad de la canal en corderos Texel del Uruguay. Tesis de grado. Técnico Agrícola Ganadero Universidad del Trabajo del Uruguay (UTU).

SAN JULIÁN, R.; BRITO, G.; LAGOMARSINO, X.; DE SOUZA, G. 2012. Descripción de variables de calidad de canal y carne de corderos Texel. Primer Seminario Internacional de carne ovina. Cuarenta años de Texel en Uruguay. Rural del PradoMontevideo,Uruguay. Disponible e n h t t p : / / w w w. sul.org.u y / seminario_carne_ovina_2012_inscripcion.asp

WALDRON, D.F.; CLARKE, J.N.; RAE, A.L.; KIRTON A.H.; BENNETT, G.L. 1992. Genetic and phenotypic parameter estimates for selection to improve lamb carcass traits, New Zealand Journal of Agricultural Research, 35:3, 287-298. 


\title{
IMPACTO PRODUCTIVO Y ECONÓMICO DEL USO DE BIOTIPOS MATERNALES EN LA PRODUCCIÓN DE CORDEROS
}

A. Ganzábal ${ }^{1}$

\section{RESUMEN}

\begin{abstract}
En el presente trabajo fueron modelados y comparados cinco Sistemas pastoriles de producción de corderos, desarrollados en las mismas condiciones de base forrajera, escala y manejo y se diferencian en raza o biotipo, peso vivo adulto y edad a la primera encarnerada. El Sistema 1 utiliza ovejas Corriedale de $45 \mathrm{~kg}$, el Sistema 2 tiene ovejas Corriedale de $60 \mathrm{~kg}$, el Sistema 3 maneja ovejas Corriedale de $45 \mathrm{~kg}$ y utiliza cruzamientos terminales con razas carniceras, el Sistema 4 corresponde a biotipos maternales y con el uso de cruzamientos terminales y finalmente el Sistema 5 emplea biotipos maternales y la primera encarnerada se realiza a las corderas con 7 meses. Los ingresos familiares obtenidos en los cinco Sistemas (1 al 5) fueron 206, 204, 300, 479 y 534 U\$S, respectivamente.
\end{abstract}

Palabras clave: ovinos, biotipos prolíficos, sistemas intensivos

\section{INTRODUCCIÓN}

Desde hace algunos años la venta de cordero constituye el principal ingreso de nuestros sistemas de producción intensivos y semi-intensivos. En este marco comercial con perspectivas ciertas de continuidad, el comportamiento reproductivo y la habilidad materna constituyen los parámetros productivos de mayor incidencia sobre los resultados económicos de este tipo de explotaciones.

Por otra parte, pocas veces a lo largo de estos casi dos siglos de desarrollo, los valores internacionales de la carne ovina y de la lana han sido simultáneamente tan competitivos como en los últimos tiempos, particularmente las lanas finas y superfinas. Paradójicamente, las excelentes condiciones de los mercados internacionales para sus dos principales productos, se contraponen a existencias ovinas situadas en sus mínimos históricos, particularmente si se consideramos su génesis a partir de consolidada la «Revolución Lanar», iniciada a mediados del siglo XIX.
Como contraparte, el desarrollo tecnológico de la ovinocultura uruguaya no se detuvo ni aún en momentos en que el rubro debió enfrentar las mayores dificultades de su historia. Durante un extenso período que abarcó la década de los noventa y gran parte de este nuevo siglo, bajos precios de las lanas, mercados inciertos para la carne, abigeato, grave incidencia de depredadores, entre otros, constituyeron obstáculos que no solamente pusieron en duda su histórico desarrollo, sino la continuidad de nuestra cultura ovejera, cimiento fundamental de esta actividad.

Afortunadamente, esta continuidad nos permite disponer hoy de una gran oferta en herramientas tecnológicas, adaptadas para su adopción en sistemas modernos, capaces de darle competitividad al rubro aún en momentos en que debe disputar su lugar con rubros altamente competitivos de la agropecuaria nacional, que gozan de oportunidades comerciales y tecnológicas muy favorables.

Los precios alcanzados en la actualidad por la carne ovina no dejan dudas sobre las

${ }^{1}$ Ing. Agr., Investigador Principal, Programa de Carne y Lana, INIA. 
conveniencias de priorizar los esquemas que permiten maximizar los ingresos por concepto de venta de corderos, al menos en aquellas situaciones productivas en las cuales las mejoras forrajeras son posibles en algún grado.

Todo esto de la mano de un proceso de intensificación creciente, de una mejora en los comportamientos reproductivos, aumentos en las velocidades de crecimiento de los corderos y seguramente en un futuro no muy lejano, en las cualidades de las canales y la carne producida. Conceptos todos ellos que contrastan fuertemente con las tradicionales e históricas formas de cría y que generan la necesidad incluso y una vez más de algún grado de modificaciones genéticas.

La oveja a partir de su domesticación, desde su propio origen y de la mano del hombre, ha ido ajustándose a las más variadas condiciones ambientales, productivas, culturales y comerciales, desarrollando en cada una de ellas estrategias de supervivencia y adaptación, a la vez de la multiplicidad en la oferta de sus productos.

Estas diversidades que surgen de procesos deliberados o accidentales, han llevado a que hoy existan razas, biotipos o líneas con potencialidades genéticas particulares y muy variadas aptitudes productivas, desarrolladas para dar satisfacción a las necesidades humanas más diversas.

A partir de este proceso evolutivo tan particular, la especie es capaz de reunir entre sus diferentes razas y biotipos, características biológicas que inteligentemente aprovechadas nos ofrecen la oportunidad de desarrollar sistemas de producción eficientes y competitivos, donde se destacan:

- Precocidad sexual.

- Posibilidad de partos múltiples.

- Ciclos productivos cortos.

Estos atributos, a su vez, posibilitan satisfacer los dos componentes básicos de la ecuación productiva en un eficiente sistema pastoril productor de corderos: cantidad de corderos vendidos y velocidad de crecimiento (peso de venta o edad de venta) por unidad reproductiva con un adecuado tamaño adulto.
Hasta hace algunos años atrás la ovinocultura uruguaya, no presentó la necesidad de explotar al máximo estos atributos de la especie, que toman especial relevancia en los actuales escenarios comerciales en los cuales la relación precio del cordero/ precio de la carne se vuelve más favorable hacia el primero y la presión del aumento del precio de la tierra y/la renta de la misma, al tiempo que otros rubros de la agropecuaria nacional van transitando caminos de competitividad que están desplazando a las propuestas tradicionales.

El presente trabajo tiene como principal objetivo cuantificar la incidencia productiva y económica de la introducción de los biotipos prolíficos en sistemas intensivos de producción, y por tanto, estimar en forma aproximada el impacto esperable a partir de la adopción de estas estrategias tecnológicas.

\section{MATERIALES Y MÉTODOS}

Para la realización del siguiente trabajo fue utilizado el modelo matemático propuesto por Ganzábal, A. (sin publicar). El modelo fue ajustado fundamentalmente en base a los resultados de los modelos físicos desarrollados en la Unidad de Ovinos de INIA La Estanzuela entre los años 1982 y 1988 (Castro, y Ganzábal, 1988, Castro y col., 1988, Ganzábal, 1988 y Ganzábal y col., 2001).

El sistema elegido para las comparaciones entre las diferentes estrategias tecnológicas, es el de ciclo completo (involucra ciclos reproductivos y engorde o «invernada» de corderos), Fue desarrollado sobre la base de 100 ha, asumiendo un 90\% del área mejorada.

Las funciones de respuesta, así como las diferencias estimadas en parámetros productivos y reproductivos vinculados a los biotipos maternales y terminales empleados para suministrar información al modelo, fueron obtenidos en todos los casos a partir de trabajos de investigación nacionales, desarrollados en condiciones pastoriles y tomando como base la información del comportamiento obtenidos en ovejas de raza Corriedale en 
sistemas físicos y durante varios años de evaluación, (Castro y Ganzábal, 1988, Castro et al., 1988, Ganzábal,1988 y Ganzábal et al., 2001). Esta raza, por su importancia a nivel nacional es tomada como referencia (testigo) en la mayoría de los trabajos de evaluación reportados en el siguiente trabajo.

En el presente estudio fueron modelados y comparados en sus resultados productivos y económicos, cinco sistemas desarrollados sobre una idéntica base forrajera, escala y manejo, sobre los cuales se ha hecho variar el peso vivo de las ovejas, el biotipo maternal, la utilización de cruzamientos terminales y en un caso la edad al primer servicio, a los efectos de cuantificar el efecto estimado de estas variables sobre los resultados productivos y económicos de cada sistema y comparar su productividad e ingreso.

Los biotipos, peso vivo al inicio de la encarnerada de cada uno de ellos, el sistema de apareamiento y la edad al primer servicio en los cinco casos evaluados se describen en el Cuadro 1.

Dado que el peso vivo de la oveja en el momento de la encarnerada (efecto dinámico) tiene una incidencia directa sobre la tasa ovulatoria y por tanto sobre el porcentaje de parición (cordero nacido/oveja encarnerada), el modelo mediante una función predice el porcentaje de parición de acuerdo al peso vivo de ovejas Corriedale a la encarnerada (Ganzábal, 2005):

$$
\mathrm{Y}=34,91+1,94 \times \mathrm{PV}
$$

Donde:

Y = Porcentaje de parición (cordero nacido/ oveja encarnerada)

PV = Peso Vivo de la oveja adulta al inicio de la encarnerada $(\mathrm{kg})$.

Las funciones de respuesta entre asignación de forraje (\% PV) y consumo de MS (g/día) empleadas en el modelo para la determinación de la carga ovina de cada uno de los Sistemas, fueron extraídas de Ganzábal (1997) y las funciones de respuesta entre asignación de forraje (en \% PV) y la tasa de crecimiento de los corderos (g/día) (Ganzábal, sin publicar). Las asignaciones de forraje empleadas como variables del modelo, para la alimentación de las ovejas y de los corderos, en sus diferentes etapas fisiológicas, fueron definidas en función de establecer un equilibrio apropiado entre el aprovechamiento del forraje producido y la manifestación de un comportamiento individual que sin llegar a la manifestación del potencial genético del biotipo, permite reducir los costos relativos de mantenimiento fisiológico de las ovejas de cría.

La asignación de forraje promedio a los corderos desde el momento del destete hasta el día de la faena fue considerado en promedio de $10 \%$ de su peso vivo lo que se corresponde con una ganancia de peso comprendida entre 120 y 150 g/día con excepción del período conocido como depresión otoñal (Banchero y col., 2006), momento en el cual la evolución promedio de peso a la misma asignación de forraje es considerada de 40 g/día.

Cuadro 1. Presentación de los 5 sistemas productivos modelados.

\begin{tabular}{|l|c|c|c|c|c|}
\hline \multicolumn{1}{|c|}{ Sistema } & $\mathbf{1}$ & $\mathbf{2}$ & $\mathbf{3}$ & $\mathbf{4}$ & $\mathbf{5}$ \\
\hline Raza o biotipo de la madre & Corriedale & Corriedale & Corriedale & $\begin{array}{c}\text { Biotipo } \\
\text { maternal }\end{array}$ & $\begin{array}{c}\text { Biotipo } \\
\text { maternal }\end{array}$ \\
\hline $\begin{array}{l}\text { Peso vivo de la madre } \\
\text { adulta a la encarnerada }(\mathrm{kg}) \\
\text { Raza o biotipo del carnero }\end{array}$ & $\begin{array}{c}45 \\
\text { Corriedale }\end{array}$ & $\begin{array}{c}60 \\
\text { Corriedale }\end{array}$ & $\begin{array}{c}45 \\
\text { Raza } \\
\text { terminal } \\
\text { carnicera }\end{array}$ & $\begin{array}{c}55 \\
\text { Raza } \\
\text { terminal } \\
\text { carnicera }\end{array}$ & $\begin{array}{c}55 \\
\text { Raza } \\
\text { terminal } \\
\text { carnicera }\end{array}$ \\
\hline $\begin{array}{l}\text { Edad al primer servicio } \\
\text { (meses) }\end{array}$ & 18 & 18 & 18 & 18 & 7 \\
\hline
\end{tabular}


El peso de venta de los corderos se consideró de $35 \mathrm{~kg}$, constante entre los cinco Sistemas evaluados, lo que determina que los diferentes biotipos con diferentes velocidades de crecimiento de sus corderos, presenten fechas de faena diferentes y por tanto diferentes tiempos de permanencia en el Sistema, lo que genera un impacto importante sobre la eficiencia global en un Sistema pastoril. Este peso puede constituir alternativamente producto cordero precoz o cordero pesado dependiendo de la tasa de evolución de peso y por tanto de la edad de faena.

En el Cuadro 2, se puede observar los valores de incremento en los parámetros reproductivos y productivos considerados, cuando se comparan los biotipos maternales con razas laneras puras y los valores incrementales en parámetros productivos (velocidad de crecimiento), cuando se comparan con razas terminales.

Para la estimación de las diferencias consideradas entre el biotipo maternal y la raza Corriedale en parámetros reproductivos y en peso vivo de las ovejas en el momento del servicio (Cuadro 2), se consideraron las registradas entre Corriedale (C) y Cruza Frisona Milchschaf (FM) x Finnish Landrace (FL), (FMxFL). (Ganzábal y col., 2013).
Para la estimación de las diferencias en tasa de crecimiento de corderos F1 producto de cruzamientos terminales, con respecto a corderos puros de razas laneras (Cuadro 2), fueron utilizados los resultados de los trabajos de cruzamientos con Poll Dorset (PD), realizados por Ganzábal (sin publicar). Las diferencias utilizadas en velocidad de crecimiento de los corderos por efecto de la mayor producción de leche de los biotipos maternales (FM x Ideal (I) con respecto a razas laneras fueron extraídas de Ganzábal y col. (2007).

Para la asignación de las diferencias en producción individual y finura de lana (para la estimación del precio) se tomaron en cuenta las diferencias en los registros obtenidos entre ovejas de raza Corriedale y Cruza FMxFL, en los trabajos de evaluación de biotipos prolíficos (Ganzábal y col., 2011).

Los precios de los productos y los costos de los principales insumos considerados en el modelo se resumen en los Cuadros 3 y 4 .

Las estimaciones de costos de las pasturas y fertilizantes fueron obtenidas de información suministrada por «Instituto Plan Agropecuario-Programa de Monitoreo de Empresas Ganaderas» (Molina C., comunicación personal).

Cuadro 2. Parámetros utilizados en la modelación de los diferentes Sistemas.

\begin{tabular}{|c|c|c|c|}
\hline Parámetro & Unidad & Incremento & Fuente \\
\hline $\begin{array}{l}\text { Cordero nacido/oveja } \\
\text { encarnerada }\end{array}$ & Puntos Porcentuales & +90 & Ganzábal y col. (2013) \\
\hline $\begin{array}{l}\text { Cordero nacido/cordera } \\
\text { encarnerada }\end{array}$ & Puntos Porcentuales & +100 & Ganzábal (no publicado) \\
\hline Peso al nacer & $\mathrm{kg}$ & $+0,35$ & Ganzábal, (no publicado) \\
\hline $\begin{array}{l}\text { Evolución de peso de } \\
\text { los corderos por producción } \\
\text { de leche de la madre }\end{array}$ & kg/día & $+0,035$ & Ganzábal y col. (2007) \\
\hline $\begin{array}{l}\text { Evolución de peso nacimiento } \\
\text {-destete por efecto directo } \\
\text { de cruzamiento }\end{array}$ & kg/día & $+0,035$ & Ganzábal (no publicado) \\
\hline $\begin{array}{l}\text { Evolución de peso destete- } \\
\text { faena por efecto directo de } \\
\text { cruzamiento }\end{array}$ & kg/día & $+0,024$ & Ganzábal (no publicado) \\
\hline $\begin{array}{l}\text { Peso vivo de la oveja en el } \\
\text { servicio }\end{array}$ & $\mathrm{kg}$ & +6 & Ganzábal y col. (2013) \\
\hline Producción de lana vellón & kg oveja/año & $-1,3$ & Ganzábal y col. (2011) \\
\hline Diámetro de la lana & Micras & $+0,9$ & Ganzábal y col. (2011) \\
\hline
\end{tabular}


Cuadro 3. Principales costos de producción asumidos.

\begin{tabular}{|l|c|}
\hline Concepto & Costo U\$S \\
\hline Pradera/ha & 336 \\
Verdeo/ha & 328 \\
Fertilizante/kg & 0,572 \\
\hline
\end{tabular}

Cuadro 4. Principales precios de venta asumidos.

\begin{tabular}{|l|c|c|}
\hline Producto & Características & Precio U\$S kg \\
\hline Lana Corriedale & $29,8 \mu$ & 3,2 \\
Lana Biotipo & $30,7 \mu$ & 3,1 \\
Maternal & & \\
Carne Cordero & Segunda balanza & 3,8 \\
Carne Adulto & Segunda balanza & 3,4 \\
\hline
\end{tabular}

Los resultados económicos del presente trabajo se expresan en términos de ingreso familiar (IF) y en US\$/ha en la medida de que la propuesta está orientada fundamentalmente a productores familiares de pequeña y mediana escala y a los efectos de que el costo de la tierra y la remuneración a los recursos humanos (variables que generalmente presentan diferencias entre diferentes situaciones y regiones del país) no introduzcan dificultades adicionales a los efectos de su interpretación.

\section{RESULTADOS Y DISCUSIÓN}

En el Cuadro 5 se presentan los resultados productivos y económicos de los cinco sistemas propuestos en el presente estudio comparativo.

Como ya fue expresado el peso vivo (PV) de una oveja en el momento de la ovulación presenta una relación directa con la tasa ovulatoria y por tanto con la cantidad de corderos nacidos algunos meses después (Ganzábal, 2005). Sin embargo, en sistemas pastoriles este efecto directo y positivo presenta como contraparte el hecho de que en la medida que aumenta el peso de la oveja disminuye proporcionalmente la capacidad de carga del sistema considerado. Para el presente estudio el sistema 1, fue tomado como referencia o testigo en la medida que ha sido validado y se corresponde con los resultados obtenidos en modelos físicos de muchos años de funcionamiento (Castro y Ganzábal, 1988).

El sistema 2 ha sido evaluado con una línea diferente de ovejas Corriedale de $60 \mathrm{~kg}$ de PV (a diferencia del sistema 1 en el cual las ovejas consideradas fueron de $45 \mathrm{~kg}$ de $\mathrm{PV})$, esto determina que debió ser considerado un incremento en la tasa ovulatoria, que

Cuadro 5. Resultados productivos y económicos obtenidos en los diferentes sistemas de producción modelados.

\begin{tabular}{|l|c|c|c|c|c|}
\hline \multicolumn{1}{|c|}{ Sistema } & $\mathbf{1}$ & $\mathbf{2}$ & $\mathbf{3}$ & $\mathbf{4}$ & $\mathbf{5}$ \\
\hline Raza o Biotipo de la oveja & Corriedale & Corriedale & Corriedale & $\begin{array}{c}\text { Biotipo } \\
\text { maternal }\end{array}$ & $\begin{array}{c}\text { Biotipo } \\
\text { maternal }\end{array}$ \\
\hline $\begin{array}{l}\text { Peso vivo de la madre a la } \\
\text { encarnerada (kg) }\end{array}$ & 45 & 60 & 45 & 51 & 51 \\
\hline Raza o Biotipo del Carnero & Corriedale & Corriedale & $\begin{array}{c}\text { Raza } \\
\text { terminal } \\
\text { carnicera }\end{array}$ & $\begin{array}{c}\text { Raza } \\
\text { terminal } \\
\text { carnicera }\end{array}$ & $\begin{array}{c}\text { Raza } \\
\text { terminal } \\
\text { carnicera }\end{array}$ \\
\hline Carga Ovina (Ovejas/ha) & 7,9 & 6,1 & 10,0 & 8,4 & 8,4 \\
\hline$\%$ Destete Adultas & 89,3 & 111 & 89,3 & 157,1 & 157,1 \\
\hline $\begin{array}{l}\text { \% Destete en Corderas } \\
\text { Diente de Leche }\end{array}$ & 0 & 0 & 0 & 0 & 78 \\
\hline $\begin{array}{l}\text { Producción de lana (kg/ha) } \\
\text { Producción peso vivo (kg /ha) }\end{array}$ & 176,3 & 178,1 & 222,0 & 345,8 & 377,7 \\
\hline \begin{tabular}{l} 
Ingreso Familiar (US\$/ha) \\
\hline
\end{tabular} & 206 & 204 & 300 & 479 & 534 \\
\hline
\end{tabular}


se ve reflejado en un mayor número relativo de corderos destetados con respecto al sistema 1, (111\% vs $89 \%)$. Sin embargo, este mejor comportamiento reproductivo no se ve reflejado en una mayor producción de carne por unidad de superficie (178,1 vs 176,3), debido a que la capacidad de carga del sistema desciende de 7,9 a 6,1 ovejas por ha y por tanto la cantidad de corderos vendidos (en valor absoluto) permanece relativamente constante y como consecuencia indirecta baja la producción de lana por unidad de superficie.

Por tanto, la disminución en el número de ovejas por ha no es compensada, de acuerdo a los resultados obtenidos, por el incremento registrado en el porcentaje de corderos destetados, por el mayor peso al nacer, ni por el incremento en la producción individual de lana. Como consecuencia los resultados económicos expresados como IF permanecen relativamente constantes entre ambos sistemas (206 vs 204 US\$/ha/año).

El sistema 3 incorpora los cruzamientos terminales con razas carniceras como herramienta tecnológica, tendiente a mejorar la velocidad de crecimiento de los corderos en los períodos comprendidos entre el nacimiento y el destete y entre el destete y la faena. Una mayor velocidad de crecimiento determina un acortamiento de los ciclos productivos permitiendo obtener mayores pesos de faena (cuando se mantiene constante la edad de la misma) o menores tiempos de permanencia de los corderos en el sistema, cuando la faena se realiza a un peso predeterminado y constante.

Un animal en pastoreo presenta requerimientos para mantenerse y para producir y estos requerimientos deben ser extraídos de las pasturas en las cuales se alimenta. La eficiencia de un sistema pastoril, en primera instancia, depende la obtención de un fino equilibrio entre el aprovechamiento de la pastura y la manifestación de sus potencialidades genéticas productivas, siendo que ambas se encuentran inversamente relacionadas (Ganzábal, 1997). Pero además la eficiencia de este tipo de sistemas, está relacionada a la cantidad relativa de alimento que se destina al mantenimiento de los anima- les y la proporción de alimento que se destina al crecimiento y a la producción de lana.

Cuanto mayor sea la proporción de alimento total consumido que se destina al mantenimiento, menor será la eficiencia global del sistema. Un sistema criador mantiene mucho más PV de animales en mantenimiento que un «invernador». A su vez, un animal que no gana peso está destinando la totalidad de su alimento a mantenerse y su crecimiento y capacidad de producir están limitadas. Por tanto, cuanto mayor es la velocidad de crecimiento de un cordero mayor es su eficiencia diaria y menor el tiempo de permanencia en el sistema lo que determina mayores eficiencias globales.

A su vez, debemos tener en cuenta que durante el otoño han sido detectadas disminuciones importantes en la tasa de crecimiento o ganancias de peso de los corderos en pastoreo, aún en condiciones de alimentación sin restricciones (Banchero y col., 2006). Más allá de reconocer la necesidad de encontrar las causas de estos efectos y sus posibles soluciones, este hecho señala la conveniencia de extraer los corderos del sistema antes del otoño para evitar transitar con cargas elevadas por los momentos de menores eficiencias de conversión.

La utilización de cruzamientos terminales tiene como principal efecto el incremento en la velocidad de crecimiento (Cuadro 2), pre y post-destete, y por tanto permite capitalizar una de las mayores virtudes de la especie ovina (sus ciclos productivos cortos).

El sistema 3 de acuerdo a la información obtenida en este estudio presenta un IF que supera en un $46 \%$ al del sistema 1 . Este mejor resultado económico está sustentado en un incremento de la carga (10 vs 7,9 ovejas/ha) que logra obtenerse por el hecho de vender los corderos más temprano y antes del otoño. Esta mayor carga determina una mayor producción de lana por unidad de superficie y mayor cantidad de $\mathrm{kg}$ de peso vivo de cordero producidos.

El sistema 4 presenta como incorporación, respecto a los tres sistemas evaluados anteriormente, la utilización de biotipos maternales de mayor prolificidad y habilidad materna como base de cría. A su vez, debe- 
mos tener en cuenta que estos materiales genéticos en las mismas condiciones de recría que las razas laneras, con las cuales se les ha comparado, presentan un PV adulto aproximadamente $6 \mathrm{~kg}$ superior a las de estas últimas (Cuadro 2). Esto podría sugerir a priori, que la capacidad de carga debería disminuir con respecto al sistema 1 . Sin embargo, la mayor velocidad de crecimiento de los corderos hijos de biotipos maternales y cruzamientos terminales (Cuadro 2), determina que el tiempo necesario para alcanzar el peso previsto de faena sea mucho menor y por tanto reduce la permanencia de los corderos en el sistema y aumenta el espacio forrajero para las ovejas. Esta mayor velocidad de crecimiento se obtiene a partir de una combinación de factores: mejor habilidad materna y producción de leche de los biotipos maternales y la mayor tasa de crecimiento por efecto de heterosis simple y efecto aditivo de las razas terminales.

A su vez el principal efecto de la utilización de biotipos maternales es su mayor tasa ovulatoria (Cuadro 2) y por tanto un mayor número de corderos nacidos. Con un criterio similar al señalado con anterioridad, cuanto mayor sea la cantidad de $\mathrm{kg}$ de peso vivo de cordero producidos por una oveja a lo largo de un ciclo productivo, el alimento destinado al mantenimiento de la oveja a lo largo de todo el año se diluye entre un mayor número de $\mathrm{kg}$ de peso vivo de cordero, aumentando por tanto la eficiencia global del sistema.

El sistema 4 como consecuencia de su mayor prolificidad y habilidad lechera aumenta la producción de peso vivo por unidad de superficie en un $96 \%$ y los IF en un $132 \%$ con respecto al sistema 1 , que es utilizado como base de comparación.

En el sistema 5 se incorpora la encarnerada de corderas en su primer otoño de vida (Cuadro 2), a los efectos de cuantificar el impacto de la precocidad sexual característica de los biotipos maternales, sobre la eficiencia del Sistema productivo pastoril.

Una vez más, el aprovechamiento de la precocidad sexual de estos biotipos diluye los costos de mantenimiento en la alimentación, en la medida que se evita mantener categorías improductivas en el sistema debido a que las corderas comienzan a producir en su primer año de vida. La utilización de la precocidad sexual de los biotipos especializados en esta condición (FM y sus cruzas) permitió un incremento del IF un 11\% del sistema 5 con respecto al Sistema 4 y el aprovechamiento de todos los beneficios de los biotipos maternales (prolificidad, habilidad materna y precocidad sexual) permitió un incremento del $159 \%$ en el IF, tal cual se ve reflejado en las diferencias entre el sistema 1 y el sistema 5. (Cuadro 5).

Si bien no ha sido cuantificado en el presente trabajo, la precocidad sexual permitiría también en explotaciones que prioricen la mejora genética aumentar el Progreso Genético Anual (PGA) en la medida que el Intervalo Generacional (IG) puede reducirse, en la medida que el promedio de edad podría pasar de 4 a 3 años en las hembras y de 3 a 2 años en los machos, dependiendo del manejo del sistema.

\section{CONCLUSIONES}

La utilización de biotipos maternales y cruzamientos terminales permite incrementar la productividad y en forma proporcional los ingresos familiares en sistemas ovejeros orientados a la producción de corderos en ciclos completo.

Estas mejoras pueden atribuirse a una mejor eficiencia derivada del aprovechamiento de las principales virtudes de la especie ovina: precocidad sexual, partos múltiples, ciclos productivos cortos, los que determinan que los costos metabólicos de mantenimiento para la etapa de cría disminuyan en forma relativa.

\section{AGRADECIMIENTOS}

El presente trabajo reúne información, registros y parámetros generados durante más de treinta años en el CIAAB e INIA en Sistemas Intensivos de Producción Ovina, en experimentos, modelos físicos y evaluaciones en condiciones pastoriles. En el transcurso de este tiempo han participado en las 
actividades un gran número de operarios, asistentes, técnicos y estudiantes. Su dedicación y esfuerzo han hecho posible el desarrollo del mismo.

\section{BIBLIOGRAFÍA}

BANCHERO, G.; GANZÁBAL, A.; FERNÁNDEZ, M.E.; ARES, V.; Y VAZ MARTINS, D. 2006. Bajas ganancias en otoño: una brecha importante para el ciclo de engorde de corderos. Revista del Plan Agropecuario, 117: 34-37.

CASTRO, E.; GANZÁBAL, A. 1988. Sistemas Lanares Intensivos. La Estanzuela, Uruguay. CIAAB. Estación Experimental La Estanzuela. Miscelánea $N^{\circ} 66.35 p$.

CASTRO, E.; GANZÁBAL, A.; CLARIGET, J.; COLUCCI, P. 1988. Sistema Lanar Intensivo, Unidad Experimental de Ovinos. La Estanzuela, Uruguay. Revista Argentina de Producción animal. 8 (2):169-181.

GANZÁBAL, A. 1988. Sistemas Lanares Intensivos. Estación Experimental La Estanzuela. Anuario de la Sociedad de Criadores de Corriedale del Uruguay. 45: 28-29.

GANZÁBAL, A. 1997. Alimentación de ovinos sobre pasturas sembradas. INIA. Estación Experimental Las Brujas. Uruguay. Serie Técnica Nro. 84.

GANZÁBAL, A.; MONTOSSI, F.; BANCHERO, G.: SAN JULIAN, R.; Y DE BARBIERI, I. 2001. Producción ovina intensiva La experiencia de INIA. En: Sistemas ovinos intensivos del litoral sur del Uruguay: enfoques de la investigación, la transferencia de tecnología y la producción. Boletín de Divulgación № 78. INIA. Agosto 2001.

GANZÁBAL, A.; RUGGIA, A.; DE MIQUELERENA, J. 2003. Producción de corderos en Sistemas intensivos. Jornada de Producción Ovina Intensiva. Serie de Actividades de Difusión No 342. INIA La Estanzuela. Noviembre 2003.

GANZÁBAL, A. 2005 Análisis de registros reproductivos en ovejas Corriedale pág. 69. Seminario de actualización técnica: Reproducción ovina. Abril-Mayo de 2005.

GANZÁBAL, A.; MONTOSSI, F.; CIAPPESONI, G.; BANCHERO, G.; RAVAGNOLO, O.; SAN JULIÁN, R.; LUZARDO S. 2007. Cruzamientos para la producción de carne ovina de calidad. Serie Técnica $\mathrm{N}^{\circ}$ 170, INIA, Noviembre de 2007. ISBN 978-9974-38-244-2.

GANZÁBAL, A.; CIAPPESONI G.; BANCHERO, G.; VAZQUEZ A. 2011. Biotipos maternales para enfrentar los nuevos desafíos de la producción ovina moderna. Congreso de Buiatría. Paysandú Uruguay. Junio de 2011.

GANZÁBAL, A.; BANCHERO, G.; VÁZQUEZ, A.; RAVAGNOLO, O.; CIAPPESONI, G. 2013. Evaluación del desempeño reproductivo de biotipos de media y elevada prolificidad en Uruguay. Congreso ALPA, Cuba. 
ESTRATEGIAS PRODUCTIVAS Y SU

IMPACTO ECONÓMICO EN SISTEMAS

DE PRODUCCIÓN DE CARNE OVINA DE

INTENSIFICACIÓN VARIABLE

\author{
J. I. Buffa ${ }^{1}$
}

J. Mondelli

\title{
RESUMEN
}

\begin{abstract}
El movimiento CREA realiza todos los años un análisis de los resultados físicos y económicos de las empresas CREA. Esto posibilita entre otras cosas brindar elementos a los diferentes agentes vinculados al sector agropecuario para la toma de decisiones con un mayor grado de información. Las empresas CREA ganaderas de la zona de basalto son en las que los ovinos tienen una mayor importancia en relación a las ubicadas en el centro y noreste del país. Los resultados del ejercicio dan cuenta que el ingreso de capital disminuyó $21 \%$ en relación al ejercicio 2011/2012. El componente ovino para estas empresas en el ejercicio, fue responsable de un $21 \%$ del Producto Bruto total. En empresas que sostenidamente han experimentado un resultado económico positivo luego de pagar renta por el campo, se destaca la importancia del rubro ovino en sus esquemas de producción. Se analizaron 2 situaciones concretas que enfrentan los sistemas de producción, mediante la utilización de una herramienta desarrollada por FUCREA e INIA denominada modelos de decisión. Por un lado se analizó para un sistema lanero la interacción entre el \% de señalada - precio de la lana con el sistema de producción ovino. Por otro lado se abordaron las posibilidades de dos estrategias de invernada de cordero: temprana (mayo) y tardía (octubre). Para la primera situación se constató que en sistemas de mayor eficiencia reproductiva tienen mayor estabilidad en la definición del propio sistema ante variaciones del precio de la lana. La segunda situación integró la evaluación de eficiencia biológica del sistema de invernada, estacionalidad de precio del cordero, concluyendo que la relación de precios que debe darse para que convenga vender el cordero tardío frente al temprano es de 1,11.
\end{abstract}

Palabras clave: ovinos, cordero pesado, modelos, rentabilidad, empresa, margen, ingreso de capital, precios

\section{INTRODUCCIÓN}

El Movimiento CREA realiza como todos los años un análisis de los resultados físicos y económicos de las empresas CREA. El objetivo de este tipo de instancias es aportar elementos a los diferentes agentes vinculados con el sector agropecuario, con elementos para la toma de decisiones con un mayor grado de información. La información generada para estas instancias permite en- tre otros, profundizar en análisis por rubro o de algunas realidades particulares de las empresas. En este sentido y en ocasión del Seminario Ovino organizado por el Instituto Nacional de Investigación Agropecuaria (INIA) se procedió a realizar un análisis de la situación del rubro ovino en los productores CREA. La primera pregunta que nos planteamos para analizar este aspecto fue: ¿dónde es relevante el rubro ovino en el Movimiento CREA? Se procedió a realizar algunos

\footnotetext{
${ }^{1}$ Ing. Agr. Coordinador Ganadero y Agrícola-Ganadero de FUCREA.

${ }^{2}$ Ing. Agr. Integrante del Equipo técnico Sectorial Ganadera y Agrícola-Ganadera de FUCREA.
} 


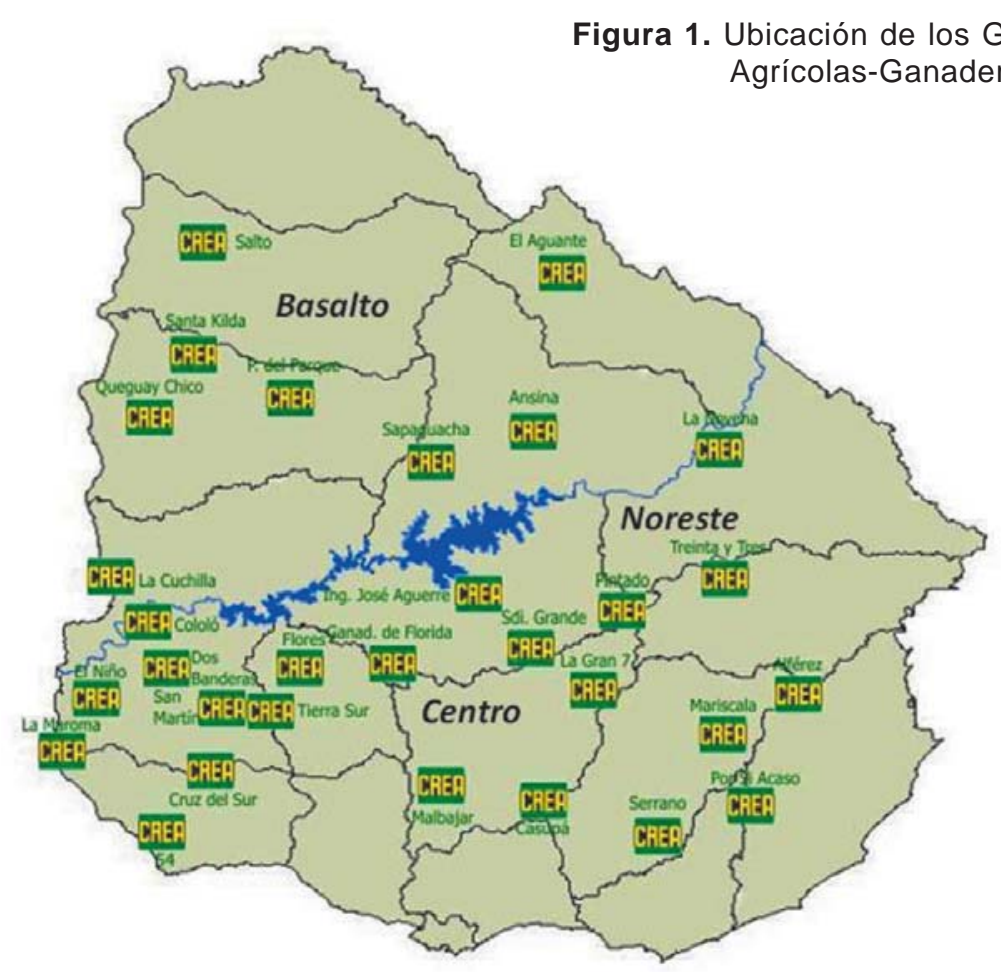

Cuadro 1. Indicadores Ovinos para los Grupos CREA por región.

\begin{tabular}{|l|c|c|c|}
\hline & Basalto & Noreste & Centro \\
\hline \% PB Ovino & $22 \%$ & $4 \%$ & $6 \%$ \\
Relación L/V & 1,5 & 0,38 & 0,53 \\
Carga Ovina (UG/ha) & 0,18 & 0,07 & 0,09 \\
\hline
\end{tabular}

indicadores para cuantificar la importancia del rubro ovino para tres zonas definidas (Basalto, Centro y Noreste). Se presenta la Figura 1 con la ubicación de los grupos CREA y en el Cuadro 1, los indicadores mencionados.

Como se puede apreciar en el Cuadro 1 , los indicadores dimensionan la mayor importancia que tienen los ovinos para las empresas CREA ubicadas en la zona de basalto, en relación a las ubicadas en el centro y noreste del país.

Debido a esto, el análisis se focalizará en el rubro ovino para la zona de basalto dada la importancia de este rubro en la citada zona. El propósito es analizar brevemente la realidad de este tipo de empresas poniendo foco en el componente ovino.
Una mirada a los resultados del ejercicio 2012-2013 para las empresas CREA de Basalto

En el Cuadro 2 se muestra el desempeño de las empresas para el ejercicio 2012/2013 las cuales lograron un ingreso de capital promedio de $88 \mathrm{U} \$ S /$ ha y una rentabilidad promedio de $2,4 \%$.

Los resultados del ejercicio estuvieron marcados por una caída en el resultado económico obtenido por estas empresas, donde el ingreso de capital disminuyó $21 \%$ en relación al ejercicio 2011/2012. La caída en el Ingreso de capital se explica por un incremento del $20 \%$ del valor de los costos de producción, y una muy leve caída del producto bruto. 
Cuadro 2. Resultados Gestión empresas CREA Basalto (Ejercicio 2012/2013).

\begin{tabular}{|lc|}
\hline Superficie utilizada (ha) & 2768 \\
Superficie Pastoreo (ha) & 2639 \\
PB (U\$S/ha superficie utilizada) & 204 \\
Insumos (U\$S/ha superficie utilizada) & 116 \\
\hline Ingreso de Capital & $\mathbf{8 8 , 2 6}$ \\
\hline Rel I/P & 0,57 \\
Activo & 3606 \\
Rentabilidad (\%) & 2,4 \\
\hline
\end{tabular}

La caída del producto bruto encierra comportamientos distintos en lo referente a vacunos y ovinos. Mientras la producción de carne vacuna $(\mathrm{kg} / \mathrm{ha})$ y el precio de la misma (U\$S/kg) mostraron aumentos respecto al año anterior, la carne ovina disminuyó su nivel productivo en un $10 \%$ y el precio un $30 \%$. En referencia a la producción de lana se registró un aumento de cerca del 10\%, en tanto el precio de la misma disminuyó en niveles cercanos a $30 \%$ respecto al año anterior.

El Producto Bruto Vacuno constituye unas 2/3 partes del Producto Bruto total (Figura 2).

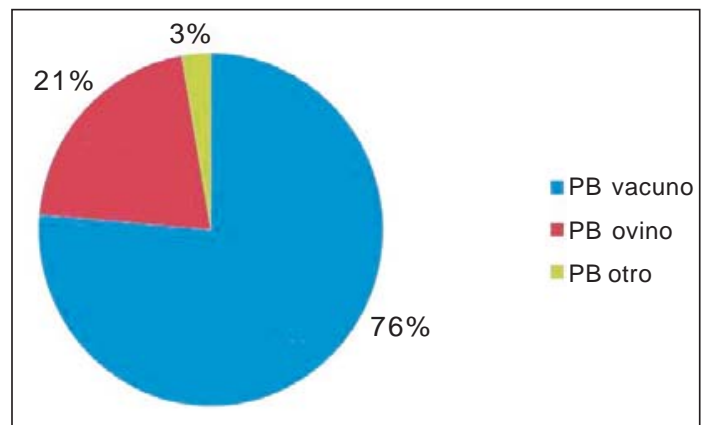

Figura 2. Composición del Producto Bruto para las empresas CREA de Basalto ejercicio 12/13.

Focalizando la mirada en el componente ovino de los sistemas, resulta relevante analizar el impacto tiene la producción física, tanto de carne como lana, en la determinación del producto bruto ovino.

En la Figura 3 se presenta la relación que hay entre la producción de lana y la producción de carne y lana en la determinación del Producto Bruto Ovino. Esta información fue obtenida a partir de los datos del ejercicio 2012/2013 con la producción de carne y la producción de lana.

Como primer comentario se desprende que existió una relación positiva entre la productividad física (carne y lana) y el producto

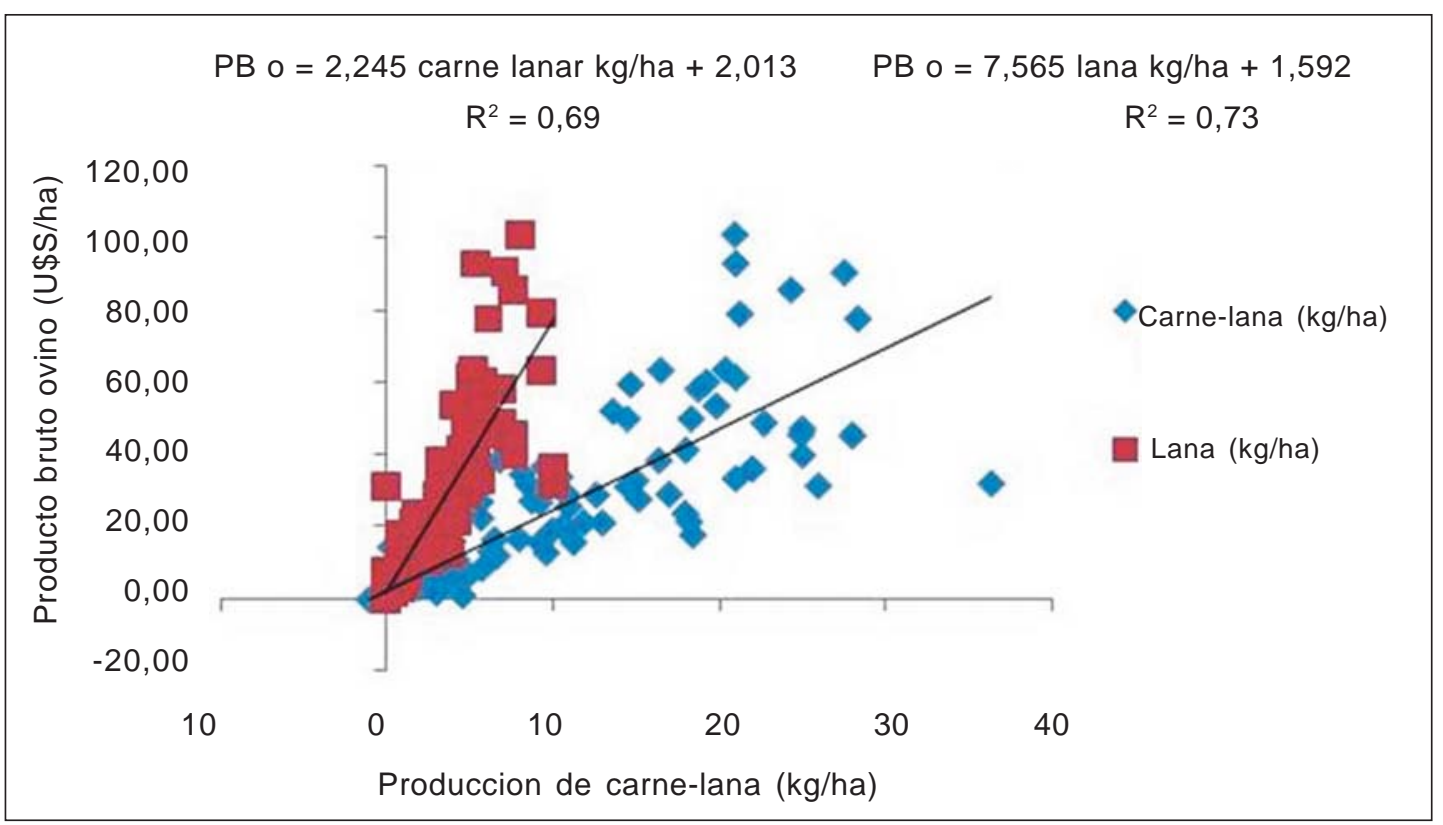

Figura 3. Correlaciones entre Producto Bruto ovino y Producción de Carne y Lana. 
bruto ovino. Un alto porcentaje de la variación del Producto Bruto Ovino está explicado por la variación de producción física tanto de carne como de lana.

\section{Analizando tres ejercicios para las empresas CREA de Basalto}

Conocido por todos es la variabilidad que tienen los precios y como afectan el desempeño del rubro ovino, por ello resulta relevante realizar un abordaje consolidando varios ejercicios. Para ello tomamos los resultados de las empresas CREA correspondiente a los últimos tres ejercicios y procedimos a realizar un análisis consolidado de la información.

El abordaje que se propone resulta en parte novedoso y consiste en analizar las empresas a través de la rentabilidad del negocio.

La dotación de Activos de una empresa agropecuaria, están conformados por la suma de todos los recursos valorizados sobre donde desarrollamos un determinado sistema de producción. Este capital está constituido en un $90 \%$ por la tierra y el resto lo conforma los vacunos, los ovinos y algunas partidas menores de activos.

El indicador de Rentabilidad se calcula conforme la siguiente fórmula:

Rentabilidad $\%=\frac{\text { Ingreso de capital }}{\text { Activo total involucrado }}$

Siendo el Ingreso de Capital = El producto Bruto total valorizado del sistema menos los costos del sistema. No se consideran dentro de la estructura de costo ni la renta ni los intereses.

Activo Total Involucrado $=$ refiere a la cuantificación del total de los activos involucrados en el proceso productivo.

Se propone «partir» esta rentabilidad en dos: la rentabilidad asociada a la tierra y la rentabilidad del «negocio». La rentabilidad asociada a la tierra la cuantificamos con la siguiente fórmula:
Por otro lado, se propone evaluar la rentabilidad asociada al «Negocio», conforme a la siguiente fórmula:

Rentabilidad Ingreso de Capital-Renta

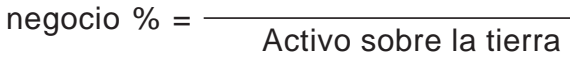

La rentabilidad del negocio, tal como lo muestra en la Figura 4, consiste en considerar un valor de renta que descontamos del Ingreso de Capital y relacionamos este valor con el activo involucrado "arriba de la tierra». Este esquema muestra como «partimos» la rentabilidad sectorial en estos dos componentes anteriormente descriptos.

El valor de renta considerado para cada ejercicio fue determinado para cada empresa en función del potencial productivo por parte de la Comisión de Asesores CREA. Con este enfoque es que se presenta a continuación un análisis en dónde se consolida la información para los tres últimos ejercicios.

La Figura 5 muestra el promedio de ingreso de capital para cada una de las empresas para los últimos tres ejercicios y se visualiza las veces que la rentabilidad del negocio fue positiva o negativa. En rojo tenemos registrada las veces que la rentabilidad del negocio fue negativa y en azul las positivas.

Se pueden diferenciar 4 grupos de empresas en base al resultado: aquellas que en los tres ejercicios la rentabilidad del negocio fue negativa (Figura 5), esto implica que a partir del ingreso de capital obtenido no pagan el valor de la renta. Otro grupo tiene un ciclo positivo y dos negativos, un tercer grupo conformado por las empresas que tienen dos ciclos positivos y uno negativo y el cuarto grupo de empresas que en los tres ejercicios logró tener rentabilidad positiva del negocio, esto es que alcanzaron pagar la renta y quedó un saldo disponible para remunerar los activos involucrados sobre la tierra.

\footnotetext{
Valor de la renta-Costos asociados a la tenencia de la tierra Rentabilidad tierra $\%=\frac{\text { Activo tierra }}{}$
} 


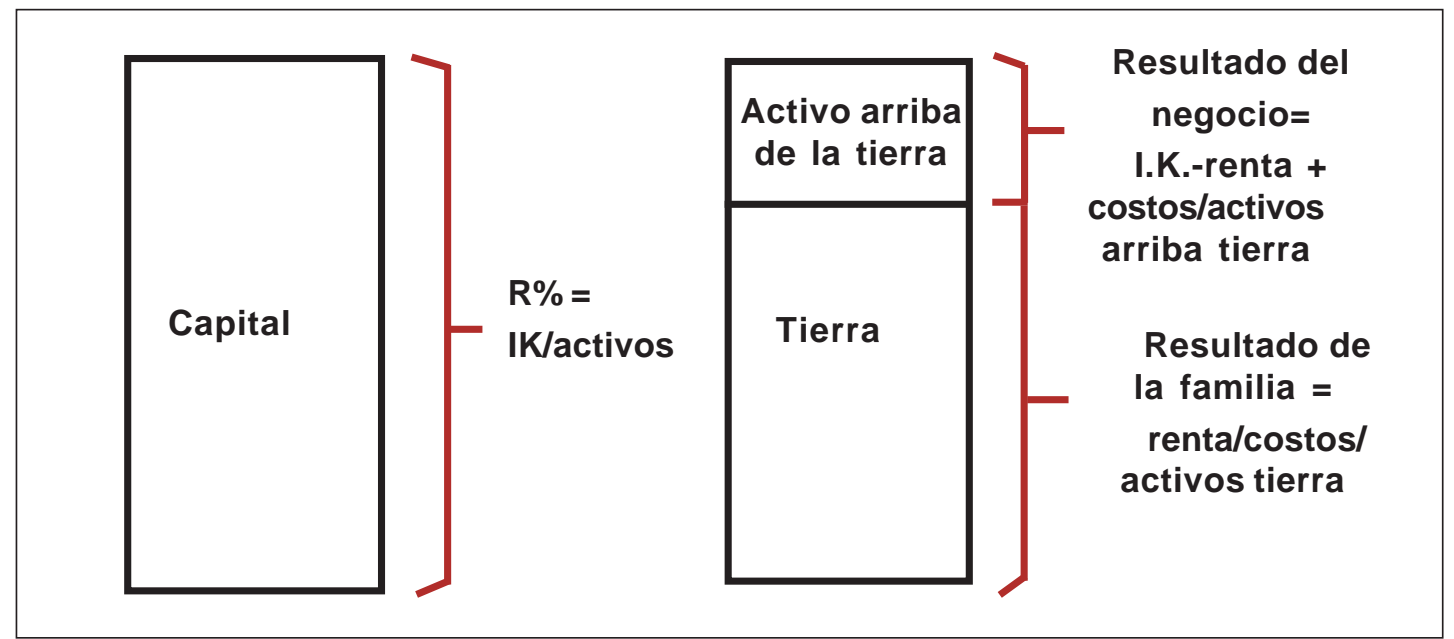

Figura 4. Partición de la rentabilidad Sectorial.

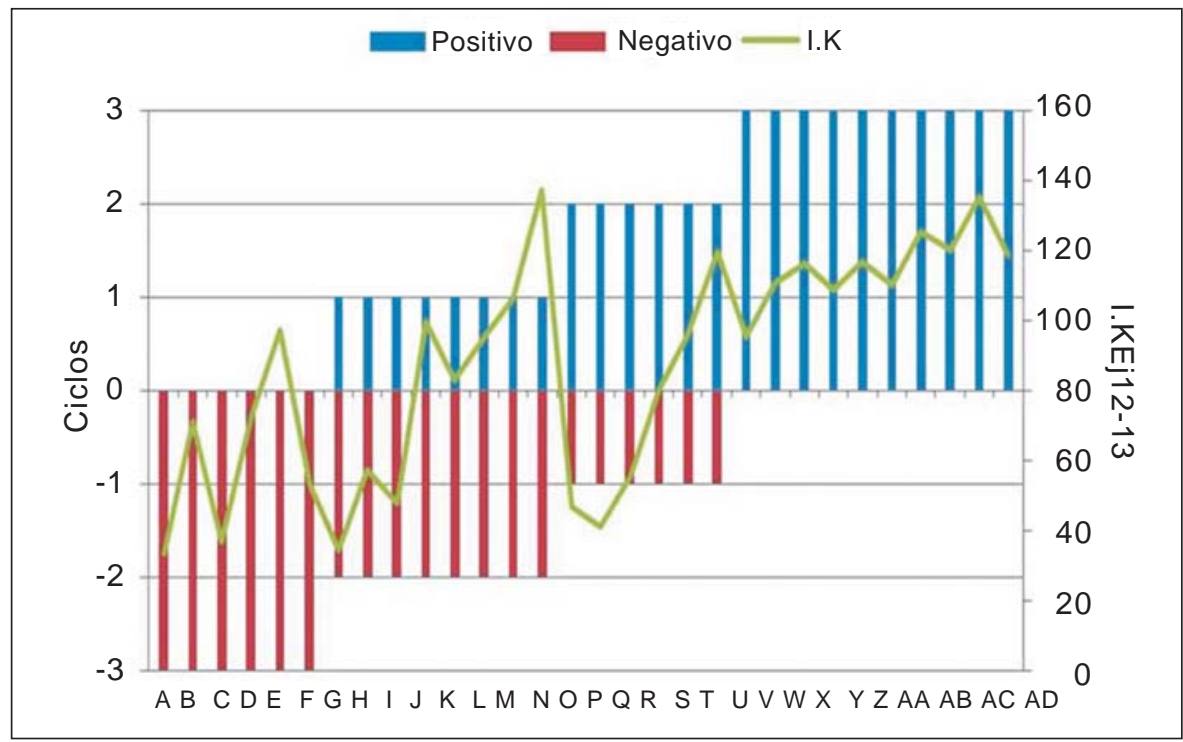

Figura 5. Empresas CREA Ganaderas Basalto según ciclos positivos o negativos de Rentabilidad.

Resulta interesante analizar algunos indicadores de este cuarto grupo de empresas, algunos de ellos se describen en el Cuadro 3.

Como se puede ver, estas empresas logran remunerar el activo tierra a un 3,3\% mientras que los activos que utilizan sobre la tierra, que son aquellos en que todos los años el productor decide poner en el sistema de producción, lo remuneran al 8,1\%.

Estas empresas lograron una producción de $73 \mathrm{~kg} / \mathrm{ha}$ de carne vacuna, $19 \mathrm{~kg} / \mathrm{ha}$ de carne ovina y $13 \mathrm{~kg}$ de lana equivalente lo que suma un total de $105 \mathrm{~kg}$ de carne equivalente por hectárea. La carga vacuna fue de 0,52 UG/ha y la carga ovina de 0,22 UG/ha. Estos indicadores físicos son el promedio de los últimos tres ejercicios para estas empresas con rentabilidad positiva en los tres ejercicios citados.

Vemos que estamos frente a empresas que tienen un nivel de diversificación con el ovino importante teniendo una relación L/V de 2,8 . Son empresas que tienen estructurado el rubro ovino en sus esquemas. 
Cuadro 3. Indicadores de Empresas CREA con 3 ciclos positivos de Rentabilidad.

\begin{tabular}{|lcc|}
\hline I.C & & 70 \\
SPG & ha & 2973 \\
\% Mej & $\%$ & 10 \\
PB Total & U\$S/ha & 209 \\
Insumos & U\$S/ha & 89 \\
I.K & U\$S/ha & 120 \\
Renta & U\$S/ha & 80 \\
Resultado Negocio & U\$S/ha & 40 \\
R\% Tierra & $\%$ & 3,3 \\
R\% Negocio & $\%$ & 8,1 \\
\hline
\end{tabular}

En la Figura 6 se muestra la composición del Producto Bruto Ovino para el promedio de los tres ejercicios para las empresas que logran remunerar la tierra.

Se puede apreciar que los ovinos constituyen $37 \%$ del producto bruto total de estas empresas confirmando la matriz diversificada de las mismas.

¿Por qué nos parece relevante este análisis? En primer lugar para saber si las empresas están pudiendo remunerar al principal factor de producción que es la tierra, esto es especialmente relevante en empresas que obviamente arriendan tierra pero lo es también para aquellas que no lo hacen. Creemos que diseñar sistemas productivos que logren remunerar los factores de producción es parte de la construcción de empresas sustentables. Pensemos que puede pasar en una empresa agropecuaria familiar en dónde esto no se logre, las posibilidades de no seguir como empresa se incrementan.

Hasta este punto hemos analizado los resultados de las empresas CREA para el último ejercicio y hemos realizado un análisis consolidado de los tres últimos ejercicios. A continuación, y considerando la realidad de estas empresas, analizaremos dos situaciones problema muy concretas que se presentan en los sistemas ovinos. Para realizar dicho abordaje se fijaron dos objetivos:

1) Analizar para un sistema lanero la interacción entre el \% de señalada - precio de la lana con el sistema de producción ovino.

2) Analizar dos estrategias de invernada de cordero: temprana (mayo) con tardía.

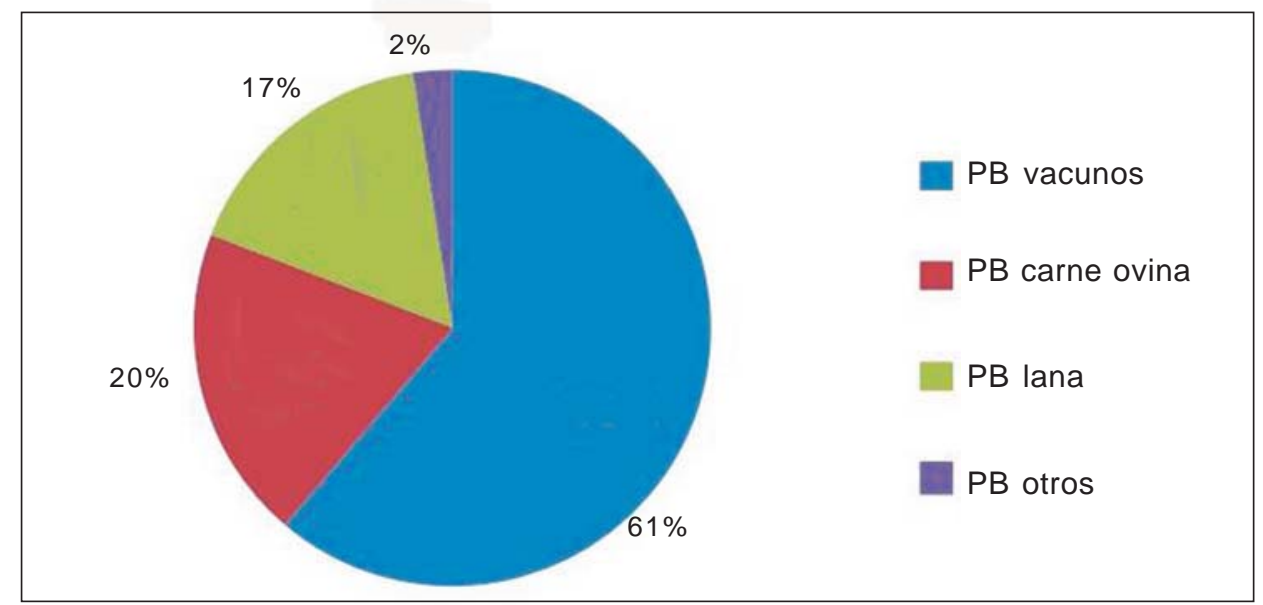

Figura 6. Composición del Producto Bruto para las empresas que logran remunerar la tierra. 
Para analizar las situaciones problema, utilizaremos una herramienta desarrollada por FUCREA denominada «Modelos de Decisión», que describiremos en el siguiente capítulo.

\section{MARCO METODOLÓGICO}

\section{Descripción de la herramienta utilizada}

Para la realización de este trabajo se utilizó un modelo de decisión llamado modelo «GANADERO-AGRICOLA». Dicho modelo fue desarrollado por técnicos vinculados a FUCREA en el marco de diversos proyectos con el Instituto Nacional de Investigación Agropecuaria.

FUCREA posee una rica historia en el análisis de los sistemas reales de producción. En este proceso se ha realizado especial hincapié en tres aspectos:

- La determinación de los objetivos y metas de la empresa y familia.

- El análisis de la historia y la situación actual de la empresa.

- El diagnóstico: analizando los desvíos entre la situación meta y la realidad de la empresa.

Los esfuerzos para determinar las vías para la solución de las problemáticas que se presentan en la empresa han sido también un tema de gran preocupación. En este sentido, además del análisis de las diferentes alternativas por parte de técnicos y del Grupo CREA, la realización de giras dentro o fuera del país, visitas a unidades experimentales de INIA y Facultad de Agronomía, visitas a establecimientos destacados en cuanto a los indicadores económicos y físicos o el desarrollo de los grupos GIPROCAR, constituyen una extensa lista de acciones que se han ejecutado dirigidas a levantar las limitantes de los sistemas de producción.

Sin lugar a dudas, estas acciones han repercutido en forma positiva en las empresas y les han permitido mejorar sustancialmente. No obstante, el desarrollo de herra- mientas que permitan definir sistemas de producción que habiliten el cumplimiento de los objetivos y metas de la empresa, se constituía en una necesidad importante por parte de distintos agentes vinculados al desarrollo predial.

Los métodos tradicionalmente usados para la evaluación de diferentes alternativas presentan algunas limitaciones, como por ejemplo:

- Evalúan un número muy limitado de actividades. La complejidad de los sistemas de producción (muchas variables e interacciones, entre sus variados componentes), determina que no se puede abordar su estudio con modelos simples.

- Ese número reducido de alternativas evaluadas y la nula o precaria medición del efecto de las interacciones, nos lleva a la selección de sistemas o alternativas de producción que no exploran el potencial económico. No siempre la actividad de mayor resultado económico, analizada aisladamente, integra la mejor combinación de actividades cuando se evalúa en el conjunto del sistema de producción.

Las limitantes de los métodos simples normalmente utilizados se expresan en su mayor magnitud cuando estamos analizando sistemas de producción que se sostienen sobre ambientes de alto potencial productivo (lo que lleva implícito un menú importante de opciones); o cuando el sistema actual de producción está cercano a los potenciales productivos y económicos.

Según las especialistas Susana Pena de Ladaga y Ariadna Berger, «Un modelo consiste en una descripción simplificada de los componentes de un sistema y las interacciones de los mismos» $\left({ }^{1}\right)$.

Dentro de las características que presentan los modelos se puede destacar:

- Son una simplificación de la realidad.

- Permiten analizar una decisión en forma económica.

- Requieren menos tiempo para ver los efectos de las decisiones. 
- Permiten examinar cuestiones que es imposible ver en la realidad con anticipación.

- Permite ganar en conocimiento sobre un problema bajo estudio.

\section{Características generales del modelo}

La herramienta fue desarrollada en base a Microsoft Excel, como un conjunto de planillas interconectadas que permiten completar en una matriz dos tipos de información:

- Las actividades: la herramienta permite contemplar una amplia gama de actividades ganaderas, rotaciones forrajeras, rotaciones agrícolasforrajeras, rotaciones agrícolas, suplementación, transferencia de forraje, etc.

- Las restricciones: se deben completar las restricciones del sistema tales como el área total, mejorable y agrícola, balance forrajero, etc.

Esta herramienta, determina cuál es el sistema de producción (combinación de actividades) que maximiza el resultado económico (margen bruto o ingreso de capital), dentro de las opciones posibles en el marco de las restricciones planteadas (de índole técnico - biológico y/o aquellas restricciones de carácter empresarial). También podemos determinar los costos de oportunidad de los diferentes recursos y sensibilizar el sistema ante cambios en las relaciones de precios.

Dada la complejidad de los sistemas bioeconómicos, con su gran cantidad de componentes interrelaciones entre ellos, estos son muy difíciles de modelar, de forma que esta herramienta sólo pretende ser una representación simplificada de la realidad.

El resultado económico lo cuantifica como el margen sobre algunos costos especificados (pasturas, sanidad, suplementación); o como ingreso de capital (margen anterior menos el resto de los costos de la empresa).

La herramienta desarrollada permite ser adaptada a las particularidades de diferentes zonas, definiendo las distintas activida- des (rotaciones agrícolas y forrajeras, actividades ganaderas, etc.) y coeficientes técnicos acordes a las características de cada zona agroecológica a estudiar.

Una vez finalizado el ingreso de los diferentes coeficientes y precios, esta herramienta permite, además de determinar el sistema que maximiza el resultado, obtener un menú de sistemas de producción alternativos que maximizan el resultado económico para niveles variables de restricciones.

\section{Consideraciones metodológicas para dar respuesta a las situaciones problemas planteados}

El primer objetivo planteado es analizar para un sistema lanero la interacción entre el \% de señalada - precio de la lana con el sistema de producción ovino. Lo que pretendemos es analizar cuanto debería bajar el precio de la lana y cambiar el sistema de producción ante dos eficiencias reproductivas.

El segundo objetivo consiste en analizar el impacto económico por mejorar ganancia en la invernada de corderos comparando venderlo en Mayo frente a Octubre, considerando en este escenario la estacionalidad de precios que ocurren en el Uruguay.

En la Figura 7 se plantea la problemática que se pretende resolver en ambos objetivos.

Para el caso del sistema lanero exclusivamente a campo natural, se plantean 2 sistemas con distintas eficiencias reproductivas (70\% y $90 \%$ ) y se modificará el precio de venta de la lana. Se determinará el precio de la lana en cada uno de los sistemas que hace que la opción optima económicamente implique cambios en la orientación productiva (Venta de capones vs. Venta de corderos).

La intensificación de los sistemas se analizó mediante la realización de la invernada temprana y la invernada tardía sobre la base aun sistema con un $10 \%$ de mejoramientos. Se definió 2 momentos de venta (mayo y octubre) con dos eficiencias reproductivas 


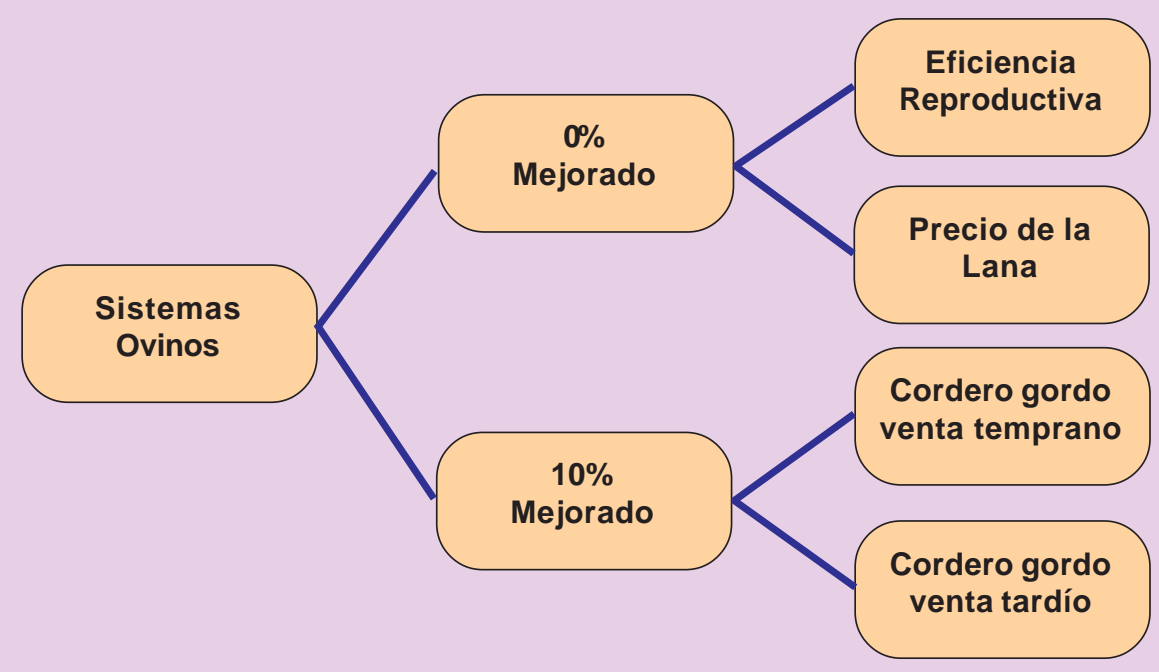

Figura 7. Planteo Metodológico.

(70\% y $90 \%$ ) lo que determino cuatro sistemas de producción. El modelo se alimentó con coeficientes técnicos de un peso al destete de $22 \mathrm{~kg}$, una ganancia diaria de $122 \mathrm{~g}$ y alimentación en base a pastura y granos para la venta en mayo y con $55 \mathrm{~g} /$ día y alimentación en Campo Natural y pradera para los corderos de venta en octubre.

Como supuestos se tomo una serie de precios de lana de 27-28 micras y un precio del cordero pesado en segunda balanza, tomada del Secretariado Uruguayo de la Lana (SUL).

\section{RESULTADOS}

\section{Pregunta 1 - Interacción precio de lana y sistema de producción}

Se definieron dos sistemas de producción con dos eficiencias reproductivas cuyas características e indicadores se presentan en el Cuadro 4.

Se trata de sistemas $100 \%$ de campo natural ambos sistemas presentan una orientación lanera con venta de capones a los 2 años con precio de lana de 3,03 U\$S/kg.

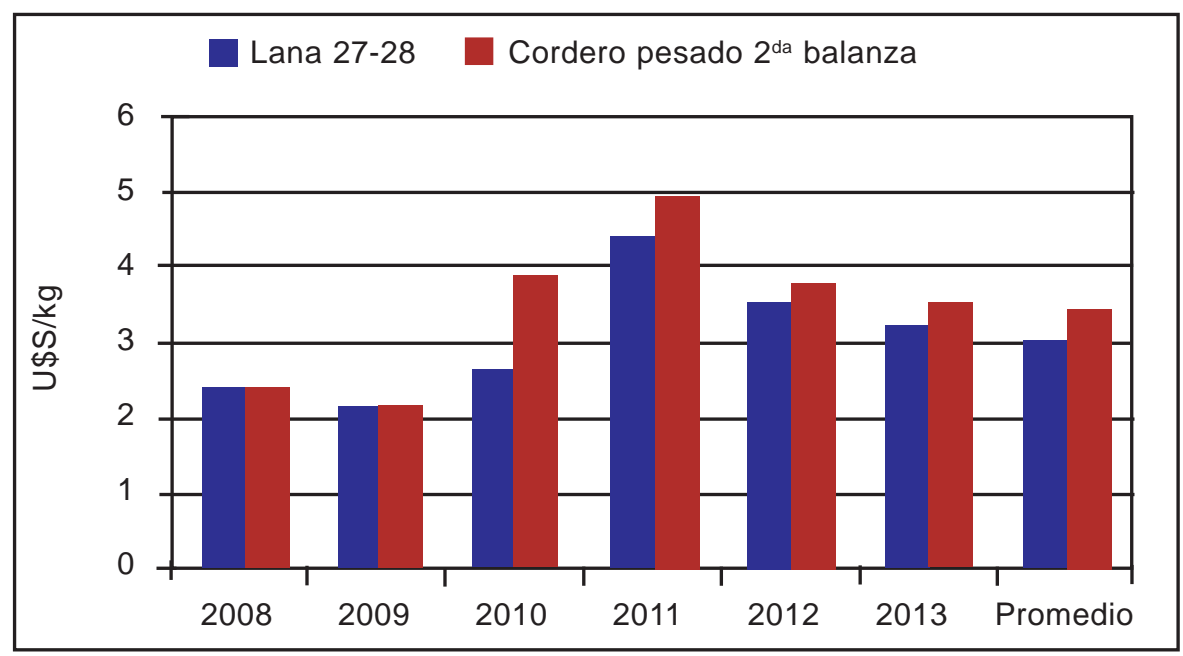

Figura 8. Serie de precios considerada para la Lana 27-28 micras y Cordero. Fuente: SUL. 
Cuadro 4. Características de los sistemas ovinos con 2 eficiencias reproductivas.

\begin{tabular}{|l|c|c|}
\hline Señalada & $\mathbf{7 0 \%}$ & $\mathbf{9 0 \%}$ \\
\hline Peso Oveja kg/cab. & 45 & 55 \\
Uso suelo & & \\
CN & $100 \%$ & $100 \%$ \\
Mejoramiento & $0 \%$ & $0 \%$ \\
Ovejas de Cría & 2125 & 1768 \\
Venta corderos destete & 0 & 0 \\
Venta capones 2 años y ovejas excedentes & 801 & 988 \\
Margen Bruto U\$S/ha & 113 & 124 \\
\hline
\end{tabular}

Al analizar dos eficiencias reproductivas diferentes, también consideramos una oveja «diferente» por lo que estamos asumiendo el «costo» que tiene esa mayor eficiencia reproductiva (Figura 9).

Al sensibilizar el precio de la lana, con un $10 \%$ de reducción del mismo el sistema con mayor eficiencia reproductiva cambia la venta de capones por venta de corderos al destete, en tanto el sistema con baja eficiencia reproductiva mantiene la estructura de capones hasta reducciones del $90 \%$ del precio inicial de la lana.
De la Figura 9 se concluye que la estabilidad de un sistema ante variaciones del precio de la lana depende de la eficiencia reproductiva, dicho de otra manera una de las maneras de tener sistemas que en cierta medida se «independicen» del precio de la lana es lograr eficiencias reproductivas altas en los esquemas ovinos.

\section{Pregunta 2: Venta de Cordero temprano/tardío}

La estrategia del momento de venta del cordero también es otro aspecto importante a definir en los sistemas y que fue abordado

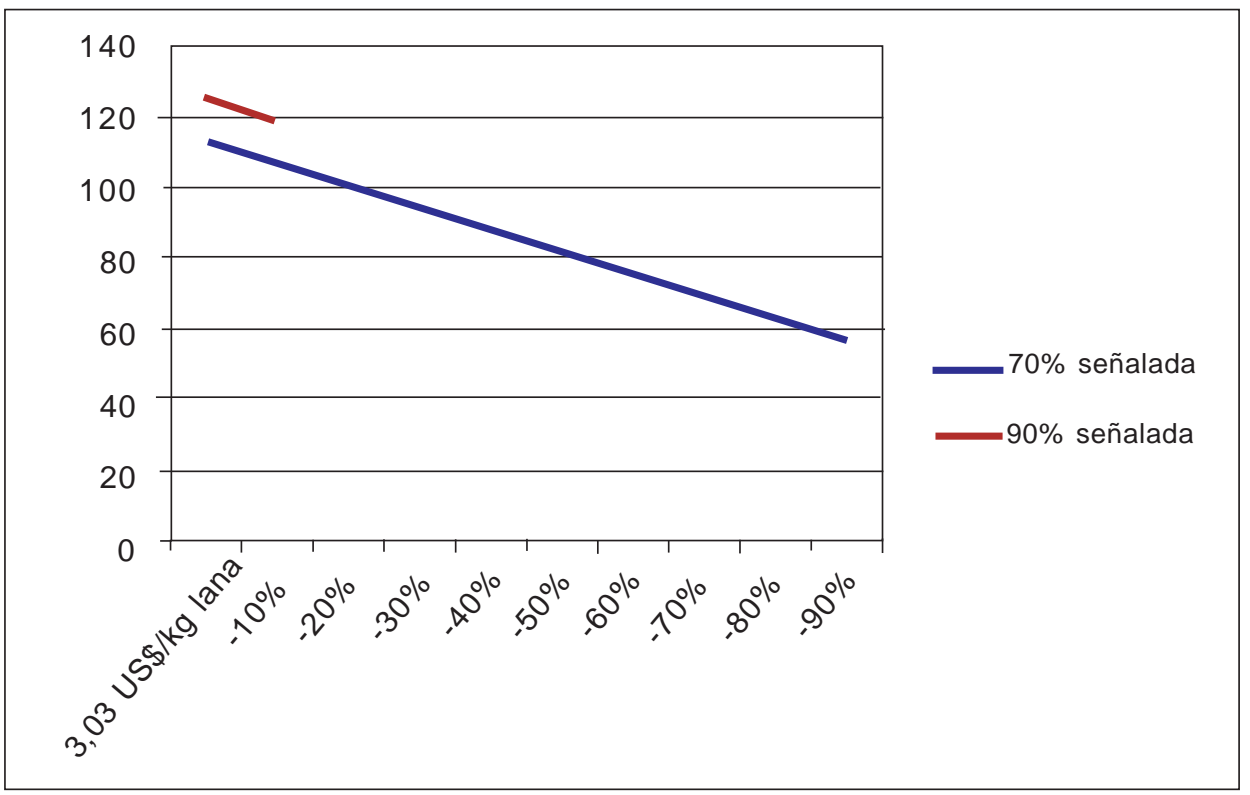

Figura 9. Porcentaje de reducción del precio de la lana para cambiar los sistemas a dos eficiencias reproductivas. 
con la herramienta del modelo. Un elemento importante y siempre discutido en este tipo de análisis es la consideración de la estacionalidad del precio del cordero. En el Uruguay ha existido una marcada estacionalidad que hace que los mejores precios se concentren hacia el segundo semestre del año (Figura 10).

En la Figura 10 vemos la estacionalidad del precio del cordero gordo considerando el período 2008-2013. Vemos que la estrategia de mayor eficiencia en la fase de invernadalo que implica vender el cordero en mayotiene un diferencial de precio de $5 \%$ menos que venderlo en octubre. Este diferencial de precio se considerará a la hora de realizar los análisis para contestar esta pregunta.

En el Cuadro 5 se presentan los resultados de cuatro planteos que resultan de considerar dos momentos de venta y dos eficiencias reproductivas:

Un primer aspecto que se destaca es que independientemente de la eficiencia reproductiva considerada, la definición de vender los corderos temprano implica ciertos cambios en la cantidad de ovejas que podrían ingresar en el sistema, la venta temprana de cordero y no tenerlos durante todo el am-

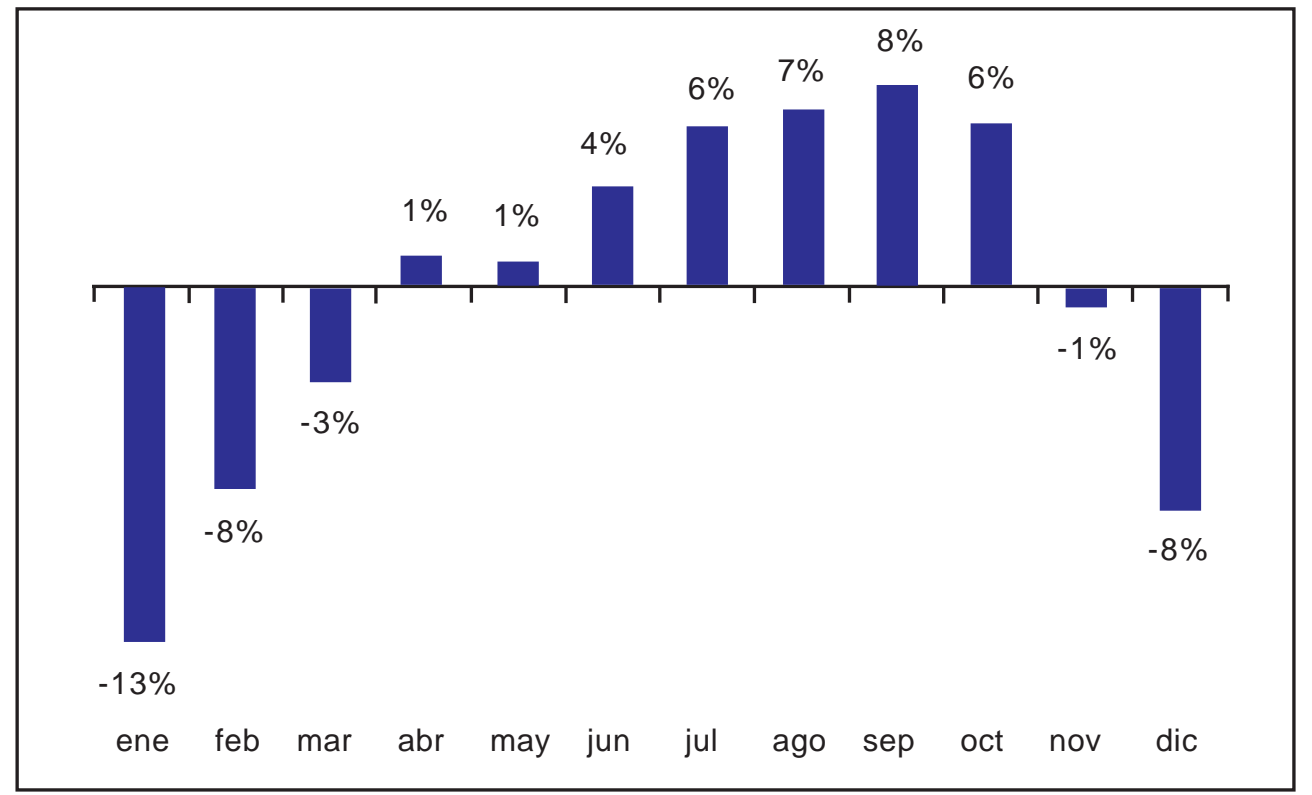

Figura 10. Estacionalidad del precio del cordero promedio entre 2008-2013.

Cuadro 5. Resultados de sistemas con venta de corderos en mayo y octubre.

\begin{tabular}{|c|c|c|c|c|}
\hline & $\begin{array}{c}\text { Venta cordero } \\
\text { Pesado } \\
\text { Invierno } \\
\end{array}$ & $\begin{array}{c}\text { Venta Cordero } \\
\text { Pesado } \\
\text { Primavera }\end{array}$ & $\begin{array}{c}\text { Venta cordero } \\
\text { Pesado } \\
\text { Invierno }\end{array}$ & $\begin{array}{c}\text { Venta Cordero } \\
\text { Pesado } \\
\text { Primavera }\end{array}$ \\
\hline Señalada & \multicolumn{2}{|c|}{$70 \%$} & \multicolumn{2}{|c|}{$90 \%$} \\
\hline \multirow[t]{2}{*}{ Margen Bruto U\$S/ha } & 145 & 142 & 167 & 163 \\
\hline & \multicolumn{4}{|c|}{ Uso del suelo } \\
\hline $\mathrm{CN}$ & \multicolumn{4}{|c|}{$90 \%$} \\
\hline Mejoramiento & \multicolumn{4}{|c|}{$10 \%$} \\
\hline Ovejas de Cría & 2919 & 2774 & 2643 & 2408 \\
\hline Venta Cordero Pesado mayo & 1161 & 0 & 1559 & 0 \\
\hline Venta Cordero Pesado octubre & 0 & 1103 & 0 & 1420 \\
\hline Grano/ha & 35 & 0 & 85 & 0 \\
\hline
\end{tabular}


biente posibilita aumentar la carga de ovejas en un $5 \%$. El mismo efecto se puede apreciar a las dos eficiencias reproductivas.

En definitiva, la venta temprana de corderos tiene un efecto negativo en cuanto precio, pero habilita y compensa parte de los resultados por tener una mayor carga de ovejas y por lo tanto, una mayor cantidad de corderos para vender. Cabe aclarar que en todos los sistemas la base forrajera es la misma y lo único que cambia es el nivel de suplementación de los sistemas.

Lo que se puede observar del Cuadro 5 que con la estacionalidad considerada de precio los resultados son casi iguales para las dos estrategias de venta temprana o tardía.

Un aspecto que resulta interesante es determinar qué relación de precio hace que se logre el equilibrio para la venta de corderos en octubre y mayo. La relación de equilibrio que hace indiferente vender en octubre vs mayo es de 1,11 esto implica que cuando tenemos una relación mayor que la mencionada es conveniente en términos económicos definir un sistema que venda los corderos en forma tardía.

En la Figura 11 se muestra como ha sido la relación de precios entre estos dos momentos.

\section{CONSIDERACIONES FINALES}

Un primer aspecto a destacar es la generación de ámbitos plurales para discutir las vías de mejora y desarrollo del rubro ovino.

La información presentada tiene dos grandes capítulos: a) los resultados obtenidos a partir de los resultados de Gestión de los CREA Ganaderos, b) los resultados obtenidos a partir de herramientas que proporcionan elementos a la toma de decisiones como son los modelos.

Desde los resultados de Gestión se pueden destacar los siguientes aspectos:

- El rubro ovino tiene una importancia económica importante en la zona norte del país.

- Para el ejercicio 2012/2013 el Producto Bruto Ovino constituyó el $21 \%$ del Producto Bruto total.

- Sistemas que logran remunerar la tierra tienen una matriz más diversificada y balanceada entre vacunos y ovinos.

Con respecto a las dos preguntas planteadas

- Interacción entre el \% de señalada precio de la lana: se constató que uno de los mecanismos de tener sistemas que en cierta medida se «independi-

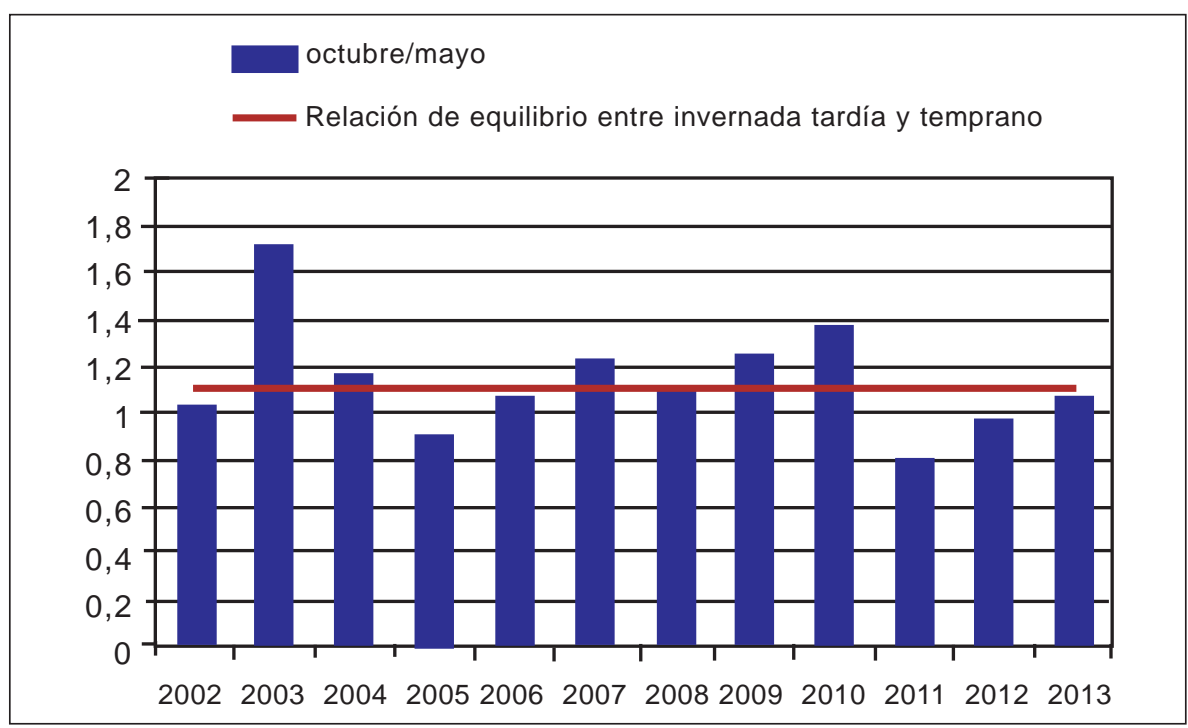

Figura 11. Evolución reciente de la relación entre el precio del cordero en octubre y el precio del cordero en mayo. 
cen» del precio de la lana, es lograr eficiencias reproductivas altas en los esquemas ovinos.

- La segunda pregunta consistió en analizar la interacción momento de venta - eficiencia biológica en las inverna- das de corderos: se cuantificó la relación de precio equilibrio a partir de la cual es conveniente definir una venta en octubre frente a mayo y la misma es 1,11 . 
